\title{
Energy efficient building
}

Rode, Carsten; Iversen, Anne; Pedersen, Anne; Villumsen, Arne

Publication date:

2005

Document Version

Publisher's PDF, also known as Version of record

Link back to DTU Orbit

\section{Citation (APA):}

Rode, C., Iversen, A. (Ed.), Pedersen, A. (Ed.), \& Villumsen, A. (2005). Energy efficient building. Byg Rapport No. R-115 http://www4.byg.dtu.dk/publications/rapporter/byg-r115.pdf

\section{General rights}

Copyright and moral rights for the publications made accessible in the public portal are retained by the authors and/or other copyright owners and it is a condition of accessing publications that users recognise and abide by the legal requirements associated with these rights.

- Users may download and print one copy of any publication from the public portal for the purpose of private study or research.

- You may not further distribute the material or use it for any profit-making activity or commercial gain

- You may freely distribute the URL identifying the publication in the public portal

If you believe that this document breaches copyright please contact us providing details, and we will remove access to the work immediately and investigate your claim 


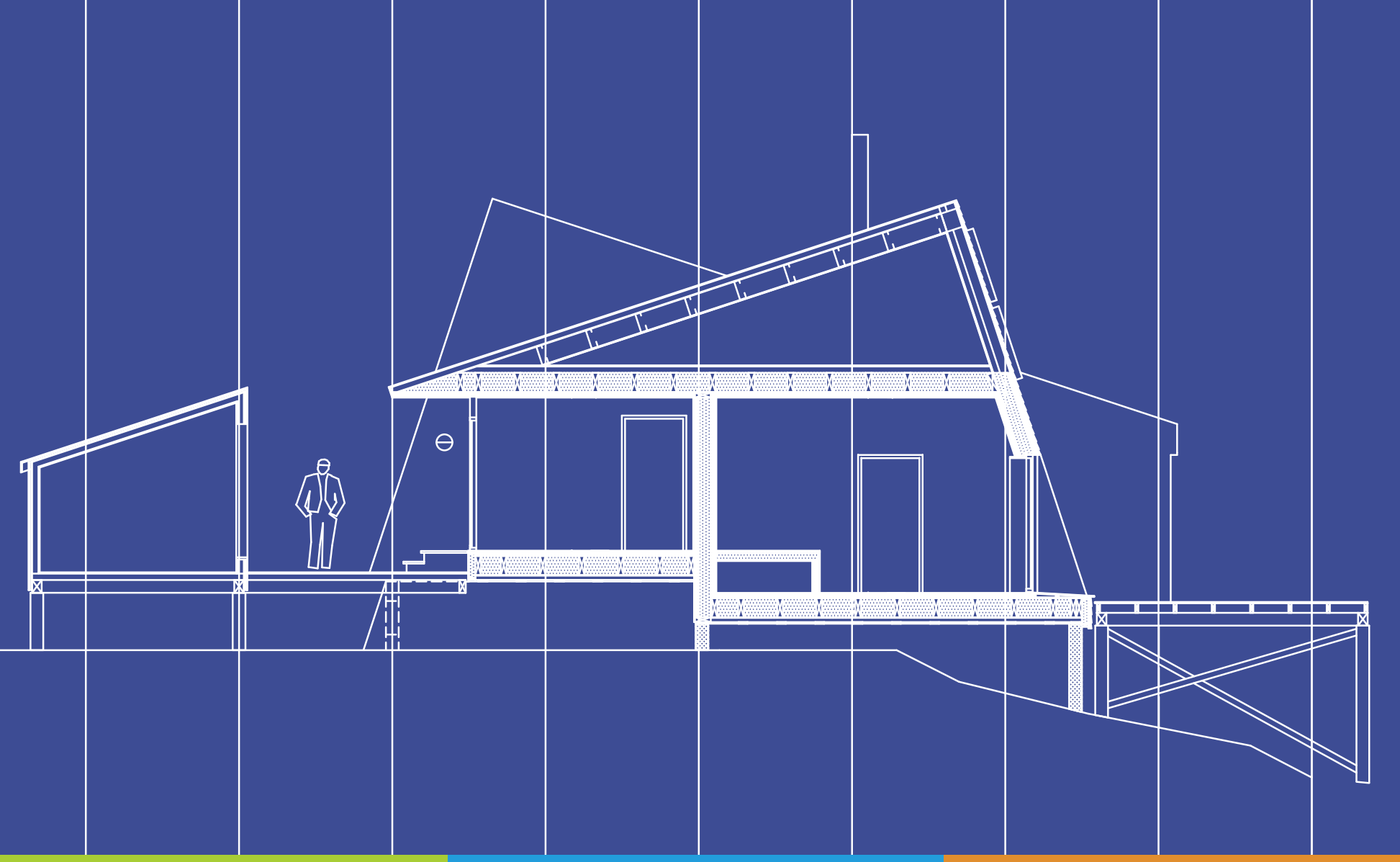

\section{Nukissamik atuiffiulluartumik sanaartorneq}

12.-14. april 05 • Sisimiuni isumasiogatigiinneq

\section{Energy-efficient building}

April 12th - 14th 2005 - Symposium in Sisimiut

\section{Artek Event}


Proceedings from the Symposium on Energy-efficient building,

April $12-14,2005$, Sisimiut, Greenland.

Symposium to celebrate the inauguration of the low energy house

in Sisimiut, built with support from The Villum Kann Rasmussen Fonden.

The symposium is granted by

Det Kongelige Grønlandsfond

and Kunaronden

Edited March-April 2005 by

Carsten Rode, Anne Iversen, Anne Pedersen and Arne Villumsen

Technical University of Denmark

Cover by Punkt@Prikke a/s

www.prikke.dk

ISBN=87-7877-183-8

\section{Report R-115}

Department of Civil Engineering, Technical University of Denmark www.byg.dtu.dk 


\section{Table of Contents}

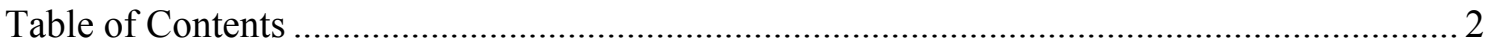

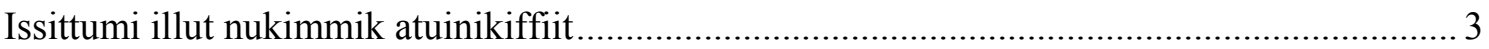

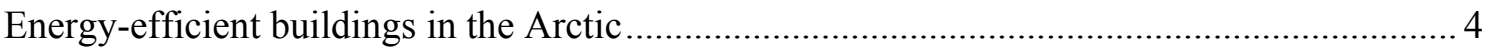

Local energy supply in the Arctic regions - and energy savings ......................................... 5

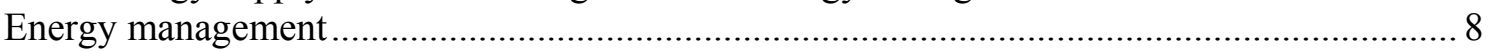

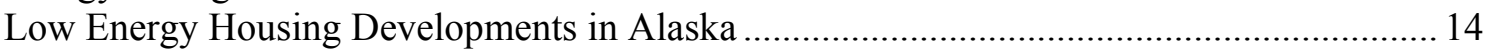

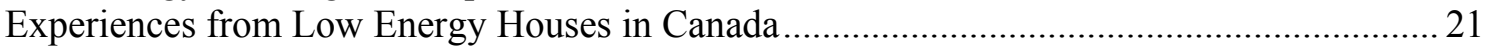

Advanced buildings in Iceland - different natural forces and resources ................................ 31

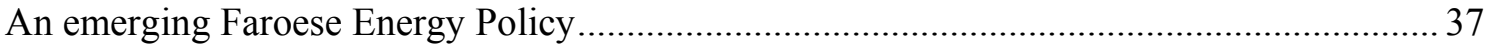

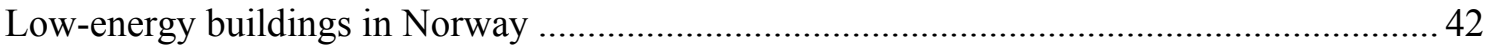

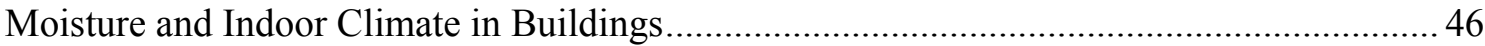

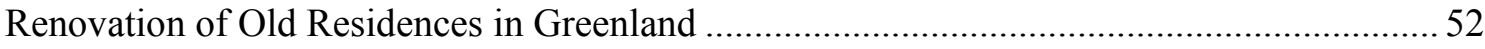

Little Floors Town-Planning Complexes with Energy Protect Building

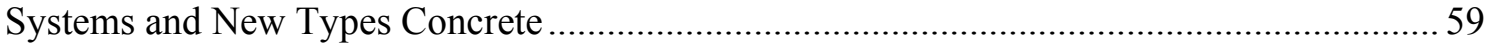

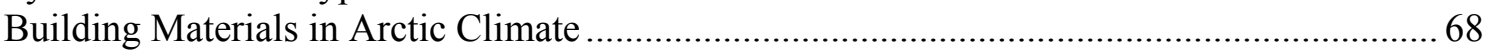

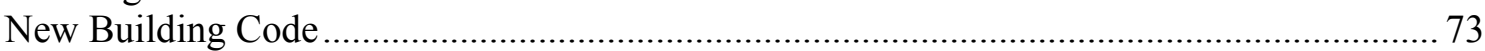

Holistic design with focus on structural functions and thermal bridges ................................ 79

The Low Energy House - Background, Accomplishment and Description of the Building ... 84

The Low Energy House - Facts and Technical Description of the Building ......................... 86

Energy performance of the low-energy house in Greenland.............................................. 88

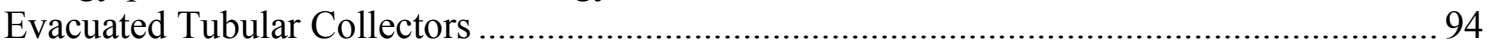

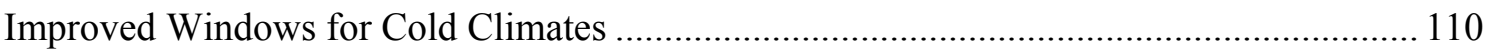

Mechanical ventilation systems with heat recovery in arctic climate .................................. 119

Solar Energy for Domestic Hot Water: Case Studies in Sisimiut ........................................ 124

Description of wind resource measurements at Sarfannguaq and general reflections

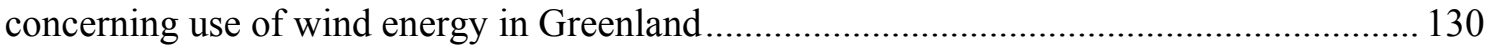

Individual heat metering attitudes to consumption of resources....................................... 135

Water, Heat and Power Supply of Houses in Greenland - the Next 25 Years ...................... 140

How shall we Build and Live in the Arctic in the Future ................................................... 141 


\title{
Issittumi illut nukimmik atuinikiffiit
}

\author{
Allattoq Arne Villumsen
}

2005-imi aprilip qiteqqunnerani ullut pingasut Kalaallit Nunaanni ingerlatsiviusut eqqaamaneqassapput illut nutaat ataavartumillu nukissiornermik tunngaveqartut qitiutinneqarfiattut:

\section{Illu nukissamik atuinikiffiusoq}

Tamatumunnga tunngatillugu Sisimiuni ersarilluartoq tassaavoq illu ullut pingasut isumasioqatigiiffiusut ingerlaneranni atoqqaartinneqartoq. Illu taanna ARTEK-ip suliffiutigalugu misileraaffigaa, illup iluani silaannaap pissusaani uuttugassat assigiinngitsut ukiuni aggersuni ilisimatusarfigineqassallutik.

Illu Villum Kann Rasmussenip Aningaasaateqarfiata tapiissuteqarneratigut napparneqarpoq.

Aningaasaliinersi pillugu qujaniarnerput matumuuna apuukkumavarput!

Isumasioqatigiinnermi saqqummiussassat pilersaarutaatigut neriunarpoq sammisassat Issittumi nunat peqataatitaasa naapertuuttutut isigissaat saqqummiunneqassasut. Nuannaarutigaara ilisimatuut Issittumi nunaneersut tikilluaqqusinnaagakkit. Pisortatigoortumik saqqummiussisussatut allassimasut saqqummiinerisa saniatigut, neriuppunga peqataasut akornanni persuarsiutiginngikkaluarlugu oqaloqatigiinnerit nassatariumaaraat siunissami suleqatigiiffiusinnaasut pillugit isumaqatigiissuteqartoqarnera. Aammattaaq neriuutigaara politikerit, ilinniartut, sanaartornermik suliaqartut allallu Sisimiuni ulluni pingasuni peqataasut oqallinnerit pissarsiffigiumaaraat.

Tunngaviusumik isuma tunuliaqutaasoq tassaavoq Issittumi nukimmik atuinikiffiusumik illulioriaatsitigut sunniuteqarnissamik neriuut. Sunniutaasut taakkua siunissami takussaanerulernissaannut illit apeqqutaavutit!

Isumasioqatigiinnissamut tamassi tikilluaqquassi!

Arne Villumsen, professor

Pisortaq, ARTEK 


\title{
Energy-efficient buildings in the Arctic
}

\author{
By Arne Villumsen
}

The 3 days in mid-April 2005 will be remembered in Greenland as the period where focus was on a new and sustainable building-type:

\section{The Low Energy House}

A very visible thing in Sisimiut related to this topic is the building which was officially opened during the three days where the symposium took place. This house is ARTEK's working laboratory, where indoor climate parameters will be studied in the years to come.

The House was raised with economical support from The Villum Kann Rasmussen Foundation.

Please accept our best thanks for the donation!

The programme for the symposium will hopefully cover a number of topics which all the Arctic country representatives will find relevant. It is a pleasure to welcome researchers from the Arctic countries to the symposium. Besides the formal - oral - contributions from everybody who are on the speakers list I hope that the informal talks between people will lead to agreements on cooperation in the future. Further to this I hope that politicians, students, professional building people and others who have decided to share the three days in Sisimiut will contribute to the discussion.

The overall idea is to leave our marks in the interesting world of energy-efficient building in the Arctic. It is up to you to let the marks be visible in the future!

I welcome all of you to the symposium!

Arne Villumsen, professor

Director, Arctic Technology Centre (ARTEK) 


\section{Local energy supply in the Arctic regions - and energy savings}

Johan Lund Olsen, Minister

Department of Industry, Agriculture and Labour, e-mail: johan@gh.gl

(Speech rendered by Commissioner Margrethe Sørensen on behalf of the Minister)

\section{OPENING}

Welcome participants, guests and Center for Arctic Technology.

It is an honour to be given the task of opening this symposium. Johan Lund Olsen was looking forward to three interesting days with inspiring contributions from representatives from Greenland and from the guests who have travelled far in order to participate.

The low energy house here in Sisimiut will officially be opened tomorrow. The house is built by ARTEK thanks to a grant from The Villum Kann Rasmussen Fond. Hopefully this house will be of inspiration and be used as reference for future energy conditions in the Arctic.

Johan hopes that this symposium will strengthen the international collaboration about energy, since we are all facing the same problems.

\section{THE LOW ENERGY HOUSE}

It is necessary to revise the daily use of the consumers. Also something new has to happen regarding energy technology. The use of energy has to be reduced in order to meet the challenges of the future.

Energy savings is almost solely a preventive arrangement and the intent of a low energy house is to save energy.

Low energy houses aim to be cost efficient. They have to be built according to the principle of simplicity, and the houses have to make the best of the buildings components. First and foremost it is about reducing the energy loss instead of introducing the building to elements that supply energy.

In general energy and water savings can be regarded when houses and buildings are constructed. New houses can be built so they don't have the same heat consumption as a regular house. The primary solution is good insulation, advanced low energy windows and a ventilation system, which secures a good indoor climate and which makes the most of the outgoing air. The savings obtained by installation and the running of the houses, are expected to make up for the expenses to increased insulation and air tightness.

The low energy house is applied research at its best. The house will tell us about energy savings, so that it can become everybody's possession. The use of low energy will become greater by making low energy popular and thereby reduce the use of energy and the environmental problems. 
It is not enough to supervise technological progress. Greenland has to participate when possible and there has to be a foundation from which the performance can be prioritised.

The collective energy supply is very expensive due to geography and climate, but some expenses can be reduced by thinking about and building low energy houses. The houses ability to keep the supplied heat will have positive consequences for the economy as well as the environment.

It is about changing the way of working, living and changing propellants for transportation.

\section{ENERGY SOURCES}

Energy sources as crude oil, natural gas and coal cannot be recycled when used. Therefore we in the Arctic shall as well as the rest of the world adjust to other lasting energy sources, such as solar energy, wind power, hydropower and maybe hydrogen. That the world needs to adjust is supported by the alarming climate changes that are especially clear here in Greenland and the rest of the Arctic.

The use needs to be kept in check and great fluctuations can be subdued if we as a population become better at thinking and behaving in a more proper way when it comes to energy.

Idle running on the power stations has to be reduced, and the leftover heat form the power stations has to be used optimally. The wear and tear of the power- and water supply facilities has to be limited in order to give technical facilities the longest life-span possible. Investments to expansion of power- and water supply facilities can be postponed by saving the energy consumption.

Because of the scattered population it is not possible to connect towns and settlements with wires and conduits. Every community has to be able to resist breakdowns since it is not possible to receive electricity or water from another community. Therefore the energy supply is very expensive.

It is a good idea to have good daily habits and a conscious behaviour when it comes to energy- and water supply. In the long run this will help reducing the costs.

For the exploitation of solar and wind, information is the most conclusive basis in order to make a decision about investing in facilities, which make use of these energy sources.

The best basis is the data about hydropower. Hydropower is the most suitable sustainable source of energy to the public supply. Expansion with hydropower is dependent on an appropriate amount of nearby potentials by the larger communities. Some communities may have hydropower potentials, which can be used part of the year, and therefore focus is drawn to micro-hydropower facilities.

Hydrogen attracts a lot of attention these years, and hydropower, solar and wind are considered possibilities for the production of hydrogen. 


\section{INTERNATIONALLY}

Greenland's participation in pioneering Nordic, European and American collaborations with hydrogen and hydro-technology have high priority. Greenland has to participate actively and be on the map of the world. So far important cooperative agreements have been established with Iceland, Norway and the Faroe Islands. Greenland will soon be part in an agreement with USA and participate in projects financed by EU.

Finally Greenland shall be open for participation in future demonstration projects e.g. on technique and economics with production of hydrogen in small communities.

\section{ENVIRONMENT}

Today the energy supply all over the world is mainly based on fossil fuels and almost every human activity is extremely dependent on these. The world economy can thank the foundation of fossil fuels for its material progress but now it is slowly ruining us.

In Greenland and the rest of the Arctic where dramatic changes in the climate threaten our way of life it is especially noticed. Therefore the climate problem is considered a great global challenge and it is of great significance for the Arctic.

Greenland is facing new challenges due to increased energy consumption and global climate changes. Too much $\mathrm{CO}_{2}$ and other climate gasses are released into the atmosphere. This is risky in an Arctic area, which is ecologically vulnerable.

Politically we continue our efforts to reduce the release of the greenhouse gasses. Whether it is in the transport sector, the commercial life, building activities, the housekeeping or in the production facilities or the distributional net, effective means that can reduce the damaging emissions have to be taken into use.

With these words I declare the symposium open on behalf of Johan Lund Olsen. 


\title{
Energy management
}

\author{
Margrethe Sørensen \\ Ph.d. in sociology, Commissioner \\ Department of Industry, Agriculture and Labour Market \\ MAS@gh.gl margrethe@greennet.gl
}

\begin{abstract}
This contribution will discuss and relate to a number of management instruments, all applied in order to promote better energy economy and energy efficiency within the water and power supply sector. Reaching the desired ends and the financial gains depends on the individual's own initiative and commitment. In addition, there is a need for a strengthened political effort for a continuation of this perspective.
\end{abstract}

\section{INTRODUCTION}

The title of my contribution is but one concept: Energy management! This opens for several aspects and further levels of details concerning this concept. I am not able to cover all aspects and have chosen to focus on energy management from my level of experience, being on the borderline between national policy and the intimately related administration.

In other words, I will treat this subject on a general level and with a long-term view.

\section{HEAT - ENERGY}

Heat has always been a fundamental condition for being able to exist in this, at times, freezing country. No matter the shivering temperatures, mankind, animal and vegetation must have sufficient heat at the right times in order to sustain life in harmony. It seems as a banal phrase but heat is a vital form of energy.

The methods for producing heat and keeping warm have been through a massive development. From train-oil lamps, fur clothing and small well-insulated turf huts to electrical heating, space age clothing and large glass wool insulated wooden houses, to mention some examples of this development.

The development moves rapidly forward within heating. This concerns technology as well as the way society regulates this area.

I have deliberately chosen not to begin with a wide use of the term "energy", rather, I have deliberately chosen heat instead of electricity in this introduction. I am of the opinion that this should take up a larger part of our agenda, and therefore this choice.

Furthermore, I have let my thoughts revolve around an expectation that the low-energy house will provide many financial gains compared to heating economy in conventional buildings. I am especially pleased that this will be evaluated on basis of data.

\section{A FEW NUMBERS ON ENERGY CONSUMPTION IN GREENLAND}

Greenland annually consumes app. $2500 \mathrm{GWh}$ gross energy of which the majority is imported as gas oil. 
Fig. 1: Gross energy consumption in Greenland 2002

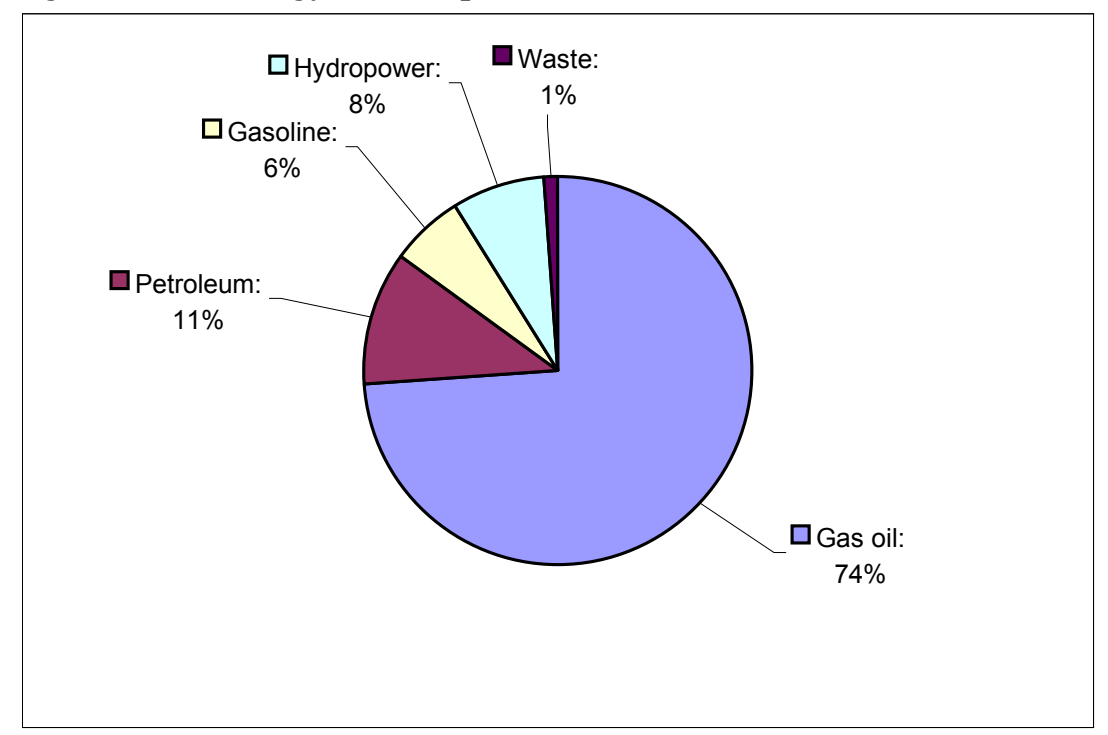

Source: Energiplan 2020 (not yet published)

Only small quantities of energy derive from own production mainly as hydropower and waste incineration.

The next figure shows how energy is consumed in the 18 towns and 59 settlements; in houses, fishing industry and transportation sector. As can be seen, the main bulk is used for heating. In the fishing industry and transportation sector energy is mainly used as propellants - and heating.

Heating has 5 times the size of electricity. 
Fig. 2: energy consumption in Greenland 2002

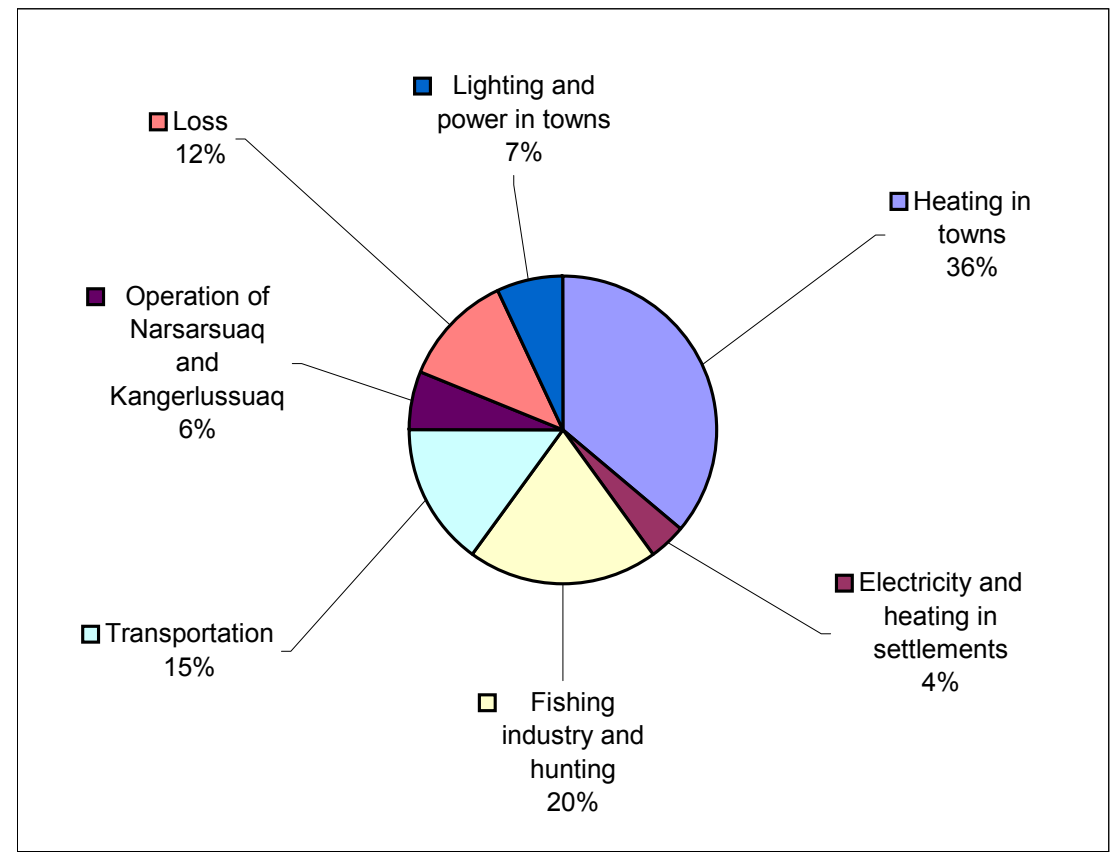

Source: Energiplan 2020 (not yet published)

Just to allow for another perspective we can look at the numbers of the largest town, Nuuk. Of the total energy production at the Buksefjorden hydropower plant $60 \%$ is used for heating in Nuuk. In addition, one must bear in mind that large quantities of gas oil are also used for heating in Nuuk.

\section{INCREASE IN CONSUMPTION}

Greenland would probably place itself somewhere between no. 10-15 on a scale of energy consumption per capita world wide. This, however, acts as a veil for enormous differences in energy consumption when we look at different communities and households.

Iceland holds the highest rate of energy consumption per capita. And, it is on the rise. The Icelanders have quite low expenses, since they practically speaking live on top of the energy. This makes heavy and energy-consuming industry possible as well as a rather impressive private consumption. Energy management and economics is not really an issue in Iceland.

Iceland is interesting since it shows what a plentiful supply of energy can entail, among other effects.

One of the preconditions of further economic development in Greenland, as in Iceland, is more production and more industry. This requires more energy.

On a national basis it is not relevant to speak of reduced or stagnating total energy consumption. On the contrary, a rise in consumption is desirable, since it can be expected to result from more commercial activity, a better and more modern information technologybased society and possibly higher standard of living.

The challenge for the immediate future is to secure that the rise in consumption takes the most economical and environmental desirable path possible. 
It is not possible to avoid a larger consumption of gas oil as well, when we are dealing with a rise in general consumption. A part of the rise in consumption must be brought about by means of renewable energy sources. A part of the current energy consumption of fossil fuels must be replaced by renewable sources.

The challenge for the following years is to limit, or - even better - to reduce the import of fossil fuels as much as possible. This can only come about if the individual consumer, the local communities, commercial life, transportation sector and the energy producers - in short: everyone - take part in the endeavours for managing energy consumption to the desired ends.

Greenland is to import fossil fuel for many years to come. In order to make this period as short as possible, and the quantities as low as possible, energy management is essential.

Simultaneously more impetus has to be put into the use of our own renewable energy sources. However, this issue resides outside the scope of my contribution here.

\section{MANAGEMENT TOOLS}

\section{Financial analyses}

All energy projects, be they low energy houses, hydropower plants, waste incineration facilities, heat pumps, wind mills or other energy projects should be valued economically in a satisfactory informational manner. Information on investment capital, operation, maintenance, expected lifetime, funding, etc. must be provided.

These figures should be substantiated to the extent that consumers, energy producers, local society and the entire society can get information on gains derived from a specific project. The chosen period of time must be taken in, since a difference in expectation of lifetime might make comparison between projects difficult or wrong, if then only compared on price of construction or purchase. We have seen many wrong cases.

In Greenland, geography and settlement only allows for energy supply in what is referred to as "island-supply" - there is no connecting transmission grid between communities. Efficient energy management can thus only come about if the common interests of the local society are implemented in a financial analysis. If the municipal authorities, the individual house owner and Nukissiorfiit supra-optimizes but each to themselves, the result would not necessarily come out as intended, overall.

\section{Security strategies}

Security strategies is objectives, framework and procedures securing the consumers need for heat, electricity and water.

The security strategy is to determine that there is the necessary and adequate supply, the necessary and adequate emergency plans to take on break-downs, shipwreck or other discontinuations of the steady supply, given that the need calls for a steady and continuous supply.

Continuous supply is most commonly the objective for energy. Since storage of certain energy forms either is rather difficult and expensive or there have not yet been developed methods for storing the desired energy, large demands can be put on the technology and security applied. 
As noted in the introduction, not many of our life conditions can suffer freezing temperatures. We were reminded of this fact last time during the total break-down of power supply in Sisimiut.

Luckily our towns and for some part many of our settlements have yet to experience such a break-down as in Sisimiut, which served as a reminder that the level of security must be consciously decided upon.

Security should be subject for evaluation constantly. There is no doubt costs can be cut here, if security were to be less important. However, one should have a balanced approach here in looking at what parts of electricity-, water- and heating consumption that can tolerate a fallout, and for how long. A well-insulated house can endure longer fall-outs of heat than a similar house with lower insulation. The oil distributor and heat producer's security strategies thus depend on the state of the building mass.

\section{Legislation}

Laws and rules is one of the most effective energy management tools. I shall refer to this only shortly. By rules it is laid down which party is responsible for supply, e.g. is it a public or individual responsibility? Rules can point to specific energy sources to be used. Rules are about security, preparedness and authority. Regulation of financial subjects, prices, subsidies and taxes naturally belongs to the management tools.

The existing legislation is not necessarily clear and easy to apply, even though one could wish so. Perhaps there is a need for rules on some areas.

However, one should not always await the emergence of new rules. Many results can be achieved by insight and will to cooperate. The public supplier and the individual houseowner can in many situations together find the optimal solution for both partners.

\section{Tariffs and consumer behaviour}

The most essential management tool in Greenland has been the tariffs. They have been subjects of political decisions for many years. The large structural reforms for tariffs on electricity, water and heating took place in the 70s, 1980, 1992 and January 1, 2005.

Oil tariffs have been differentiated with a view to the fishing industry but has other than that not been a subject to structural reforms.

Managing consumption and the consumers' behaviour by means of tariffs comes with some difficulties that can lead to energy waste and paradoxical consumption. Furthermore there are virtually no scientific surveys on consumer response to higher or lower costs for these services. In Greenland the price elasticity is assumed to be quite small, since there are few energy alternatives.

Exactly because there are so few alternatives focus must be on effective heat supply, least heat loss and furthermore heat-regain. Heat constitutes our largest share of used energy and the largest savings could be found in this sector without a slack to the comfort.

\section{Other consumer-friendly energy management tools}

Finally, allow me to bring forward yet some tools making it possible for consumers to secure as much energy management as possible. 
Energy labels is a means of providing the necessary information on specific products' energy efficiency to the consumer.

It is, however, not sufficient only to mark product with energy labels. Information on and the possibility of acquiring products with high energy efficiency must literally speaking end up with the consumer by itself. May this be a suggestion to our own firms and stores on having focus on this issue.

The building mass and energy management is a huge subject. This relates to, e.g. planning with regards to energy efficiency in terms of heat, insulation, water supply, air conditioners, ventilation, lighting and much more. Furthermore, a regularly check of a buildings present state of energy efficiency with regards to an assessment on whether a replacement or renovation of some installation is necessary.

Finally, any management is to encompass a large share of energy management. This concerns all work places whether at home or in professional life. There is money to be gained by economising on consumption and thereby create sound consumer habits.

\section{CLOSING REMARKS}

Here at the very end it must be emphasised that those management tools mentioned herein in connection to energy efficiency and energy economising also relate to water supply. Fresh water is in shortage in quite a few local communities. Therefore an awareness of behaviour and management on relation to consumption seems in order.

This contribution has only emphatically touched upon who the decision-makers or initiators are. However, many parties control energy.

Still, I sense the need for further attention on this subject. This also because we all, either as individuals or as a society, are strongly dependent on the mass of energy available and of being able to afford it.

It is my belief that the low energy house in Sisimiut is an important piece when it comes to putting focus on these issues. I believe and hope that the scientific surveillance of the house will provide the publication of the vital results of the investment and running of it.

Thank you. 


\title{
Low Energy Housing Developments in Alaska
}

\author{
Richard D. Seifert, Professor, \\ Energy and Housing, University of Alaska Fairbanks, Fairbanks AK USA, ffrds@uaf.edu
}

\begin{abstract}
As northernmost state of the United States, Alaska covers a huge range of climatic zones. The consequent demands on housing technology are daunting. This paper attempts to give a historical review of the contributions and experience with low-energy, durable, climatically adapted housing technologies which have worked for us in Alaska. The effort to optimize housing for the extreme demands of northern life has led to a wide experience base. We have learned much over the past forty years both from our successes and our failures. In this paper I hope to cover some of the aspects of housing technology that we feel have matured, and in which we have confidence of their appropriateness for application to northern housing. Also described are other needs for which we still require better technological or material solutions.
\end{abstract}

\section{FIRST, SOME BACKGROUND:}

The housing culture in Alaska is a subset of the housing culture in the United States. In most aspects, this influence is highly negative. It has made Alaska a burgeoning, aspiring suburbia of single-family homes, with the consequent esthetic, and automobile dependence of more temperate climes. Much of the Alaska Native population is supported by Federal government housing programs, and is a low-bid culture, which tends to be driven by housing designs not appropriate climatically or structurally for Alaskan conditions. Added to this, is the "frontier" mentality, which has kept many of the suburban and rural areas of Alaska from having any building code protection or inspection (the Federal programs are exceptions to this). During the late 1970's and early 80's, even though mortgage interest rates were high, Alaska experienced a huge boom resulting from the money flowing from the Trans-Alaska Pipeline construction. Although many substandard, (at least from an insulation and comfort perspective) homes were built, this period was also the time of an emergent awareness of the need to improve the quality and energy efficiency of housing.

In 1987, the author, along with fellow Alaskan Cooperative Extension housing specialist Donald Markle, and a group of building science enthusiasts and homebuilders, created the Alaska Craftsman Home Program. This was an integrated effort to educate both the contractor/builders and the public occupants/purchasers of housing about the need for energy efficient, durable, and healthful housing design. The program was supported by state government largesse, and produced a very effective educational program, and was nearly single-handedly responsible for raising the general quality and insulation levels of Alaskan housing. Many of the ideas and program structure for this effort were also borrowed from the very helpful and always generous Canadians. Their R-2000 program and National Research Council work has always been the most important research base for us in Alaska. This is very good for us, and reflects the fact that we are not generally covered for our housing needs by typical US research, because we are a small population in Alaska, and have climates typical to our latitude. Canadians share all this with us, and the "lower-48" none of it. So Canada is our research support base, and we are our own natural laboratory for houses.

During the 1990's The Alaska Craftsman Program published it's most recent building construction manual entitled, "Northern Comfort", still a fine and relevant piece of work. More recently, another group, the Alaska Building Science Network (www.absn.com) with support from the Alaska Housing Finance Corporation and the University of Alaska Cooperative Extension service, has continued the educational work for both the public and the 
shelter industry, and publishes a quarterly newsletter, the Alaska Building Science News. This newsletter is shared with the Cooperative Extension Service of the University of Alaska and the author is its technical editor. These newsletters are archived at the website:

www.uaf.edu/coop-ext/faculty/seifert/energy.html

A new and nascent research center for housing has also come onto the scene in Alaska, the Cold Climate Housing Research Center. The intent for this center is to be the focus of continuing housing research specific to Alaska. Plans are to build a research building for this center on the campus of the University of Alaska in Fairbanks.

For more than 15 years, the Alaska Housing Finance Corporation has provided incentive loan programs for energy efficient housing, and the infrastructure for energy audits and tests of housing, with such technologies as blower doors, has been widely available in Alaska. Progress has been slow but very steady. Recently, very low interest rates for mortgages have quashed interest in energy efficient mortgage loans, but that may soon change when those mortgage rates rise. Presently the Alaskan housing education program consists of annual educational efforts by the author, which reach about 500 people with an intensive 7hour workshop on Cold Climate, or Marine Climate Homebuilding Techniques. The Alaska Building Science Network parallels the public education program with a contractor professional education program, the completion of which is required to get a residential contractor license endorsement.

\section{A FOCUS ON BUILDING SCIENCE AND STRUCTURAL REINFORCEMENT:} The primary focus of all our educational work in striving to improve the housing stock of Alaska, is understanding how buildings work, move, and fail in our environment. Basic building science is discussed in the course and we attempt to make it as understandable and within reach of most people as possible. It is also delivered to many primary Alaska Native audiences, and has been quite well received. Below, in figure 1, is a graphic depiction of the "Balancing of Building Physics" shown as a hanging mobile sculpture, very delicately balanced. This very clever depiction of the difficulty of balancing aspects of buildings to achieve a quality indoor environment is exemplary of our educational effort. In addition to the focus on building science, the education attempts to give prospective homeowners the information and technical advice they need to make the best decisions possible for their situation. Alaska, like Greenland, has some of the most difficult environments and climates in the world to cope with. Material choices are of paramount importance. Wind and seismic forces are variable and dramatic, depending on location. Structural reinforcement using hurricane ties, and seismic anchoring of building foundations is a major thrust of our education. Alaska is not only windy along its western and arctic coasts, but is also one of the most seismically active places on the "Pacific Rim of Fire", the infamous volcanic and earthquake-prone region around the Pacific Ocean. Figure 2 is a Landsat image of the November 3, 2002 earthquake which occurred along the Denali Fault in the eastern Alaska Range in Interior Alaska, and which strongly affected the Trans-Alaska Pipeline. This earthquake was the strongest in the entire world for 2002.

Fortunately, much of the structural reinforcement can be provided by products readymade for such use. Particularly easy to adapt and very effective are the Simpson Strong-tie products. These are metal, typically galvanized sheet steel, fastened with special (teco) nails or screws used to secure the joints to the structure. Metal connectors are vastly superior to any nail or screw fastening by itself, and the rigidity of such a structural reinforced building can enable it to withstand the hurricane winds legend at many coastal locations in Alaska. See figure 3 for an example of such joints and connectors. 


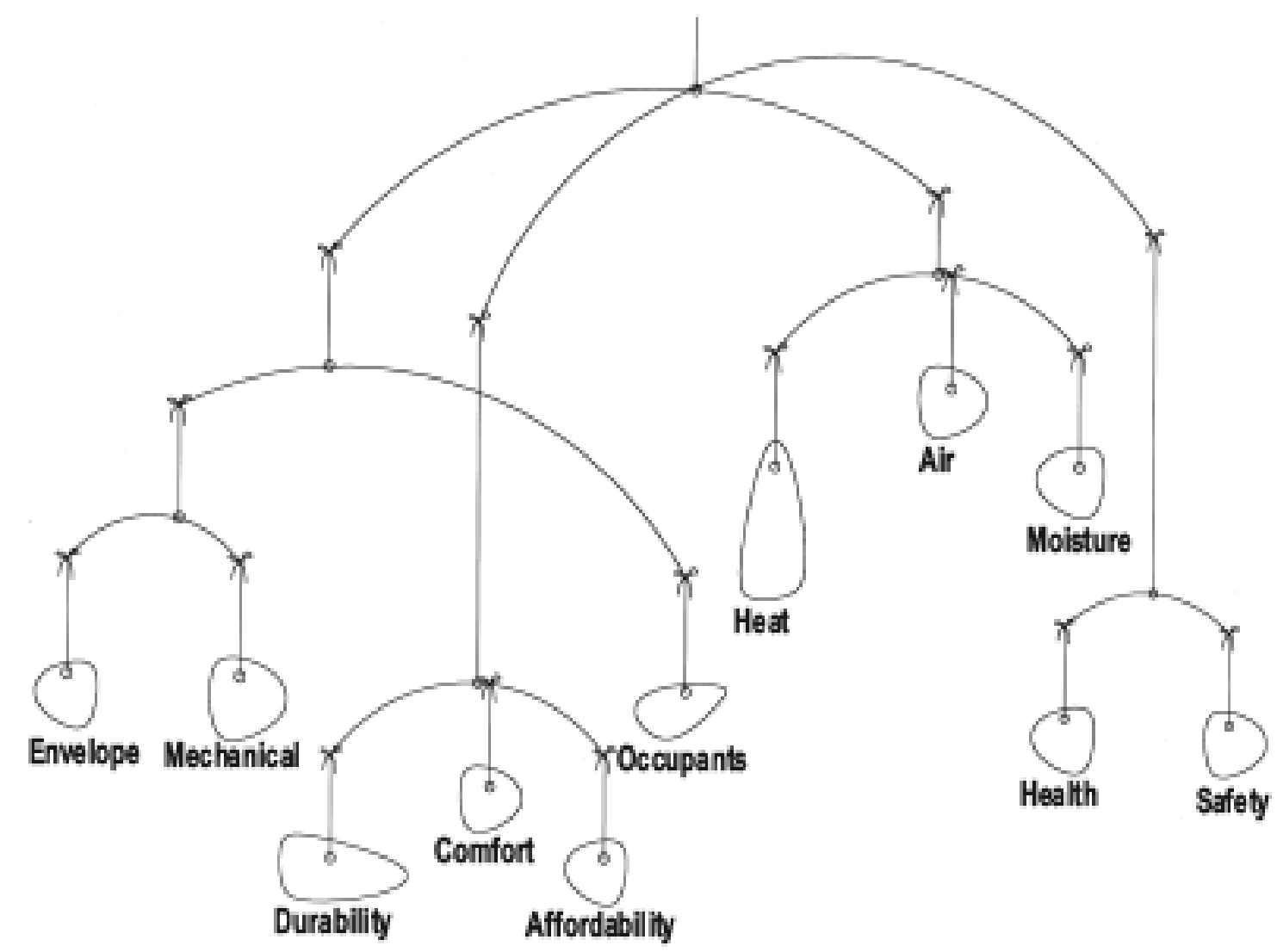

Figure 1: The "artful” Building Science balancing act. (From "The Alaska Housing Manual" Alaska Housing Finance Corporation, 2000)

Another aspect of climatic design that must be confronted in Southeastern Alaska particularly, is rain-screen exterior sheathing. This approach to protecting sheathing from rot and rain damage originated in Norway. The author spent a year in Norway in 1985-86, and brought this rain-screen wall design back to Alaska. In Norwegian it is called "Luftede Kledninger", and the original design was developed to respond to eliminating the wetting of exterior cladding in concert with insulation use after WW2. Clearly this system is most useful for wood exterior sheathing protection, and has been made moot in the case of PVC (polyvinyl chloride plastic) siding, which is inherently a rain-shedding cladding. However, in Alaska, we continue to predominantly use wood sheathings, and for that reason the publication serves our situation well. The availability of Dupont Tyvek also gives us a nearly perfect material for the backing of the ventilation cavity in such a wall. A photo of an exterior ventilated wall system under construction is shown in figure 4. It is likely that this type of wall system is highly appropriate to most conditions of coastal Greenland, but also depends on materials choices for the exterior cladding. 


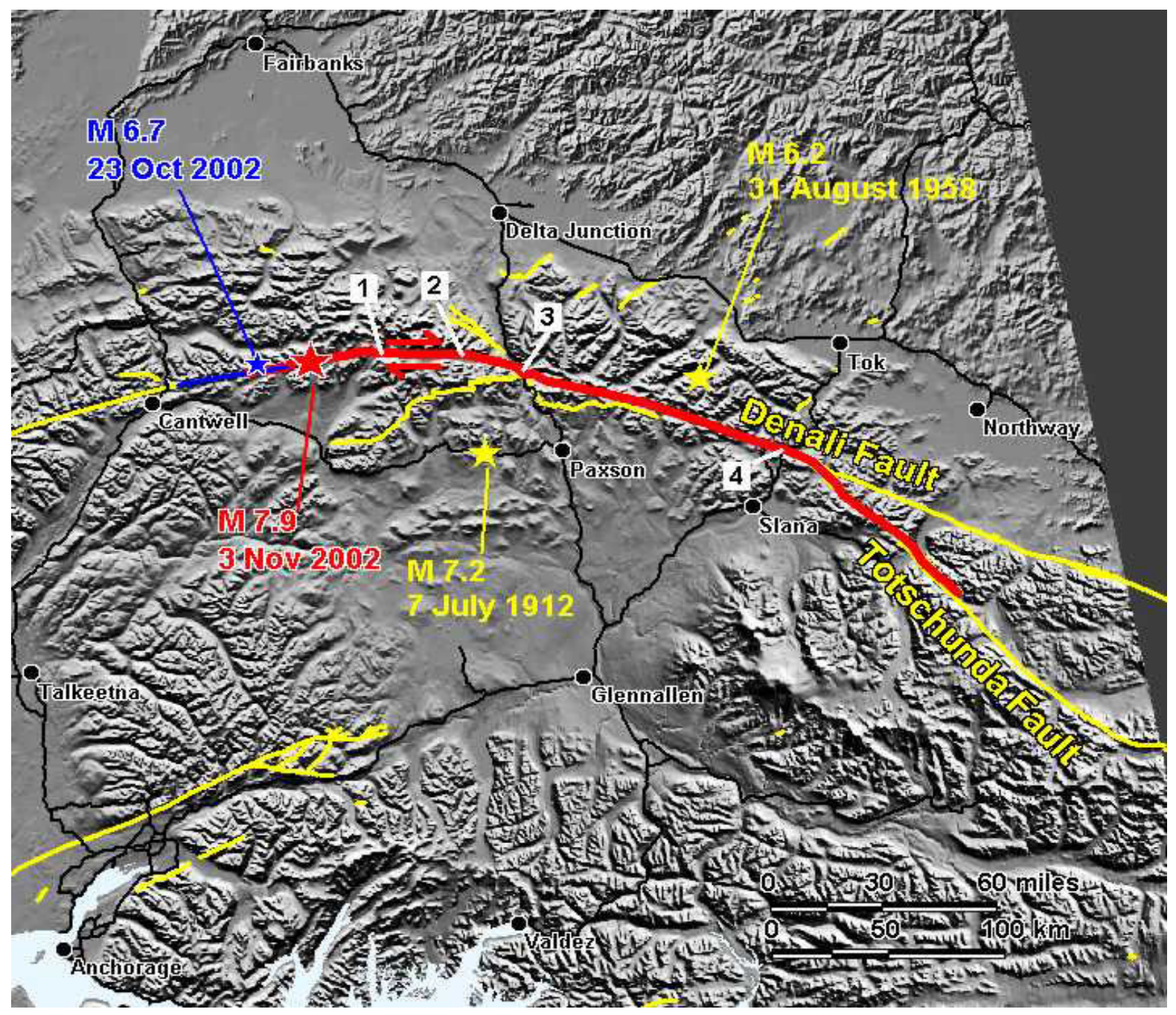

Figure 2: A Satellite map of the November 3, 2002 Earthquake in Interior Alaska. It is reputed that this earthquake actually moved the entire Chena River basin (the area around Fairbanks) 6 centimeters to the south. Damage was mostly confined to roads breaks, and the Trans-Alaska Oil Pipeline did not fail. 


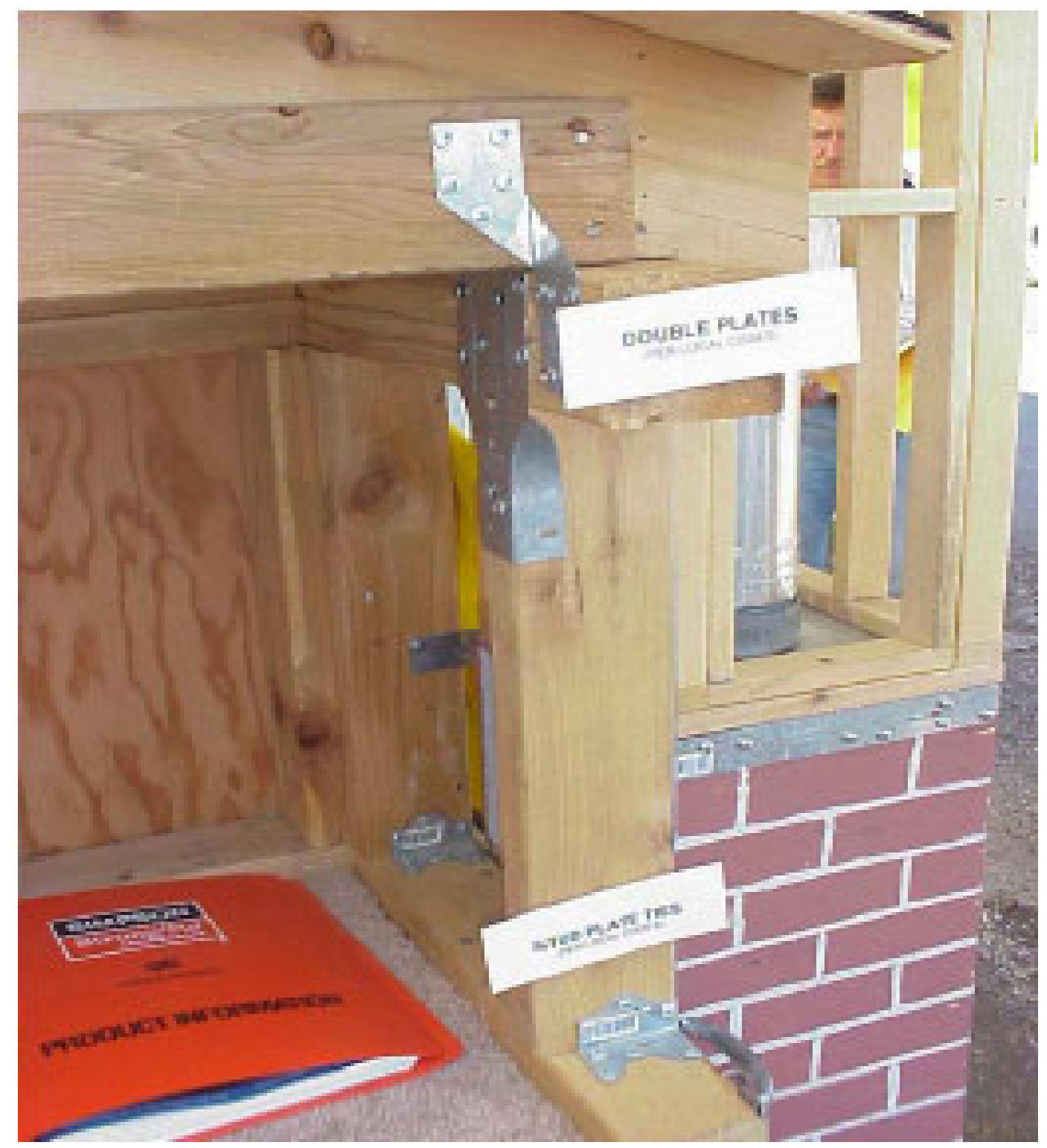

Figure 3: A model of various wall and roof joints showing seismic and wind anchors, which are commercially available and exceedingly worthy features in wind-prone and seismically active areas. The Alaska State Division of Emergency Services, motivated by the November 2002 earthquake, constructed this display. It is shown around the state as a public education display. (Photo by author). 


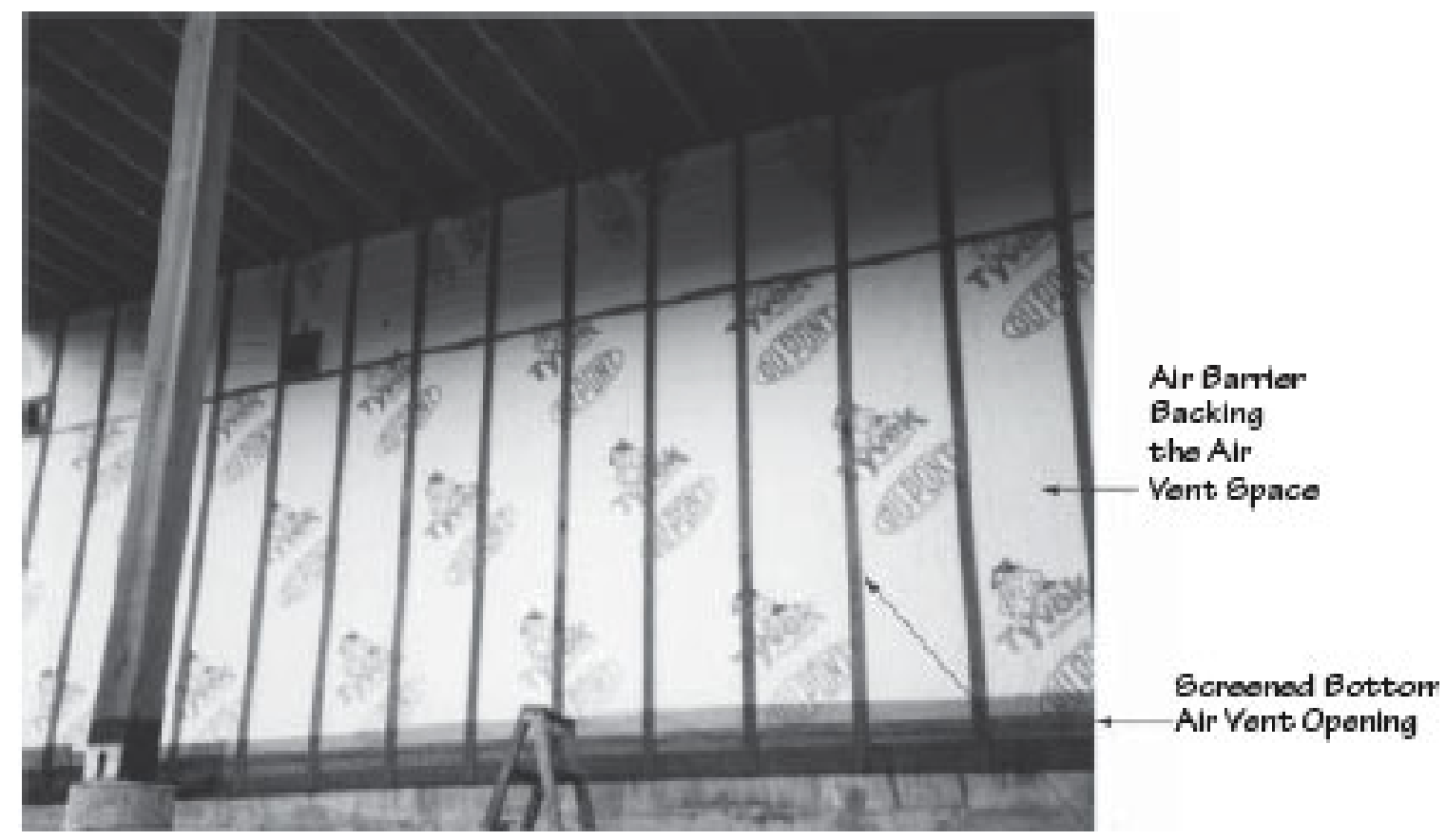

Figure 4: A photo of a ventilated exterior cladding system under construction in Southeast Alaska. (From an English translation of the NBI publication "Byggdetaljer: NBI Byggforsk A542.003", also published as Alaska Building Research Series HCM-01558, with additions and used with permission, 1988)

\section{In Summary}

Since I an somewhat limited for space in this paper, I will add some crucial short descriptions of building science techniques, details, and emerging current events which have contributed to our Alaskan experience in achieving durable, healthful, and energy efficient buildings for some of the most challenging climates in the world.

1. Build it tight and ventilate right. A basic major tenet of building science, control of air leakage (exfiltration and infiltration) is absolutely crucial to good indoor air quality, and healthful indoor climate. Without getting control of air leakage, none of the other important comfort and health aspects of the structure can be controlled, especially the heat loss and moisture loss which accompanies the air leakage. Ventilation control, particularly for heat recovery ventilation, might ideally be accomplished by humidistat control. However, this technology is not yet mature to the degree it is adequate for this use.

2. Seal the lid. WE have learned very clearly from the experience of weatherization teams throughout Alaska, that one of the most important details to ensure for best results, is to seal the air-vapor retarder at the ceiling (or wherever the top of the insulated house occurs). Whether or not the roof system is a cold roof or a hot roof design, both require that the warm side air-vapor retarder be very tightly sealed and durable. All other air leakage issues become easier to cope with if this single detail is done well. Since this stops much of the air leakage at the top of the house, air will not leak in low in the house to replace that lost air. The indoor relative humidity will also be higher and consequently healthier, since that loss of humid air is also reduced, 
achieving an indoor environment closer to that " tropical savannah we all wish to live in our homes.

3. "Tune" the foundation to the site conditions. The site conditions and soil types vary enormously in Alaska, and we have permafrost to deal with. More than $80 \%$ of building failures are due to foundation failures. Many new systems, such as the triodetic space frame, are appropriate for poor soils conditions and can be transported easily. I very windy situations, the foundation should be tied to the building and anchored to the surrounding soil or rock, depending on the site geology and exposure.

4. Ventilated, tight housing is healthy, comfortable and durable housing: The connection and importance of the relationship between human health and the indoor environment in our homes has led us to strive for the "Healthy House " as a premier goal for the building science community and public policy. Occupant health is a pervasive although difficult to correlate aspect of quality energy-efficient housing. Lately, research into the basic and crucial connection between health and housing quality has been made more difficult because it is so treacherous to do research when there are human subjects involved. Still, research is proceeding to document the effect of ventilating village housing in Alaska to prevent early childhood incidence of respiratory diseases which are higher in Alaska Natives than any other ethnic group. Another project is examining whether an improvement in energy efficiency in rural Alaskan homes (by weatherizing them) can result in reducing the incidence of asthma.

\section{References}

Bowers, Harvey, et alia. 1995. Northern Comfort, The manual of the Alaska Craftsman Home Program, Advanced Cold Climate Home Building Techniques. 220 pages plus appendices. Published by the Alaska Craftsman Home, Anchorage, Alaska.

Musick, Michael, et alia, 2000. "The Alaska Housing Manual" $4^{\text {th }}$ edition. Published by the Research and Rural Development Division of the Alaska Housing Finance Corporation, 4400 Boniface Parkway, Anchorage Alaska. 92 pp. Plus appendices and bibliography.

"Exterior Ventilated Cladding”. 1988, published in English by the author, from the original publication: Luftede Kledninger, NBI: A542.003 Byggforsk serien, by the Norwegian Building Research Institute, Oslo, Norway. 10pages.

Websites of interest:

www.absn.com Website of the Alaska Building Science Network www.uaf.edu/coop-exte/faculty/seifert/energy.html Website of the author, which has all the relevant building publications, plus many renewable energy concepts for northern applications. 


\title{
Experiences from Low Energy Houses in Canada
}

\author{
Robert S. Dumont, Building Performance Business Unit, Saskatchewan Research Council, \\ 15 Innovation Boulevard, Saskatoon, Saskatchewan Canada, S7N 2X8, dumont@src.sk.ca
}

\begin{abstract}
This paper presents an overview of the experience with low energy houses in Canada. The focus is primarily on houses built since 1977. The houses generally include the following features: a well sealed and very well insulated building envelope, heat recovery on the ventilation air, use of direct passive solar gain for space heating, low energy use lighting, and low energy use appliances. In addition, some homes have incorporated active solar space and water heating systems, and photovoltaic systems for the generation of electricity. The general approach has been to first apply the energy conservation measures and then to apply the renewable energy features.
\end{abstract}

\section{INTRODUCTION}

This paper presents an overview of the experience to date with low energy houses in Canada. The first wave of very low energy houses was initiated in the latter part of the 1970s, in response to the major rise in the price of oil in 1973.

Prior to 1973, however, there had been advances in Canada on low energy housing technology. In the 1920s some original experiments were done on the use of insulation in exterior walls and attics of houses. At that time, wood shavings from planer mills were being used to limit heat flows.

Much further back in time was the development of the knowledge about proper window orientation to provide passive solar heating. The book "A Golden Thread" (Butti, 1980) has an excellent description of the many low technology approaches that the natural scientists and philosophers developed to improved the thermal comfort levels in housing. Probably the most outstanding early contribution was the emphasis placed on the orientation of the houses toward the equator to improve the solar heat gains. The great philosopher Socrates is quoted by Xenophon as follows:"In houses that look toward the south, the sun penetrates the portico in winter, while in summer the path of the sun is right over our heads and above the roof so that there is shade."

The great playwright Asechylus suggested that a south-facing orientation was a normal characteristic of Greek homes. It was a sign of a "modern" or "civilized" dwelling, he declared, as opposed to houses built by primitives and barbarians who,"though they had eyes to see, they saw to no avail; they had ears, but understood not....They lacked knowledge of houses...turned to face the sun, dwelling beneath the ground like swarming ants in sunless caves." (Butti, 1980)

In the 20th century, there have been many breakthroughs or inventions that have allowed us to improve the energy efficiency of houses, but it is still the orientation of the house towards the sun that is the key to achieving superior performance. Although this information is well known to the energy efficient design community, city street layouts in many parts of Canada continue to be built without regard for the orientation of the dwellings for passive solar use. 
SOLAR COLLECTOR BASED APPROACHES- A U.S. EXAMPLE

One of the first attempts at achieving a very energy efficient dwelling in a colder climate was built in 1939 (Hottel 1942) and monitored over the period up to 1941 at the Massachusetts Institute of Technology in Cambridge, Massachusetts.

The 46 square metre floor area test house achieved 100\% solar heating using triple glazed liquid solar collectors and a very large storage tank (the tank volume was equal in size to $71 \%$ of the livable volume of the house). The insulation levels for the house were quite moderate by today's standards, with the wall insulation being $92 \mathrm{~mm}$ of rock wool and the ceiling insulation being $100 \mathrm{~mm}$ of rock wool. Because of World War II, work on this project house ceased. The high cost of the storage tank and the solar collectors (the collector area was equal to $72 \%$ of the floor area) made the house financially unattractive to duplicate on a large scale, given the relatively low prices of fossil fuels at the time, and also the lack of knowledge at the time of the environmental consequences of burning fossil fuels. Nonetheless, the achievement of $100 \%$ solar heating in a relatively cool and overcast climate some 50 years ago was remarkable. Another major achievement of this project was the development of the theory of flat plate solar collectors. Several other solar houses were also built at MIT during the 1940's and 1950's.

During the 1940 's, 1950 's, and 1960 's, a small amount of innovation took place took place in the area of energy efficient buildings. Sealed pane windows, vapour barriers and forced warm air furnaces were some of the innovations that materialized. Very little progress occurred in the use of higher insulation levels in houses, however, and as late as 1975 houses were being built in as cold a climate as Saskatchewan with as little as $60 \mathrm{~mm}$ of wall insulation (even though the stud cavity was $89 \mathrm{~mm}$ wide).

\section{INNOVATIVE HOUSES OF THE 1970'S}

\section{The Zero Energy House in Denmark}

A super energy efficient house (Korsgaard,1977) was built in 1975 near Copenhagen in Denmark. Called the "Zero Energy House," this house was unique in that it was probably the first super-insulated house in the world. The house had approximately $300 \mathrm{~mm}$ of mineral wool insulation in the walls and floor. This amount of insulation was approximately 3 times as large as that used on most houses at the time. It incorporated insulating shutters on the windows, one of the first air to air heat exchangers ever used on a domestic residence, and a solar heating system that was designed for $100 \%$ solar space and water heating. Despite some problems with air sealing of the envelope, and breakage of glass on the solar collectors, the house was able to achieve close to $100 \%$ space heating from the solar system. However, because of the large amount of water storage used (equal to $35 \%$ of the volume of the house), the solar heating system on the house did not become commercially attractive.

\section{The Lo-Cal House}

In 1976, an architect, Wayne Schick, at the Small Homes Council at the University of Illinois at Urbana-Champaign developed a design known as the "Lo-Cal" house (Schick, 1979). It included double 38 x 89 walls with RSI 5.3 walls, ceilings with RSI 7.0 insulation, and double glazed windows with most of the windows on the south side. Although the house was not built, many of the ideas were to be adopted in other low energy houses. 


\section{The Saskatchewan Conservation House}

Located in Regina, Saskatchewan, the Saskatchewan Conservation House (Besant et al, 1977) house was completed in 1977. The house incorporated a number of innovative energy conserving features:

1. High performance evacuated tube solar collectors.

2. A grey water heat exchanger.

3. An air to air heat exchanger using plastic heat transfer surfaces.

4. Exterior, motor driven insulating shutters.

5. A well sealed air-vapour barrier. Based on pressure test results, this was the tightest house envelope that had ever been constructed in Canada as of 1977. (The pressure test result was 1.3 air changes per hour at a pressure difference of 50 Pascals. Conventional homes of the same age typically are about 3 times as leaky.) Under natural conditions, the average air change rate of the Conservation House is less than 0.1 air changes per hour.

6. Use of modest south-facing windows for passive solar gain in a light frame building with no additional thermal mass. The south-facing window area on the building was only about $6 \%$ of the total floor area; there were no windows on the east and west facades, and only 1.9 square metres on the north side.

7. Use of very high insulation levels for Canadian houses of that vintage. Cellulose insulation was used in the floor (RSI 7) and ceiling (RSI 10.7) and glass fibre batts (RSI 7.7) were used in the walls.

The house was designed for 100\% solar space heating (Besant et al, 1979), but compared to previous houses of that type it was able to get by with a radically reduced amount of solar collectors and volume of heat storage. The Saskatchewan Conservation House was designed to provide $100 \%$ solar heating in a very cold climate using a solar collector that was only $10 \%$ of the floor area and a water storage volume equal to only $2.8 \%$ of the house volume.

Because of the relatively high cost for the solar collectors, and the teething problems with pumps, sensors, and controllers, the use of solar collectors for space heating did not seem attractive. Typically, the solar collector systems were costing approximately $\$ 500$ per square metre of collector, which at the time was roughly the same cost per square metre as building an entire house.

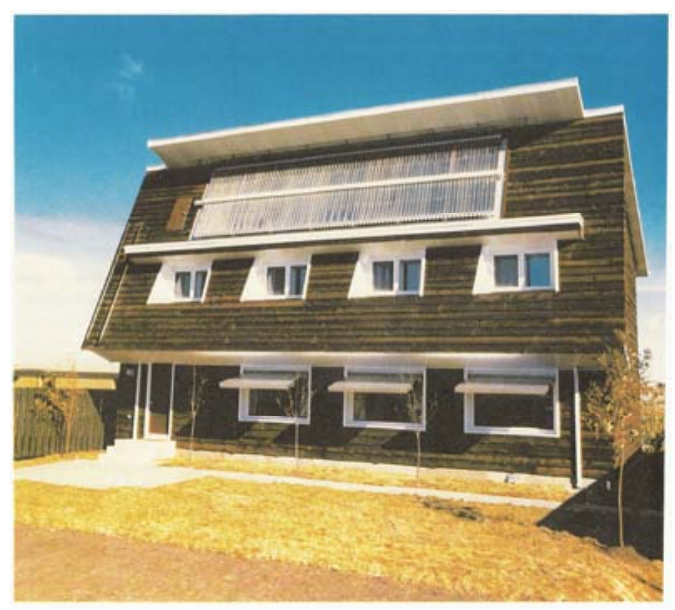

Figure 1. South Side of the Saskatchewan Conservation House, 1977. Note the active solar panels (vacuum tube) on the upper part of the south wall, and the insulating shutters on the lower windows. An 11,000 litre water storage tank was incorporated to store solar heat within the house. 
Because of the problem of high costs, and relatively low natural gas prices at the time, the idea of using solar panels for space heating did not become very popular in Canada. However, many of the other conservation features used on the Saskatchewan Conservation House did prove to be more attractive.

\section{Light and Tight versus Mass and Glass}

During the 1970's there developed two schools of thought regarding the best means of achieving low space heating consumption using simple, passive means. One school (Balcomb et al, 1980) emphasized the use of large south windows with large amounts of thermal mass. This school became known as the "Mass and Glass" proponents. The other group, which favoured the use of modest south facing windows and instead emphasized large amounts of insulation and a well sealed envelope, became known as the "Light and Tight" group.

One of the major problems with the "Mass and Glass" approach was that the net solar gain (incoming solar radiation minus heat losses) for south facing windows in a cold climate such as Saskatchewan can be quite small. For instance, a standard double glazed window facing South in a Saskatoon home will actually have a net heat loss over the months from November to February. Adding more south glazing actually makes the heating performance of the house worse. A 1979 paper (Dumont et al, 1979) documents this for an energy conserving house with $32.5 \mathrm{~m}^{2}$ of south glass. The house performs considerably worse than does a house with only $11.7 \mathrm{~m}^{2}$ of south glass.

In the latter part of the 1980's, much better windows (sometimes called superwindows) reached the market. Windows incorporating low emissivity coatings and low conductivity gases such as argon became available.

With high performance windows, south facing glazing has a much higher potential for space heating, and it is possible that the "Mass and Glass" approach may become more popular in the future. One major obstacle that remains is that mass incorporated in wood frame construction houses tends to be quite expensive. Other means of storing heat in a passive manner, such as the use of latent heat storage with salt-hydrate compounds, are expensive also.

\section{The Energy Showcase Project}

In 1980, following on the success of the Saskatchewan Conservation House, a project of 14 houses called the Energy Showcase Project (SEM, 1982) was built in Saskatoon that incorporated a number of the features pioneered in the Conservation House.

A major innovative feature of the program was the use of a performance target for space heating for the houses, instead of prescriptive targets. For these 14 houses, the annual space heating target was set at 200 Megajoules $/ \mathrm{m}^{2}\left(55.5 \mathrm{kWh} / \mathrm{m}^{2}\right)$, or approximately one-third that of conventional houses.

Because of the absence of computer programs at that time to calculate the annual heating performance of houses, a short series of programs called HSLOAD and HSSUN were written, which later became the commercially sold program HOTCAN (Dumont et al, 1982), which in turn became the program HOT 2000 (CHBA, 1990). These programs allowed the builder or designer to estimate the yearly space heating consumption of the houses before construction. 
In the Energy Showcase, a number of innovations were tried by the builders. These innovations included the following:

1. Use of a single hot water heater to provide both space and water heating to a residence. (As many of the residential water heaters have output ratings of about $8.3 \mathrm{~kW}$, such units would have sufficient output to provide both space and water heating to the low energy residences, which often had design heat loss values less than about $7 \mathrm{~kW}$.

2. Unfortunately, in 1980, there were almost no high efficiency residential water heaters.)

3. Use of quadruple pane windows.

4. As no such units were commercially available, one designer assembled two double pane units.

5. Use of even higher insulation levels than used on the Saskatchewan Conservation House. One house featured walls with RSI 10.5 (R 60) insulation.

6. Use of various window insulating schemes. Beadwall and roll-up insulating multilayer curtains were both tried.

The energy performance target for the project was well-received, and was incorporated in the Canadian R-2000 program.

\section{The R-2000 Program}

A major initiative in low energy housing was announced in 1980 by the Canadian Federal Government Department of Energy, Mines and Resources. The program became known as the R-2000 program.

The program was run through the Canadian Home Builders' Association. The program had a strong emphasis on performance, as opposed to prescriptive standards for energy use for space heating. In the Saskatoon and Regina climate zones, the annual space heating performance target is about $60 \mathrm{kWh} / \mathrm{m}^{2}$. The first group of monitored R-2000 houses consumed about $57 \%$ less energy than conventional houses.

\section{The Brampton Advanced House}

In 1990, a second generation low energy house (White, 1990) was constructed in Brampton, Ontario (near Toronto). This house incorporates some of the state of the art energy efficiency measures and has a total energy consumption which is about $40 \mathrm{kWh} / \mathrm{m}^{2}$ per year. A major innovation with this house was the use of very efficient lights and appliances so as to reduce the base electricity consumption of the house. In addition, an innovative heat pump integrated mechanical system is used to provide space heating, water heating, ventilation, and space cooling.

\section{The Advanced Houses Project}

In 1991, a new program called the Advanced Homes Field Trials was initiated by the Federal Department of Energy, Mines and Resources and the Canadian Home builders' Association. In addition to space heating reduction, the program also targeted reduced energy use for domestic water heating, lighting, and appliances. The tentative target was to reduce the total energy consumption of the houses by 50\% compared to the already reduced R-2000 target. The program also included reducing water consumption, using recycled products, addressing indoor air quality guidelines, and providing facilities for recycling of materials. Ten advanced houses were built during 1992 and 1993 in Canada. 
The ten houses used a variety of approaches (Mayo et al, 1992) to improve energy efficiency, but all the homes included the following:

a. High levels of building envelope thermal insulation.

b. Improved windows with low emissivity coatings, argon gas fill, triple glazing, low conductivity spacer bars and low conductivity (mostly wood) frame materials.

c. Use of passive solar gain (direct gain with little or no added thermal mass) on all but one of the 10 houses.

d. Improved air tightness. The program goal was an air leakage rate not to exceed 1.5 air changes per hour at 50 pascals. All of the homes met the target.

e. Air to air heat exchangers

For space heating, half of the homes used a condensing natural gas water heater to provide both space and water heating. One of the consistent findings from the monitoring of the houses was that the seasonal efficiency of the condensing water heater was well below the manufacturer's steady state value of approximately 94\%. The actual efficiency of the water heaters was more in the range of about $60 \%$ when used in a space heating application. There are several reasons for the low seasonal efficiency of the water heater:

a. The return water temperature from the space heating system to the water heater was generally higher than about $55 \mathrm{C}$, with the result that the water heater did not condense. (The return water should be below about the dew point of the exhaust gases, or about $55 \mathrm{C}$ for condensation of the exhaust gases to occur.)

b. The thermostatic control for the water heater had a very narrow temperature deadband, with the result that the water heater cycled on and off at a very high rate when the units were used to provide space heating. Each time the water heater started, a purge cycle was initiated which brought in outside air, reducing the energy efficiency.

c. The firing rate of the water heater was quite large at about $29 \mathrm{~kW}$; the peak heat requirement of the houses was only about $10 \mathrm{~kW}$. Thus the water heaters would cycle on and off quite frequently.

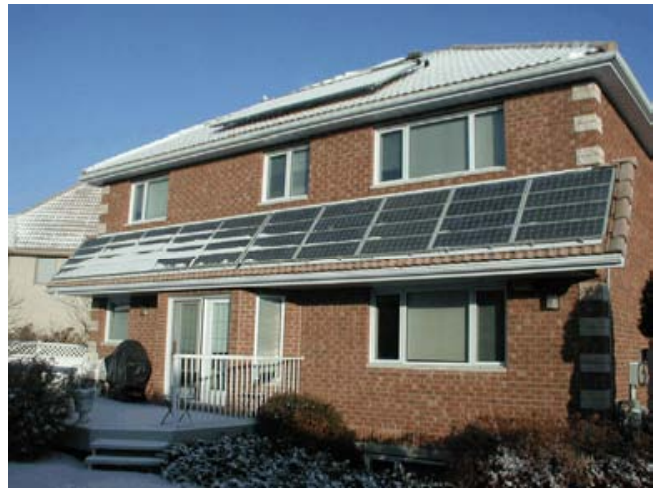

Figure 2. South side of the Saskatchewan Advanced House. One of 10 Advanced Houses built in Canada as part of a national project. Note the vacuum tube solar panels on the roof and the photovoltaic panels on the south wall. In very cold weather the snow will not readily melt off sloped surfaces.

\section{Dumont Residence}

The author of this paper built a new home in Saskatoon in 1992. The house has been described as "The Best Insulated House on Earth." (Dumont, 2000). The single family residence incorporates very high insulation values: RSI 14 in the Attic; RSI 10.6 in the walls 
and basement walls, and RSI 6.2 in the basement floor. The windows are triple glazed with argon gas, two low e coatings, low conductivity spacer bars. Appliances were chosen for low energy consumption; mostly compact fluorescent lamps were used; water conservation devices including low flow showerheads, low water use toilets, low water use landscaping and a variable water level washing machine were all used.

For renewable energy, the house incorporates passive solar heating through south facing windows, and also has an active solar space heating system with 15.6 square metres of single glazed, low emissivity coated, south facing solar panels tilted at an angle of 70 degrees to the horizontal. A site-built storage tank located in the basement has an EPDM sheet membrane liner with a volume of 2950 litres.

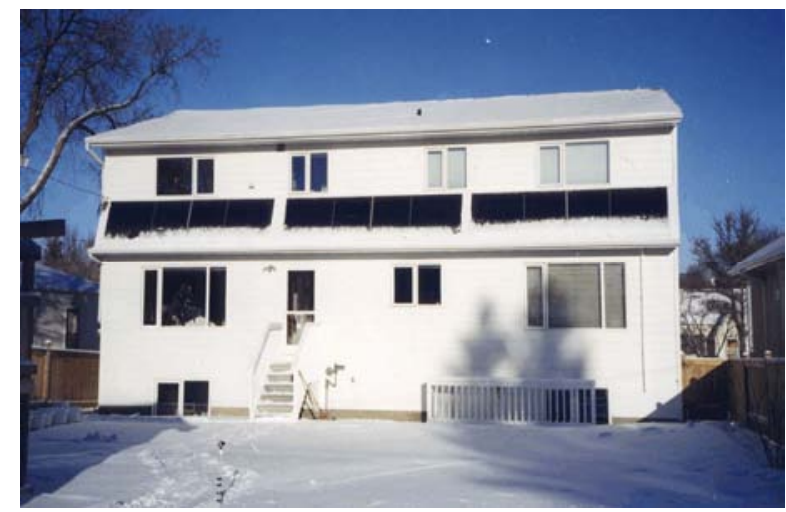

Figure 3. South side of the Dumont Residence, Saskatoon, December photo

Measured Energy Consumption of Various Canadian Demonstration Houses

The following table summarizes the annual purchased energy consumption of various Canadian Demonstration Houses in a colder province.

Table 1. Measured Annual Energy Consumption of Canadian Cold Climate Demonstration Houses.

\begin{tabular}{|c|c|c|c|c|}
\hline & $\begin{array}{c}\text { Annual } \\
\text { Purchased } \\
\text { Energy } \\
\text { (kWh/square } \\
\text { metre of floor } \\
\text { area including } \\
\text { basement) }\end{array}$ & Location & $\begin{array}{c}\text { Outdoor Design } \\
\text { Temper-ature } \\
\text { (January2.5\%) } \\
{ }^{\circ} \mathrm{C}\end{array}$ & $\begin{array}{c}\text { Annual } \\
\text { Average } \\
\text { Heating } \\
\text { Degree- } \\
\text { Days } \\
\text { (base } 18^{\circ} \mathrm{C} \text { ) }\end{array}$ \\
\hline $\begin{array}{l}\text { Saskatchewan } \\
\text { Conservation } \\
\text { House, } 1977\end{array}$ & 76 & $\begin{array}{c}\text { Regina, } \\
\text { Saskatchewan }\end{array}$ & -34 & 5750 \\
\hline $\begin{array}{l}\text { Energy Showcase } \\
\text { Project, Saskatoon, } \\
14 \text { Houses, } 1980\end{array}$ & 140 & $\begin{array}{l}\text { Saskatoon, } \\
\text { Saskatchewan }\end{array}$ & -35 & 5950 \\
\hline $\begin{array}{l}\text { Saskatchewan } \\
\text { Advanced House, } \\
1992\end{array}$ & 92 & $\begin{array}{l}\text { Saskatoon, } \\
\text { Saskatchewan }\end{array}$ & -35 & 5950 \\
\hline $\begin{array}{l}\text { Dumont Residence, } \\
1992\end{array}$ & 47 & $\begin{array}{l}\text { Saskatoon, } \\
\text { Saskatchewan }\end{array}$ & -35 & 5950 \\
\hline
\end{tabular}


The energy consumption of typical 1970 conventional houses in Regina is approximately 250 - $300 \mathrm{kWh} /$ sq.m per year

\section{Is a Zero Energy House possible in a Cold Climate?}

A reasonable question to ask is whether it would be possible to extend the energy conservation features and renewable energy features and build a house in a cold climate such as Saskatchewan that was completely autonomous in its energy supply.

Technically, it now is feasible. Here is an outline of how it might be done.

1. Water Heating.

The water heating load could be carried by a solar collector system coupled with water storage. An average house incorporating water saving features uses about $4000 \mathrm{kWh} / \mathrm{yr}$ for domestic water heating. A solar collector with $40 \%$ annual efficiency can collect about 550 $\mathrm{kWh} / \mathrm{m}^{2}$ of useful solar heat. Thus a collector of about 7 square metres, coupled with a large water storage, can provide the domestic water load.

\section{Space Heating.}

Space heating could be provided by using a highly energy efficient envelope for the building coupled with super-window technology. The solar collector system could be sized to provide the space heating that was not carried by the passive solar contribution. In effect, such a water and space heating system would resemble the 1977 Saskatchewan Conservation House approach. Advances in computer modelling, solar collection devices, storage and distribution technologies all appear to make such an approach feasible. On the Saskatchewan Conservation House, a total solar collector area of $17.8 \mathrm{~m}^{2}$ was used to provide both space and water heating.

\section{Supply of electricity for lights and appliances}

The supply of electricity is the most expensive element, given today's technology. In a windy location in a rural area, a wind electric system could be used. In an urban area, it would appear that the use of photovoltaic cells would be the most attractive. In recent years, the price of cells has declined. Some preliminary calculations indicate that by using the best state of the art energy efficient appliances and lights that the amount of electrical energy in a typical residence can be reduced to approximately $2000 \mathrm{kWh} / \mathrm{yr}$, for a reduction of about $75 \%$ compared to conventional houses. A solar electric system able to provide that amount of electricity would have to be about $16 \mathrm{~m}^{2}$ in area on an assured basis year-round in a location such as Saskatoon.

A legitimate question to ask is whether such an approach is economically attractive. However, a more fundamental question is "What is the real cost of energy?" In addition to the cost of extracting, processing, and delivering energy, there is the very substantial environmental cost, which today is not being paid. There is no charge to the consumer of energy for all the pollutants released into the atmosphere from the burning of fossil fuels. Carbon dioxide levels in the atmosphere are now 25\% higher than a century ago, and are rising each year.

Almost all the energy used in Saskatchewan is fossil fuel based, and Saskatchewan (Lobbe, 1990) has a per capita release of 8.6 tonnes of carbon per person per year, or approximately 8 times the average per capita value for the world. 
Were the real costs of energy to be paid, it is much more likely that autonomous houses would be feasible.

\section{CONCLUSION}

Much progress has occurred since the 1970's in our understanding of how to construct energy efficient houses. Houses that use $80 \%$ less energy than conventional 1970 vintage houses have been constructed.

With concern about the harmful environmental effects of fossil fuel burning increasing, it is possible that cold-climate houses that are completely autonomous in their energy supply using solar energy will be built in the near future.

\section{REFERENCES}

Balcomb, J.D., Barley, D., McFarland, R., Perry, J., Wray, W. and Noll, S., 1980, Passive Solar Design Handbook, Volume 2, U.S. Department of Energy, Washington, D.C. DOE/CS$0127 / 2$

Besant, R.W., Schoenau, G.J., Dumont, R.S., and Eyre, D., 1977, Design of a solar heated conservation house for Western Canada, Proceedings, Annual Conference, ISES American Section, Orlando, Florida

Besant, R.W., and Dumont, R.S. 1979, Comparison of 100 per cent solar heated residences using active solar collection systems, Solar Energy, Vol. 22 pp 451-453, Pergamon Press

Butti, K. and Perlin, J., 1980, A Golden Thread: 2500 years of Solar Architecture and Technology, Cheshire Books, Palo Alto, California

Canadian Home Builders' Association, HOT 2000 Computer Program, available from CHBA, Suite 702200 Elgin St., Ottawa, Ontario, K2P 1L5

Dumont, R.S., Besant, R.W., Jones, G., and Kyle, R., 1978, Passive Solar Heating--Results from Two Saskatchewan Residences, Proceedings, 1978 Annual Meeting, Solar Energy Society of Canada, London, Ontario

Dumont, R.S., Lux, M.E. and Orr, H.W., HOTCAN: A computer program for estimating the space heating of residences, DBR Computer Program No. 49, Division of Buuilding Research, National Research Council of Canada, 1982

Dumont, R.S., "The Best Insulated House in the World," Home Energy Magazine, Volume 17, Number 3, May/June 2000

Hottel, H.C. and Woertz, B.B., 1942, The performance of flat-plate solar heat collectors, Transactions, ASME 64, 91.

Korsgaard, V., 1977, Zero Energy Houses, Report NP-22388, N.T.I.S. Springfield, Virginia

Lobbe Technologies Ltd.,1990, "An Assessment of Technologies and Policy Options for Reduction of Greenhouse Gas Emissions in Saskatchewan," Regina 
Saskatchewan Department of Energy and Mines, 1982, Saskatoon Low Energy Market Housing Project, Final Technical Report, Miscellaneous Report FP-13, Regina

Mayo, T., Sinha, R., and Dumont, R.S., "Major Energy Conserving Features of the Canadian Advanced Houses Competion Winners," Solar Energy Society of Canada, Annual Meeting, Edmonton, Alberta, 1992

Schick, W. et al, 1979, Technical Note 14; Details and Engineering Analysis of the Illinois Lo-Cal House, Small Homes Council, Building Research Council, University of Illinois, Urbana, Illinois

White, E. and Carpenter, S., 1990, The Advanced House: Construction, Commissioning, and Preliminary Monitoring Results, Proceedings, 1990 Annual Meeting, Solar Energy Society of Canada, Halifax, Nova Scotia, Canada 


\title{
Advanced buildings in Iceland - different natural forces and resources
}

Jon Sigurjonsson, civ ing, The Icelandic Building Research Institute, Keldnaholt, 112 Reykjavik, Iceland, jon.s@rabygg.is.

\begin{abstract}
In this paper it is the main aim to present the nature forces that influence the building environment in Iceland and that way try to explain the reason for the Icelandic design mode that has been developing during the last century. These forces include windy weather, corrosion loads, earthquakes, snow avalanches and volcanic activity. The official requirements included in the building regulation are discussed. The natural resources, geothermal hot water and hydropower in the country, give the Icelanders the possibility of utilizing inexpensive energy both for heating and lighting. At last in this paper is a short overview of the modern building technique used in Iceland.
\end{abstract}

\section{INTRODUCTION}

Iceland is an island in the middle of the Atlantic Ocean, at latitude of $63-66{ }^{\circ} \mathrm{N}$, and is in the main path of low-pressure systems in this part of the world. The country is dominated by a mountainous central part (highest peak $2119 \mathrm{~m}$ ) and glaciers, with lowlands mainly along the south and west coasts. The climate is therefore characterized by a wet and windy southern and south western part and a colder and dryer northern part.

The corrosion environment ranges from a wet, chloride-rich area in the south, to a dry and colder area in the north. In fact, the biggest desert in Europe is in Iceland. In the windy environment, pollution is seldom a problem for people or materials. Wind load is sometimes very heavy and wind speeds over $52 \mathrm{~m} / \mathrm{s}$ are frequent in periods of 10 seconds in some parts of the country. Snow loads are high in the north and in the western part. Risk of avalanches is mostly in the west and in the eastern part because of the height and steepness of the mountains.

Average yearly temperature is between $3-5{ }^{\circ} \mathrm{C}$ warmer in the south around the capital Reykjavik than in the northern part. Earthquake zones are located from the south western part to the north eastern part of the island. However, the risk is rather low in the south eastern and the north western parts of the country. The island is highly volcanic and very difficult and almost impossible to say where or when the next eruption will occur.

\section{NATURAL FORCES}

\section{Snow load}

The Building Regulation in Iceland permits the use of two sets of structural design standards. On one hand the Danish design standards with Icelandic special requirements can be used and on the other hand the Eurocodes with Icelandic National Application Documents can be used.

The snow loads to be used in Iceland are defined in five zones according to Table 2.1. A map showing the zoning is provided in the standards. 
Table 2.1 Snow Loads on ground in Iceland

\begin{tabular}{lll}
\hline Zone & $\mathrm{S}_{\mathrm{k}}\left(\mathrm{kN} / \mathrm{m}^{2}\right)$ & $\mathrm{S}_{\mathrm{k}}{ }^{*}\left(\mathrm{kN} / \mathrm{m}^{2}\right)$ \\
\hline 1 & 2,1 & 2,1 \\
\hline 2 & $2,2-3,8$ & 3,0 \\
\hline 3 & $3,9-6,1$ & 5,0 \\
\hline 4 & $\geq 6,1$ & $\geq 6,1$ \\
\hline $\mathrm{H}$ & Special assessment & Special assessment \\
\hline
\end{tabular}

Local Building Officials are permitted to decide design values within the values given in the table. If no decision has been issued by the official design has to be carried out using values not lower given in the last column $\left(\mathrm{S}_{\mathrm{k}}{ }^{*}\right)$. In addition to zone $\mathrm{H}$ designers and officials have to make a special assessment in mountainous areas and in areas known for snow accumulation. In addition, it is of use to inform that the exposure coefficient $C_{e}$ has been fixed at 0,6 .

\section{Snow avalanche}

A regulation was issued by The Ministry of Environment on July 6, 2000 concerning risk assessment and definition of loads from avalanches. Zones A, B and C are defined in the regulation.

In Zone $A$ it is allowed to build new residential houses and industrial buildings. Apartment buildings, schools, hospitals and community centres have to be strengthened to withstand defined loads, see table 2.2 .

In Zone $B$ it is also allowed to build new residential houses and industrial buildings. Additions to apartment buildings, schools, hospitals and community centres can be built if they are strengthened to withstand defined loads, see table 2.2.

In Zone $C$ it is only allowed to build buildings if occupation is not permanent.

Structural engineers have to submit their design calculations in all cases. Guidelines in three technical papers have been published by The Icelandic Building Research Institute to guide the design work in avalanche risk zones. The joint title for the papers is "Design of houses in avalanche risk zones" and the subtitles are "Definition of load", "Structural design with examples" and "House types and technical guidelines".

Table 2.2 Avalanche Pressure within Risk Zones

\begin{tabular}{lll}
\hline Zone & Lower value & Upper value \\
\hline $\mathrm{A}$ & 5 & 20 \\
\hline $\mathrm{B}$ & 20 & 90 \\
\hline
\end{tabular}

Values within each zone shall be assessed based on location and local conditions. 


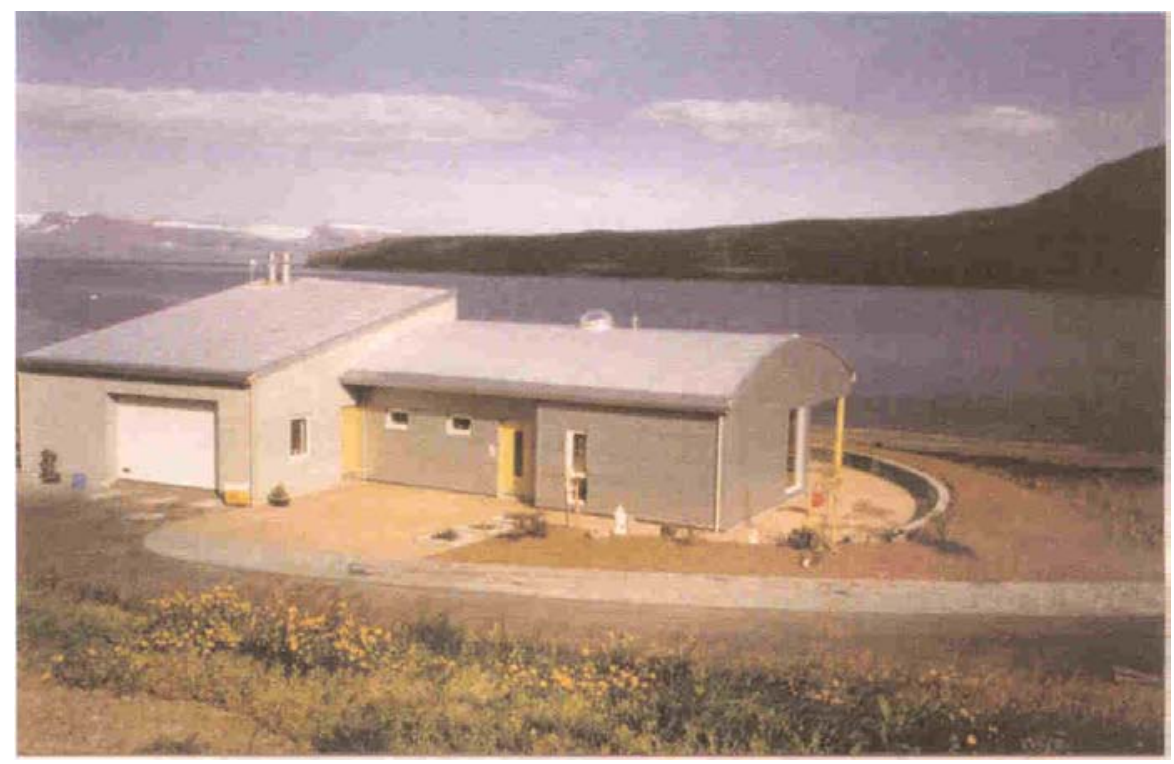

Figure 2.2 House on avalanche risk Zone, designed for exceptional load.

\section{Wind load}

The wind load to be used in Iceland has been defined with the basic value for wind speed as $35,5 \mathrm{~m} / \mathrm{sec}$ for terrain category II $\left(\mathrm{z}_{0}=0,05 \mathrm{~m}\right)$. When designing for Icelandic conditions it generally acceptable to use $z_{0}=0,03 \mathrm{~m}$. If other values are to be used the designer has to provide a detailed reasoning to be approved by the local Building Official.

The windy circumstances require the construction of airtight buildings to achieve energy efficiency and for the comfort the habitants.

\section{Corrosion load}

Corrosion of metals, especially steel, in Iceland varies widely with location. The main corrosive factor is seemingly the airborne salinity in addition to the humid environment. An ongoing project measures the atmospheric corrosion in Iceland, which makes comparison with other countries a possibility. The corrosion rate has been measured over five years and the project will continue for a total of ten years.

Functions predicting corrosion rate, called Dose response functions in the literature, do not seem to be appropriate for Icelandic conditions. This shows that the impact of corrosive agents in different environments is not always comparable. Attempts to model Icelandic dose response functions have not given good results so far since the measured corrosion varies greatly with time and the concentration of salinity is not yet sufficiently mapped. The content of salinity and $\mathrm{SO}_{2}$ concentration is measured in a few places to obtain knowledge about which values to expect. These measurements will be made periodically, and over a limited time. A model for estimating salinity in the air needs to be worked out for use in future estimates of corrosion.

\section{Yearly average temperatures}

Even though Iceland is on the $63-66^{\circ} \mathrm{N}$ the weather is moderate because of the Gulf Stream, which warms the ocean and the country. The average annual temperature is between $3-7$ ${ }^{\circ} \mathrm{C}$. The climate is windy with annual average wind speed in Reykjavik being $5 \mathrm{~m} / \mathrm{s}$. In the wintertime it is uncommon in the southern part to have long periods of temperatures below $5^{\circ} \mathrm{C}$. For this reason and the inexpensive geothermal water the need for super isolated houses 
is low. The requirements regarding $\mathrm{U}$ - values in our building regulation are similar or lower than requirements in Norway or Sweden.

\section{Earthquakes, zones and magnitude}

Structural engineers in Iceland have to use Eurocode 8 for all earthquake related design. The earthquake loads to be used in Iceland are defined in six zones, i.e. $0,05 \mathrm{~g}, 0,10 \mathrm{~g}, 0,15 \mathrm{~g}, 0,20 \mathrm{~g}$, $0,30 \mathrm{~g}$ and $0,40 \mathrm{~g}$. The zones are shown on maps (one for the whole country and a more detailed one for the Reykjavik area) and values for all villages and towns are also provided in a table.

\section{Volcanic eruption}

Even if we do not design for volcanic eruptions there is always a risk of eruptions even in building areas as we have experienced in resent years in Vestmannaeyjar (1973) and at the energy steam power station Krafla ( around 1980) in the northern part of Iceland. We have though been lucky and no lives have been lost in these latest events.

\section{NATURAL RESOURCES}

\section{Hot water supplies / steam power plants}

Icelandic geothermal resources have traditionally been divided into two main groups depending on reservoir temperatures. The high temperature reservoirs have temperatures exceeding $200{ }^{\circ} \mathrm{C}$ and low temperatures reservoirs have temperatures less than $150{ }^{\circ} \mathrm{C}$ at $1 \mathrm{~km}$ depth. So far 28 high temperature areas have been discovered in Iceland. They are all situated within the active volcanic rift zone that crosses the country from southwest to northeast. Their total thermal capacity is estimated to be more than $10^{20}$ joule (or useful $20 \mathrm{TWh}$ per year). Only a small portion is now already being used.

As an example we may look at Nesjavellir power plant. The Nesjavellir field at the Hengill area is one of the largest high temperature areas in the country some $25-30 \mathrm{~km}$ east of the capital at the lake Thingvellir. The power plant there uses the cold water from the lake and consists of the following five sub-systems all of which have separate functions.

Cold water supply (the lake)

Geothermal fluid supply (deep down in the earth)

Heating and treatment of cold ground water

Transmission pipeline to Reykjavik (the $1870 \mathrm{l} / \mathrm{s}$, up to $97{ }^{\circ} \mathrm{C}$ water flows by gravity to the reservoir tanks on a hill at the city edge)

Electricity generation from the steam

\section{Hydro power}

In Iceland we have many rivers and mountain lakes that make it possible to produce electricity. The useful capacity is estimated to $30 \mathrm{TWh}$ per year. Several dams and hydropower plants have been built during the past 60 years. Even though we have to take environmental issues and assessments more and more into account we are still building dams and producing more energy to use in aluminium production and in the everyday live.

Karahnjukavirkjun, the largest project ever in Icelandic history is now being constructed in the eastern part of the country. The dam will be one of the biggest dams in Europe, $730 \mathrm{~m}$ long and the height will be $193 \mathrm{~m}$. The tunnel from the reservoir to the power plant will be 53 $\mathrm{km}$ and about $100-200$ meters under the ground in the mountains. Six turbines will produce $115 \mathrm{MW}$ each. 
Even with all our power plants and industry production only about $17 \%$ of the practical electrical production capacity had been harnessed in 2003.

\section{ICELANDIC BUILDING REQUIREMENTS FOR ADVANCED BUILDINGS}

\section{U - values}

The Icelandic building regulation contains requirements regarding U-values for buildings. Due to the surprisingly moderate climate in Iceland the requirements are not very demanding as table 4.1 shows. These requirements have been increased with each major modification of the building regulation during the past 25 years.

\begin{tabular}{lll}
\multicolumn{3}{l}{ Table 4.1 U-values, $\left[\mathrm{W} / \mathrm{m}^{2} \mathrm{~K}\right]$} \\
\hline Structure & $\mathrm{T}_{\mathrm{i}}>18^{\circ} \mathrm{C}$ & $18{ }^{\circ} \mathrm{C}>\mathrm{T}_{\mathrm{i}}>10^{\circ} \mathrm{C}$ \\
\hline Roofs & 0,2 & 0,3 \\
\hline Walls & $0,3-0,4$ & 0,4 \\
\hline Windows & 2,0 & 3,0 \\
\hline Doors & 3,0 & - \\
\hline Floors & 0,3 & 0,4 \\
\hline
\end{tabular}

\section{Deflection requirements}

Deflection requirements in the building regulation vary for the intended use of the building. The requirements are rather complicated but very useful for the entrepreneur and the house owner. Three categories are defined:

Category A: Strong requirements such as for residential housing and office buildings.

Category B: Moderate requirements such as for better industrial buildings and summer cottages.

Category $\mathrm{C}$ : Weak requirements such as for agricultural buildings and low quality industrial buildings.

\section{THE BUILDING PRACTISE TO DAY AND EARLIER}

Concrete is the main building material in Iceland (about $75 \%$ of walls are built from concrete). This is understandable since Iceland is not forested and hence there is no timber production in the country. Timber used in construction is now imported mostly from Scandinavia, Russia and the Baltic area. In resent years timber element houses have though been imported from many countries. Factory buildings and other industrial buildings are frequently steel structures mostly imported from big producers. Engineers certified by the authorities have to be responsible for the design. Because of the windy circumstances it is very necessary to build airtight houses as concrete houses usually are. It is of course a more difficult task when constructing from timber and steel. It is necessary to design carefully the sections of the building elements as wind and moisture barriers are important for the durability of the elements. Claddings on the outside must also withstand the high wind speeds and other natural forces.

Typical housing in Iceland is family owned and over $60 \%$ of all houses in Iceland have been built after 1970. When calculating the heat loss for "a typical family house" it can be found that at the losses due to transmission and due to air exchanges are about equal if the latter amounts to about 1,1 exchanges per hour. The old tradition in house building in Iceland was 
a concrete wall with isolation on the inside. However during last 25 years the use of ventilated claddings and isolation on the outside are becoming increasingly popular. The houses are most frequently cast with the windows placed directly in the concrete forms before casting and the same applies to roof trusses. The experience shows that this method can have long durability in the relatively cold climate in Iceland. The district heating system is generally without circulation. The hot water is pumped from the ground and after the process of removing the oxygen other gasses from the water it is pumped into the heating system to the customers. The hot water is used for heating and other household use. At last after the energy has been used it goes into the sewage system. This is both an effective and an inexpensive way to heat buildings.

\section{CONCLUSIONS}

From experience we have learned to design buildings to withstand natural forces like strong winds, earthquakes, snow loads and corrosion loads. History shows this design to be very successful. However, several snow avalanches with fatalities have occurred during the last decades. A regulation was issued a few years ago with requirements regarding planning and construction in avalanche areas. Furthermore, it contains requirements regarding protective barriers in already built areas for the protection of the population.

When building of other materials than concrete it is necessary to respect the natural forces and design building elements carefully. Designers and entrepreneurs must use their skill and knowledge to achieve satisfactory durability without expensive repair and maintenance work over the life span of buildings. All detailing for the construction work with emphasis on wind and vapour barriers must be of good quality to assure satisfactory outcome.

\section{REFERENCES}

Gunnarsson, Árni, et al, 1991 Nesjavellir Geothermal Co-Generation Power plant, Hitaveita Reykjavíkur.

B. Marteinsson and J. Sigurjónsson, March 2002, Corrosion of metals - mapping of the environment in Iceland. 9th International Conference on Durability of Building Materials and Components, Brisbane Convention \& Exhibition Centre, Australia.

Landsvirkjun, Reykjavik, Information on The World Web, www.lv.is

The Icelandic Building Regulation, 1998, Ministry of environment. 


\title{
An emerging Faroese Energy Policy
}

Vilhjálmur Nielsen, M.Sc. Eng, PhD, Director and Senior consultant, ENplan, vini@enplan.dk

\begin{abstract}
Faroe Islands has a cold temperate ocean climate with small temperature variations over the year and an average temperature highly influenced by the Gulf Stream surrounding the islands. The influence of the Gulf Stream is though diminishing with the heights leaving the new development areas of e.g. Tórshavn that can be as much as 150 to 200 metres above sea level in a significantly different climate.
\end{abstract}

This article gives an overview of the energy consumption on the Faroe Islands and the issues addressed in the emerging energy policy debate that will result in a draft policy to be discussed in the parliament in autumn 2005. This is the first attempt to establish a Faroese energy policy putting the development of energy efficiency standards for residential and other buildings and building energy demonstration projects on the agenda. The article calls for international cooperation and inspiration on such programmes to be implemented on the Faroe Islands.

\section{INTRODUCTION}

In 2004 the Faroese government initialised the development of an energy policy and electricity supply act. The initial political debate on the energy policy took place in parliament in February 2005 stating that specific targets should be set on the use of renewable energy and that energy savings should be encouraged. A draft energy policy is to be discussed in the parliament in autumn 2005.

Energy has been low on the public and political agenda for a long time and only limited actions have been taken on energy savings. The low priority is shown by the fact that few analyses have been conducted on energy issues and no national energy standards and norms are in official use. The lack of data is also the reason why the Faroese Government asked Denmark to declare a territorial exclusion to the Faroe Islands on the ratification of the Kyoto Protocol.

The entry into force of the Kyoto Protocol puts this position on the political agenda and a decision is expected in autumn 2005. Analyses on the Faroese emissions and effects of the ratification of the Faroe Islands shows that the $\mathrm{CO}_{2}$ emissions are 11\% higher in 2003 than in 1990 (Lastein, 2005), and that emissions could be expected to be 20-32\% higher in 2010 relative to 1990 if no actions are taken to reduce the emissions (Nielsen, 2005). The study also states that the costs of compliance with an $8 \%$ reduction target that is the EU average can be achieved with only marginal effects to the economy.

\section{CLIMATE AND GEOGRAPHY}

Faroe Islands is benefiting from a location surrounded by the Gulf Stream that is influencing all parts of the country and keeps the average annual temperature in Tórshavn as high as 6.5 ${ }^{\circ} \mathrm{C}$ and the average minimum winter temperature at $1.2{ }^{\circ} \mathrm{C}$. On the other hand the average maximum summer temperature in Tórshavn is only $12.8^{\circ} \mathrm{C}$. The position at $62{ }^{\circ} \mathrm{N}$ gives long days in the summer, with two months where the lighthouses are not in use and short days in the winter. 
The Faroese climate is characterised as temperate oceanic climate. As Arctic climate is defined by the warmest month not exceeding $10{ }^{\circ} \mathrm{C}$ and the coldest not exceeding $0^{\circ} \mathrm{C}$ while the temperature is exceeding $10^{\circ} \mathrm{C}$ in less than 4 months to define sub arctic climate (Wonders, 2001) around $80 \%$ of the Faroese land area can be characterised as arctic or sub arctic. The built area has historically solely been close to sea level preferably on places with good wind conditions. This has changed in the last 20-30 years due to scarcity of land, so that newer buildings can be in more windy places and/or at higher altitudes up towards 200 metres above sea level in sub arctic climate.

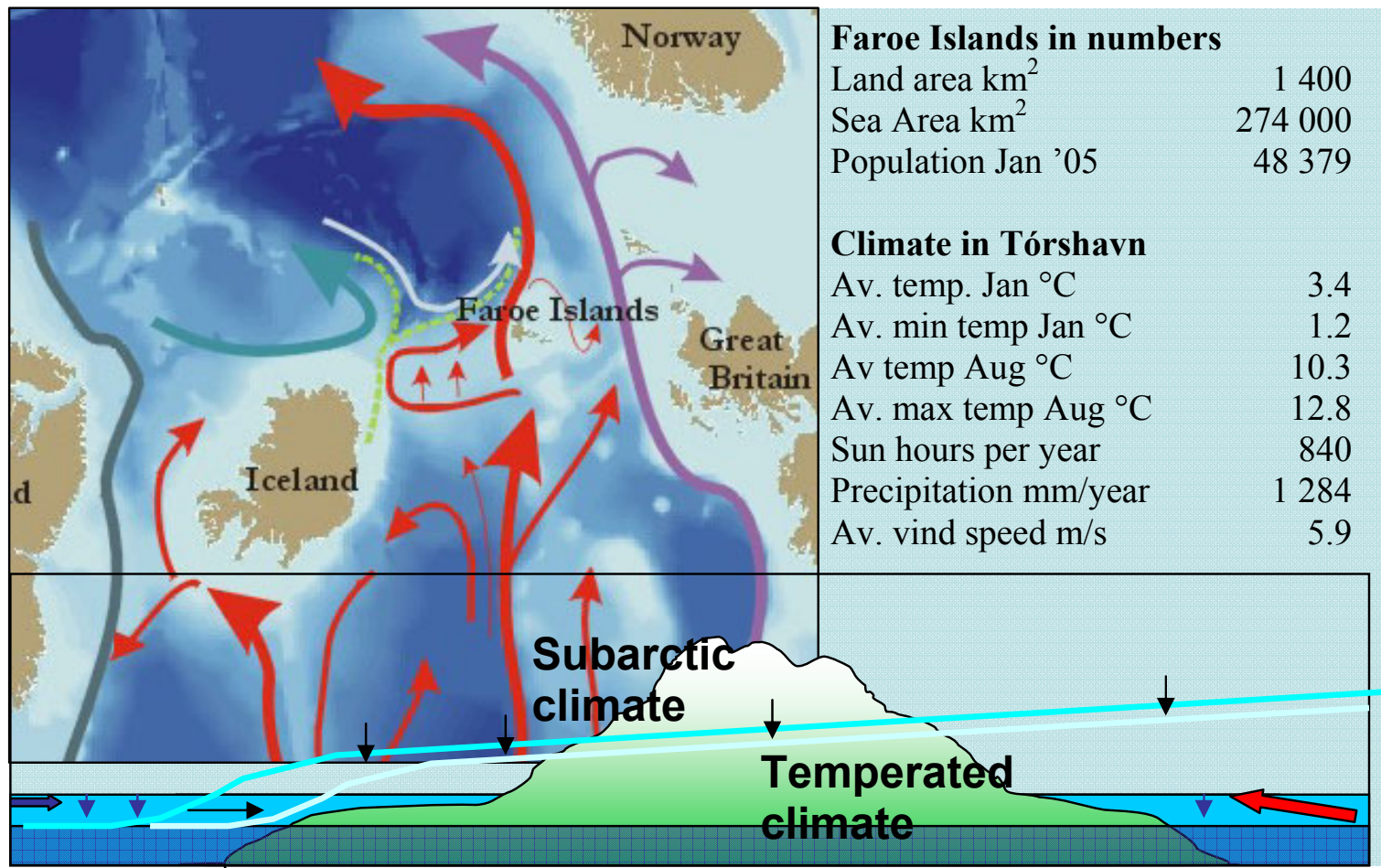

Figure $1 \quad$ General and climate data on the Faroe Islands (Illustrations: Mortensen, L; Data, Hagstova Føroya)

\section{THE ENERGY SYSTEM}

The Faroese energy system is dominated by the use of oil, where the only other significant energy source is hydropower that contributes to around $35 \%$ of the total electricity production of $250 \mathrm{GWh}$. This equals $5000 \mathrm{kWh}$ per person. Wind energy contributes to as little as $3 \%$ of the total electricity production but will increase to $5-6 \%$ in the coming years as the current turbines will be supplemented with new turbines at other locations to learn more on the dynamic effects on the electricity grid. There are two main electricity grids in the country as the main area is covered by one system and Suðuroy has its own system.

There is a district heating system in the newly developed part of northern Tórshavn that receives its heat from the waste incineration plant of Tórshavn supplemented with oil fired boilers. The system covered 441 dwellings and 14 commercial consumers in 2003 and will expand as the area is further developed. The supply lines can be extended to the main power station north of Tórshavn that could supply around 1000 houses with its heat capacity of 20 MW that is currently not utilised. This could give a basis for expanding the district heating network further. 
A breakdown of the total oil consumption in 2003 of 227 kton $(9.5 \mathrm{TJ})$ on user groups as shown in figure 2 below shows that $33 \%$ goes to the fishing fleet but also that heating of residential houses and public and commercial buildings together contributes to $23 \%$ of the oil consumption - energy that essentially is used for space heating and heating water.

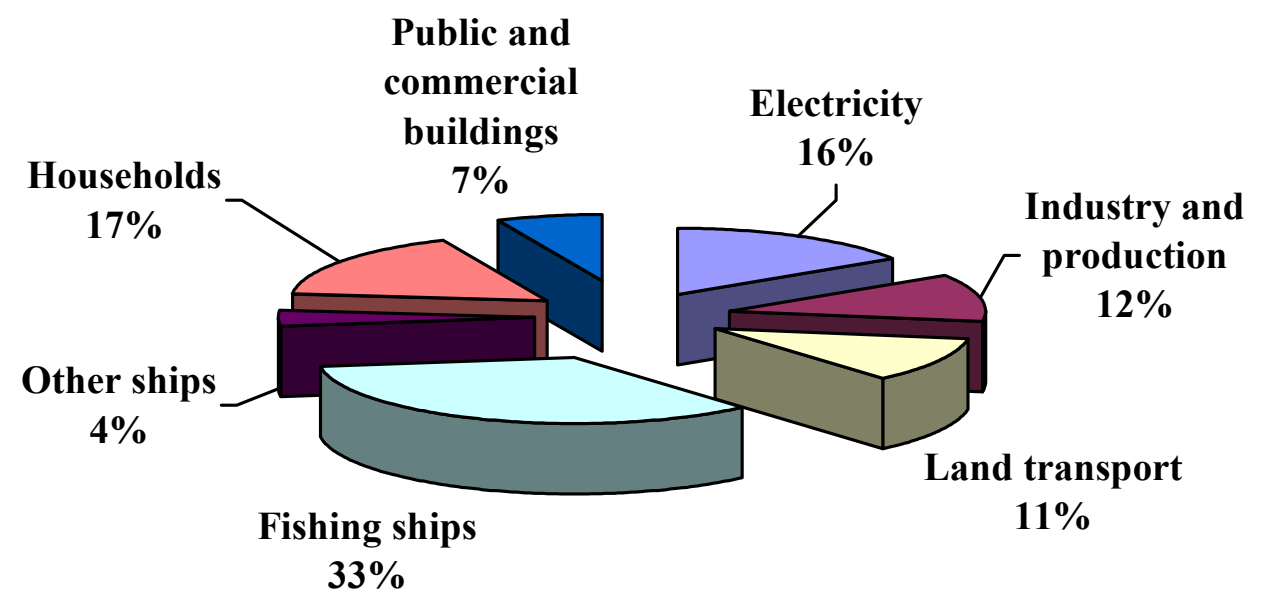

Figure 2 Oil consumption in 2003 broken down on end user groups (Lastein, 2005).

\section{THE HOUSING SECTOR}

The dominating form of residential buildings on the Faroe Islands is single family houses that are individually heated with oil-fired central heating systems. From the 60'ies a typical residential house is a two-storey house with the basement made of cement above ground and the main storey made of wood as shown in figure 3 although also all-cement buildings are common. In the last 25 years also multi family houses have been built and are e.g. used directly as a mean of creating a wind barrier on new housing areas in the Northern part of Tórshavn.

The registration of buildings in the Faroe Islands is limited to the registration on municipality level related to the construction permit. There is thus no central public registry of buildings on the Faroe Islands. Except from the building regulations of each municipality and the fire protection regulations there are no official requirements or guidance on construction. A Guidance was made in 1984 (Orkuráðið) with inspiration from the Danish Building Regulations from 1982 and Norwegian regulations. It is unclear how this guidance is used today, but it can be anticipated that the architects and engineers have knowledge of the Danish standards and regulations. There is however no indications that calculations have been made on the optimal insulation standard although calculations are presented on the oil savings by increasing the insulation standard. Neither have there been any systematic information gathering nor demonstration projects on low energy houses.

The debate in the Faroese Parliament showed political support to the following elements of an energy policy:

- Utilisation of renewable energy shall be increased

- Waste heat shall be utilised 
- Energy efficiency shall be increased

- Energy prices shall reflect the environmental impacts

- Independent energy producers shall have access to the electricity grid.

- Information, Development and Research.

For the housing sector this will result in the development of energy standards of residential and other buildings.

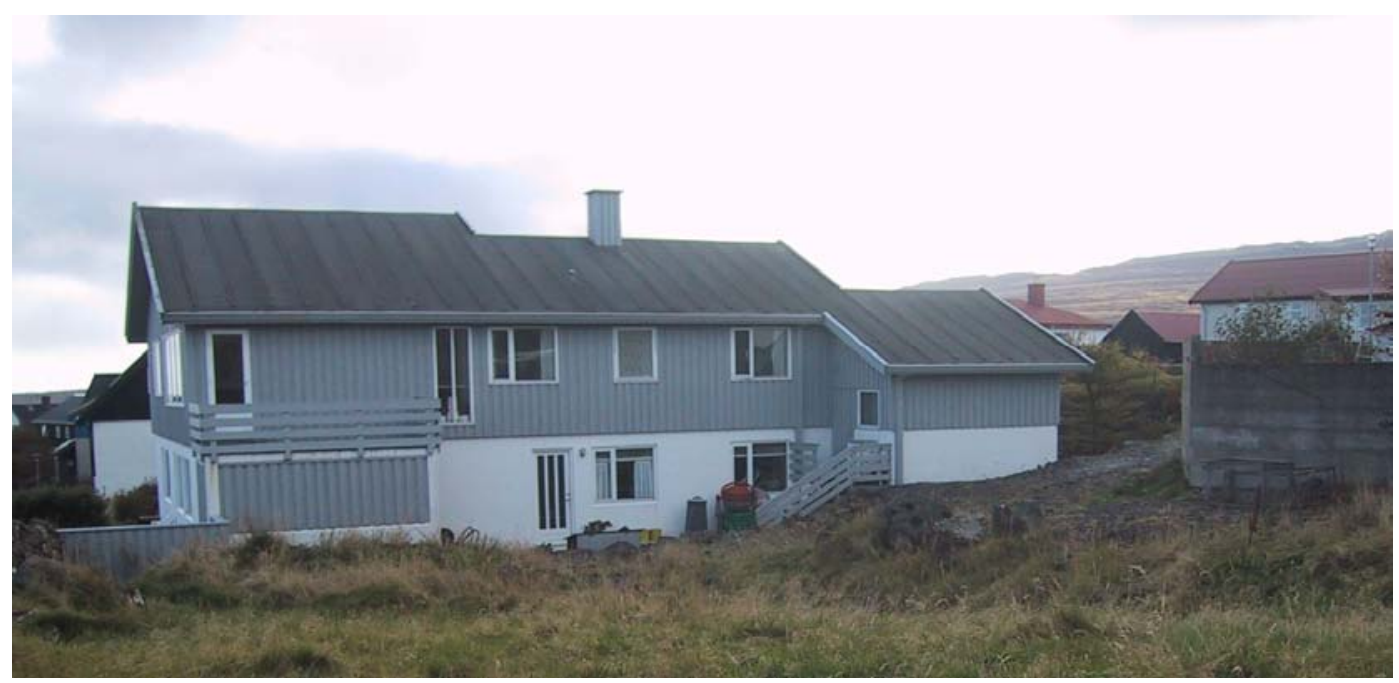

Figure 3 A typical Faroese single family house of a type that has been the dominating style since the 60 'ies with full basement made of cement and the main living floor made of wood. It is common to expand the living area to the basement when the children want more space and privacy.

\section{RECOMMENDATIONS AND CONCLUSIONS}

There are large unutilised potentials for energy savings and renewable energy on the Faroe Islands. They can be utilised in order to lower the dependency of fossil fuels and thus also minimising the costs of imported energy in accordance with the coming Faroese Energy Policy.

It is though clear that more structured knowledge on existing houses and energy calculations are required in order to make the right priorities in the effort to reduce the energy consumption in the housing sector. This goes along with energy management strategies in larger buildings where knowledge and experiences on energy reductions can be shared between institutions.

A first step toward this will be to make investigations on the different types of houses on the Faroe Islands and the different aspects that influence the energy consumption. This can then be the starting point for demonstrations on retrofitting of existing houses.

Also the establishment of demonstration low-energy houses would be of relevance and would give data and experiences that would be of benefit to researchers in other countries. Inspiration and suggestions on how such a demonstration and monitoring programme can be established will be highly appreciated. 


\section{REFERENCES}

Hagstova Føroya - Faroese Statistics - Data obtained from their open databases at www.hagstova.fo

Lastein, L. 2005. Útlát av veðurlagsgassi i Føroyum, Food, Veterinary and Environmental Agency, Faroe Islands

Nielsen, V. 2005. Støða Føroya í mun til Kyoto-frumskjalið, Ministry of Interior, Faroe Islands

Orkuráðið (Faroese Energy Council),1984. Bjálvingarleiðbeining.

Vinnumálaráðið, 2004. Fyrsta ávegis álit i arbeiðinum at orða uppskot til yvirskipaðan orkupolitikk og elveitingarlóg (Fyrst preliminary memorandum on a proposal for an energy policy and electricity supply act).

Wonders, William C.: Arctic and subarctic islands, in AccessScience@McGraw-Hill, http://www.accessscience.com, DOI 10.1036/1097-8542.049000, last modified: August 13, 2001.

\section{ACKNOWLEDGEMENTS}

Mortensen, Lis; Head of department, Faroese Geological Survey, for providing illustrations of the sea streams and climate

Weihe, Tórálvur; Architect, for providing photo of typical Faroese residential house and information on current and past construction praxis. 


\title{
Low-energy buildings in Norway
}

Tommy Kleiven, M.Arch. PhD, SINTEF Technology and Society, Department of

Architecture and Building Technology.tommy.kleiven@sintef.no

\begin{abstract}
The Norwegian Parliament has initiated a shift in the way energy is produced and used in Norway. As a part of this, national goals have been established of increasing the annual use of hydronic heating based on new, renewable energy sources, heat pumps and waste heat. The Norwegian Government has recently announced a supplementary goal of increasing the annual district heating capacity, and indicated that funds will be made available to subsidise the development of the district heating net. In order to promote district heating, the authorities also open for mandatory installation of hydronic heating systems in new buildings in areas where district heating potentially could be developed.
\end{abstract}

But, parallel to this focus of the Norwegian government, there is a general trend in the market towards more energy-efficient solutions in buildings. This drive will be even stronger when the new EU-directive on the energy performance of buildings is being put into force in 2006, including stricter energy requirements for new buildings and a mandatory energy certification system for all buildings being sold or rented.

By improving the thermal performance of new buildings, the need for space heating can easily be reduced to a minimum, and in Germany and Austria, highly insulated "passive houses" without need of heating systems are competitive in the market. In recent, Norwegian development projects, the space heating demand has been shown to be as low as 1500 to 2000 $\mathrm{kWh}$ per year per dwelling. Due to this very low heating demand, the developers have questioned the sensibility of installing rather costly hydronic heating systems in the building in order to make it possible to connect to the district heating net.

This emerging conflict between the developer's drive towards low-energy buildings, and the authorities' goal of expanding the district heating grid, raises some questions about the interaction between the supply side and demand side of the energy system, and the choice of optimum energy solutions for future low-energy and "passive" buildings.

\section{BACKGROUND AND STRATEGIES FOR LOW-ENERGY BUILDINGS}

\section{Energy use and environmental impact}

Even if the required insulation thickness in walls, roof and floor has doubled four times in the last 35 years in Norway, the specific energy use per square meter floor area in commercial buildings has not decreased, but increased. There are several reasons for this, but important factors are:

- Increased use of glazing as an architectural feature (transparency, lightness)

- Higher internal loads due to more lighting and equipment

- Due to higher airflow rate requirements, more energy is used for conditioning the air (heating, cooling) and for moving the air (fans). 
- Due to strict temperature control, and increased heat gains (solar and internal) it is common to cool buildings mechanically in Norway. This has further increased the energy demand in modern buildings.

In particular, high ventilation rates increase the energy demand substantially. This is not only caused by the design of the ventilation system itself, but is caused by the total concept of modern buildings. The design of a modern building is often dominated by the concern for room scheme layout, building logistics, and building design. Afterwards, on a later stage in the process, the indoor climate is taken care of by the heating system and the mechanical ventilation and cooling system. This often results in high energy consumption for heating, cooling and ventilation.

Energy use for equipment, lighting, cooling and fans has to come from electricity, which is becoming a limited resource in Norway. If the electric energy demand keeps increasing new electricity plants has to be built, with the associated negative environmental impacts. In the future, it is therefore necessary to reduce the total energy demand in buildings, and particularly lowering the electricity demand.

\section{Investment, maintenance, running costs and service life}

The investment costs for technical installation have increased steadily since world war 2, and they now comprise typically $25-35 \%$ of the total building costs. In retrofitting projects this number is substantially higher, typically $50-60 \%$.

The maintenance and running costs for technically advanced installations are also large. In a modern building with advanced climatisation (heating, lighting, ventilation and cooling) a technically competent person has to monitor the running of the system more or less continually. Added together with costs for mandatory and random maintenance and energy use, the total running and maintenance costs are rather high.

The lifetime of technical installation is typically around 15-25 years. This is well below the normal lifetime of the building itself, which typically is $50-100$ years. After this time period, a total retrofitting of the installations are required, which is often followed by a retrofitting of the rest of the building. A total retrofitting of a building after such a short time, is hardly preferable in an environmental perspective.

\section{Historical and present use of "passive-buildings"}

Before mechanical ventilation, cooling and artificial lighting were common in buildings, many natural and passive techniques were used for climatisation of the building. Examples of such techniques are: stack driven natural ventilation, active use of window ventilation, large room volumes/high ceilings, use of high thermal mass, smart window and window frame design for maximising daylight utilisation and limited direct solar gain.

In the last decades, many of these techniques have come to new use in order to reduce or eliminate mechanical ventilation and cooling, and to reduce the demand for artificial lighting. However, owners and users of modern commercial and institutional buildings have higher standards for comfort, indoor air quality and to some degree energy efficiency. Uncritical copying of the passive techniques used in old buildings is therefore not recommendable. 
There are several reasons, however, to review passive techniques in modern buildings:

- The theoretical undestanding of natural and passive techniques is much better today than earlier.

- Modern personal computers and software makes it possible and realistic to simulate and predict passive techniques.

- Advanced computerised control systems make it possible to control and optimise passive techniques to achieve good thermal comfort, acceptable indoor air quality and low energy use.

\section{Future building trends, new directives and passive-house standard}

The use of natural and passive techniques for climatisation of buildings have become more widespread throughout Europe the last decade. Both in the Scandinavian countries, especially Sweden and Denmark, and in other European countries such as Germany, Austria, Switzerland, the UK, The Netherlands and Belgium, "passive buildings" have become popular among building owners and users. This trend will probably strengthen as the demand for sustainable buildings with low energy use increases in the future. This drive will be even stronger when the new EU-directive on the energy performance of buildings is being put into force in 2006.

Table 1 The table show the suggested maximum energy use for various building types in Norway. The new EU-directive on energy performance of buildings will be put into force in 2006 in Norway.

\begin{tabular}{cc}
\hline Building category & Total energy use $\left(\mathbf{k W h} / \mathbf{m}^{\mathbf{2}}\right.$ year) \\
\hline Domestic houses & 150 \\
\hline Block of flats & 130 \\
\hline Kindergarten & 160 \\
\hline Offices & 160 \\
\hline Schools & 130 \\
\hline Hospitals & 320 \\
\hline Nursing homes & 210 \\
\hline Hotels & 230 \\
\hline Restaurants & 230 \\
\hline Sports centre & 180 \\
\hline Commercial buildings & 270 \\
\hline Cultural centres & 170 \\
\hline Light industry, workshops & 160
\end{tabular}

The passive house standard is developed by Dr. Wolfgang Feist http://www.passivehouse.com There are several criteria a house has to fulfil to be defined as a passive house:

- Net specific energy use for heating $<15 \mathrm{kWh} / \mathrm{m}^{2}$ year

- No energy use for cooling

- Average U-value for windows including window frames $<0.8 \mathrm{~W} / \mathrm{m}^{2} \mathrm{~K}$

- Specific fan power (SFP) $<1.5 \mathrm{~kW} / \mathrm{m}^{3} / \mathrm{s}$

- Tightness building envelope: $\mathrm{n}_{50}<0.6$ air changes/hour

- Energy use for lighting $<7 \mathrm{kWh} / \mathrm{m}^{2}$ 

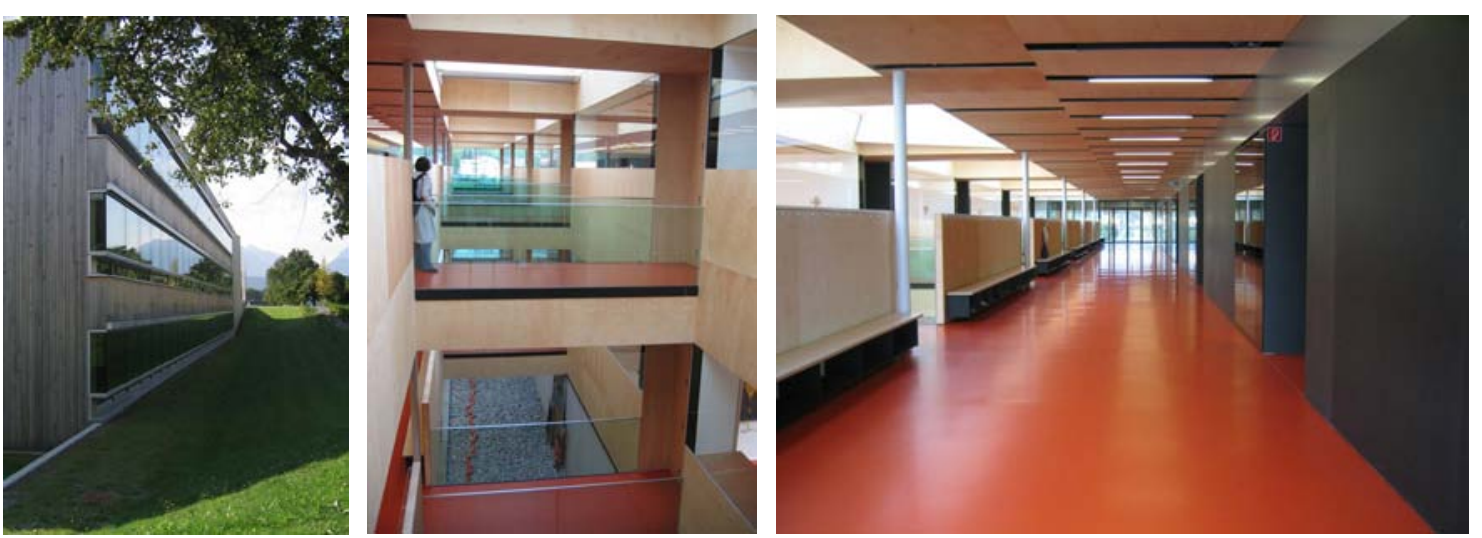

Figure 1 The Weiler school in Klaus, Austria is one of the first buildings to take the "passive house" concept to other building functions than domestic buildings.

\section{Strategy for designing low energy buildings (SINTEF)}

A design strategy based on the Kyoto pyramid developed at SINTEF Technology and Society, Dept. of Architecture and Building Technology divides the de design process in 5 steps with step 1. as first priority, step 2. second priority and so forth :

1. Reduce heat losses (super insulated and tight building envelope. Efficient heat recovery of the ventilation air in the heating season).

2. Reduce the use of electrical energy (energy effective lighting and equipment. Low pressure drops in the ventilation system, low SFP).

3. Utilisation of solar energy (optimum window orientation, atrium/sun spaces, proper use of thermal mass for passive heating and cooling, solar collectors, photovoltaics).

4. Display and control the energy use (Demand controlled lighting, cooling, heating and lighting. User feedback on energy use).

5. Choice of heating system and energy carrier (solar collector, heat pump, district heating, firewood, gas, electricity).

\section{CONCLUSION}

This emerging conflict between low-energy buildings, and the authorities' goal of expanding the district heating grid and water based heating systems in buildings have raised some delicate questions about the interaction between the supply side and demand side of the energy system. The continuous development of better low-energy and passive buildings are however not likely to stop up. There is a need to find the optimum energy supply solutions for future low-energy (and passive) buildings. 


\section{Moisture and Indoor Climate in Buildings}

Carsten Rode, Assoc. Professor, car@byg.dtu.dk

Casper Roland Hansen and Ragnar Karbech Mouritsen, M.Sc. students

Department of Civil Engineering, Technical University of Denmark.

\section{ABSTRACT}

The outdoor climate in Greenland is very dry. But it is also a cold climate, and in order to avoid draft, dwellings in Greenland may be ventilated only at a rather minimal level. Together with indoor moisture generating activities, such as cooking, and because of insufficient exhaust ventilation systems, the indoor humidity level can in some buildings be unacceptably high - despite of the dry outdoor conditions. This may lead to indoor climatic problems or decay of materials in exterior building constructions. The paper and presentation will give some outline of the problem and measures taken to investigate the conditions in some buildings in Sisimiut - including the new low-energy house.

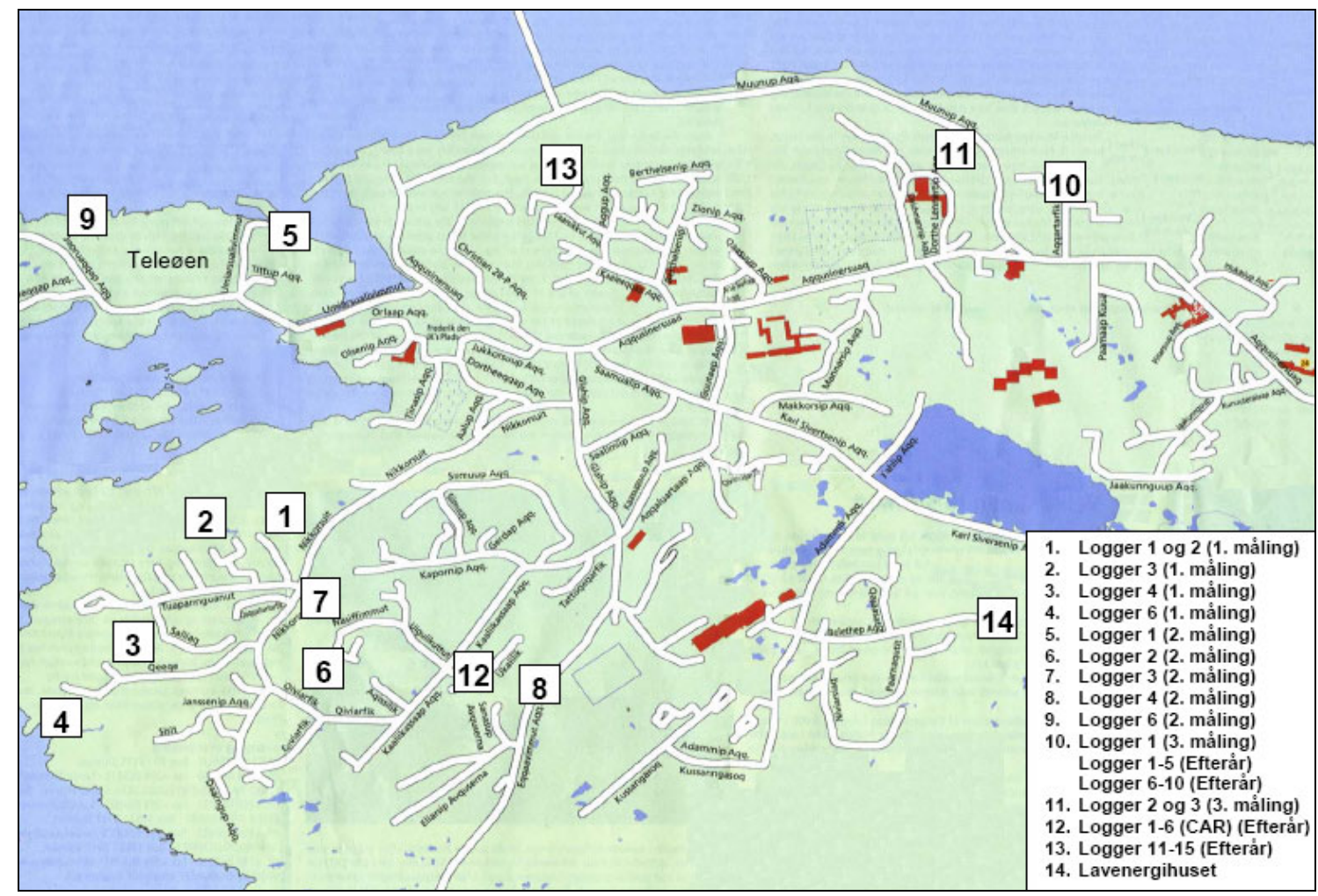

Figure 1 Map of Sisimiut with locations of buildings in which measurements of indoor humidity conditions have been carried out in the period: Summer 2004 to the winter 2004-2005. No.14 is the location of the low-energy house.

\section{BACKGROUND: MOISTURE CONDITIONS BUILDINGS}

\section{Some Physics about Moisture in Indoor and Outdoor Air}

Atmospheric air always contains some amount of water vapour. But the amount that can be held in the air depends very strongly on the temperature. At $20^{\circ} \mathrm{C}, 1 \mathrm{~m}^{3}$ of air contains a 
maximum of $17.3 \mathrm{~g}$ of moisture. Normally, indoor air has only about half of this maximum amount - or even less. But every time the temperature drops by about $10^{\circ} \mathrm{C}$, the maximum water vapour content is halved. Thus, if warm air that contains some humidity is cooled or gets in contact with cold surfaces, condensation may form on these surfaces. Even before condensation occurs, the so-called relative humidity (RH) of the air may become very high ${ }^{1}$. Relative humidity higher than about $80 \%$ in air, on building surfaces, or within building materials and structures will often lead to the onset of processes which are harmful to the indoor climate or cause decay of materials - e.g. by microbiological activity (by fungi or bacteria).

Indoor air can be understood to be the same as the outdoor air that is vented into our dwellings preferably at a rate of no less than a $50 \%$ change of the air per hour. Inside the building the air is polluted by the residues of our activity: From the human body this is mainly $\mathrm{CO}_{2}$ and water vapour, but activities such as cooking, smoking and other things release fumes, and finally some more moisture also comes from cooking, bathing and drying of clothes. Therefore, there should be a proper balance between the "pollution" generated, and the amount of fresh air supplied. Too high air change, on the other hand is not desirable either - it may cause draft and too high energy consumption for heating.

Problems associated with high indoor humidity can be avoided by keeping the indoor humidity production low, by ensuring sufficient supply of fresh and drier air from the outdoors, and by avoiding that warm, humid air gets in touch with significantly colder building parts, such as near cold bridges or on cold panes and frames of windows etc.

Some causes of so-called bad indoor climate are related to conditions of high humidity. It is generally know from studies in Sweden and other Nordic countries, that the further to the north buildings are located, the more pronounced seem to be health related problems associated with damp buildings (Bornehag et al., 2001).

\section{Conditions in Greenland}

The outdoor air in Greenland is generally very dry because it so cold that it is unable to hold much moisture. However, the following reasons exist which may cause fairly high indoor humidity conditions:

- To avoid draft, it is not unusual that inhabitants seal off fresh air vents and ventilation shafts as much as possible.

- Many dwellings do not have a mechanical exhaust hood over the kitchen furnace.

- Preparation of food is often by long-time boiling of meat, so a lot of steam may be generated.

- Facilities for outdoor drying of clothes in winter are not always the best - therefore it is done indoors in a way that causes evaporation to the air.

- There are many hunters in Greenland. Preparation of the prey is a humidity releasing activity that often takes place in within the dwelling.

Thus, it is not unusual to see some indoor moisture problems in Greenlandic homes. This is the general impression one gets when speaking with people in the local community. However, the scientific evidence is scarce, so the extent and possible consequence of the problem is not known.

\footnotetext{
${ }^{1} \mathrm{RH}$ is defined as the actual amount of water vapour in the air in relation to the maximum possible at the same temperature.
} 
A consequence of moisture problems will often be the growth of mould. However, it is likely that this will not be the case in Greenland since the conditions for germination of mould are not very good: Mould normally requires a relative humidity of about $75-80 \%$ or more, and a temperature above approximately $5^{\circ} \mathrm{C}$ to grow. There are not many places present in the ambient or within buildings in Greenland where both the temperatures and humidity levels are optimal for mould growth. The number of mould spores in the ambient environment of Greenland can be anticipated to be rather low.

Another moisture related indoor climatic problem is house dust mites. However, house dust mites require a relative humidity of about $45 \%$ or more to thrive. This is also not a common condition in homes in Greenland.

It may be assumed that most moisture related problems in Greenland are associated directly with the moisture itself, e.g. condensation or frost occurring in cold areas. In building components, the condensation and frost problems may cause problems with freeze/thaw passages. In the indoor environment, the wet surfaces may collect dirt, and if the temperature is high enough there may some biological activity (mould or bacteria) in these areas as well.

\section{INVESTIGATIONS IN GREENLANDIC HOMES}

In order to get some idea about the extent of moisture problems in private homes in Greenland, students from DTU's course on Arctic Technology (Hansen et al., 2004) have installed some data loggers in a small number of buildings in Sisimiut (see Figure 1). The work was begun in 2004, and is followed up in 2005. In cooperation with the Greenlandic social housing administration, INI, some data loggers of the type HOBO H08 have been installed in particular rooms of some of the homes. The data loggers, which have the size of a match box (see Figure 2), are able to measure and store temperature and relative humidity measurements every half hour in a $2 \frac{1}{2}$-month period.
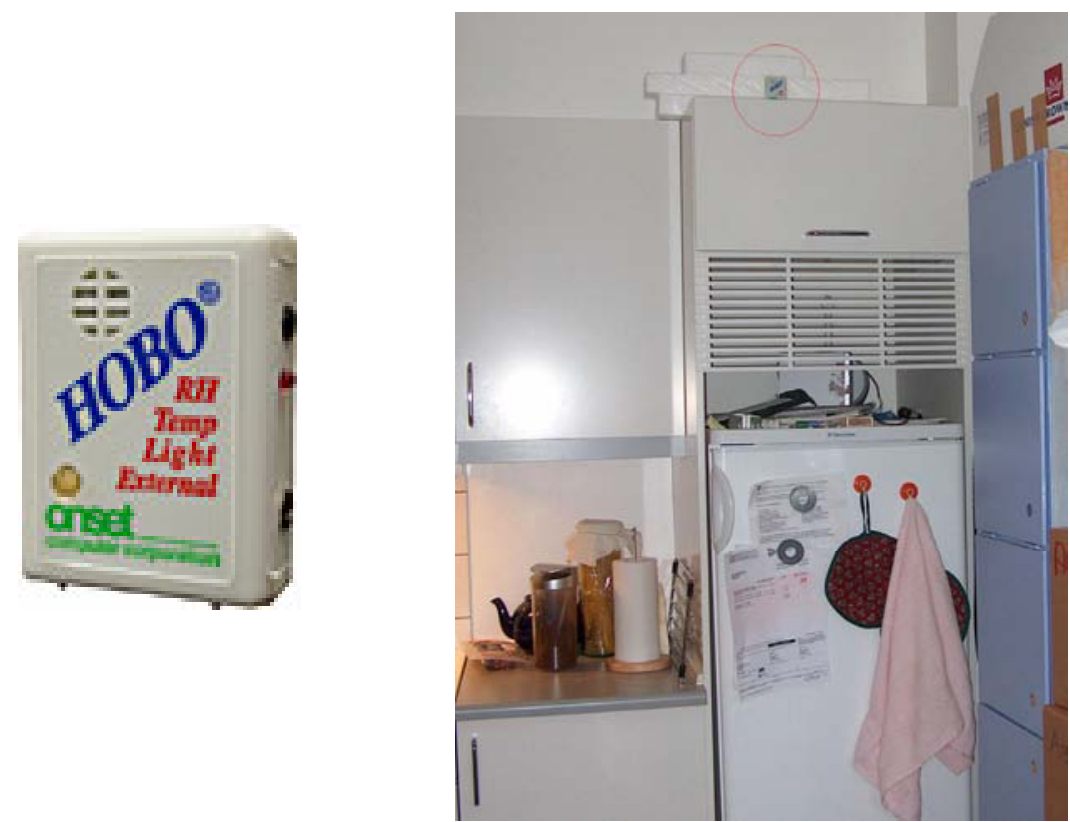

Figure 2 The HOBO Data logger and its placement in a kitchen.

An example of one of the more prolonged measurements with the HOBOs is the measurement series carried out in the house shown in Figure 3. The house is $125 \mathrm{~m}^{2}$, and is the residence of 
a family of two adults and two children. The house has an exhaust fan over the kitchen furnace, and the family reports to have some good habits, such as drying their clothing outdoors whenever the weather permits. The vapour content measured with the HOBOs is shown in Figure 4 together with results from meteorological measurements of the outdoor humidity in the same period.
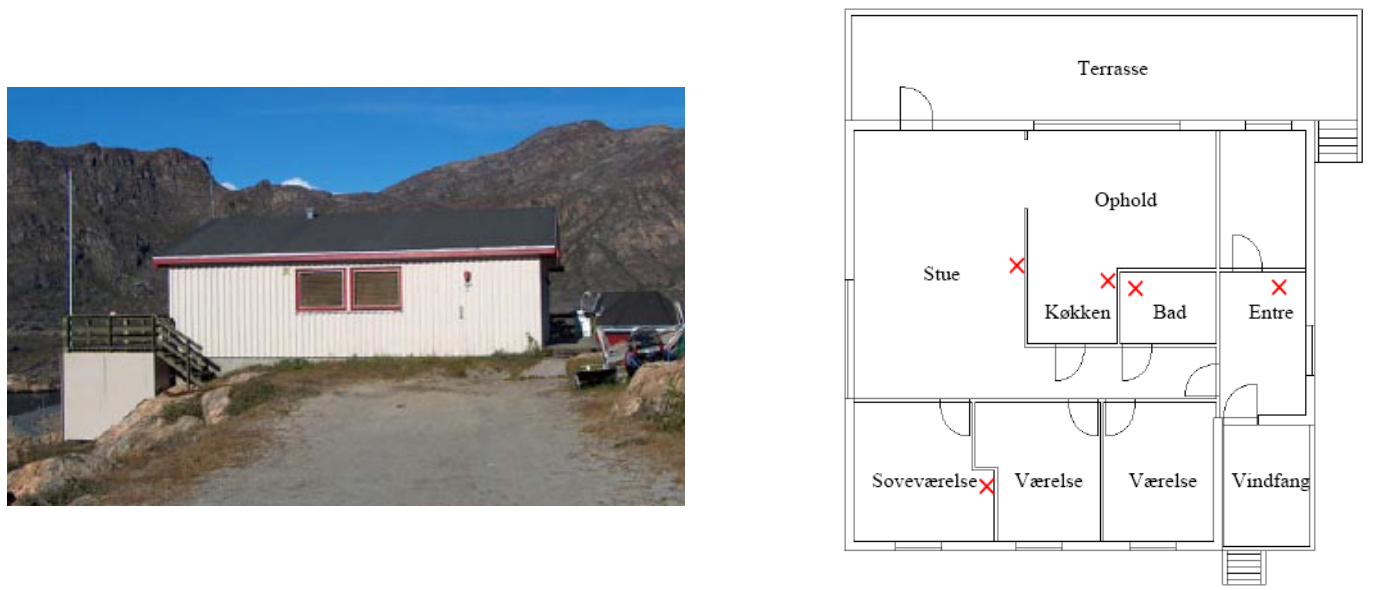

Figure 3 Picture and plan of a house where extended HOBO measurements have been carried out.

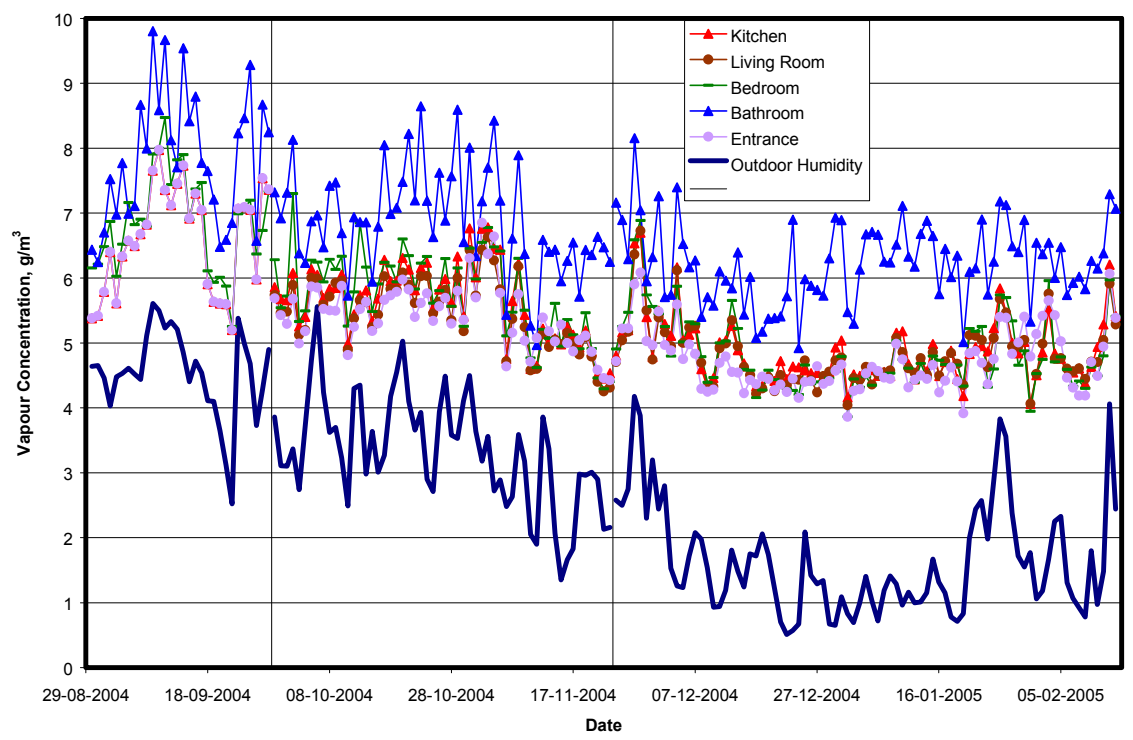

Figure 4 Indoor and out vapour content for the house in Figure 3 (the vertical lines separate three different measurement sequences)

As expected, the vapour content is higher indoors than outdoors, but only by about $2.5 \mathrm{~g} / \mathrm{m}^{3}$, which is a quite acceptable condition for dwellings. Only the bathroom has a somewhat higher vapour concentration. It may also seem that the difference between indoor and out vapour content is somewhat higher in the winter months. However, this could also be a result of the HOBOs not being able to measure the low indoor relative humidity seen in winter (< $25 \% \mathrm{RH})$. All in all, this appeared to be a house with a good indoor climate and no indoor humidity problems. 


\section{INVESTIGATIONS IN THE LOW ENERGY HOUSE}

The new low energy house in Sisimiut is built with an insulation thickness which is larger than usual, and it has a mechanical ventilation system with heat recovery, which is not a common solution in Greenland. It is of interest to document that this highly profiled house will have a good indoor climate, and that moisture problems do not occur in the constructions. The building has therefore been equipped sensors that register the moisture and temperature conditions in a number of locations.

Two types of sensors, shown in Figure 5, are used:

- Wood dowels measure the moisture content by registering the electric resistance between two nails in the wood. Partly, this is also a test of whether this very conventional, rather simple and handy measurement technique can be used under the dry and cold conditions in Greenland. The probes are read manually with a special $\Omega$-meter. The house is equipped with seven of these sensors.

- Twenty small Sensirion sensors measure the relative humidity and temperature, and the results are logged on a computer. This more advanced measurement system should be able to measure in a wider temperature and humidity range than the wood dowels.

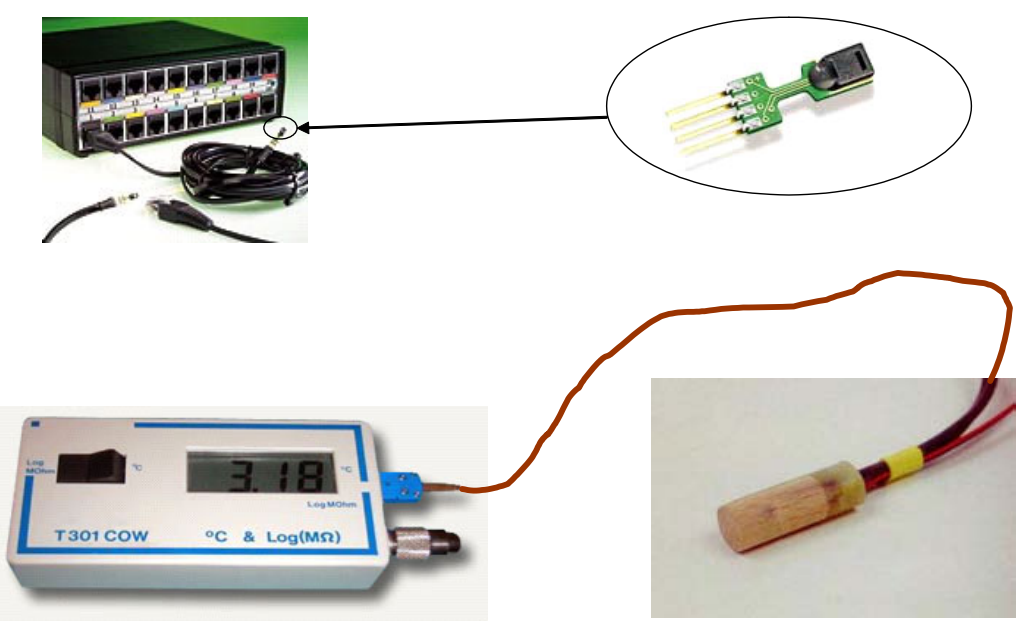

Figure 5 Sensirion temperature and humidity measurement system (top), and wooden dowels for electrical measurement of moisture content (bottom).

The location of the sensors is shown in Figure 6. The measurements started in the end of February 2005. Some of the results for the first two weeks of measurement with the Sensirion system are shown in Figure 7. It is planned to register the conditions for at least a two year period. The measuring system will remain in the house, and thus may continue as a study object for students and researchers from the Building and Construction School and the Centre for Arctic Technology..

\section{CONCLUSION}

There is still a lack of documentation on indoor climatic conditions and possible moisture problems in Greenlandic homes. The activities which have been initiated and outlined in this presentation should help to uncover these conditions, and as needed, should lead to guidelines for appropriate design and use of buildings so they are best suited for the severe climatic loads in Greenland. 


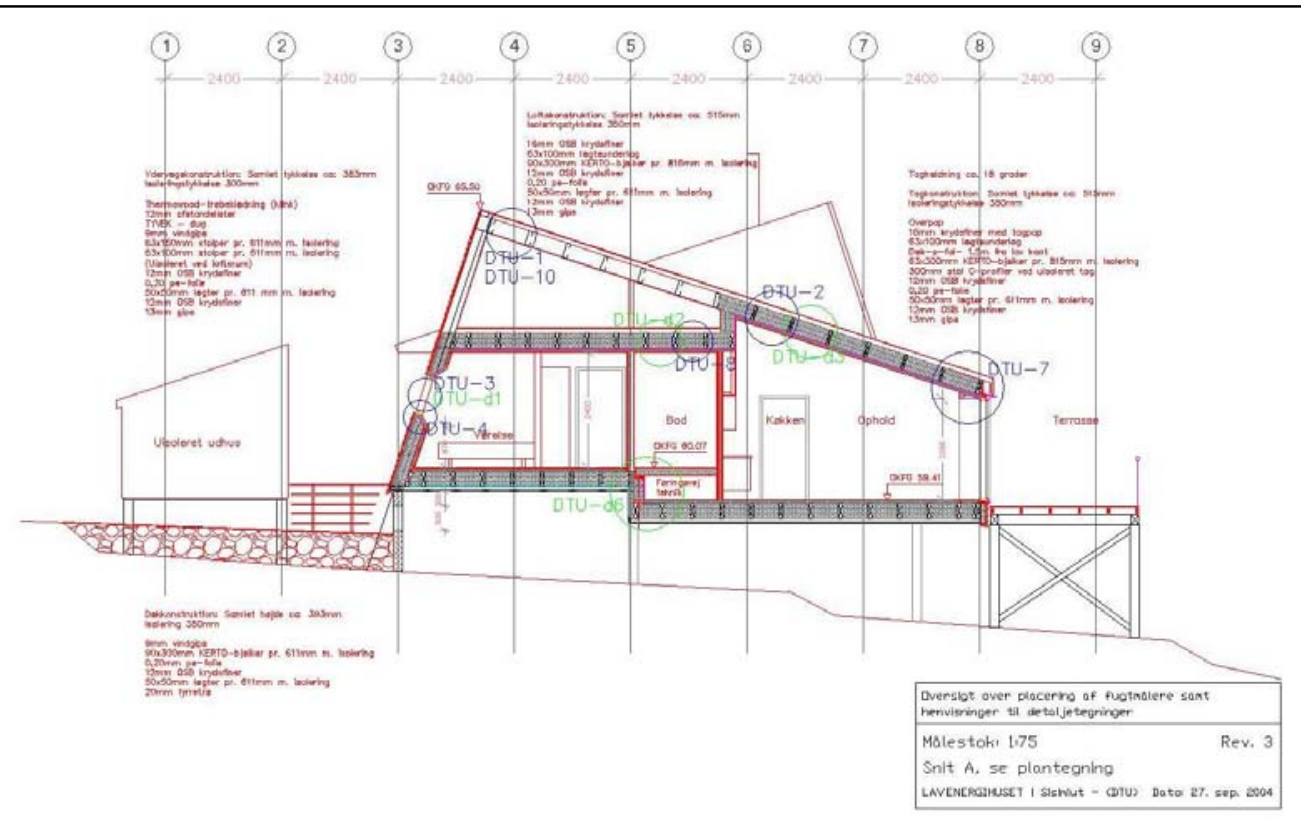

Figure 6 Cross section of the low energy house with marked location of the moisture sensors.

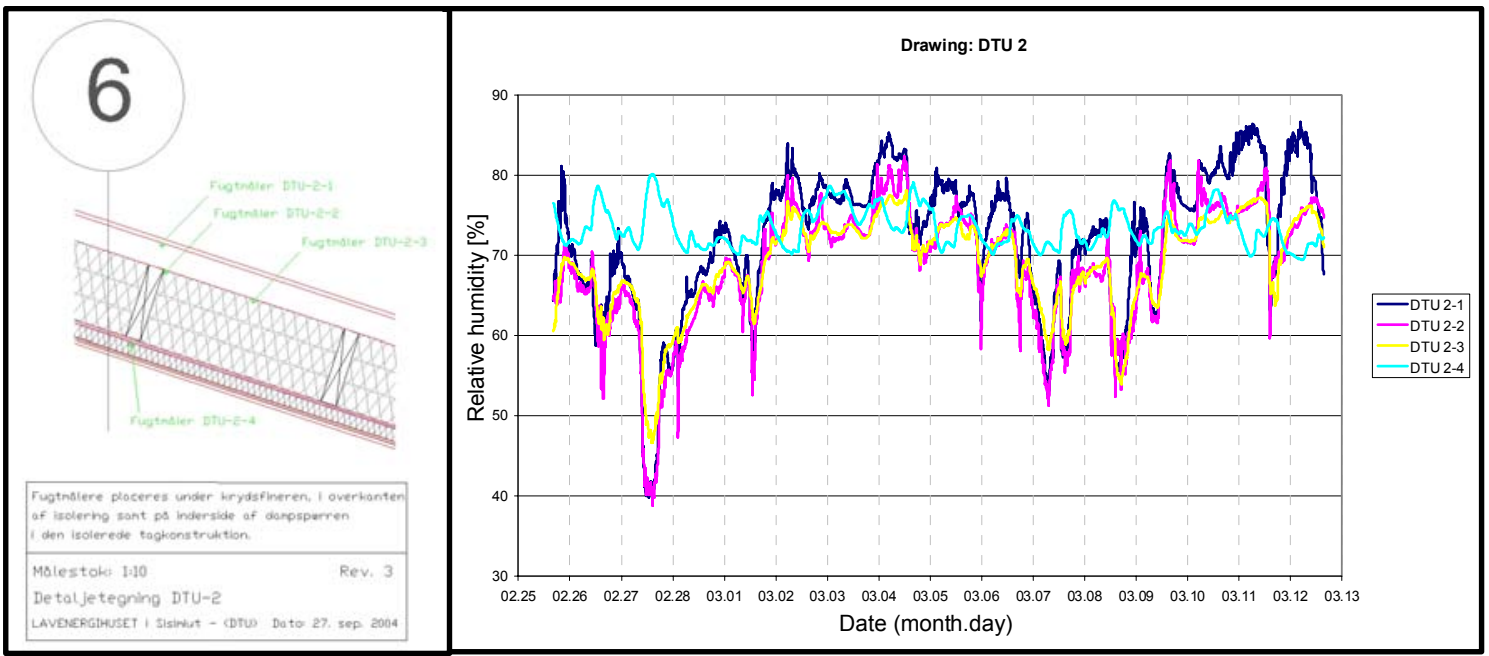

Figure 7 Relative humidity measured at four locations in the sloped roof with Sensirion sensors.

\section{REFERENCES}

Bornehag, CG., Blomquist, G., Gyntelberg, F., Järvholm, B., Malmberg, P., Nielsen, A., Pershagen, G. (2001) Dampness in Buildings and Health: Nordic interdisciplinary review of the scientific evidence on associations between exposure to "dampness" and health effects, NORDDAMP. Indoor Air 2001;11:72-86.

Hansen, C.R., Johansen, H.M. and Jensen, G.D. (2004) Fugtmåling i lavenergihuset, Sisimiut. Project report from participation in course on Arctic Technology, Department of Civil Engineering, Technical University of Denmark. 


\title{
Renovation of Old Residences in Greenland
}

\author{
Ruben Svendsen, Architect, Boligselskabet INI
}

\section{PREFACE}

The work with the principal renovation of the public owned housing stock in Greenland has been going on since 1989 .

In order to get a general view of the extent of renovation jobs a renovation plan was carried out in 1991 for the several-families houses of the Home Rule build before 1982.

Through the following decade around 1000 dwellings were renovated and 500 had larger partial renovations made in the housing stock owned by the Home Rule.

In addition to this there have been carried out renovations of the Home Rule buildings and municipal buildings through appropriations to special maintenance, 60/40 renovations and through the dwelling-departments' maintenance budget.

\section{'RENOVATION PLAN 2000'}

In connection with the wok concerning a renovation-fond in the winter 1998 and 1999 there was indicated a need for a re-estimating the 1991 renovation plan, since this had not been changed since 1991.

At the end of 1999 the introductory presentation of a plan from 'A/S Boligselskabet INI' on how the work with handling the need for renovations of dwellings in Greenland can be handled, 'Renovation Plan 2000', was approved.

Dwellings in settlements was left out since the 'Bygdeboligregistrering' (settlement dwelling registrations) from 1996 could be seen as normative for the renovation need in dwellings in the settlements.

At the end of 2000 the registration of dwellings was completed for the 'Renovation Plan 2000 ' at the same time as the 'A/S Boligselskabet INI' finished the work with maintenance plans for the dwelling departments.

The housing stock registered in the 'Renovation Plan 200' can be split into three main parts older several-families houses with a need for principal renovation, newer several-families houses with a need for partial renovation and one-family- and double-houses.

In Greenland there hardly were build several-families houses before 1960. A large part of the several-families houses which are build as actual apartment houses in Greenland are build from the mid-sixties till the end of the seventies. The houses were often built from the same concept or from a variation of the standard house which the 'GTO' developed for apartment houses.

The concept was typically a standard block of dwellings with two to five storeys. The block was usually built as a part of a built-up area with several identically blocks where the bottom storey usually was used as heating central, workshop, caretaker and the like. 
From the beginning of the eighties it can be said that the 'wave' of building 'low and close' was generally accepted in Greenland and the models of how to build several-families houses had to be different from the ideals ruling in the sixties. Many of the built-up areas from the eighties in the category several-families houses is in a building technical matter a lot like onefamily houses.

After the work with the state estimation of public owned rented housing with estimated renovation need the following principal conclusions can med made:

There are around 3,600 dwellings with a need of principal renovations, from this number the rented housings of the Home Rule several-families houses accounts for 3,334.

From the 3,334 rented housings of the Home Rule several-families houses with a need for renovation Nuuk accounts for 1,538 dwellings. It is concluded that the need for renovations in Nuuk is a separate large problem.

The conclusion of the 'Renovation Plan 2000' was that there on public apartment houses is a renovation and modernisation need of around 2.1 billions DKK split on principal and partial renovation and if the renovations should be completed within a reasonable period the Home Rule must set aside 120 millions in 2001 prices a year till 2017 to renovations of dwellings with a following scaling down and expected ending of the renovation work in year 2021.

Till now it has not been possible to set aside the required amount of money in order to solve the work within the expected timeframe.

In connection with the control of the renovation jobs is given to 'Direktoratet for Boliger og Infrastruktur' (the Directorate for Dwellings and Infrastructure) the directorate has proposed the following sector plan for the dwelling renovation. The proposal is sent to the Home Government.

\section{SECTOR PLAN OF RENOVATION OF THE HOME RULE'S APARTMENT HOUSES}

The sector plan only consists of those of the Home Rule's apartment houses which have been estimated to be principally renovated. These blocks of flats are planned to be renovated over a period of 20 years until 2025.

The renovations of one-family houses, terraced houses and other blocks of houses are done in connection with the dwelling service and will be financed over the same appropriation as the projects which specifically have been admitted to the sector plan.

It will be necessary to adjust the sector plan continuously in agreement with the actual need for renovations.

In the planning there is attached importance to that the dwelling renovation in each town happens in a continuously process so the gained experience can be used in the following projects. Furthermore it is aimed at keeping the expenses in fixed prices around 80 millions DKK a year including the post 'different smaller renovations'. 
The stated budgets for each project in the sector plan are prices pr. square meter which are build on experience. One must expect prices between 7,000 and 9,000 DKK $/ \mathrm{m}^{2}$.

The appropriations are given in the sector plan as frame appropriations. By a more flexible estimated revenue it is possible to start certain parts of the projects and leave others for later - or change the project in a way which allows a economically or technically secure renovation to start without the whole project needs to be treated in a new Budget which will lead to delays.

\section{WHAT IS BEING RENOVATED?}

Primarily the renovations are done to assure the life of the building. This means roofs, concrete constructions, outer walls, windows and outer doors are renovations or exchanged first. For the interior bathrooms, kitchens and installations will be renovated or exchanged first.

There will be some improvements:

Many families purchase washing machines which causes the laundries must close in many towns. This means that the bathrooms are made larger where possible and possibilities to connect a washing machine are made. Hereby the risk of water damage - because of unregulated connections of washing machines in living rooms - are reduced.

Mechanical ventilation with a constant low draw and the possibility of a more forced draw in bathrooms and kitchens are installed which helps to reduce damage due to damp and to improve the indoor climate.

The kitchens are renovated with more modern kitchen arrangements when changing the kitchen elements.

It is investigated if it will be possible to establish a resort on the balconies within the economical frame.

\section{ENVIRONMENT AND ENERGY}

There will not be systematically additional insulation of the building, since the costs are too high compared to the possible savings. When changing building elements with insulation there will be insulated extra. It is possible to expect energy savings and environment improvements by the following renovations:

- Changing windows to tight low-E windows.

- Changing outer doors to tight doors in a quality which does not cause deformation because of differences in out- and indoor temperatures.

- Renovating roofs and outer walls.

- Adjusting the heating system and mount thermostatic valves.

- Changing to thermostatic controlled mixer tap.

- Changing to water-saving toilets.

In connection with more dwellings changing to freehold it can be expected that the wish for more comfort combined with completely or partly "do-it-yourself" renovations will encourage renovations where energy savings will have a comparatively long refund period. 
In terraced houses - which have been taken over by the residents - there is already a wish of individually measured use of heat and water consumption. There is no doubt that the consumption will decrease when introducing individual settlement according to consumption. In apartment houses is the way the supply pipes are guided preventing individual settlement. When the technique and the administrative procedures are settled it is likely that many residents will ask for an individual settlement according to consumption.

\section{CLOSING}

The economical situation in Greenland does that the dwelling renovations in Greenland are highly focusing on saving the existing buildings from decay. That is the reason why the improvements often will not be made as you see it other places when the process of renovation is on-going.

There is a hope that more privatization of the housing stock will give the necessary capital and desire to improve. At the same time the reduction in the public owned housing stock will make it more manageable for the building owners to improve here.

Appendix: extract from the 'Renovation Plan 2000', 'Building Inspection Report'

\section{BUILDING INSPECTION REPORT}

\section{Department 173 B-1288 Tuapannguit 7. Block Q Nuuk}

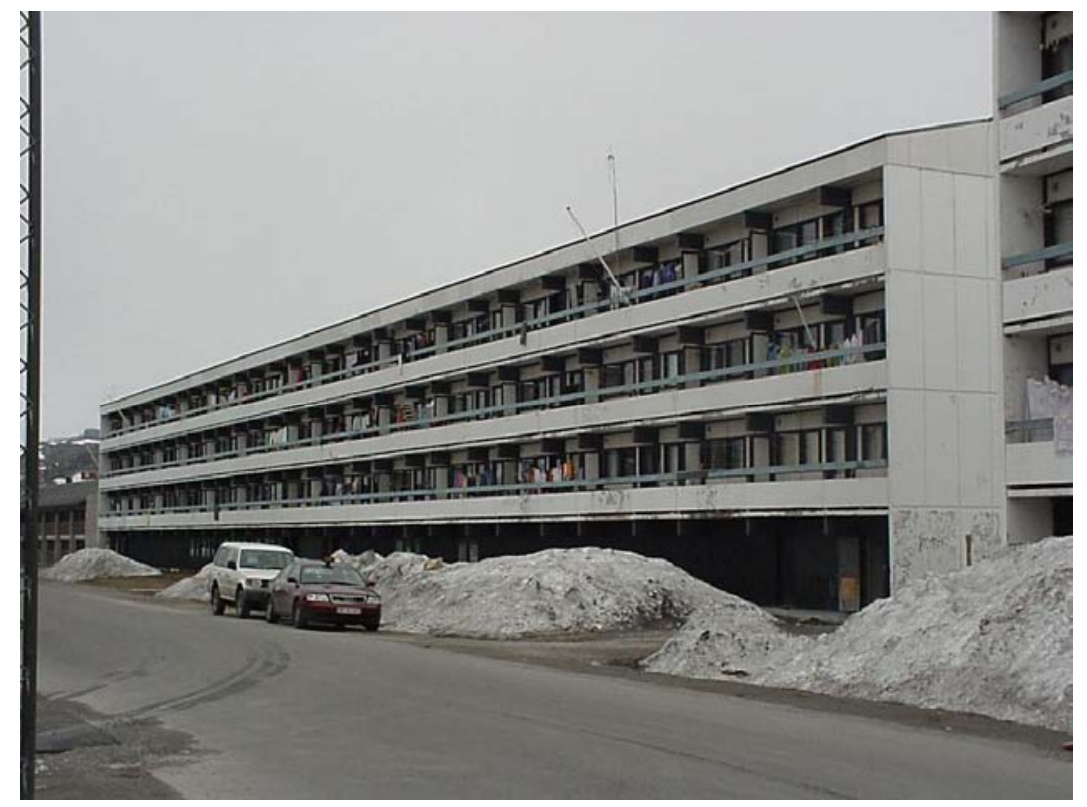

\section{Description of the Building}

Apartment house by Tuapanguit in Nuuk.

The building is built in 1996 following GTOïs standard project for access balcony blocks with lower floor with secondary rooms and depot rooms. Foundations, load-bearing and stabilising walls, floors and access balcony constructions are made of concrete. Façades are prefabricated wooden constructions with fibre cement boards. The lower floor has board covering. Light weight walls incl. bathroom walls are plate-covered wooden framed walls. The roof construction is made of wood covered with steel sheets. The heat supply is district heating. 


\begin{tabular}{lrlr}
\hline Area of the building: & $2,879.56 \mathrm{~m}^{2}$ & Number of tenancies: & 53 units \\
\hline Estimated price: & $24,476,260.00 \mathrm{DKK}$ & Building-group: & 4 \\
\hline
\end{tabular}

BUILDING INSPECTION MARKS 100 Building Envelope

\begin{tabular}{|c|c|c|}
\hline 110 & Outer doors & 3 \\
\hline 120 & Windows & 3 \\
\hline 130 & Façade covering & 1 \\
\hline 140 & Roof covering & 2 \\
\hline \multicolumn{3}{|c|}{200 Carcase / Constructions } \\
\hline 210 & Foundations & $\overline{0}$ \\
\hline 220 & Wall constructions & 0 \\
\hline 230 & Floors & 0 \\
\hline 240 & Roof construction & 0 \\
\hline 250 & Balconies / Access balconies & 2 \\
\hline 260 & Insulation & 1 \\
\hline \multicolumn{3}{|c|}{300 Installations } \\
\hline 310 & Heat & 2 \\
\hline 320 & Water & 1 \\
\hline 330 & Ventilation & 3 \\
\hline 340 & Drains & 2 \\
\hline 350 & Electrical-installations & 2 \\
\hline \multicolumn{3}{|c|}{400 Shared areas } \\
\hline 410 & Terrain & 3 \\
\hline 420 & Access conditions & 3 \\
\hline 430 & Shared rooms & 1 \\
\hline 440 & Basement / Crawl spaces & 1 \\
\hline \multicolumn{3}{|c|}{500 Apartmnet, normal maintenance } \\
\hline 510 & Bath & 2 \\
\hline 520 & Kitchen & 3 \\
\hline 530 & Floors & 3 \\
\hline 540 & Living rooms & 2 \\
\hline
\end{tabular}

0 Alright

1 Normal maintenance needed

2 Repairs needed

3 Exchange/renovation needed 


\section{Comments and pictures of chosen building elements}

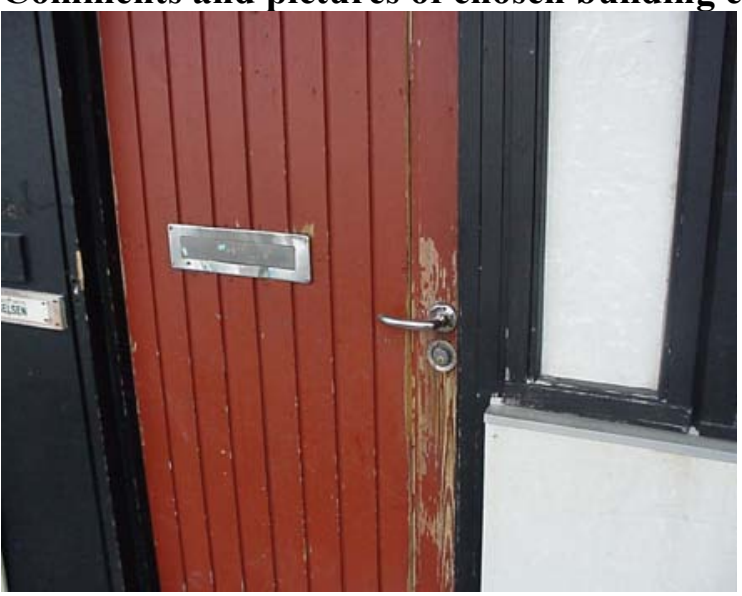

Building element no. 110 Exchange of some doors Building element no. 140 Roof covering is leaking.

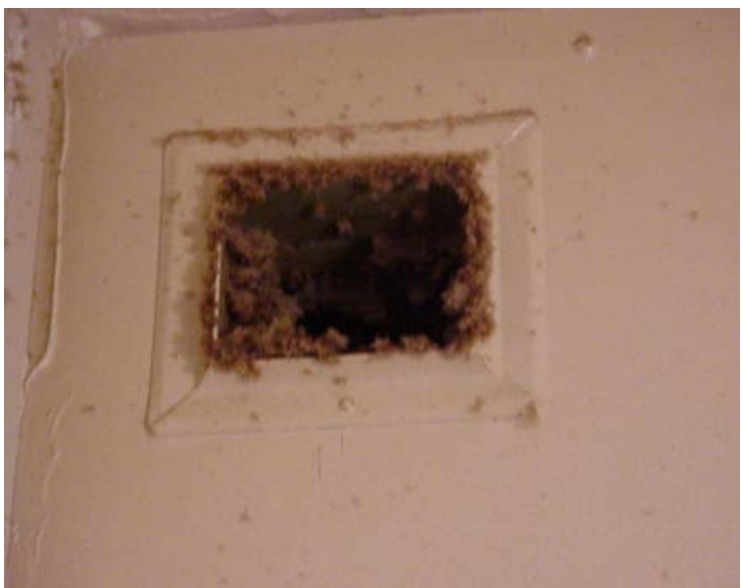

Building element no. 330

Loft ventilations should be established.

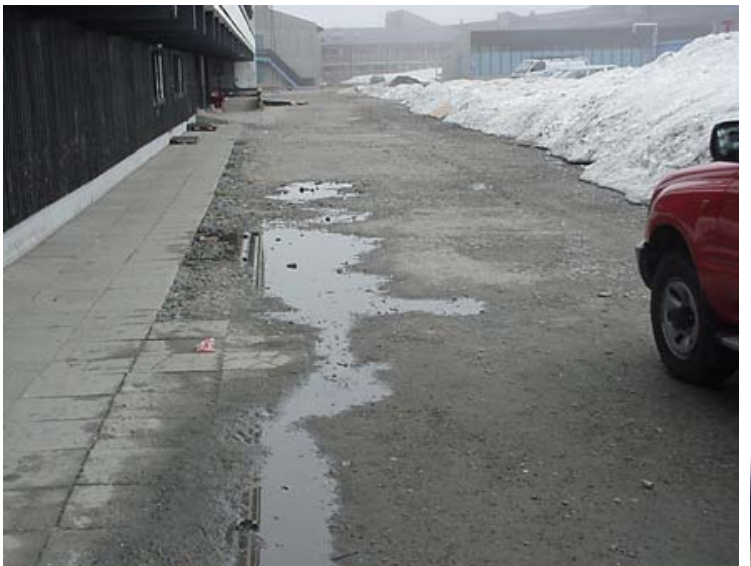

Building element no. 410

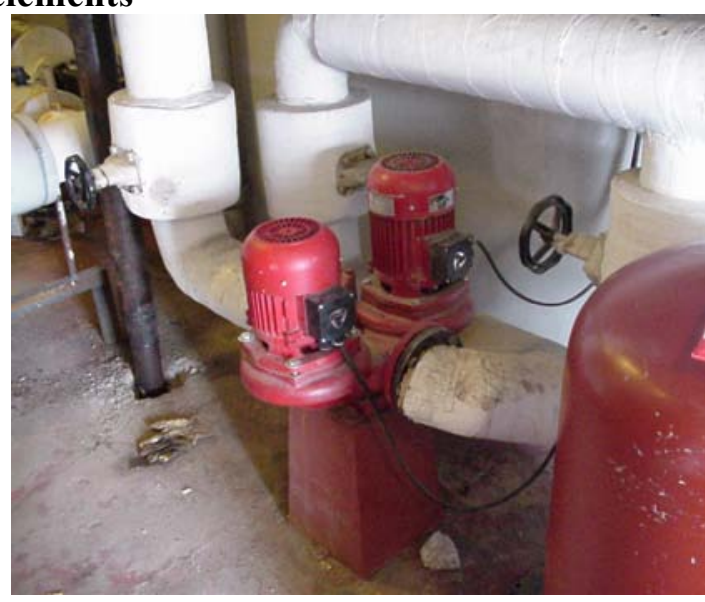

Building element no. 310

Heat pipes are leaking when they are lead through floors. There is poured 100-150 litres on the system every week

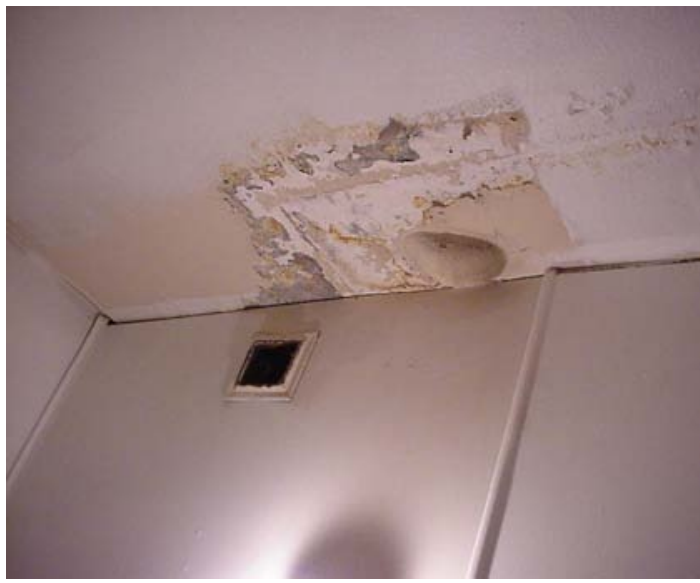

Building element no. 340

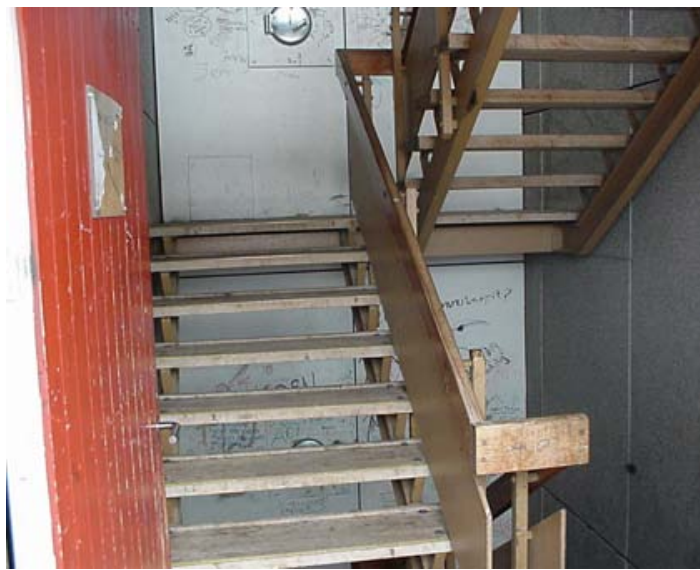

Building element no. 420 


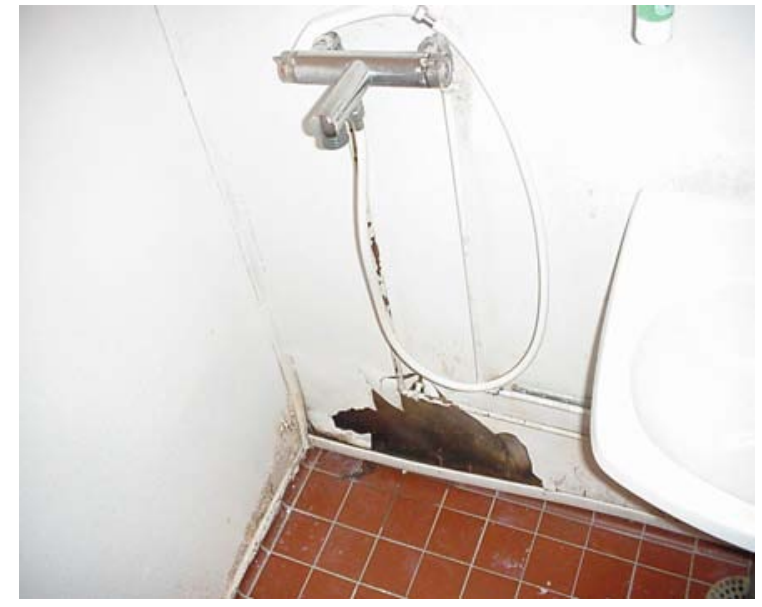

Building element no. 510

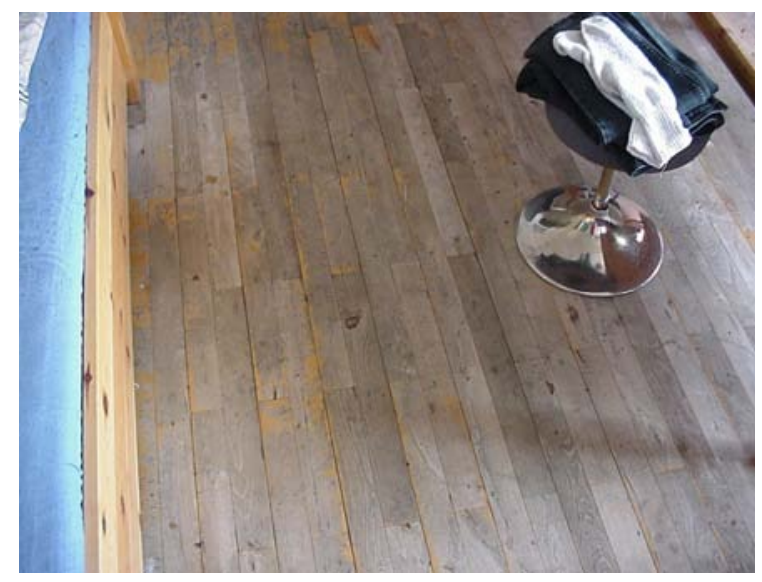

Building element no. 530

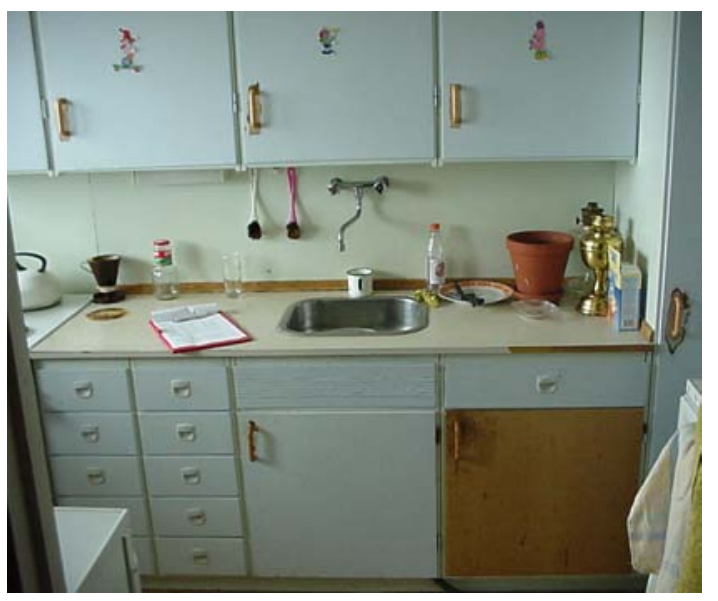

Building element no. 520

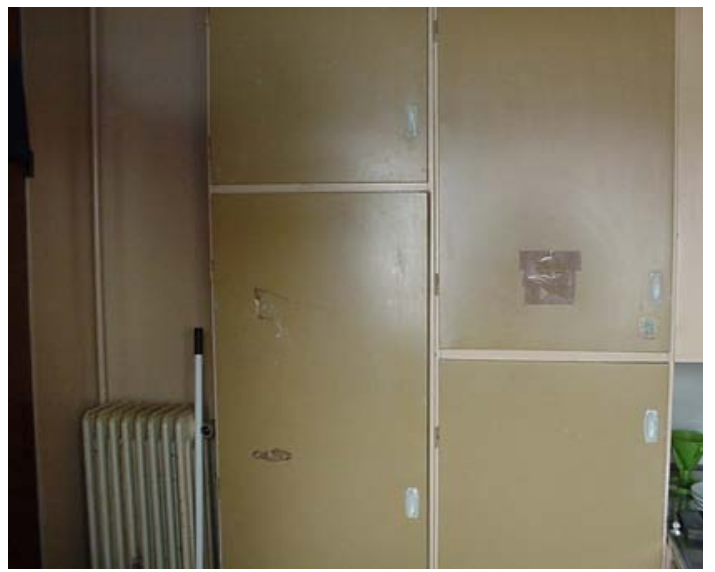

Building element no. 540 


\section{Little Floors Town-Planning Complexes with Energy Protect Building Systems and New Types Concrete}

(work - the winner of VII annual competition PAASN for 2004, Moscow)

Kazakov Jury Nikolaevich, Dr.Sci.Tech., the professor, the assistant to the rector of the St.Petersburg State Architectural Building University, the Chief of the center of tests of building materials, products and designs, the Scientific secretary of SPb of Regional branch, the counselor of the Russian Academy of Architecture and building sciences.

Urgency of a theme of complex research and design-industrial work on a theme: "Little floors town-planning complexes with energy protect building systems (experience of Saint Petersburg in 1999-2003) $»$ low cost and labour input of works is caused by necessity of development new energy protect building systems for little floors town-planning complexes, and also maintenance of the population with habitation, research of new technologies little floors constructions in country zones where determinatives are the reduced terms of erection of buildings. Progressive technologies of housing construction with use of multilayered designs are in 2004 one of the most important directions of increase of efficiency of a cycle in building sphere of Russia.

The analysis of references has allowed to establish, that used single-layered designs from a brick, a tree and concrete blocks do not provide efficiency and profitability of construction that leads to to a significant thickening of walls and weight of buildings. On the other hand, transition to multilayered designs with application of expanded polystyrene, mineral cotton wool and others warm - keepings materials is not always justified because of fragility of polymeric materials at their long operation. Besides their application restrains the insufficient fire resistance, harmful ecological influence on the person and a number of other factors.

The analysis of a condition of manufacture of effective materials has shown high efficiency of cellular concrete. However, their manufacturing is carried out exclusively industrially as a principal cause is the requirement of normative documents on temperature of air not below $15^{\circ} \mathrm{C}$. The given circumstance is caused by features of formation of structure of cellular concrete and limits area of his use, not allowing carrying out manufacture in conditions of building sites. In this connection application of cellular concrete in mass housing construction restrains it enough in high cost of manufacturing industrially.

On objects of construction as a constructive material it is frequently used gas concrete only pressed manufacturing or foam concrete of factory manufacturing.

Therefore there is a problem of development of more perfect technology малоэтажного housing construction with application of designs from a non-conventional material - porous concrete (TPB).

The urgency of a theme of research is defined also by the following factors:

- Modern requirements on increase of heat-shielding properties in external protecting designs of apartment houses;

- Necessity of depreciation of building materials and costs $1 \mathrm{~m} 2$ objects of housing construction; 
- Improvement of operational qualities of a building, increase of fire resistance, reliability and durability of building designs from porous concrete;

- Necessity of the further perfection of technology little floors housing construction with application of non-conventional kinds of concrete, in particular, aerated concrete.

The purpose of work is development new energy protect building systems for little floors housing construction with application of designs from porous and the thermo-vacuum concrete, providing increase of heat-shielding properties of external protecting designs, walls and overlapping and depreciation of construction.

For achievement of the purpose put during research by a group of authors the following problems are solved:

- The technology of preparation and stacking monolithic porous a concrete mix in building conditions little floors housing construction is proved;

- The technology of application of elements of a fixed timbering for erection of monolithic designs from porous concrete mixes is developed;

- Theoretical researches of technical and economic efficiency of application porous concrete in designs of walls and overlapping are lead;

- Introduction and check of efficiency of technological decisions in conditions of building sites are carried out at erection little floors town-planning complexes.

As object of research act little floors town-planning complexes at all stages of a work cycle of their erection.

Object of research is the technology little floors housing construction with use new energy protect building systems - designs from porous (aerated) concrete prepared in conditions of a building site.

Technique of researches: the system analysis and synthesis; mathematical statistics and the theory of probability; kvalimetry; theoretical and experimental researches in laboratory conditions of processes porous creating and aerations of concrete mixes; a theoretical and experimental substantiation of parameters of perfection of technology of reception and application porous mixes and aerated concrete.

Reliability of results of research proves to be true enough of the lead experiments, use of the checked up equipment and standard techniques, a choice of adequate models and methods, application of methods of statistical processing of the information with the help of a computer, sufficient convergence of practical and theoretical results of the research, the constructed town-planning complexes in Saint Petersburg in 2000-2003.

\section{Scientific novelty of research consists in the following:}

1. The technology of preparation porous mixes and aerated concrete in conditions of a building site is proved on the basis of cement, sand, sawdust, перлита, waters and foam creator with average density $1150-1250 \mathrm{~kg} / \mathrm{m} 3$ and durability at compression 5 - 8,5 $\mathrm{MPa}$.

2. The technology of application porous monolithic concrete as constructive - warm keeping a material for multilayered designs of external walls and in designs of overlappings in little floors housing construction is developed.

3. The technology of application of elements of a fixed timbering is offered on the basis of the unified obverse and ordinary products from effective concrete by 
thickness of $40 \mathrm{~mm}$ and width of the various length $300 \mathrm{~mm}$, allowing to lower transport and an overhead charge at construction.

4. Rational scopes porous concrete in little floors housing construction are revealed in view of his bearing and protecting functions, durability and warm protecting properties.

5. Technical and economic efficiency of application of designs from porous mixes and the aerated concrete, consisting in deprecication of building materials and budget cost of construction, and also in increase of heat-shielding properties of external protecting designs is proved.

The practical importance of work consists in use of substantive provisions in practice in the construction organizations and in educational process of higher educational institutions of Saint Petersburg. Results of research are finished with an opportunity of their practical realization.

On the basis of results of research the production schedules on erection малоэтажных at home from collect-monolithic designs with a fixed timbering are developed.

The offered recommendations are introduced on objects of new housing construction into Open Company 'MasterBuildCompany' in Saint Petersburg per 1998-2003 (Pushkin, Pavlovsk) where have been erected малоэтажные town-planning complexes from a brick with internal filling porous concrete. Thus, the economy of budget cost of construction on 10 - $15 \%$ has been received in comparison with known comparable designs. The technology of works with porous concrete differs simplicity of performance of operations and the economical charge of building materials. Cost of manufacturing and stacking of concrete makes $350-400 \mathrm{rub} / \mathrm{m} 3$, that in 1,5 - 2 times are more economic than use of blocks gas concrete factory manufacturing in item. Sertlovo.

Results of research are introduced in educational processes SpbGASU on faculty of technology of building manufacture and VITU on faculty of building materials in 1997 2003.

Porous constructive concrete time the structures, made by a method of aeration, is tested and certificated in the center 'Acceptance' (the Certificate of accreditation of test laboratory № GOST P RU. 9001.6.1.0029 Gosstandart of Russia, Minstroy Russia, № 00261 from $7 / 19 / 1996$ of).

Results of four-year-old supervision over a condition of the constructed buildings show, that bearing designs keep the explutation qualities, thus confirming scientific validity and reliability of the developed decisions.

The publication of results and approbation. The basic scientific results of work are published in 20 printed works.

Substantive provisions have been discussed and submitted at scientific and technical conference « Technology and economy of construction. Problems and ways of their decision " in the Siberian state academy of means of communication of Ministry of Railways of the Russian Federation (Novosibirsk, 1997г.), at 54-th Scientific and technical conference young scientific (post-graduate students, candidates for doctorate) and students "Actual problems of modern construction » at St.-Petersburg state 
architectural-building university Minobrazovanija of the Russian Federation (Saint Petersburg, 2000г.), at the international scientific-practical conference « Town-planning problems at the present stage $»$ at Military non-production university MO of the Russian Federation (Saint Petersburg, 2000).

For an estimation of efficiency as basic two variants of traditional technology of erection of external brick walls for little floors apartment houses (tab. 1.) are accepted.

Table 1 System of technical and economic parameters of variants of technology Manufactures of works for the device of external walls of apartment houses

\begin{tabular}{|c|c|c|c|}
\hline \multicolumn{4}{|c|}{$\begin{array}{l}\text { System of Technical and economic Variants } \\
\text { parameters }\end{array}$} \\
\hline (2) & $\begin{array}{l}\text { № } 1 \\
\text { continuous } \\
\text { brick wall } \\
\end{array}$ & $\begin{array}{l}\text { № } 2 \text { layered brick } \\
\text { wall with gas } \\
\text { concrete blocks }\end{array}$ & $\begin{array}{l}\text { № } 3 \text { brick wall with } \\
\text { aerated concrete }\end{array}$ \\
\hline Thickness of a wall, sm & 77 & 58 & 81 \\
\hline Durability, MPa & 10 & 2 & 5 \\
\hline Heat conductivity, $\mathrm{W} / \mathrm{m}^{\circ} \mathrm{K}$ & 0,26 & 0,10 & 0,25 \\
\hline Volumetric density, $\mathrm{kg} / \mathrm{m} 3$ & 1100 & 400 & 1150 \\
\hline Cost of $1 \mathrm{~m} 3, \mathrm{rub}$ & 1500 & 820 & 350 \\
\hline Frost resistance, cycles & 25 & 25 & 25 \\
\hline USE charges, rub & \multicolumn{3}{|c|}{ Are accepted identical } \\
\hline The sizes, mm & $\begin{array}{l}250 \times 120 \times 6 \\
5\end{array}$ & $600 \times 300 \times 250$ & Monolithic variant \\
\hline Fire resistance & \multicolumn{3}{|c|}{$\begin{array}{l}\text { Group of nonflammable building materials in accordance } \\
\text { with GOST } 30244\end{array}$} \\
\hline Cost of $1 \mathrm{~m} 2$, rub & 1171 & 622 & 562 \\
\hline $\begin{array}{l}\text { Use of waste products of } \\
\text { manufacture }\end{array}$ & No & No & Is \\
\hline
\end{tabular}

Variant №1 - a continuous brick wall from the effective hollow ceramic brick made according to GOST 530-95 NPO 'Ceramics' of Saint Petersburg.

Variant №2 - a layered brick wall with gasconcrete the blocks made 211 KGBI in items. Sertlovo of Saint Petersburg and a brick by a variant №1. 
The initial data of variants are resulted in tab. 1. and on fig. 1.

a)

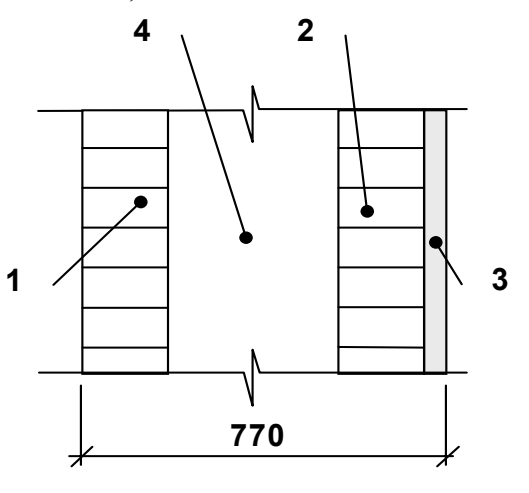

б)

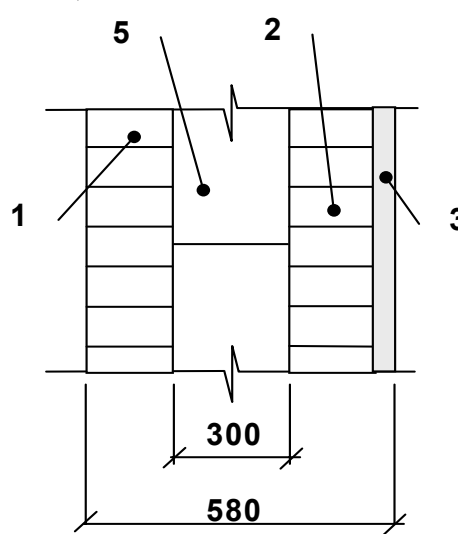

B)

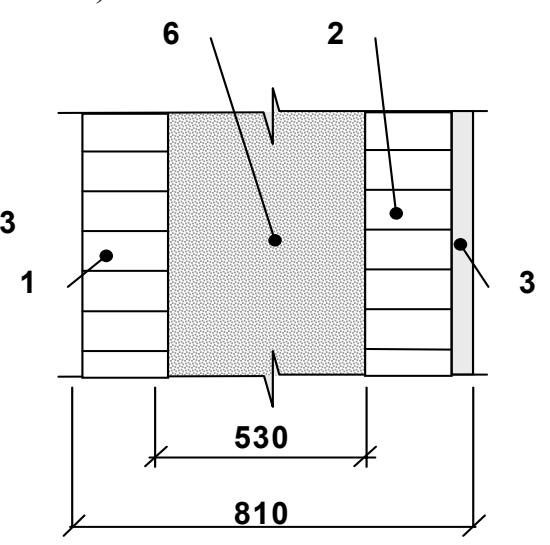

Fig. 1. Compared variants of technologies of the device of brick external walls for little floors apartment houses in conditions of Saint Petersburg: and - a continuous bricklaying (a variant № 1); , in - multilayered bricklayings (variants № 2 and № 3);

1 - an external number of a brick; 2 - an internal number of a brick; 3 - plaster; 4 - an average layer of a brick; 5 - gas concrete blocks; 6 - porous-sawdust-sandy monolithic concrete.

Thus, developed (a variant №3) technology ТПБ in 2,1 times is more economic than existing technology of a continuous brick wall and in 1,11 times - technology with gas concrete blocks. The received data are evidently reflected on fig. 2 . On their basis dependences of cost of walls and the charge of materials on their area (fig. 3, 4) are constructed.

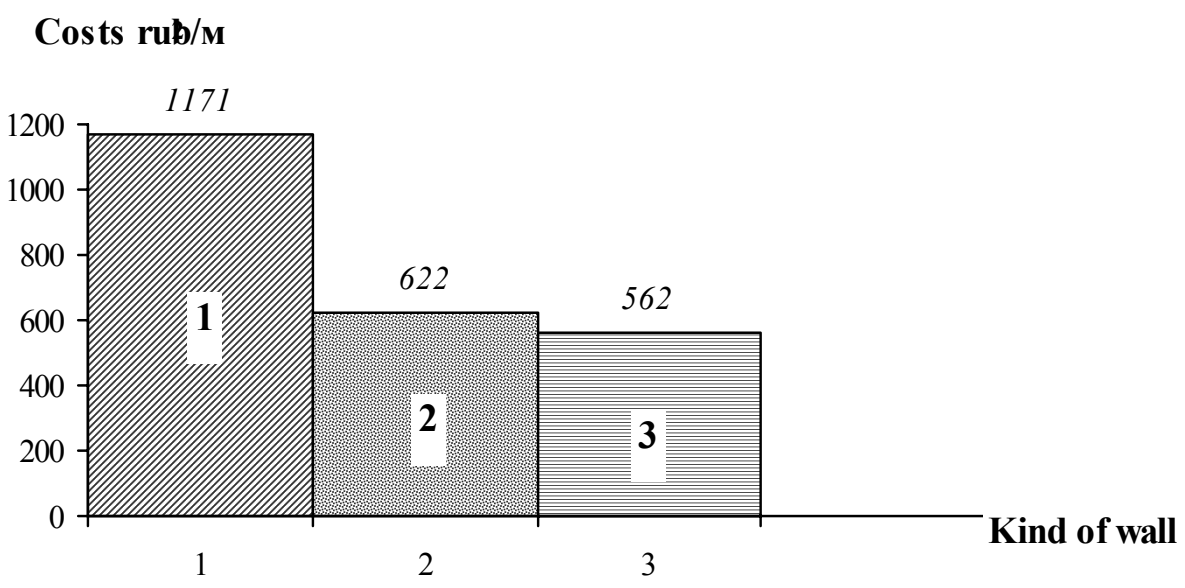

Fig. 2. Comparative values of cost of an external wall of $1 \mathrm{~m} 2$

Various constructive decisions:

1 - a layered brick wall from porous brick NPO 'Ceramics' (a variant № 1);

2 - a layered brick wall with gas concrete blocks 211 KGBI (a variant № 2);

3 - a layered brick wall with source monolithic sawdust-sandy concrete (a variant № 3). 


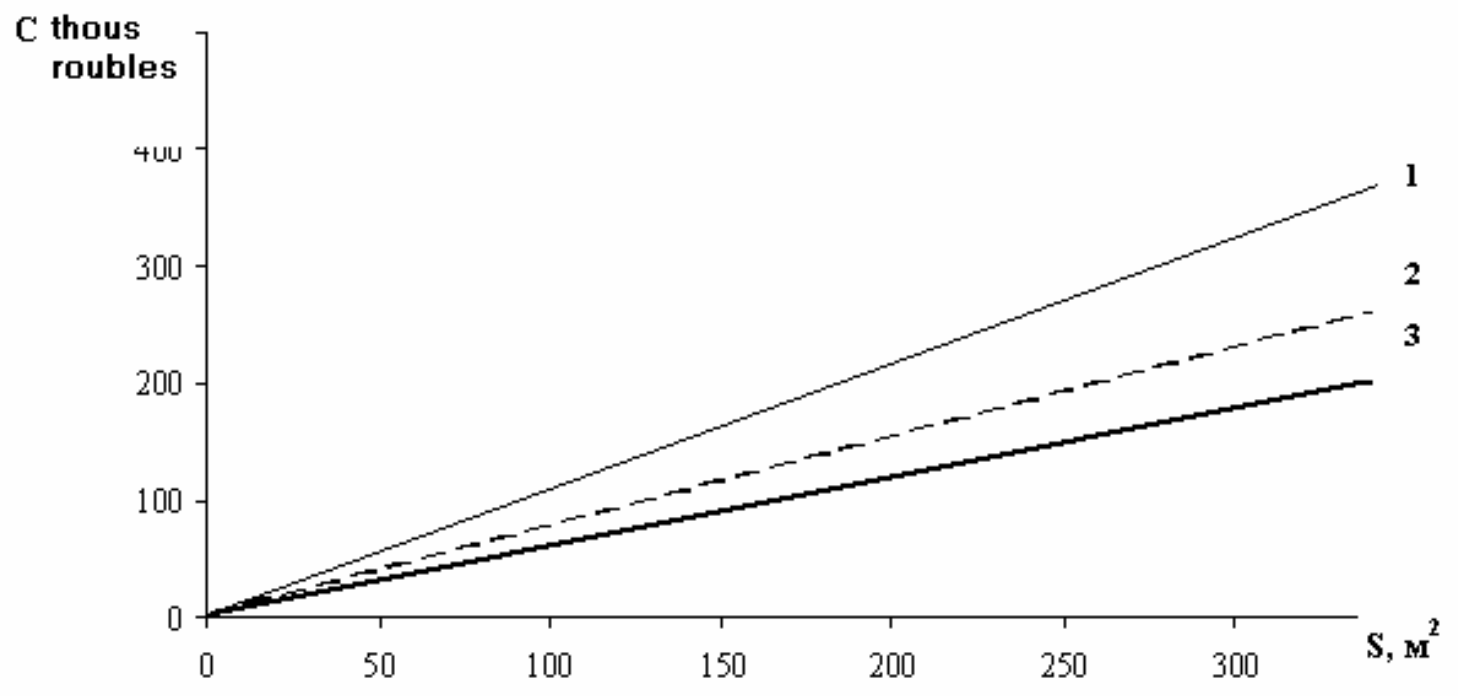

Fig. 3. Dependences of cost of external walls of various designs of apartment houses on their area: 1 - a layered brick wall from source brick HПО 'Ceramics' (a variant № 1);

2 - a layered brick wall with gas concrete blocks 211 КЖБИ (a variant № 2);

3 - a layered brick wall with source monolithic sawdust-sandy concrete (a variant № 3).

From the analysis of cost of the external walls reflected on fig. 2, follows, that the specific economy on $1 \mathrm{~m} 2$ of a wall by 3 variant makes 60 roubles and 609 roubles in comparison with 2 and 1 variant.

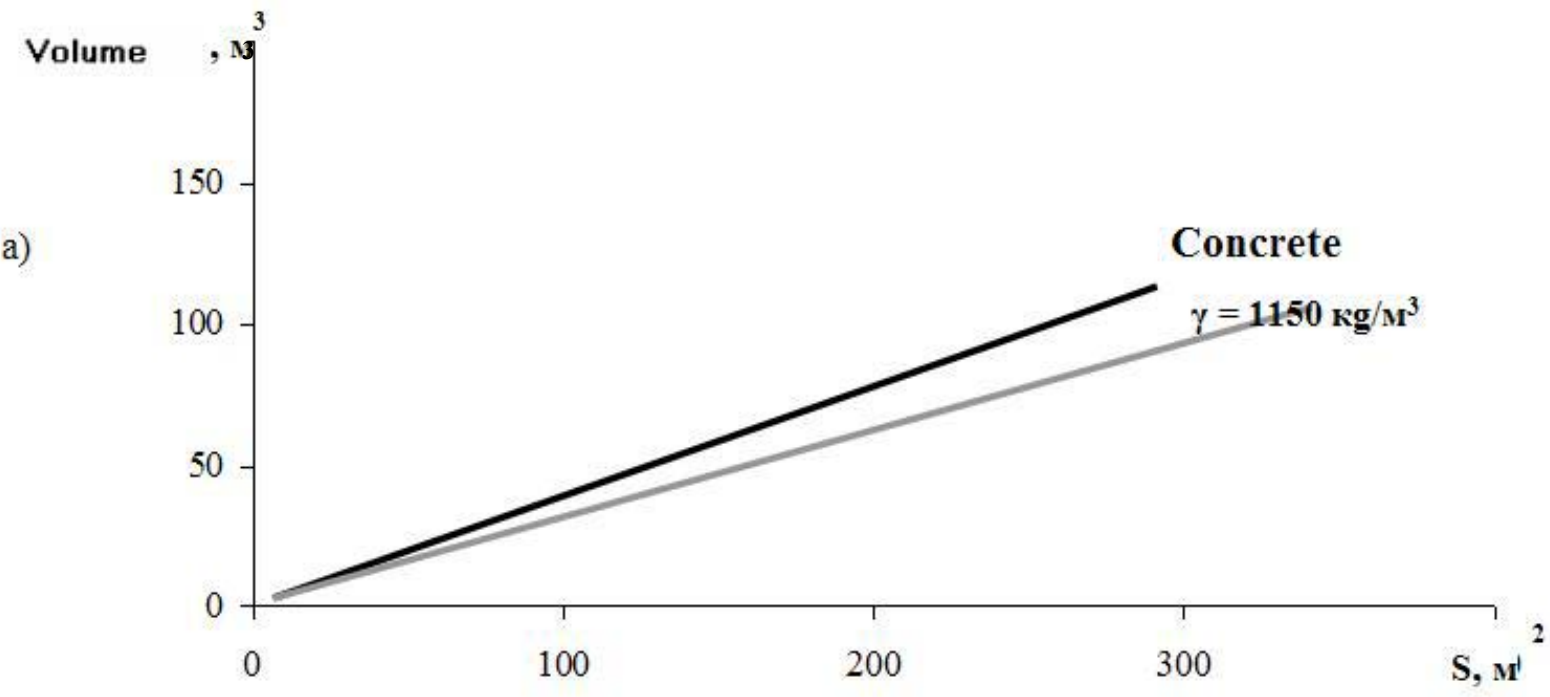




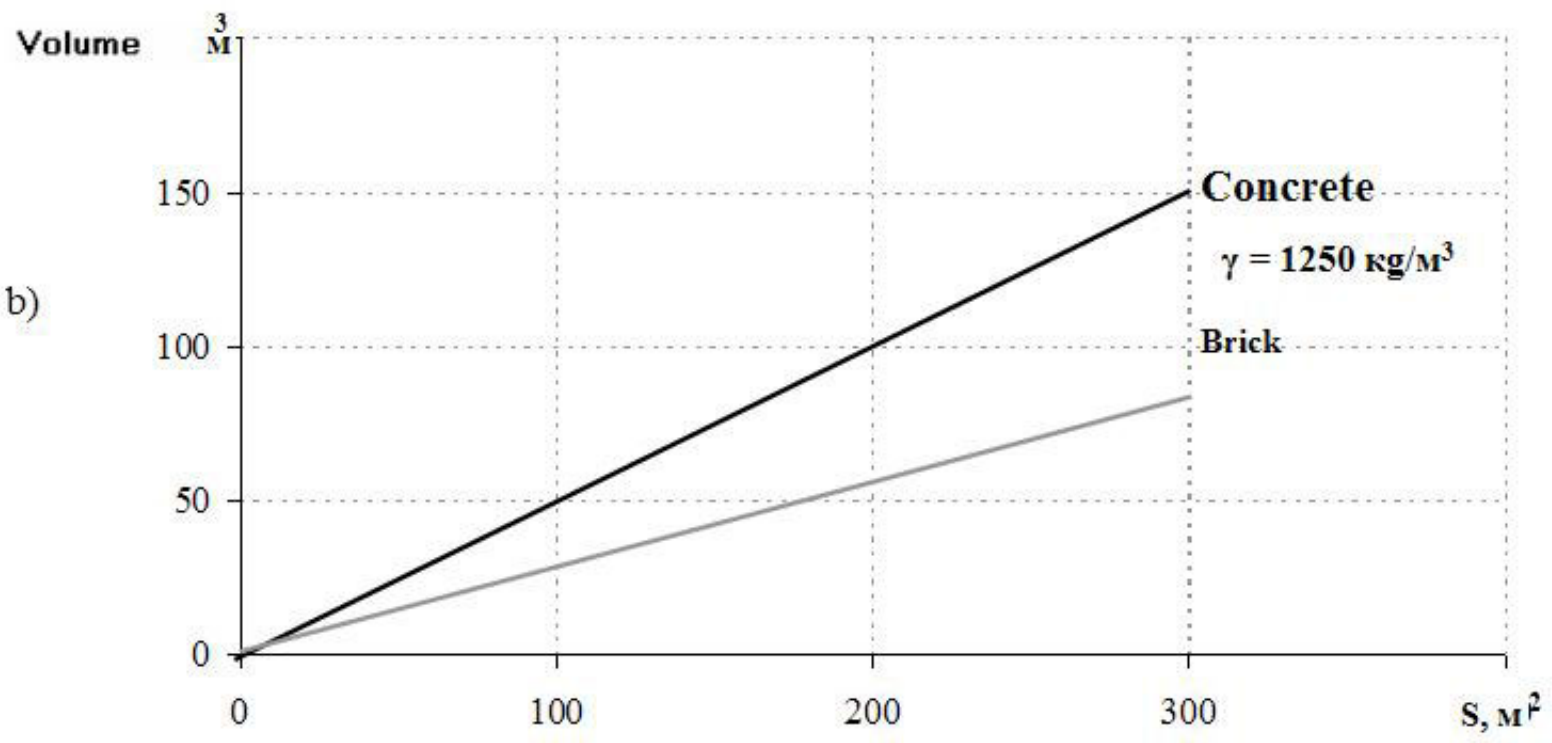

Fig. 4. Dependence of the charge of concrete and a brick in multilayered external walls with use of technology porous sawdust-sandy concrete from the area of walls:

$$
\begin{aligned}
& \text { a - concrete with } \gamma=1150 \mathrm{~kg} / \mathrm{m} 3 ; \\
& \mathrm{b} \text { - concrete with } \gamma=1250 \mathrm{~kg} / \mathrm{m} 3
\end{aligned}
$$

Thus, it is logical to draw the following conclusions.

1. The technology of application energy care building systems in little floors townplanning systems with use of designs from porous sawdust-and perli concrete is developed. The technique of a technical and economic estimation of efficiency of the offered technology at all stages of a production cycle is proved: factory manufacturing, transportation, performance of civil and erection works, operation of the erected designs.

2. The analysis of variants of use of designs from aerated concrete has shown their high technical and economic efficiency in comparison with comparable modern analogues. In comparison with technology of a continuous brick wall from porous a ceramic brick in density of $1100 \mathrm{~kg} / \mathrm{m}^{3}$ heat conductivity 0,26 ВT/M 0K manufactures HПO 'Ceramics' (of Saint Petersburg) the effect makes 609 roubles on $1 \mathrm{~m} 2$ of a surface of an external wall. Expenses for a bricklaying make 1171 roubles $/ \mathrm{m}^{2}$, and on a concrete laying - 562 roubles $/ \mathrm{m}^{2}$, i.e. in 2,1 times it is less. In comparison with technology of a bricklaying with use газобетонных blocks in density of $400 \mathrm{~kg} /$ $\mathrm{m} 3$ heat conductivity $0,10 \mathrm{BT} / \mathrm{M} 0 \mathrm{~K}$ manufactures $211 \mathrm{KGBI}$ (item. Sertlovo) the effect makes 60 roubles $/ \mathrm{m}^{2}$. Expenses on газобетонную a laying are made with 622 roubles $/ \mathrm{m}^{2}$, that in 1,11 times is higher than the developed monolithic technology.

3. Research has shown high efficiency and perspectivity of expanded use of the offered technology porous concrete for the construction organizations in Saint Petersburg at erection little floors apartment houses. Rather - economic efficiency of technology at use of one mixing installation at service by one working reaches 1,734 million roubles a year, and two installations with two working - 4,624 million roubles a year.

4. Introduction of the developed technology porous concrete and check of efficiency of technological decisions in conditions of building sites of Saint Petersburg is executed at erection little floors apartment houses. The technology is used by Open Company « the Master Build the Company » at construction of two and three-tier apartment houses in. Pushkin and. Pavlovsk in 1999 - 2003. Experience of use of technology has shown sufficient convergence of theoretical settlement parameters of efficiency with practical estimations on the facts of construction and operation. Thus the technology of works with porous concrete differs the economic charge of 
accessible building materials and simplicity of performance. The technology allows a message of work at negative temperature (up to-15 0C) with use against frost additives and a covering бетонируемых surfaces warm keeping matches.

5. The technology of use porous the concrete, based on preparation of a mix in specially developed optimum concrete mixes is offered to installation and stacking of a mix between an internal and external layer of a multilayered bricklaying in external walls of apartment houses. Offered technological and constructive decisions allow to use optimum constructional (bearing) and heat-shielding (protecting) properties porous concrete on the average a layer of a wall, to reduce quantity of seams and joints and to organize technological process on a building site. It provides achievement of an object in view, depreciation of construction and increase of heat-shielding properties of external protecting designs.

6. Research of adaptability to manufacture of application of designs from porous concrete with the help of methods expert estimating has shown a high level of adaptability to manufacture of the developed decisions in view of factory, transport, assembly, operational adaptability to manufacture and adaptability to manufacture of modernization and reconstruction. Thus the integrated criterion of adaptability to manufacture is equal 0,665 , that promotes increase of general efficiency of process of erection little floors town-planning complexes.

Ph. 8-812-316-43-13

Fax: 8 - 812 - 316 - 15 - 25; rector@spice.spb.su , 198005 , Russia, Saint-Petersburg, 2-nd Krasnoarmeiskaja str 4 , of 213 St Petersburg State Architectural and Civil Engineering University .

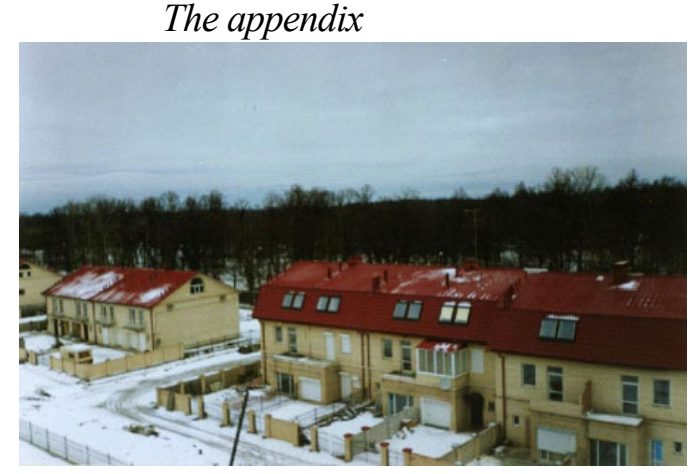

a) A panorama of houses from the party

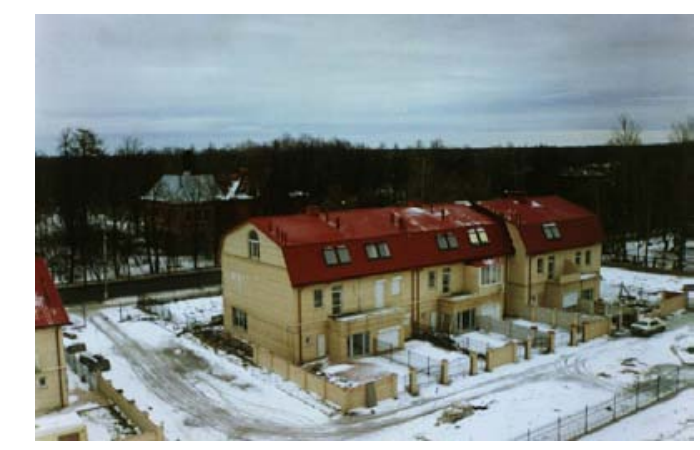

6-room

energy effect the house

Complex of 2 floor buildings

Domestic facades;

Photo 1. A town-planning complex of a housing estate two-storeyed houses with the penthouses erected in $\mathrm{SPb}$ in 1999. Pushkin, Pavlovsk highway, д. 61, 63, 65. 


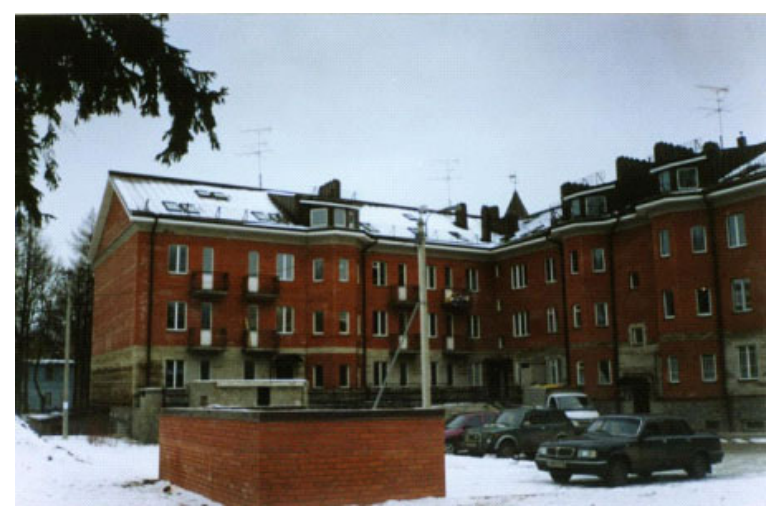

A) A domestic facade

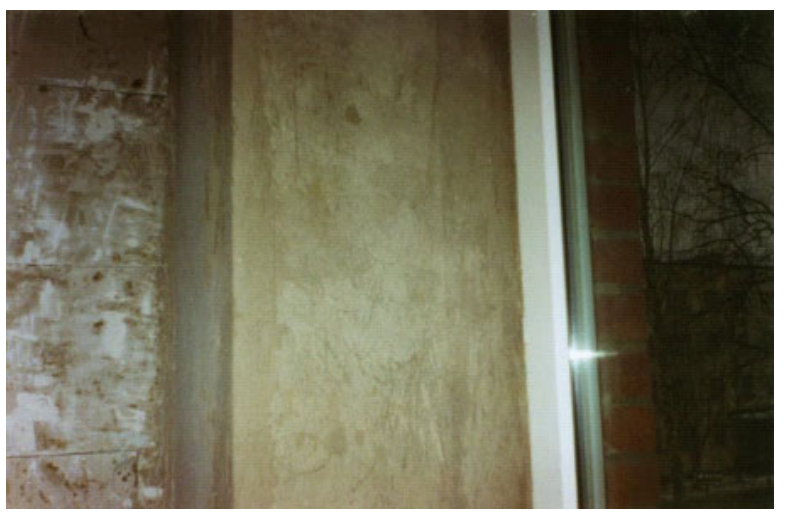

б) A multilayered external wall with an internal layer from porous monolithic concrete

Photo 2. Little floors a town-planning complex of 3 floor apartment houses with penthouses in Saint Petersburg. Pavlovsk, street. Vasenco, h. 5. Year of construction - 2001.

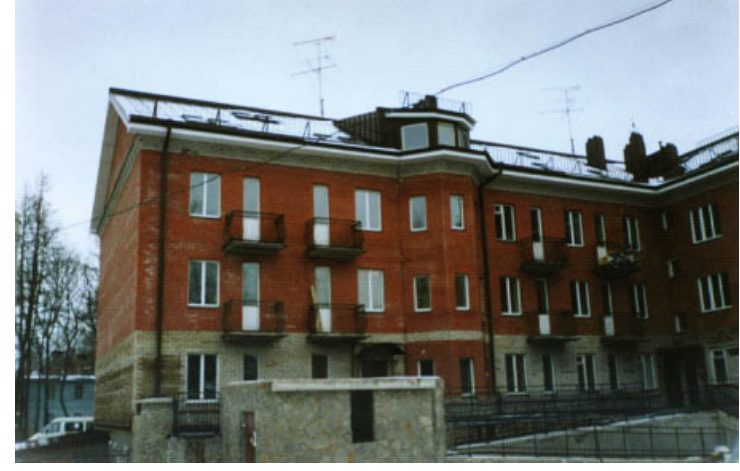

A) Absence of operational remarks for 2 years

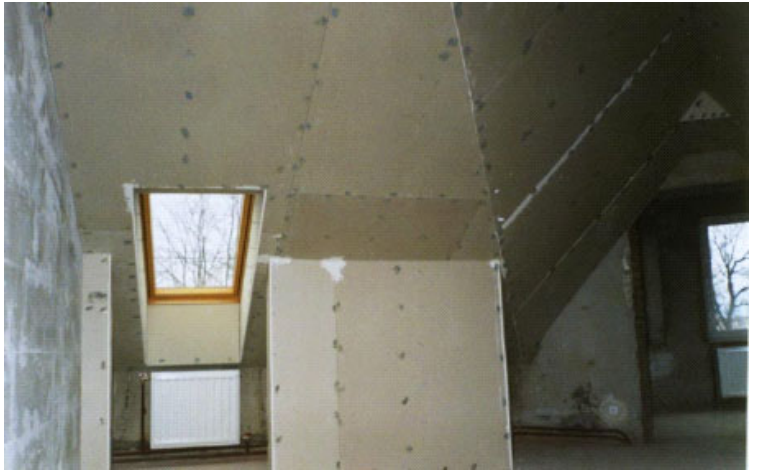

б) porous monolithic concrete in external walls and overlappings in a mansard floor

Photo 3. little floors a town-planning complex from 3 floor apartment houses with penthouses in Saint Petersburg. Павловске, street. Vasenco, h.5. Year of construction - 2001: 


\title{
Building Materials in Arctic Climate
}

Ole Mejlhede Jensen, Professor, Department of Civil Engineering, Technical University of Denmark,omj@byg.dtu.dk

\begin{abstract}
Building in the artic requires special attention on the appropriateness of building materials. The harsh climate makes execution difficult and sets unusual requirements for the pure material properties. In addition, there is a lack of choice of good, natural building materials in the arctic. This results in high transport costs. The building materials situation in Greenland may potentially be improved by intensifying the reuse of building materials or by promoting the local production of building materials.
\end{abstract}

\section{COLLAPSE OF A CONCRETE BUILDING}

Figure 1 shows the appearance of a building constructed during the winter 1962-63 in Lahti, Finland (Nykänen (1964)). The building has a height of $30 \mathrm{~m}$ and includes a basement and a bomb shelter - for extra safety. Windows, doors and heating system was installed, and to finish the interior of the building, heating was put on. The next day, the building collapsed. Fortunately nobody was injured.

The bearing structure was made of concrete. It was in-situ cast in a period with constant low temperatures around $-10^{\circ} \mathrm{C}$. Subsequent investigations showed that the concrete had been exposed to premature freezing: In reality the erected building consisted of 9 stories of reinforced ice, which melted when the heating was put on. Building in the artic requires special attention on the performance of building materials.
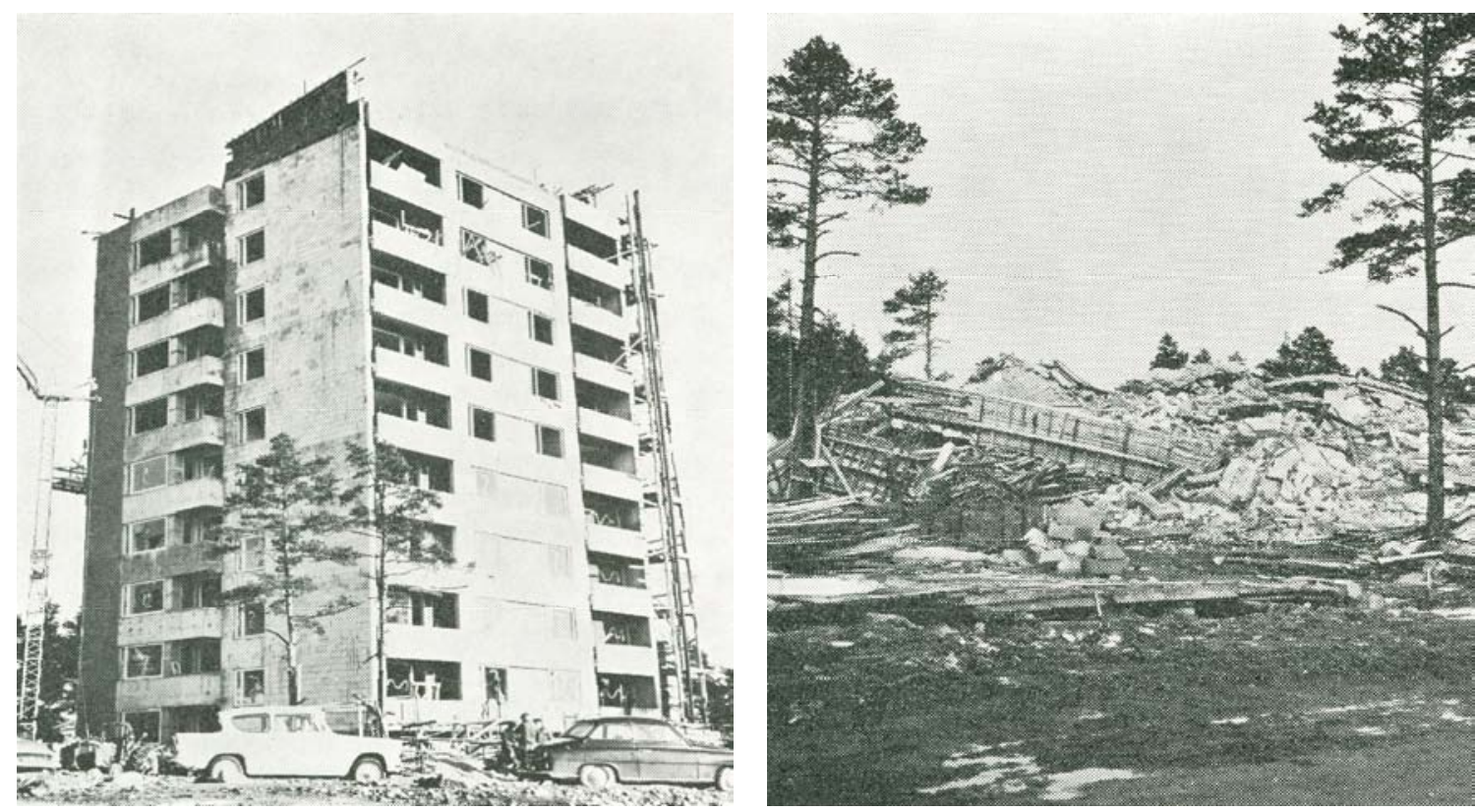

Figure 1 The collapse of a 9-story building due to premature freezing of the loadcarrying concrete (Nykänen (1964)). This type of difficulties are easily prevented with simple precautions during the casting and early hardening. 


\section{THE ARCTIC REGION}

The arctic region is not naturally defined, since it is neither a continent nor a sea, see figure 2 . The polar circle can be considered an astronomic boundary for the arctic region. The polar circle separates the part of the earth where the midnight sun can be experienced: the $66^{\text {th }}$ northern latitude. From a human point of view, the midnight sun is a characteristic feature, however, with regard to building technology it is not relevant.

The usual geographic definition of the arctic region is based on the $10^{\circ} \mathrm{C}$ July isotherm - it is a climatic definition. As seen from figure 2 this deviates significantly from the polar circle due to the land masses and circulation of sea water. The climate is the basis for a building technology definition of the artic region, however, the $10^{\circ} \mathrm{C}$ July isotherm is not the most relevant. An element that has to be paid great attention to in cold region structural engineering is permafrost. Permafrost is related to the mean annual temperature. Buildings and infrastructure may experience severe settlement because of thawing during spring or due to the heat from buildings. The presence of permafrost may serve as a geotechnical definition of the arctic region.

For building materials both the availability and the appropriateness is relevant. For the arctic region, availability has been very important in a historical perspective. With regard to this, the so-called tree line appears to be the fundamental building materials definition of the arctic region. The tree line is the limit for arboreal growth. Except a small amount of driftwood from the Siberian or Canadian spring flood, wood is not naturally available north of the tree line. Since wood historically is the only significant source of heat this also precluded the production of bricks and cementing materials in the arctic region.

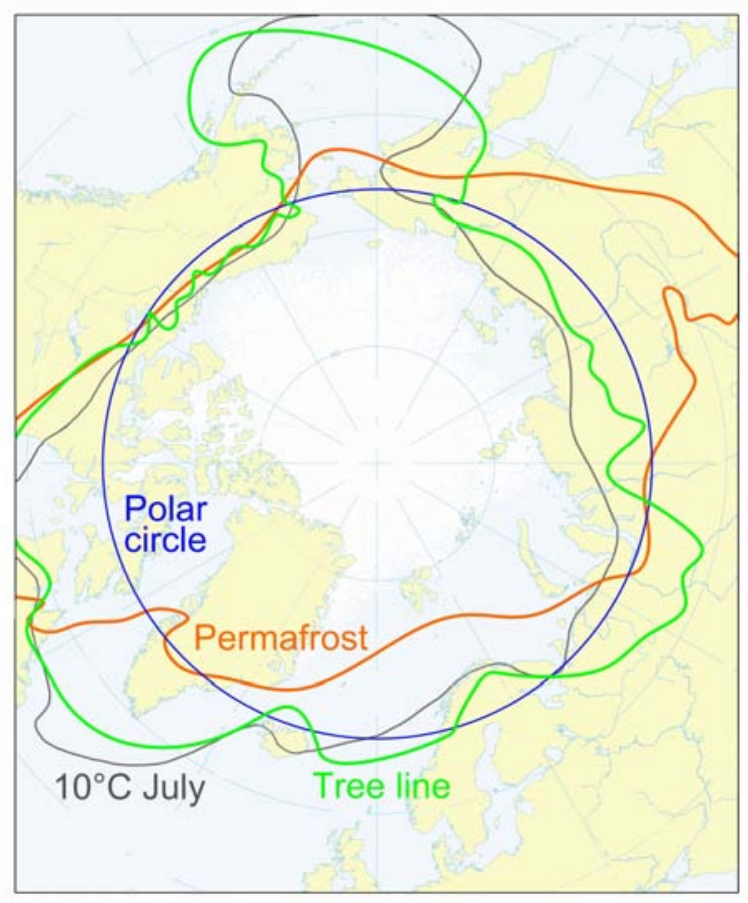

Figure 2 The arctic region is not straight-forward to define. From a narrow building materials point of view the tree line may be considered a natural boundary. Partly based on Crittenden (1988). 


\section{THE ARCTIC CLIMATE}

The climate conditions in the arctic are extreme: In some areas temperatures may reach $-70^{\circ} \mathrm{C}$ and for example in Verkhoyansk in Russia temperature differences of more than $100^{\circ} \mathrm{C}$ can be experienced between summer and winter. High winds are another characteristic feature. Especially at the arctic coast of Greenland wind speeds of up to $320 \mathrm{~km} / \mathrm{h}$ are observed. The effect of these so-called katabatic winds is worse than a typhoon due to the high density of air at low temperatures (Eranti and Lee (1986), Strub (1996), Cappelen et al. (2001)). In addition, the wind will often carry snow crystals. This exposes the buildings to a sand-blasting effect. The traditional arctic house (including the igloo) reflects the climate. It is a small, compact, dome-shaped structure to minimize the heat loss and to make the strong winds to blow over, not against.

\section{APPROPRIATENESS OF BUILDING MATERIALS IN THE ARCTIC REGION}

The lack of choice of good, natural building materials forced the Eskimos to build their homes from very unusual or basic materials. Examples of this are the snow house, the tent made of seal skin and whalebones, and the more luxurious winter residence of rough field stone and sod (Enel (1996)). Today, local building materials are not much used, so issues relating to the transport of the materials are very relevant for the selection. When evaluating the appropriateness of building materials in the arctic region attention should be paid to transport, execution and the pure material properties.

Wood is the classical arctic building material. It is light compared to its weight, it is a reasonable insulator and wood construction can be done independent of the temperature. In addition, the biological degradation of wood is minimized at low temperatures.

Concrete is also well suited for the arctic region, if the execution phase is paid attention. As described previously concrete has to harden to a certain extent before it is exposed to the first freezing. If not the strength development may be completely destroyed. However, by insulating the formwork concrete casting can be done at very low temperatures. Another point of observation is temperature differences that may develop in the concrete during the first weeks of hardening, and during form stripping temperature differences in the concrete need to be under careful control to avoid cracking of the concrete. Chemical degradation of concrete, such as rusting of the reinforcement is significantly reduced due to the low temperatures. The chemical reaction rate is typically halved for every $10^{\circ} \mathrm{C}$ the temperature is lowered, cf. the so-called Arrhenius' equation.

Brick and mortar have material properties well suited for the arctic climate. However, transport of materials and execution are very problematic. Both the construction and the subsequent hardening phase realistically need environmental temperatures above approx. $5^{\circ} \mathrm{C}$. Furthermore, in facades etc. the brickwork does not contribute to insulation of the building.

Metals may present difficulties in a cold environment. On their South Pole expedition Robert Scott and his men froze to death because the tin seams in their kerosene cans leaked due to brittleness in extremely cold temperatures. Fridtjof Nansen on his arctic expeditions noted that the sledge runners of steel broke like glass (Suenson (1911)). At normal temperatures steel is a ductile material, however, depending on the composition its fracture toughness may be severely reduced at low temperature. Welds are a particular source of brittle failure, and field-welding of proper quality is more difficult at low temperatures. 
Plastics may like metals show a strong temperature dependency of its mechanical properties. Some plastics have a so-called glass transition temperature below which they exhibit brittle behaviour; at higher temperatures such plastics are soft and ductile. In addition, plastics have a coefficient of thermal expansion which is up to 10 times higher than for metal, concrete and wood. This limits their use in combination with other materials especially in arctic climate. In this connection it should be noted that paints in general are plastics - alkyd and acrylic paints.

\section{POTENTIAL FOR DEVELOPMENT - WITH FOCUS ON GREENLAND}

During the 1980ies severe degradation of concrete structures from the early 1970ies was observed in the Arabian Peninsula (Walker (2003)). A reason for this was that British standards were used in this region during the extensive construction work of this period standards which were developed for the British climate, not the Middle East. Similarly it should be considered if the building materials and construction techniques used in Greenland are optimal for Greenland.

The execution phase is generally problematic in Greenland. Perhaps it could be an advantage to have major structural elements assembled on factories, and shipped to Greenland, rather than shippling the separate materials. In Denmark construction costs can be cut by $30 \%$ based on this concept. For Greenland savings may be even more.

Another potential route of development is to consider local production of building materials at Greenland. This can potentially minimize transport costs and improve the employment situation. It is the irony of faith that insulation materials are particularly expensive in Greenland (Kreiner and Gaarslev (1980)). Production of expanded polystyrene insulation boards is simple technology. It could be done at a production site in Greenland - for example at a small ship. In that case only the non-expanded product would need to be shipped to

Greenland, with a volume 50 times less than the expanded product. Or this idea could be brought even further: Perhaps it is profitable to produce building materials from local raw materials at Greenland. An example of this, which is under investigation, is production of expanded clay aggregates (Villumsen (2005)).

Reuse of building materials is a hot topic all over the world and might be particularly relevant considering at Greenland, where transport costs are high. Potentially, reprocessing of the building materials could be done on mobile facilities, e.g. special ships.

\section{REFERENCES}

Nykänen, A. 1964. Collapse of a new-erected building (in Swedish: Raset av en nybyggnad), Nordisk Betong, Vol. 8, no. 4, pp. 427-456.

Crittenden, E.B. 1988. Cold dry climate construction, Encyclopedia of architecture: Design, engineering \& Construction. pp. 642-659.

Eranti, E.M. and G.C. Lee. 1986. Cold region structural engineering. McGraw-Hill, New York.

Strub, H. 1996. Bare Poles - Building design for high latitudes. Carleton University Press, Ottawa.

Cappelen, J. et al. 2001. The observed Climate of Greenland, 1958-99. Technical Report 0018, Danish Meteorological Institute, Copenhagen. 
Enel, C. 1993. Elisa Maqe fortoeller om det traditionelle hus og det traditionelle telt. Ammassalik Museum, Ammassalik.

Suenson, E. 1911. Construction materials (in Danish: Byggematerialer). P.E. Blume, Copenhagen. §225, p. 99.

Walker, M. 2003. An overview of work on reinforced concrete in hot and aggressive environments, 7th International Conference on Concrete in Hot \& Aggressive Environments, 13-15 October 2003, Bahrain.

Kreiner, K. and A. Gaarslev. 1980. Byggeri i Grønland. Nyt fra Samfundsvidenskaberne, Copenhagen.

Villumsen, A. 2005. Personal communication. 


\title{
New Building Code
}

Janus Køster, Civil engineer, Department of Housing and Infrastructure, Greenland Home Rule,jks@gh.gl

\begin{abstract}
Through the last 3-4 years the Department of Housing and Infrastructure have been preparing a new Building Code. This presentation has especially focus on the new regulations for the thermal insulation of buildings. The requirements for the insulation standard in new building have been modified, so that the heating need is reduced to around $75 \%$ compared to the existing standard.
\end{abstract}

The plan is to release the new Building Code in 2005, but there might be a transition period before implementation of the new requirements for thermal insulation.

\section{BACKGROUND}

Sector programme for renovation with an environmental and energy saving effect 20002003

July 2nd 1999 an agreement between the Danish government and the Greenland Government was made concerning the carry out of a sector programme concerning an extraordinary renovation of the housing stock. The deal implies that the Danish State through the arctic part of the MIFRESTA framework (Environment, Peace and Stability framework) contributed with 50 million DKK a year to the sector programme in each of the years 2000-2003. In the same period the Greenland Home Rule obliged it self to spend 275 million DKK a year to the carry out of the project.

The objective for the sector programme was that the focus from the extraordinary renovation effort should be directed on environmental- and energy-situation in order to benefit not just the neighbourhood, but also the arctic and global environment. The effort was directed to more areas, e.g. 'General conditions' under which the updating of the Building Code is to be found.

\section{Terms of Reference}

A committee has been appointed to prepare the revision of the Building Code.Members of the committee are representatives from the Greenlandic Municipals National Association (KANUKOKA), the Association of Technical Consultants (TSP) and the Department of Housing and Infrastructure (IAP).

In the policy guidance given to the committee it is among others stated that there according to 'Sector programme for Renovation with an Environmental and Energy improving effect' must be established requirements, which promotes energy savings within buildings.

A proposal to a new Building Code was ready in January 2002. The proposal was then sent to hearing with relevant parts. The goal to have the new Building Code in Danish and Greenlandic to be implemented some time during 2002 was not achieved. Instead it is expected that a new Building Code can be implemented with a suitable transition period during 2005. 


\section{PROPOSAL TO A NEW BUILDING CODE}

\section{Structure and Content}

The structure of the Code is a lot like the Danish Building Code (BR95), while the content is suited the society and climate conditions in Greenland. The Danish system has one Code for all buildings except small houses and another Code for small houses only, where as in Greenland there is only one Code valid for all buildings. The Code is furthermore built up with an instruction text in a separate column to the right of the text itself. A Greenlandic version is being produced.

In the following you will find a short overview of each of the essential changes compared to the Building Code from 1982 (GBR82):

Chapter 1. Administrative provisions. Provisions concerning fees for a building permit have been written in the Code. It is recommended that each municipal council - within the administrative law principles - themselves decide the calculation rules.

Another new thing is the possibility for dialog beforehand. Before a building permit is given it is possible for the municipal council in dialog with the building owner to straighten out the frames for the building project, e.g. time schedules and necessary documentation the building owner must deliver. This is done in order to create flexibility in the handling of building-cases e.g. building projects made within total-enterprise, where the planning in detail typically is done while the project is on-going.

Also new are provisions concerning temporally disposal over neighbourhood areas, when this e.g. is necessary for the carry out of a building, reparation or maintenance job.

Chapter 2. Utilisation of the site. This chapter has been given new contents. It is stated that the municipal council in each case must estimate the whole project and its effects on the surroundings in concern to area size, distances, height and floor numbers, light conditions, floor area and the area without building. In other words this chapter now contains a duty to look at a number of building-regulation conditions in each building project, which usually is put down in the local planning.

Chapter 3. Height and distances. This chapter has also been given new contents. The requirements for fire-distances between buildings have been moved to chapter 6 . Fire Safety. This chapter contains rules for calculating floor area, height conditions from levels and distances.

Chapter 4. Arrangements of Buildings. The regulations in this chapter have among others been created against a background from the parliament regulation on help to persons with an extensive handicap. According to the regulation, which have been into force since 1995, all public buildings and facilities must as far as possible be arranged in a way which allows all people to access and use it. This is the first attempt to outline rules in order to meet the handicap-regulations. There are still certain considerations on the final shaping of some of the handicap regulations.

The requirement for ceiling height is raised from $2.3 \mathrm{~m}$ till $2.5 \mathrm{~m}$ in apartment houses and from $2.1 \mathrm{~m}$ till $2.3 \mathrm{~m}$ in one-family houses and terraced houses. For buildings in settlements there is still an exception rule, which allows certain arrangements to be different, as long as 
the municipal council sees it as suitable. Finally there have been added rules for arrangements of other buildings than dwellings - especially workspaces.

Chapter 5. Design and Construction. New here are extended safety regulations for glass constructions. Furthermore there have been enrolled regulations for playground equipment.

Chapter 6. Fire Safety. The rules of fire distances are now to be found in the chapter concerning fire safety. The rules have been formulated in a more general way: there are now rules about a minimum distance between a building and boundaries to an area where there will be built on. The final minimum distance between two buildings is still the same as according to GBR82 (fire distance equals the sum of the two building's boundary distances).

Furthermore the chapter has been expanded to more applicable categories (day-care centres, offices etc.), which was a wish from many sides.

Chapter 7. Damp proofing. The rules have been given as function demands, which in principal gives more scope to meet the requirements. The instruction text is rather comprehensive and stays close to the rules from GBR 82. In other words are the absolute demands from 1982-Code to be seen as recommended ways to meet the function demands.

Chapter 8. Thermal Insulation. The requirements for the insulation standard in new building have been modified, so that the heating need is reduced to around $75 \%$ compared to the existing standard.

The chapter gives three ways to meet the requirements of thermal insulation:

- either by observance of some demand on the U-values for each building element and at the same time limit the area of windows and outer doors till a maximum of $22 \%$ of the floor area,

- or by staying within the maximum permissible heat loss (heat loss frame) for the house with different U-values and area of windows and outer doors (the maximum demand for the U-values must still be meet),

- or by staying within the maximum thermal energy required for heating and ventilation (energy frame) per year (the maximum demand for the U-values must still be meet).

Any of these three methods may be used.

Furthermore the linear thermal transmission, in short linear loss $\Psi$, is new. By $\Psi$ is meant the heat loss through a thermal bridge.

Chapter 9. Acoustics. The chapter contains demands on airborne sound insulation and impact sound pressure for dwellings, hotels, care-institutions etc. For classrooms there are separate demands for airborne sound insulation, impact sound pressure and sounds absorption. The municipal council can require documentations by measurements.

Chapter 10. Heat Producing Appliances and Chimneys. This chapter contains demands concerning the carry out and installation of heat producing appliances and chimneys. The chapter is simplified and some of the old detailed regulations have been left out.

Chapter 11. Indoor climate. There is distinguished between two ventilation systems:

- systems for natural ventilation and

- systems for mechanical ventilation. 
For apartment houses with more than 4 apartments mechanical ventilation is required. In living rooms in residential homes for children or young people with an area over $250 \mathrm{~m}^{2}$ or which is meant for more than 20 children and in classrooms in schools above $250 \mathrm{~m}^{2}$ or which is meant for more than 20 children must be supplied with mechanical ventilation.

Chapter 12. Services. The rules have been given as function demands, which in principal gives more scope to meet the requirements.

There is a principal demand that the ventilation systems must be made with efficient energy recovery aggregates. It is possible to depart from the demand when the heat cannot be reused on a reasonable way.

Chapter 13. Farm Buildings and similar buildings. For farm buildings in the sheep breading industry there are limited demands to the building constructions.

\section{REQUIREMENTS TO THERMAL INSULATION}

\section{The thermal transmittance $U$ and the linear loss $\Psi$}

The Building Code gives two sets of demands for the U-values and $\Psi$-values for building components separating heated space from the exterior air. One set (standard-values) are valid for building components surrounding rooms, which are normally heated till minimum $18^{\circ} \mathrm{C}$. The other set (maximal-values) are valid for building components surrounding rooms, which are normally heated till minimum $5^{\circ} \mathrm{C}$.

In Table 1 are shown both the new and the old U-values and $\Psi$-values (standard-values) according to the new and old Building Code.

Can it be documented that each of the building components has a U-values/ $\Psi$-value which is less than or equal to the standard-values, the demands for thermal insulation are met. The total area of windows and outer doors (incl. skylights, glazed curtain walls and hatches) towards the open must be below $22 \%$ of floor area of the heated space.

U-values and $\Psi$-values must be calculated in accordance with 'Directions for Calculations of Building's Heat Loss' (Forskrifter for beregning af bygningers varmetab) from the Greenlandic home government and DS 418: Rules for Calculation of heat loss from buildings.

In a wooden house it is normally accepted to neglect linear losses in corner assemblies between walls, assemblies between wall/loft and between wall/floor (insulation is unbroken).

The maximum values of $U$ and $\Psi$ must always be kept, but presupposes furthermore that the heat loss frame or the energy frame is calculated for the whole building, in accordance to the following definitions.

\section{Heat loss frame}

By the heat loss frame is meant the design heat loss due to transmission calculated for a reference building with building components with U-values according to the standard-values. The demands for thermal insulation are seen as kept - even though the U-values and $\Psi$-values are changed and the total window and outer door area is increased - as long as the total heat loss does not exceed the heat loss from the reference building. Each of the building components must anyhow always be insulated according to the maximum-values of $U$ and $\Psi$. 
Table 1: $\quad$ Demands for U-values and $\Psi$-values for building components before and after the new Building Code.

\begin{tabular}{|c|c|c|}
\hline & $\begin{array}{l}\text { U-values } \\
\text { according to } \\
\text { GBR } 82 \\
{\left[\mathrm{~W} / \mathrm{m}^{2} \mathrm{~K}\right]}\end{array}$ & $\begin{array}{l}\text { U-values } \\
\text { according to } \\
\text { GBR } 2005 \\
{\left[\mathrm{~W} / \mathrm{m}^{2} \mathrm{~K}\right]}\end{array}$ \\
\hline Light outer walls (weight $<100 \mathrm{~kg} / \mathrm{m}^{2}$ ) & 0.30 & 0.20 \\
\hline $\begin{array}{l}\text { Heavy outer walls (weight }>100 \mathrm{~kg} / \mathrm{m}^{2} \text { ) and } \\
\text { basement walls towards ground }\end{array}$ & 0.40 & 0.30 \\
\hline $\begin{array}{l}\text { Partition walls next to spaces that are unheated to a } \\
\text { temperature that is more than } 8^{\circ} \mathrm{C} \text { lower than the } \\
\text { temperature in the space in question }\end{array}$ & 0.50 & 0.40 \\
\hline $\begin{array}{l}\text { Separating floors next to spaces that are unheated } \\
\text { or are heated to a temperature that is more than } 8^{\circ} \mathrm{C} \\
\text { lower than the temperature in the space in question }\end{array}$ & - & 0.30 \\
\hline $\begin{array}{l}\text { Separating floors above the open or in ventilated } \\
\text { crawl spaces, ground supported floors and } \\
\text { basement floors towards ground (without floor } \\
\text { heating) Heavy separating floors (weight }>100 \\
\mathrm{~kg} / \mathrm{m}^{2} \text { ) }\end{array}$ & $\begin{array}{l}0.20 \\
0.26\end{array}$ & $\begin{array}{l}0.20 \\
0.20\end{array}$ \\
\hline $\begin{array}{l}\text { Separating floors above the open or in ventilated } \\
\text { crawl spaces, ground supported floors and } \\
\text { basement floors towards ground (with floorheating) }\end{array}$ & - & 0.15 \\
\hline Ceiling and roof constructions & 0.20 & 0.15 \\
\hline Walls separating habitable space from roof space & 0.30 & 0.15 \\
\hline Sloping walls directly against roof & 0.20 & 0.20 \\
\hline Flat roofs & - & 0.20 \\
\hline Windows & 2.90 & 1.80 \\
\hline Outer doors, gates and hatches towards the open & 2.00 & 1.80 \\
\hline $\begin{array}{l}\text { Skylights and glazed curtain walls towards the open } \\
\text { or towards rooms heated to a temperature more } \\
\text { than } 8^{\circ} \mathrm{C} \text { lower then the temperature in the space in } \\
\text { question }\end{array}$ & - & 1.80 \\
\hline $\begin{array}{l}\text { Maximum linear loos } \Psi[\mathrm{W} / \mathrm{mK}] \text { in assembly } \\
\text { between }\end{array}$ & & \\
\hline - foundation/base and floor (without floorheating) & - & 0.25 \\
\hline - foundation/base and floor (with floor heating) & - & 0.20 \\
\hline - outer wall and window, outer door or gate/hatch & - & 0.03 \\
\hline - roof and window in roof or skylight & - & 0.10 \\
\hline
\end{tabular}

\section{Energy frame}

The energy frame implies the maximum allowed yearly net heating needed for heating and ventilation per $\mathrm{m}^{2}$ floor area of heated space. The demands for thermal insulation are seen as kept - even thought the U-values and $\Psi$-values are changed and the total window and outer door area is increased - as long as the required energy supply to heating and ventilation does 
not exceed the energy frame. The separate building components must anyhow always be insulated according to the maximum-values of $U$ and $\Psi$.

For dwellings in the Building Code there are two energy frames- one for building south of the polar circle (zone 1) and one for north of the polar circle (zone 2). This zone split takes into account the climate variations from south to north.

Zone 1: $420+\frac{280}{\mathrm{e}}\left[\mathrm{MJ} / \mathrm{m}^{2}\right]$ pr. year Zone 2: $510+\frac{325}{\mathrm{e}}\left[\mathrm{MJ} / \mathrm{m}^{2}\right]$ pr. year

where e is the number of storeys.

Table 2: $\quad$ Energy frames.

\begin{tabular}{ccccc}
\hline No. of storeys & \multicolumn{2}{c}{ Zone 1 } & \multicolumn{2}{c}{ Zone 2 } \\
& {$\left[\mathrm{MJ} / \mathrm{m}^{2}\right]$} & {$\left[\mathrm{kWh} / \mathrm{m}^{2}\right]$} & {$\left[\mathrm{MJ} / \mathrm{m}^{2}\right]$} & {$\left[\mathrm{kWh} / \mathrm{m}^{2}\right]$} \\
\hline 1 & 700 & $\sim 194$ & 835 & $\sim 232$ \\
\hline $11 / 2$ & 620 & $\sim 172$ & 745 & $\sim 207$ \\
\hline 2 & 540 & $\sim 150$ & 650 & $\sim 181$ \\
\hline 3 & 515 & $\sim 143$ & 620 & $\sim 172$ \\
\hline 4 & 490 & $\sim 136$ & 595 & $\sim 165$ \\
\hline
\end{tabular}

The energy frame is determined from climate data measured through-out a long period, so the energy frame correspond to the energy consumption in the reference building, which has building components with U-values and $\Psi$-values (standard-values) according to the Building Code, and which has mechanical ventilation according to the ventilation requirements for dwellings. Energy contributions from solargains through windows are taken into account.

\section{REFERENCES}

- Beregning af bygningers varmetab. DS 418, 6. udg. Dansk Standard. 2002.

- Forskrifter for beregning af bygningers varmetab. Grønlands Hjemmestyre. 1995.

- Grønlands Bygningsreglement 1982. Grønlands Hjemmestyre. Inkl. Tillæg 1.

- Grønlands Bygningsreglement. Direktoratet for Boliger og Infrastruktur. Grønlands Hjemmestyre. 2002. Forslag.

- Kragh, J.; S. Svendsen. 2002. Analyser til det ny grønlandske bygningsreglement. BYG·DTU, Danmarks Tekniske Universitet.

- Kragh, J.; G. Reimann; S. Svendsen. 2004. Mekanisk ventilation med varmegenvinding $i$ arktisk klima. BYG·DTU, Danmarks Tekniske Universitet.

- Kragh, J.; J. Rose; S. Svendsen. 2003. Beregning af bygningers varmebehov $i$ Grønland. BYG·DTU, Danmarks Tekniske Universitet. Anvisning. 


\title{
Holistic design
}

\section{with focus on structural functions and thermal bridges}

\author{
Per Kjærbye, Associate Professor, Structural and Building Design, Department of Civil \\ Engineering, Technical University of Denmark, pok@byg.dtu.dk
}

\section{INTRODUCTION}

Designing buildings calls for holistic thinking and co-operation in the total design process.

Holistic thinking means to take into consideration all relevant functional requirements, such as statical demands, acoustical behaviour, thermal and moisture resistances, fire precaution, and other requirements related to f.inst. extreme climatic conditions, special use of the building, but also focusing on easy operation and maintenance of the final building.

Such global thinking should ensure that structures, components and joints are able to withstand all different loadings relevant for the building in question.

In many countries nowadays the building regulations are written in accordance with the above listed functional requirements acting as a useful design guide.

Co-operation between design architects and engineers is vital and necessary in order to obtain a sound building and to avoid costly and time consuming redesigns. In many cases parts of buildings are more and less designed two or three times, in the sense that the architectural design may be adjusted by the structural engineer, and later on in the process, the contractor or the producer of components may suggest some final adjustments based on their experiences.

Co-operation could be established via partnering or lean construction agreements to be formulated early in the design phase, initiated maybe by the client.

\section{GENERAL DESIGN PROCEDURES}

The design procedure for each and everyone of the functional requirements could in general terms be formulated as:

1. Load assessments

2. Definition of calculation model

3. Analysis.

Especially for the structural concept, procedures and actions will be:

1. Load tables and load estimates

2. Structural system, load path description, stiffness of components and joints, load combinations

3. Internal forces, reactions, stresses and deformations

ending up with the documentation in terms of specifications and production drawings.

Functional requirements for thermal resistance could be handled as:

1. Differences in temperature, outside/inside

2. Formulas for energy transportation, 1- or 2-dimensional heat flow

3. Evaluation of heat loss and thermal bridges

all to be compared with requirements in codes and building regulations.

A holistic design in practice will often be the art of compromising,- if one requirement in particular is high-lighted, other requirements will loose capacities. If f.inst. the load-bearing functions are focused on designing strong and stiff components and joints, the acoustic and 
the thermal requirements will be very difficult to fulfill. And if f.inst. a fire protection wall is efficiently joined with the roofing, the risk of thermal bridges is considerable.

\section{THE STRUCTURAL SYSTEM IN DTU-LOW ENERGY HOUSE IN SISIMIUT}

The main structural systems for walls, roof and slab in the low energy house, LEH, in Sisimiut are chosen as traditional timber structures, partly produced in the workshop, partly on the building site.

Plywood is used as cladding material on all components, which means that they structurally are able to act as diaphragms.

The foundation is made as cast-on-site concrete walls, with transverse foundation walls under gables, and longitudinal foundation walls in connection with the stiffening system above.

In order to define and thereby to understand the structural system and the overall load path, some drawings and sketches are shown in the following.

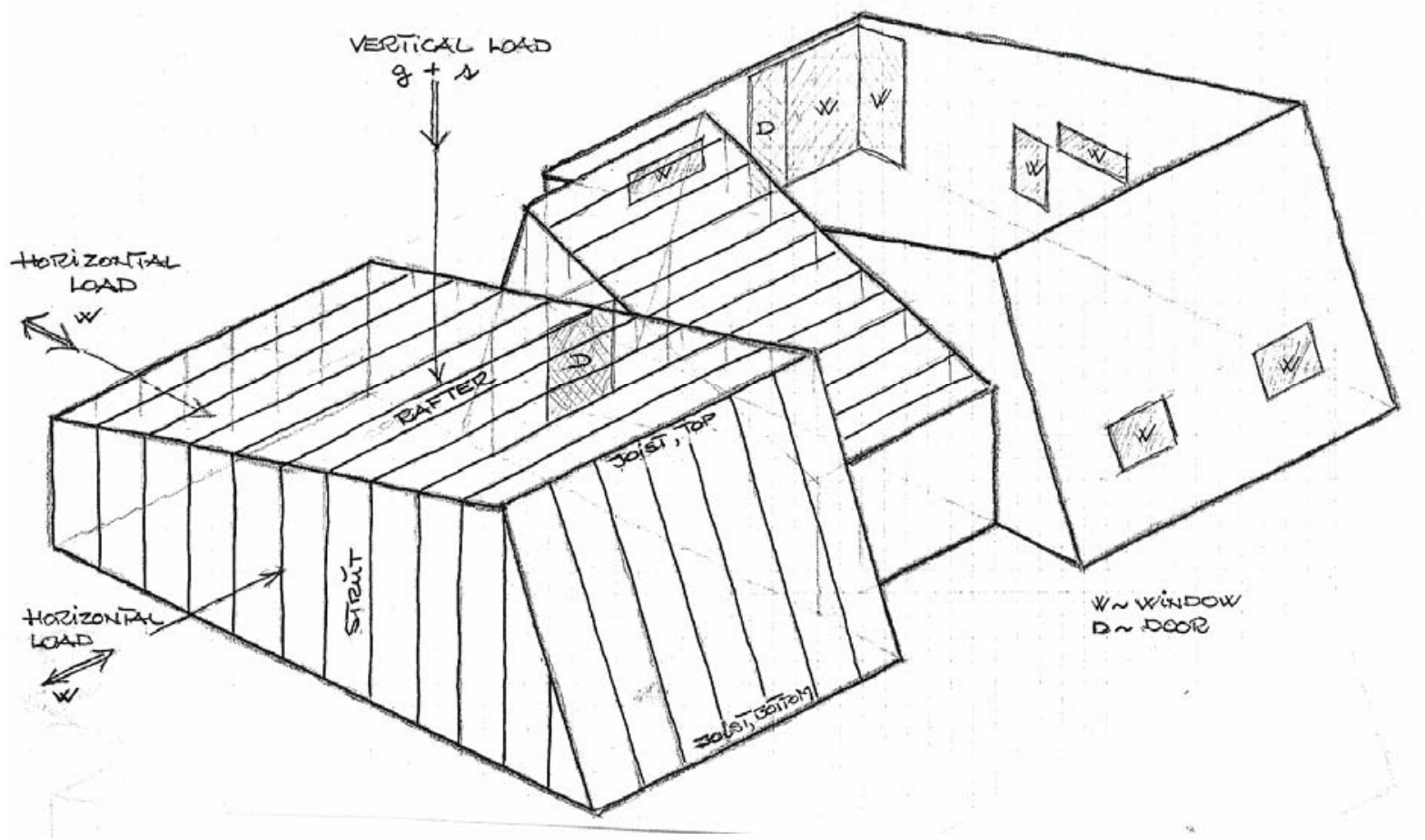

he first sketch presents the architectural and structural idea as an isometric drawing. The house is divided into three parts: two living boxes and a middle section. The living boxes act as separate houses linked with a common entrance area in between. 

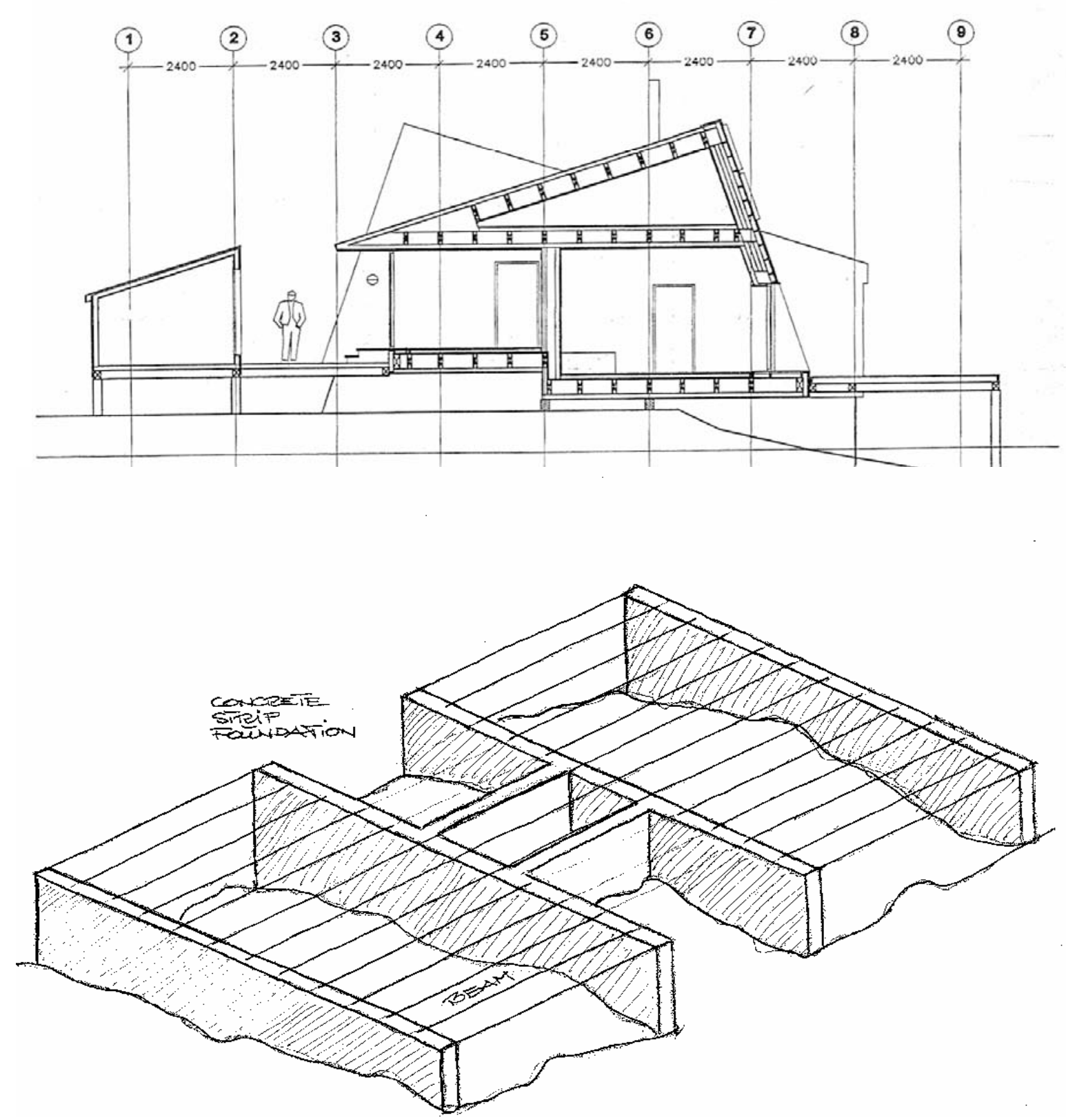

The second drawing is from the design architects' office showing a cross-section through the middle part of the house; the drawing also shows the contour of one of the main living boxes. Walls, roof and slab are all timber structures with 3-400 $\mathrm{mm}$ thermal insulation installed. The transverse concrete foundation walls run from modular line 3 to 8 , and the longitudinal foundation walls are positioned in line 5 and 6.

The third sketch describes the simple foundation system with crossing concrete walls. The openings under the facades will be partly closed by stone fillings kept in position by grids made of steel bars.

The house is structurally designed for self-weight, live load, snow load and wind forces. 
The load path for vertical loadings is: from a $\mathrm{m}^{2}$-load on the roof via the rafters to struts in the gable walls and further on to the corresponding foundation walls. Wind suction might lead to tensile joints between roof, gable walls and foundation walls.

The load path for horizontal loadings on the facades is: from $\mathrm{m}^{2}$-wind load on the facades to line-loads on the roof and the floor slab; plywood cladding in those structures will transfer the horizontal forces via diaphragm action in the gable walls to the foundation system.

The load path for horizontal loadings on the gables is exactly as the load path description for hori-zontal loadings on the facades, as all the exterior walls are built the same way.

\section{EXAMPLES ON STATICAL AND THERMAL DESIGN}

In the following two examples on interaction between statical and thermal functional requirements are shown, partly linked to the DTU-Low Energy House, LEH, in Sisimiut.

The first example deals with the assembly joint between a concrete strip foundation, the floor slab structure and the facade.

The second example evaluates the load-bearing capacity and the thermal capacity of a lightweight slab structure.

\section{EXAMPLE 1: ASSEMBLY DETAIL: FOUNDATION-SLAB-FACADE}

The attached figures show four stages in developing an acceptable compromise between the statical and the thermal functions when joining a concrete strip foundation, a concrete slab, and an exterior wall.

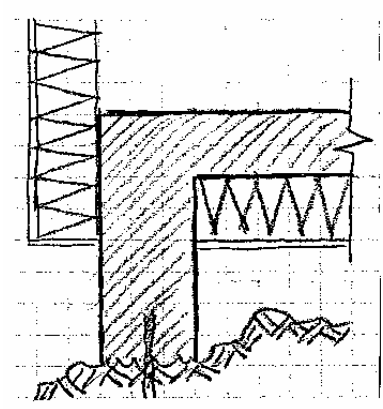

1.

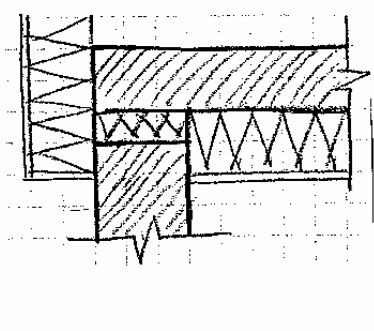

2.

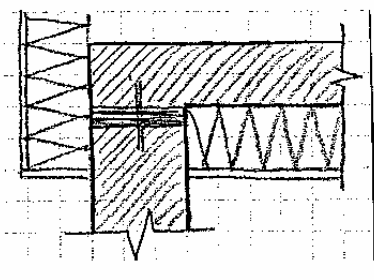

3.

4.

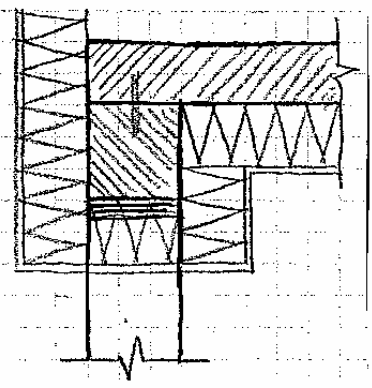

First the building parts are simply cast together. In stage two the thermal bridges are partly eliminated by making voids locally. Stage three has neoprene-strips installed in the bearing support between the slap and the foundation wall. Finally the structure is changed from a wall-slab joint to a column-beam-slab joint with neoprene material in the supporting area.

Supplementary the four assembly details above, the same detail from the LEH-project is shown at the end of this paper. The floor slab is in this project chosen as a timber-based structure using glued plywood-joists, and the facade is a skeleton structure with wooden struts; the foundation is again a concrete strip structure.

\section{EXAMPLE 2: LIGHT-WEIGHT SLAB STRUCTURE}

In the LEH-project a light-weight structure was chosen as floor slab. Due to thermal capacity the floor thickness should be a total of $350 \mathrm{~mm}$, and due to bearing capacity the floor joists spanning approx. 7 meters could be either $140 \times 300$ timber, $90 \times 300$ glued plywood, Ishaped wooden profile or C-profile in $2 \mathrm{~mm}$ steel. All those options are shown on the attached figures below.

The different light-weight structures will be compared due to heat loss and thermal bridges. 

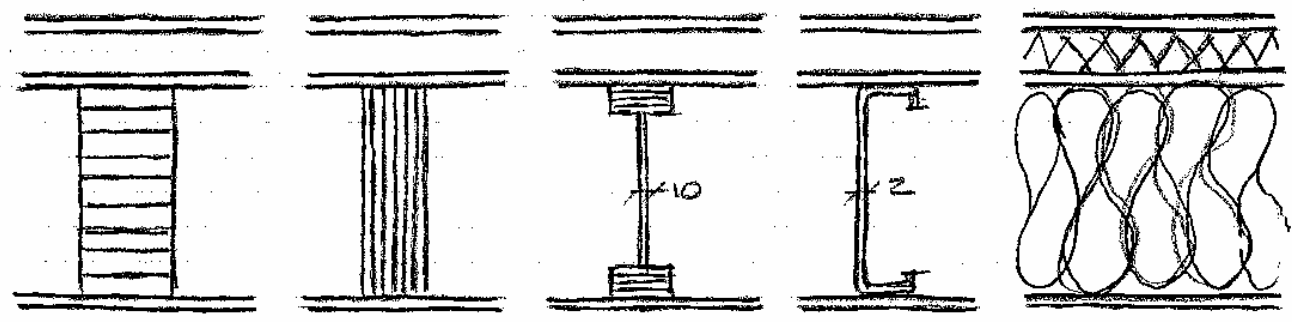

\section{AS BUILT-DETAIL: FOUNDATION-SLAB-FACADE}

The assembly detail below is from the designers catalogue showing the cast-on-site foundation wall, the light-weight slab structure based on glued plywood joists $90 \times 300$ with a total of $300+50=350 \mathrm{~mm}$ thermal insulation, and the facade with a double timber strut system with a total of $150+100+50=300 \mathrm{~mm}$ thermal insulation.

The thermal bridge will be evaluated and compared with the structures in example 2 .

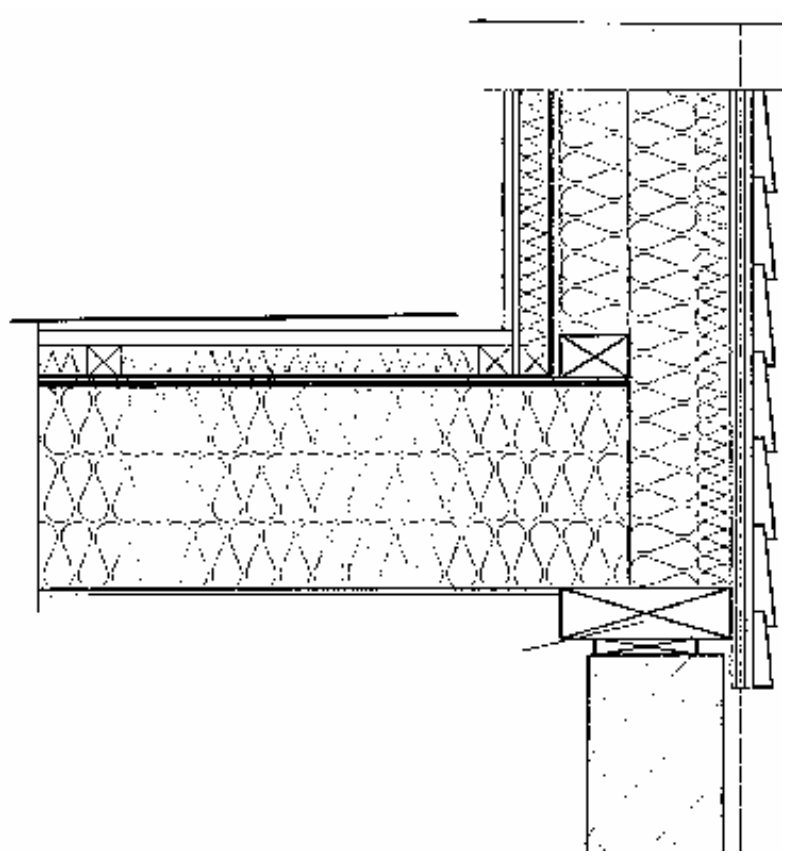




\section{The Low Energy House - Background, Accomplishment and Description of the Building}

Lars R. Kruse, Architect, Client consultant at the Technical university of Denmark (DTU), Campus Service.

According to the program for the symposium will the headline above be performed by two speakers: Mr. Jørn Hansen from Rambøll and the writer of this paper. The two of us has split the headline between us in this way: Background, accomplishment and history will be described by the writer of this paper; where as facts, technical description of the building will be described by Mr. Jørn Hansen from Rambøll.

\section{BACKGROUND}

The idea of building a low energy house in Sisimiut came about 5 years ago.

The thought was born around the time of the inauguration of the Arctic Technology Centre in Sisimiut in August 2000.

A brand new DTU house built in an arctic climate - primarily with the function as a research laboratory focused on low energy and moisture.

From the very start hopes and intentions has been to connect the teaching of the students from the Arctic Technology Centre at the local building and construction school with a real building project.

In this way both teachers and students could benefit from the idea - and even to some extent participate actively in an exiting experimental building project. Researchers from the DTU could at the same time test different innovative experiments. This project will in the long term strengthen and develop the knowledge of building in arctic climates. Thanks to the donation from the Villum Kann Rasmussen Foundation this new house became a reality.

\section{CONSULTANTS AND PROJECT HISTORY}

In connection with the donation from the Villum Kann Rasmussens Foundation there were formulated object clauses. In these it is described how it must be aimed at involving Greenlandic working capacity as much as possible.

This has been succeeded to a large extent and with a good result.

After the scheme concept phase were accomplished, long complicated negotiations with local counsellors took place concerning carrying out the final design phase.

After many negotiations and a cut in the economical budget the contract was finally signed. Rambøll Greenland was chosen as principal consultants. Through Rambøll's local knowledge the contact between the DTU and the local main contractor Arctic Sanasut aps was created. Arctic Sanasut aps has built the house in prime quality and with great success.

There has though been problems while building the house e.g.: All building materials to Greenland arrive from the Danish port of Aalborg - even if it is produced and manufactured in Finland like the load bearing beams in this house. The number of people and machinery involved in this cargo-chain sometimes suffers from the lack of reliability in the arrival times of materials . A fact that has caused some delay in the accomplishment of this building. 


\section{THE JOB OF THE CLIENT CONSULTANT}

The DTU Campus Service has been the Client Consultant through the whole project. It has been a great challenge and a unique interesting project to participate in.

Personally, I assumed the case with the low energy house in December 2003 and has since been the representative in the project from the DTU.

During the building period I have been visiting the site twice. First time was in the fall of 2004 and last during Winter in January 2005. Two very important visits where I had the honour of meeting the main contractor, the skilled Greenlandic craftsmen and the principal consultants Rambøll.

The climate in Greenland must be seen and felt - in all seasons - in order for one to be prepared to understand the complexity of building under arctic conditions.

From my trips to Greenland I have learned the importance of gaining knowledge of the local conditions - the ability to listen, understand and accept the existing local conditions. All this is essential when building a house in Greenland.

Client Consulting on a research building being built around $4000 \mathrm{~km}$ away from the DTU Campus tells a lot about the atypical in this case.

It has been my job to coordination and gather the many participants in the project. As the project has been through the hands of several consultants part of the job has been to coordinate and assure that this process succeeded. All this has been done in close cooperation with the DTU researchers, Rambøll as consultants and the main contractor Arctic Sanasut.

\section{THE PARTICIPANTS}

The list of persons involved in the building project is long - it is not possible to mention everyone in this paper but a few examples from the list of companies and people which have contributed with hard work on the innovative side follows here:

The Danish ventilation company Exhausto have created a new exiting system which I herby thank for. In close cooperation with the DTU researchers, a brand new special heat recovery system to be used in the arctic have been developed.

Another Danish company I wish to thank is the Danish window manufacture Velux. The manufacturer has made a special effort by delivering new developed low energy glass to the windows of the house, transported to Greenland from a factory in Japan.

It will be interesting to follow these new products when the house is being used.

Finally I would like to thank everyone who has participated actively in realizing this exiting house. A special thank to the contractor and the local craftsmen. They have transformed theory, drawings and descriptions into practise. And the result speaks for itself - a small architectural pearl in high quality..

I am sure that the house will function as a catalyser for many other innovative future initiatives - not 'just' in Greenland but many other places with arctic climates.

Congratulations on the house. 


\title{
The Low Energy House - Facts and Technical Description of the Building
}

\author{
Jørn Hansen, Director, Rambøll Greenland
}

The low energy house in Sisimiut was handed over February $4^{\text {th }} 2005$ and it is arranged with 2 apartments with kitchen, bathroom, living room and two rooms. They have common entrance and technician room - all in all around $220 \mathrm{~m}^{2}$.

The background for the building of the low energy house is the donation of 5 million DKK from the Villum Kann Rasmussen Foundation and a promise from the municipality in Sisimiut of defraying the costs for land development - appr. 100.000 DKK.

The work started with an approach to us, RAMBØLL Greenland, for us to participate with our knowledge of Greenlandic building. This knowledge was in the first place available from the largest consultancy companies in Greenland; INUPLAN, TEGNESTUEN NUUK, SARFAA and RAMBØLL Greenland.

The many inputs Rambøll Greenland were given to the project manager, Erik Møllers Tegnestue in Denmark, and a project proposal was drawn up.

After the completion of this work Rambøll Greenland was asked to tender the task amongst local contractors in total enterprise on the given basis.

The offering-material with special definitions, distributing-lists, time-schedule etc., was sent out and the call for tenders was held but unfortunately with a result which exceeded the budget - a square-meter-price of slightly more than $27.000 \mathrm{DKK}$ - corresponding to a total construction cost of 6 mio. DKK.

Naturally the task could not be completed on this background and it was decided to try to get a negotiated solution through.

This negotiation happened with the firm which just now has delivered the house - Arctic Sanasut ApS att Per Sværd.

The negotiation meant that apart from the large insulation thickness, the building has complete ventilation with heat recovery and solar collector system for the hot water supply and heating of the porch.

The whole house is supplied with floor heating.

The construction time has been approximately 10 months from start to delivery.

Other materials are, as far as the constructions are concerned, common wood kerto-frames and plywood as stiffened disks and foundation for internal plaster-cladding. There is applied Tyvek-moisture-membrane underneath the external cladding and there is Red-Wood clinkercladding.

The foundation is carried out with concrete-slabs and with an open crawl space to have the possibility to investigate this method's influence on the energy balance of the building. 
The building has a lot of sensors for measuring moisture - 30 in all - placed in and on the construction to give possibilities for measuring-series and studies of the moisture-conditions in the construction, which give the possibility that in future consulting, we can improve for example the techniques of solving thermal bridge problems in wood-constructions and moisture related problems in buildings.

Moreover there are placed a lot of energy-metres for measuring the consumption of floorheating in each building, for measuring the sun collector's production and the oil-burner's production, so that studies in the energy balance between the different producing and using units can be made.

\section{Economy}

All expenses associated with design, construction management and inspection, built-in sensors, and all expenses for the contractors etc. have been covered by the grant from:

Villum Kann Rasmussen Foundation:

Mio $\mathrm{Kr}$.

Municipality of Sisimiut

Mio $\mathrm{Kr}$.

0.10

In total:

Mio Kr. $\quad 5.10$ 


\title{
Energy performance of the low-energy house in Greenland
}

Jesper Kragh, Assistant Professor, Department of Civil Engineering, Technical University of Denmark, jek@byg.dtu.dk

Svend Svendsen, Professor, Department of Civil Engineering, Technical University of Denmark, ss@byg.dtu.dk

\begin{abstract}
The object of the low-energy house in Sisimiut in Greenland was to build a house with an energy consumption less than $80 \mathrm{kWh} / \mathrm{m}^{2}$ corresponding to half the energy frame of the coming building code. Therefore the focus in this project has been on large insulation thicknesses, windows with high net energy gain, efficient ventilation system with heat recovery and solar heating.

In this paper the results of a calculation of the energy consumption of low-energy house is presented. The calculation was done using the program BSim2002 [1] and a new weather test reference year based on climatic data measured over the last ten years in Sisimiut [2].

The calculations have shown that the $200 \mathrm{~m}^{2}$ double-family house has an annual energy consumption less than $80 \mathrm{kWh} / \mathrm{m}^{2}$, which is $50 \%$ lower than the requirement by the revised building code for 2005 . The low energy consumption is attained primarily by ventilation heat recovery ( $90 \%$ efficiency) specially designed for arctic conditions, by using thicker insulation in walls $(300 \mathrm{~mm})$ and roof/floor $(350 \mathrm{~mm})$, and by using solar hot water heating (3250 $\mathrm{kWh} /$ year). The building is intended to enhance sustainability in the building sector in Greenland.
\end{abstract}

\section{INTRODUCTION}

The Low-energy house is to be the start of a general development of sustainable buildings in Greenland - a new style of building that isn't based on fossil fuels (oil). In the long term there is a need for buildings that both secure a good indoor climate and protects against the harsh cold outside climate and not depending of problematic oil delivery.

As the life time of buildings is long there is a good reason to implement a development of buildings without a need for oil delivery.

The Low-energy house shows that the energy consumptions can be reduced significantly (50 $\%$ of the energy frame demand) using today's best energy saving building components. By further development of more energy saving building components it is expected that the energy consumption could be reduced another $50 \%$. The rest of the energy demand is expected to be delivered by heat and electricity production based on solar heating systems, photovoltaic systems, wind mills, hydro-electric power station (waterpower) and waste incineration.

Buildings without oil demand aren't realistic to build without extra costs in the constructions expenses but looking at the entire lifetime of the house, 100 years, the sustainable building is expected to be a good investment.

The challenge in the development of energy sustainable buildings is to start of the development and here it is the hope that the Low-energy house in Sisimiut will promote and encourage this process. 


\section{THE LOW-ENERGY HOUSE}

In the following the low-energy house is described. The house is approximately $200 \mathrm{~m}^{2}$ and is actually build as a double house with common scullery and entrance hall. In Figure 1 and Figure 2 the house floor plan and cross section is shown respectively.

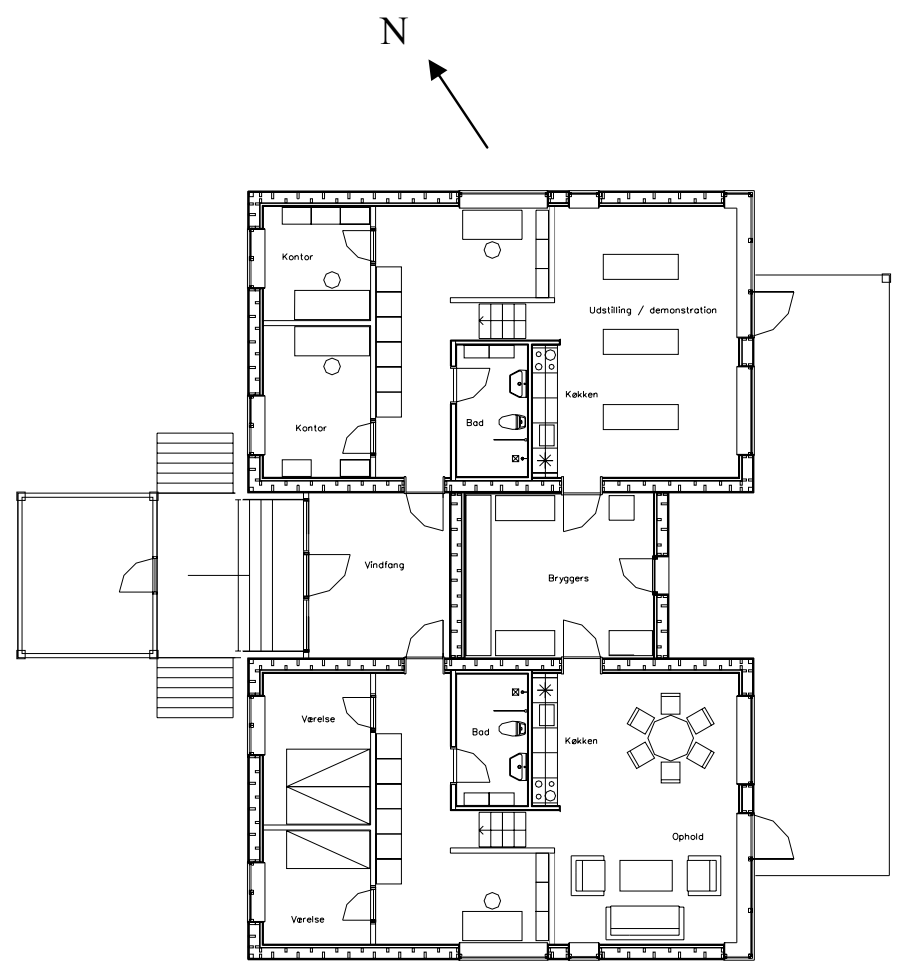

Figure 1 Floor plan of the low-energy house. The low-energy house is actually a double house with common scullery and entrance hall.

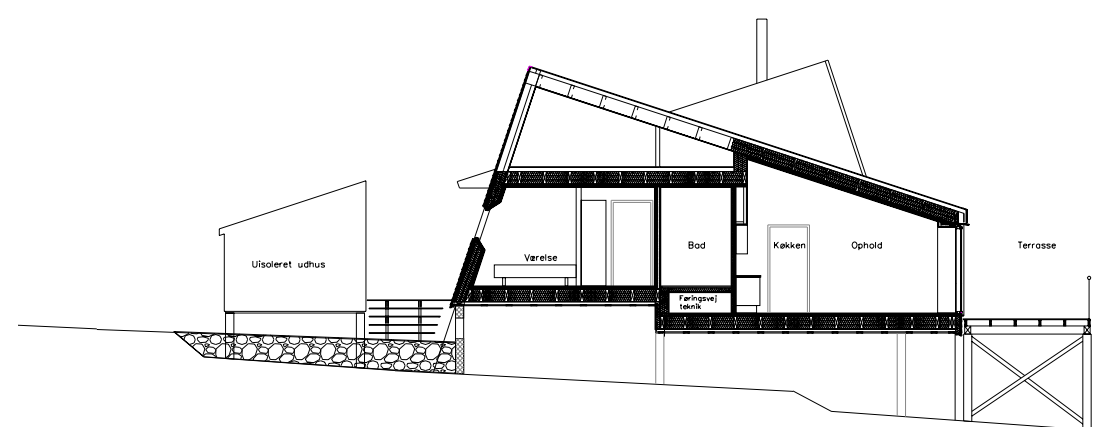

Figure 2 Cross section of the Low-energy house. 


\section{THE BUILDING ENVELOPE}

The heat loss due to thermal transmittance of the building envelope constructions is reduced by use of increased insulation thicknesses and wood profiles with minimum thermal bridge effect.

\section{Thermal transmittance of building envelope constructions}

In Table 1 calculated values of the main constructions U-values are compared with the demands in the coming building code of Greenland.

Table 1 Calculated U-values of the different constructions compared with the demands from the coming building code of Greenland.

\begin{tabular}{lccc}
\hline Construction & $\begin{array}{c}\text { Insulation thickness } \\
{[\mathrm{mm}]}\end{array}$ & $\begin{array}{c}\text { U-value calculated } \\
{\left[\mathrm{W} / \mathrm{m}^{2} \mathrm{~K}\right]}\end{array}$ & $\begin{array}{c}\mathrm{U} \text {-value demand } \\
(\mathrm{GBR}) \\
{\left[\mathrm{W} / \mathrm{m}^{2} \mathrm{~K}\right]}\end{array}$ \\
\hline Floor & 350 & 0.14 & 0.15 \\
\hline Wall & 300 & 0.15 & 0.20 \\
\hline Roof & 350 & 0.13 & 0.15 \\
\hline
\end{tabular}

As it can be seen from Table 1 all the constructions have U-values below the coming demands.

\section{Thermal bridge effect in outer wall corners}

In Figure 3 a model of the outer wall corner is shown. The model is made to analyze how the corners (assembly) influences the heat transmission loss also called the linear thermal transmittance.
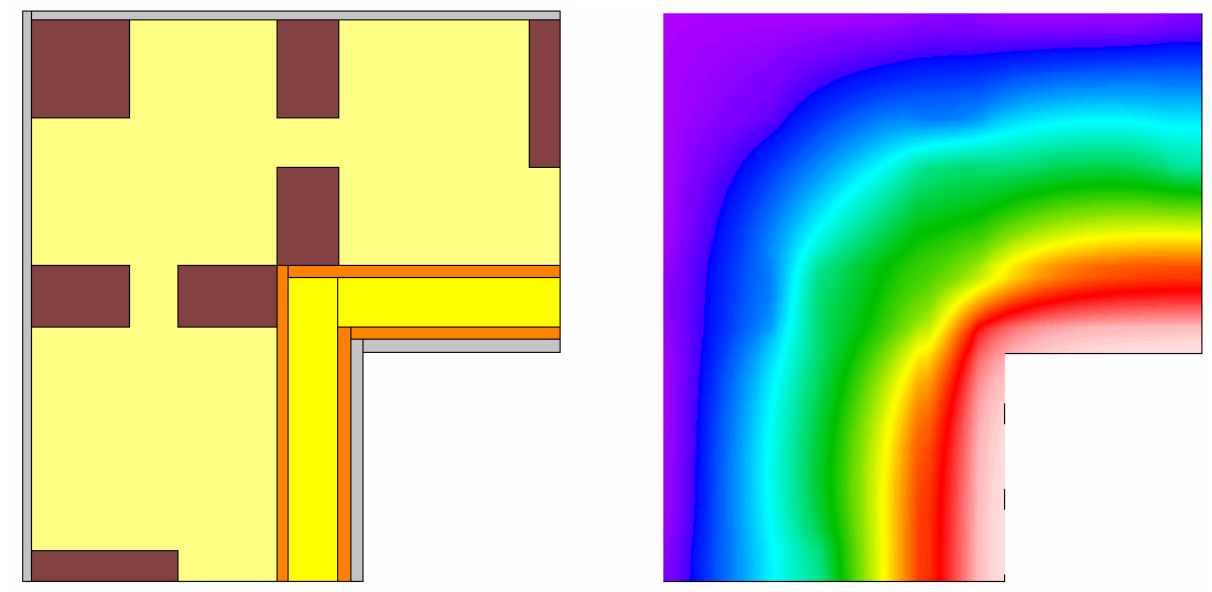

Figure 3 Simulation model of the outer wall corner. To the right a temperature plot

It is seen that the wood profiles are broken up into an internal and external part which will minimize the heat loss. The calculated linear thermal transmission coefficient is $0.015 \mathrm{~W} / \mathrm{mK}$ which is assessed to be acceptable.

\section{WINDOWS}

Three types of glazing units are used and tested in the low-energy house:

Type 1: 1+2 solution: Made of one single glass with a hard low emission coating and a double low energy glazing unit. 
Type 2: Combined double energy glazing and a vacuum glazing unit.

Type 3: 2+1 solution: Made of one double energy glazing and one single glass with a hard low emission coating.

The three glazing units are shown in Figure 4.

Type 1

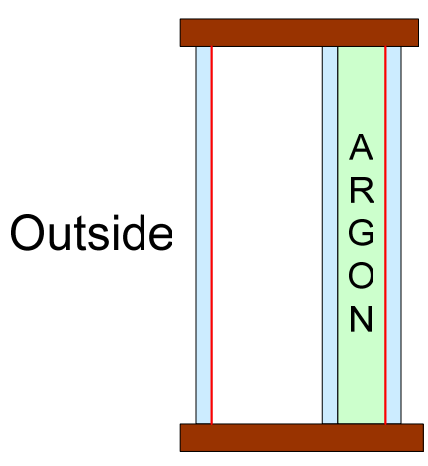

Type 2

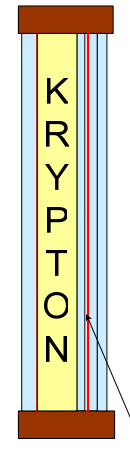

Type 3

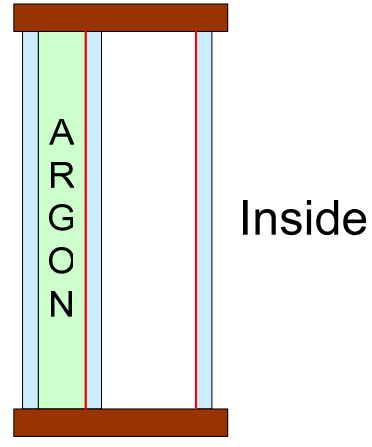

\section{Vacuum}

Figure 4 The three glazing units tested in the low-energy house

In Table 2 the data of the glazing units are shown. The net energy gain is calculated as a mean value of windows orientated north, east, west and south for a reference house.

Table 2 Heat transmission coefficient $\left(\mathrm{U}_{\mathrm{g}}, \mathrm{U}_{\mathrm{w}}\right)$, solar energy transmission $\left(\mathrm{g}_{\mathrm{g}}, \mathrm{g}_{\mathrm{w}}\right)$ and net energy gain $\left(\mathrm{Q}_{\mathrm{g}}, \mathrm{Q}_{\mathrm{w}}\right)$. Index $\mathrm{g}$ for glazing and $\mathrm{w}$ for window.

\begin{tabular}{lcccccr}
\hline Type & $\begin{array}{c}\mathrm{U}_{\mathrm{g}} \\
\mathrm{W} / \mathrm{m}^{2} \mathrm{~K}\end{array}$ & $\begin{array}{c}\mathrm{g}_{\mathrm{g}} \\
-\end{array}$ & $\begin{array}{c}\mathrm{Q}_{\mathrm{g}} \\
\mathrm{kWh} / \mathrm{m}^{2}\end{array}$ & $\begin{array}{c}\mathrm{U}_{\mathrm{w}} \\
\mathrm{W} / \mathrm{m}^{2} \mathrm{~K}\end{array}$ & $\begin{array}{c}\mathrm{g}_{\mathrm{w}} \\
-\end{array}$ & $\begin{array}{c}\mathrm{Q}_{\mathrm{w}} \\
\mathrm{kWh} / \mathrm{m}^{2}\end{array}$ \\
\hline 1: $1+2$ & 0.7 & 0.45 & 172 & 1.0 & 0.30 & -17.3 \\
\hline 2: $2+$ Vak.rude & 0.7 & 0.40 & 136 & 1.1 & 0.27 & -59.3 \\
\hline 3: $2+1$ & 0.8 & 0.56 & 228 & 1.1 & 0.47 & 67.1 \\
\hline
\end{tabular}

\section{HEATING SYSTEM}

The low-energy house is constructed with floor heating based on PEX-tubes installed in aluminum plates just below the wood floor covering. In the toilet the floor heating system is based on PEX-tubes in the concrete.

\section{CALCULATION OF THE ENERGY BALANCE OF THE LOW-ENERGY HOUSE}

As the low-energy house is a double house made as two equal houses with common scullery and entrance hall the calculation model is simplified to only one of the "houses". The model is shown in Figure 5. 


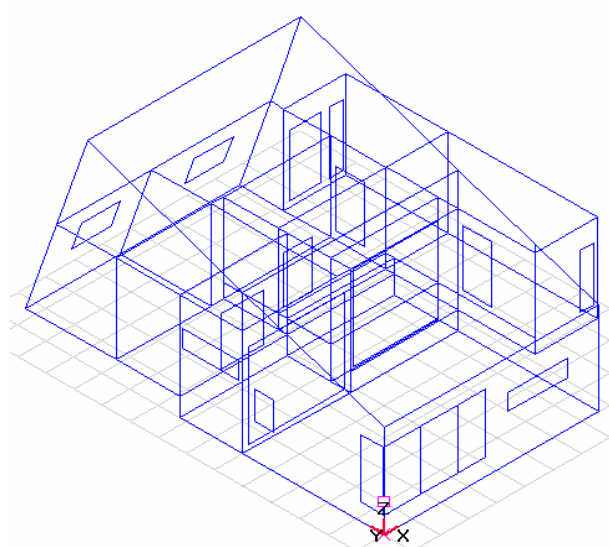

Figure 5 Calculation model of the low-energy house

In Figure 6 the calculation results of the low-energy houses energy flows is presented using weather data from Sisimiut. In the calculation the set point temperature of the heating system was $21^{\circ} \mathrm{C}$ in all rooms except the two bathrooms were $23^{\circ} \mathrm{C}$ were used. The internal heat gain was calculated to be $5 \mathrm{~W} / \mathrm{m}^{2}$ and the infiltration was $0.1 \mathrm{~h}^{-1}$. The total ventilation rate was 45 $1 / \mathrm{s}$ according to the demands in the building code.

The results are compared with the expected energy frame demands in the coming building code of Greenland. For a house with a mechanical ventilation system with or without heat recovery the energy frame demands are expected to be 160 and $220 \mathrm{kWh} / \mathrm{m}^{2}$ respectively.

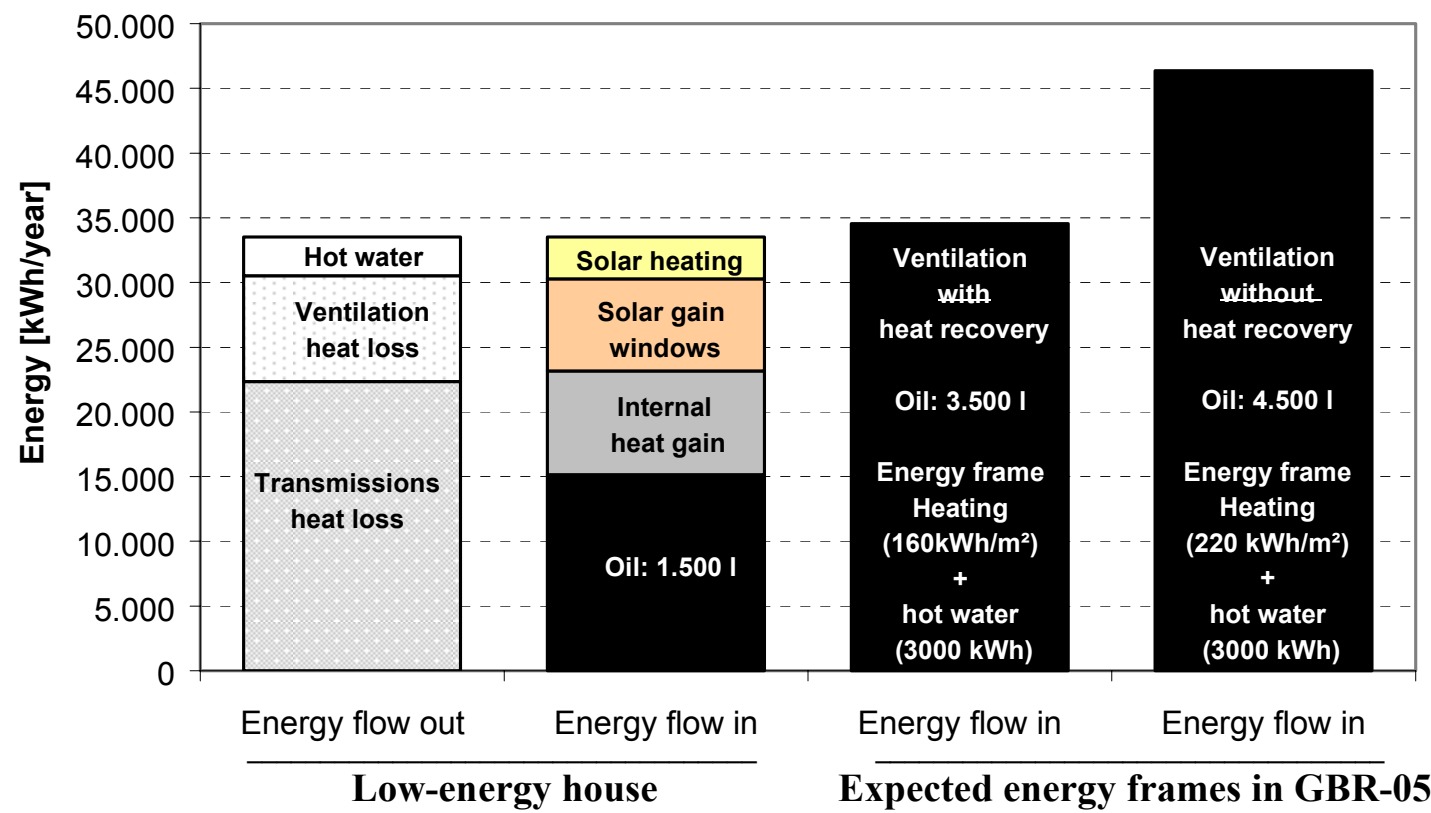

Figure 6 Energy balance of the $200 \mathrm{~m}^{2}$ low-energy house compared with the expected demand of the building code GBR05.

It is seen that the low-energy house energy consumption is simulated to be approximately 1.500 liters of oil a year. Compared with the expected energy frames in the coming building code it is seen that 3.000 liters of oil is saved every year. 
The result of the simulation shows that the annular energy consumption of the Low-energy house is below the goal of $80 \mathrm{kWh} / \mathrm{m}^{2}$.

\section{CONCLUSION}

The object of the low-energy house in Sisimiut in Greenland was to build a house with an energy consumption less than $80 \mathrm{kWh} / \mathrm{m}^{2}$ which is shown by detailed simulation to be fulfilled. The low energy consumption was achieved by using thicker insulation in walls and roof and floor, windows with high net energy gain and by using ventilation with effective heat recovery and solar hot water heating.

\section{ACKNOWLEDGEMENT}

The Villum Kann Rasmussen Foundation financed the work presented in this paper.

\section{REFERENCES}

BSIM 2002: Integrated software for thermal analysis of buildings and installations.

Statens Byggeforskningsinstitut, 2002, Danmark.

Test Reference Year, Sisimiut (TRY), ASIAQ, Nuuk, Greenland, 2004. 


\title{
Evacuated Tubular Collectors
}

Louise Jivan Shah, Assoc. Professor, Department of Civil Engineering Technical University

of Denmark, ljs@byg.dtu.dk

\begin{abstract}
In this paper two research examples on evacuated tubular collectors are given. The first example concerns development of theoretical models for Heat pipe evacuated tubular collectors. In the second example heat transfer and flow structures inside All-glass evacuated tubular collectors for different operating conditions are investigated by means of Computational Fluid Dynamics (CFD).
\end{abstract}

\section{INTRODUCTION}

Solar energy is a clean and natural energy source. The solar radiation on earth including at Arctic latitudes - is so large that it is possible to utilize solar energy in large scale.

The yearly number of hours with possibility of sunshine is almost independent of the latitude. However, Fig. 1 and Fig. 2 show that the distribution of the solar radiation on a monthly basis strongly depends on the latitude. At northern latitudes:

- more solar radiation occurs during the summer months

- the sun altitude is lower

- the day length variation is larger

For example, north of the Arctic Circle in the summer the sun is present 24 hours a day and solar radiation occurs from all directions during the 24 hours.

\section{Evacuated tubular collectors}

When solar collectors are developed for Arctic conditions, it is an advantage if the collector design can utilize solar radiation from all directions. Due to low ambient temperatures it is also an advantage if the

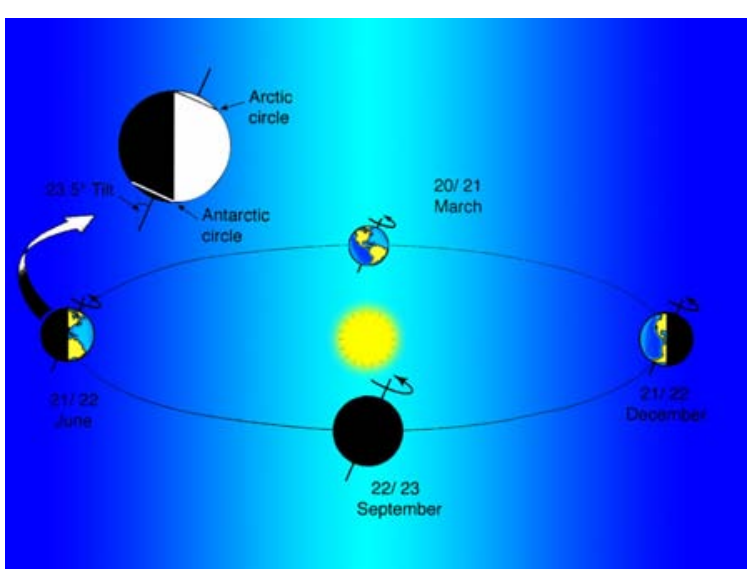

Fig. 1: The earth's path around the sun.

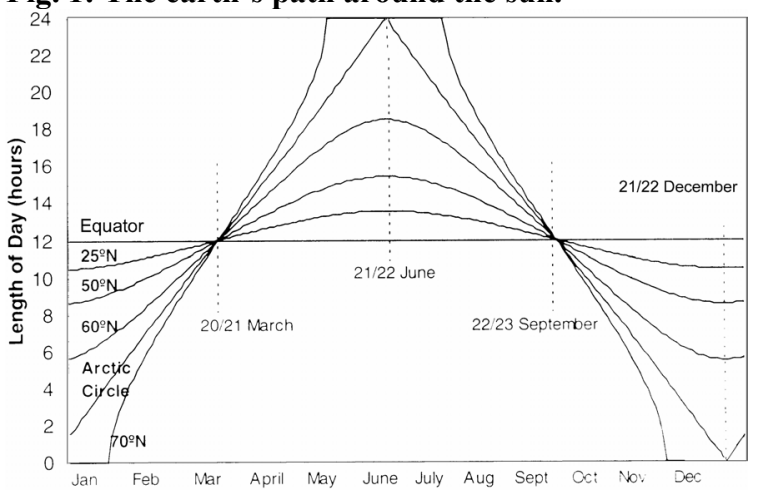

Fig. 2: The day length as a function of latitude and the season.

collector has a low heat loss so that as little as possible of the absorbed solar radiation is lost to the surroundings. Further, the collector must be able to utilize ground reflected radiation, as the snow on the ground has a large reflection coefficient. Evacuated tubular collectors can be designed to fulfil these demands. Basically there exist two types of evacuated tubular collectors: 
Heat pipe evacuated tubular collectors consist of cylindrical evacuated glass tubes which are connected to a condenser/heat exchanger unit. Inside the evacuated tubes are the absorber fins with selective coatings on the surfaces and with a heat pipe, which contains the working fluid, for example water. The working fluid evaporates at a low temperature when the absorber is heated by the solar radiation. The evaporated fluid rises in the pipe and condenses on the condenser in the heat exchanger unit. Thus the energy is transferred to the solar collector fluid, which is pumped through the condenser/heat exchanger unit. When the working fluid in the heat pipe condenses, it drops down in the heat pipe again and the whole process is repeated if the temperature is high enough. Fig. 3 shows an evacuated glass tube with a heat pipe.

All-glass evacuated tubular collectors are designed in a different way. They are based on double glass tubes (see Fig. 4) with the evacuated space between the glass tubes. The outside of the inner glass wall is treated with an absorbing selective coating and works as the absorber. With solar irradiation on the tube, the inner glass tube gets very hot. The heat can be transferred from the inner glass tube to the solar collector fluid in different ways: Either the solar collector fluid is flowing directly inside the inner glass tube or the solar collector fluid can flow in a metal pipe, which is in good thermal contact with the inner glass tube.

Evacuated tubular collectors are suitable for Arctic conditions as:

- The collectors have a low heat loss coefficient. Due the evacuated space in both types of evacuated tubular collectors, the heat loss due to convection and conduction is very small. Therefore, the heat loss from evacuated tubular collectors is lower than the heat loss from traditional flat plate collectors.

- The collectors can utilize solar radiation from all directions. All-glass evacuated tubular collectors have cylindrical absorbers and in Heat pipe evacuated tubular collectors the absorber fin can have a curved shape, which follows the shape of the glass tube.

- The curved/cylindrical absorber shape can further utilize the ground reflected radiation better.

In order to develop optimum designed evacuated tubular collectors for Arctic conditions detailed background research is needed. In chapter 2 and 3 two research examples are given. The first example concerns development of theoretical models for Heat pipe evacuated tubular collectors. In the second example heat transfer and flow structures inside All-glass 
evacuated tubular collectors for different operating conditions are investigated by means of Computational Fluid Dynamics (CFD).

\section{RESEARCH EXAMPLE 1: HEAT PIPE EVACUATED TUBULAR COLLECTORS}

In this example, two designs of heat pipe

$100 \mathrm{~mm}$

$100 \mathrm{~mm}$

evacuated tubular collectors are investigated theoretically. The absorber fins in the evacuated tubes are either flat or curved and the fins have selective coating on both sides. This means that solar radiation from all directions can be utilized. An illustration of the evacuated tubes is given in Fig. 5. The tubes are connected to a heat exchanger manifold pipe where condensers for all tubes are placed.

Two new TrnSys [1] models for collectors with evacuated tubes with flat and curved fins are developed. The models take solar radiation from all directions into account. Further, due to the cylindrical tubes, depending on the position of the sun and the distance between the tubes, the tubes will be able to cast shadow on each other as illustrated in Fig. 6 and the solar irradiance can vary along the fin. For the curved fin model, the irradiance always varies along the fin as the incidence angle varies along the fin. Due to the variation in the solar irradiances along the fins, the traditional fin efficiency cannot be applied. Therefore, the heat transfer processes in the fin are solved in detail.

With the models, a parameter sensitivity analysis is carried out for the ground mounted evacuated tubular collectors installed in a solar heating plant. This analysis illuminates how the:

- different fin geometries

- collector tilt

- operating temperature

- tube distances

- distances between collector rows

influence the yearly thermal performance of the collector field.

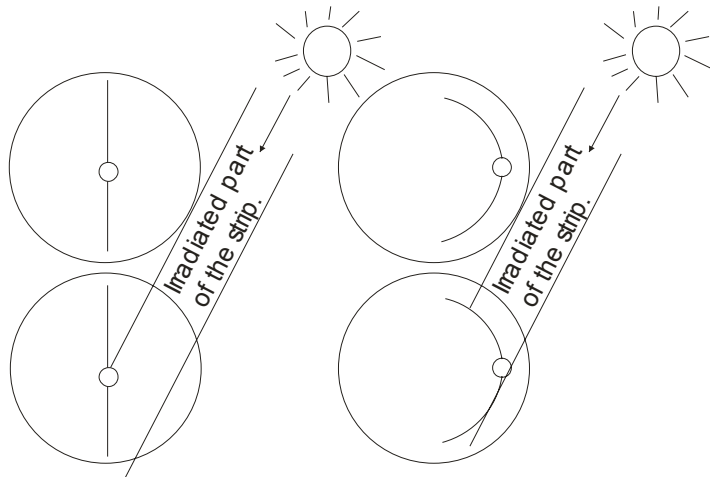

Fig. 6: The irradiated part of the fin for a given position of the sun.

\section{Theory and definitions}

In this section, the theory of the two collector models, for flat and curved fins respectively, will be summarized. The models are developed for the TrnSys simulation program. The models include both the evacuated tubular collectors and the heat exchanger manifold pipe, as illustrated in Fig. 7. 
The power, $\mathrm{P}_{\underline{u}}$, from this system can be written as:

$$
\begin{aligned}
& \mathrm{P}_{\mathrm{u}}=\mathrm{m} \cdot \mathrm{c}_{\mathrm{p}} \cdot\left(\mathrm{T}_{\text {manifold,outlet }}-\mathrm{T}_{\text {manifold,inlet }}\right) \\
& \mathrm{P}_{\mathrm{u}}=\mathrm{P}_{\text {ETC }}-\mathrm{P}_{\text {loss }}-\frac{\mathrm{dQ}_{\text {manifold }}}{\mathrm{dt}}
\end{aligned}
$$

The power from the heat pipes, $\mathrm{P}_{\mathrm{ETC}}$, the heat loss from the manifold tube, $\mathrm{P}_{\text {loss, }}$, and the energy change in the manifold tube, $\mathrm{dQ}_{\text {manifold, }}$ can be written as:

$$
\begin{aligned}
& \mathrm{P}_{\mathrm{ETC}}=\mathrm{UA}_{\text {manifold }} \cdot\left(\mathrm{T}_{\text {heatpipe }}-\mathrm{T}_{\text {manifold }}\right) \\
& \mathrm{P}_{\text {loss }}=\mathrm{U}_{\text {loss }} \cdot\left(\mathrm{T}_{\text {manifold }}-\mathrm{T}_{\text {amb }}\right)
\end{aligned}
$$

with

$\mathrm{T}_{\text {manifold }}=\frac{\mathrm{T}_{\text {manifold,inlet }}+\mathrm{T}_{\text {manifold,outlet }}}{2}$

The power from the heat pipes, $\mathrm{P}_{\mathrm{ETC}}$, is larger than zero if the temperature of the heat pipe working fluid, $\mathrm{T}_{\text {heatpipe, }}$ is larger than the lowest evaporation temperature and larger than the mean temperature in the manifold pipe, $\mathrm{T}_{\text {manifold. }}$ In other cases, $\mathrm{P}_{\mathrm{ETC}}$ is zero. In order to determine the temperature of the heat pipe working fluid, the fin is discretized into a number of elements as illustrated in Fig. 8. The energy balances for the elements of the fin are:

$\mathrm{i}=1$ :

$$
\begin{aligned}
& -\frac{\lambda \cdot \delta}{d x} \cdot L \cdot\left(T_{i}-T_{i+1}\right) \\
& +S_{i} \cdot L \cdot d x-U_{L} \cdot\left(T_{i}-T_{a m b}\right) \cdot L \cdot d x \\
& =\frac{m_{\text {fin }} \cdot c_{p, \text { fin }}}{d t} \cdot\left(T_{i}^{\text {new }}-T_{i}^{\text {old }}\right)
\end{aligned}
$$

$1<\mathrm{i}<\mathrm{n}:$

$\frac{\lambda \cdot \delta}{d x} \cdot L \cdot\left(T_{i}-T_{i-1}\right)-\frac{\lambda \cdot \delta}{d x} \cdot L \cdot\left(T_{i}-T_{i+1}\right)$

$+\mathrm{S}_{\mathrm{i}} \cdot \mathrm{L} \cdot \mathrm{dx}-\mathrm{U}_{\mathrm{L}} \cdot\left(\mathrm{T}_{\mathrm{i}}-\mathrm{T}_{\mathrm{amb}}\right) \cdot \mathrm{L} \cdot \mathrm{dx}$

$=\frac{\mathrm{m}_{\text {fin }} \cdot \mathrm{c}_{\mathrm{p}, \mathrm{fin}}}{\mathrm{dt}} \cdot\left(\mathrm{T}_{\mathrm{i}}^{\text {new }}-\mathrm{T}_{\mathrm{i}}^{\text {old }}\right)$

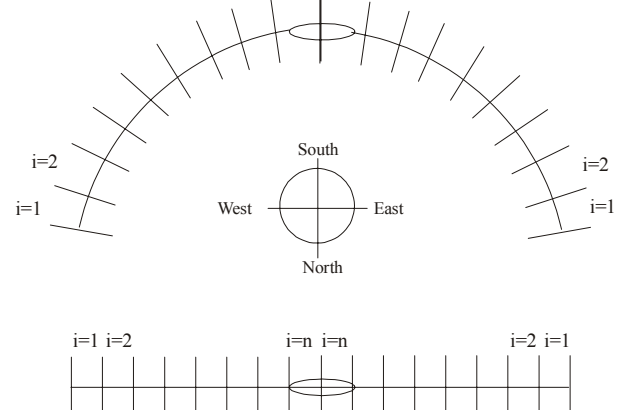

Fig. 8: The fins are discretized into a number of elements.

$\mathrm{i}=\mathrm{n}:$

$\frac{\lambda \cdot \delta}{d x} \cdot L \cdot\left(T_{i}-T_{i-1}\right)-U A_{\text {manifold }} \cdot\left(T_{i}-T_{\text {manifold }}\right)+S_{i} \cdot L \cdot d x-U_{L} \cdot\left(T_{i}-T_{\text {amb }}\right) \cdot L \cdot d x=\frac{m_{\text {fluid }} * c_{p, f l u i d *}}{d t} \cdot\left(T_{i}^{\text {new }}-T_{i}^{\text {old }}\right)$

Here, the solar radiation absorbed on the fin, $\mathrm{S}_{\mathrm{i}}$, is dependent on the position on the fin, due to varying incident angles (for curved fins) and due to possible shadows on the fin (for both flat and curved fins). The principles of determining the size and position on the fin of the shadows are described in [2]. 
The heat exchange capacity rate, $\mathrm{UA}_{\text {manifold, }}$, has a constant value larger than zero if $\mathrm{T}_{\mathrm{n}}$ is larger than the lowest evaporation temperature and if $T_{n}$ is larger than the mean temperature in the manifold pipe. In other cases, $\mathrm{UA}_{\text {manifold }}$ is zero.

\section{Solar radiation and view factors}

The total solar radiation absorbed on the fin, $\mathrm{S}_{\mathrm{i}}$, can be written as:

$\mathrm{S}_{\mathrm{i}}=\mathrm{S}_{\mathrm{i} \text {,dir,front }}+\mathrm{S}_{\mathrm{i} \text {,dir,back }}+\mathrm{S}_{\mathrm{i} \text {,dif,sky,front }}+\mathrm{S}_{\mathrm{i} \text {,dif, sky,back }}+\mathrm{S}_{\mathrm{i} \text {,dir,ground,front }}+\mathrm{S}_{\mathrm{i} \text {, dir,ground,back }}+\mathrm{S}_{\mathrm{i} \text {,dif, ground,front }}+\mathrm{S}_{\mathrm{i} \text {,dif,ground, back }}$

where,

$$
\begin{aligned}
& \mathrm{S}_{\mathrm{i} \text {,dir,front }}=(\tau \alpha)_{\mathrm{e}} \cdot \mathrm{G}_{\mathrm{b}} \cdot \mathrm{K}_{\theta} \cdot \mathrm{R}_{\mathrm{b} \text {,front }} \cdot \mathrm{R}_{\text {sun }} \\
& \mathrm{S}_{\mathrm{i} \text {,dir, back }}=(\tau \alpha)_{\mathrm{e}} \cdot \mathrm{G}_{\mathrm{b}} \cdot \mathrm{K}_{\theta} \cdot \mathrm{R}_{\mathrm{b}, \text { back }} \cdot \mathrm{R}_{\text {sun }} \\
& \mathrm{S}_{\mathrm{i}, \mathrm{dif}, \text { sky,front }}=(\tau \alpha)_{\mathrm{e}} \cdot \mathrm{G}_{\mathrm{d}} \cdot \mathrm{K}_{\theta, \mathrm{dif}} \cdot \mathrm{F}_{\text {col,sky,front }} \\
& \mathrm{S}_{\mathrm{i}, \text { dif, sky,back }}=(\tau \alpha)_{\mathrm{e}} \cdot \mathrm{G}_{\mathrm{d}} \cdot \mathrm{K}_{\theta, \text { dif }} \cdot \mathrm{F}_{\text {col,sky, back }} \\
& \mathrm{S}_{\mathrm{i}, \text { dir, ground,front }}=(\tau \alpha)_{\mathrm{e}} \cdot \mathrm{G}_{\mathrm{b}} \cdot \mathrm{K}_{\theta, \mathrm{gr}} \cdot \mathrm{F}_{\text {col,dir, ground,front }} \cdot \rho \\
& \mathrm{S}_{\mathrm{i}, \text { dir, ground,back }}=(\tau \alpha)_{\mathrm{e}} \cdot \mathrm{G}_{\mathrm{b}} \cdot \mathrm{K}_{\theta, \mathrm{gr}} \cdot \mathrm{F}_{\text {col,dir, ground, back }} \cdot \rho \\
& \mathrm{S}_{\mathrm{i} \text {,dif, ground,front }}=(\tau \alpha)_{\mathrm{e}} \cdot \mathrm{G}_{\mathrm{d}} \cdot \mathrm{F}_{\text {ground,sky }} \cdot \mathrm{K}_{\theta, \mathrm{gr}} \cdot \mathrm{F}_{\text {col,dif,ground,front }} \cdot \rho \\
& \mathrm{S}_{\mathrm{i}, \text { dif,ground,back }}=(\tau \alpha)_{\mathrm{e}} \cdot \mathrm{G}_{\mathrm{d}} \cdot \mathrm{F}_{\text {ground,sky }} \cdot \mathrm{K}_{\theta, \mathrm{gr}} \cdot \mathrm{F}_{\text {col,dif,ground, back }} \cdot \rho
\end{aligned}
$$

The incident angle modifier $\mathrm{K}_{\theta}$ is calculated by:

$$
\mathrm{K}_{\theta}=1-\tan ^{\mathrm{a}}\left(\frac{\theta}{2}\right)
$$

Here, the incident angle, $\theta$, is defined as the incident angle on the absorber. The incident angle modifiers for diffuse radiation, $\mathrm{K}_{\theta \text {,dif }}$, and ground reflected radiation, $\mathrm{K}_{\theta, \mathrm{gr}}$, are evaluated by equation (14) using $\theta=\pi / 3$ [3].

An illustration of the view factors is given in Fig. 9 and a more detailed description of the view factors including reduction of the view factors to ground and sky due to the collector rows, is given in [4].

\section{Numerical issues}

In order to evaluate the performance of the evacuated tubular collectors on an annual basis, the above theory is implemented into three TrnSys types; two TrnSys types for the two collector designs and an additional TrnSys type for the view factor calculations. Concerning the two collector types, for each simulation time step the equations (1)-(8) are solved through an iteration loop. The iteration is stopped when the fin temperature difference from iteration to iteration is less than $0.00001 \mathrm{~K}$ and when the difference from iteration to iteration in power from the manifold is less than $0.01 \mathrm{~W}$. 
If the criteria are not reached the iteration loop stops after 100,000 iterations, and a warning is written to an output file. This seldom happens and the influence on the final result is insignificant. The fins are discretized into nine elements (18 elements in total), and a typical annual simulation of a collector array takes approximately $3 \mathrm{~min}$. on a $2.8 \mathrm{GHz}$ PC when a timestep of $0.05 \mathrm{~h}$ is used.

\section{Parameter variations}

In this section, it is illustrated how the model can be used for geometrical parameter studies. In the following examples it is assumed that the ground mounted evacuated tubular collector panels are operating in a solar heating plant at a constant operating temperature of $50^{\circ} \mathrm{C}$ in the heat exchanger manifold pipe throughout the year. The model data of the collector panel is given in Table 1. The collector performance is investigated for Uummannaq, Greenland, as summarized in Table 2. The albedo is set higher during a large part of the year due to snow on the ground.

Table 1: Data describing the collector in the model.

\begin{tabular}{|l|c|c|}
\hline Tube length, $\mathrm{L}$ & {$[\mathrm{m}]$} & 2 \\
\hline Glass tube radius, $\mathrm{r}_{\mathrm{c}}$ & {$[\mathrm{m}]$} & 0.05 \\
\hline Absorber radius for curved fin, $\mathrm{r}_{\mathrm{p}}$ & {$[\mathrm{m}]$} & 0.04375 \\
\hline Fin width for curved fin, $\mathrm{w}_{\mathrm{c}}$ (corresponding to a curved fin angle of $\left.164^{\circ}\right)$ & {$[\mathrm{m}]$} & 0.125 \\
\hline Fin width $\left(\right.$ for flat fin), $\mathrm{w}_{\mathrm{f}}$ & {$[\mathrm{m}]$} & 0.0875 \\
\hline Fin thickness & {$[\mathrm{m}]$} & 0.0002 \\
\hline Fin conductivity, $\mathrm{k}_{\text {fin }}$ & {$[\mathrm{W} / \mathrm{mK}]$} & 216 \\
\hline Tube centre distance, $\mathrm{C}$ & {$[\mathrm{m}]$} & 0.125 \\
\hline Tube heat loss coefficient, $\mathrm{k}_{\text {tube }}$ based on absorber front side area & {$\left[\mathrm{W} / \mathrm{m}^{2} \mathrm{~K}\right]$} & 2.43 \\
\hline Effective transmittance absorbtance product, $(\tau \alpha)_{\mathrm{e}}$ & {$[-]$} & 0.84 \\
\hline Incident angle modifier constant, a & {$[-]$} & 3.8 \\
\hline Manifold heat loss coefficient, $\mathrm{k}_{\text {manifold }}$ & {$[\mathrm{W} / \mathrm{K} / \mathrm{m}]$} & 0.134 \\
\hline Manifold heat exchange rate per connection, $\mathrm{UA}_{\text {manifold }}$ & {$[\mathrm{W} / \mathrm{K}]$} & 10 \\
\hline Operating temperature in manifold & {$\left[{ }^{\circ} \mathrm{C}\right]$} & 50 \\
\hline Collector heat capacity, $\mathrm{C}_{\text {collector }}$ & {$[\mathrm{kJ} / \mathrm{K} / \mathrm{tube}]$} & 1.9 \\
\hline Distance between collector rows & {$[\mathrm{m}]$} & 10 \\
\hline
\end{tabular}

Table 2: Summarized data for Uummannaq, Greenland.

\begin{tabular}{|c|c|c|}
\hline Location & Unit & Uummannaq, GL [5] \\
\hline Latitue. & {$\left[{ }^{\circ}\right]$} & 71 \\
\hline Longitude & {$\left[{ }^{\circ}\right]$} & -4.2 \\
\hline $\mathrm{T}_{\text {a,average }}$ & {$\left[{ }^{\circ} \mathrm{C}\right]$} & 888 \\
\hline $\mathrm{G}_{\text {global }}$ & {$\left[\mathrm{kWh} / \mathrm{m}^{2}\right]$} & 409 \\
\hline $\mathrm{G}_{\text {diffuse }}$ & {$\left[\mathrm{kWh} / \mathrm{m}^{2}\right]$} & $0.2(15 / 6-14 / 9)$ or $0.7(15 / 9-14 / 6)$ \\
\hline Albedo & {$[-]$} & 0 \\
\hline
\end{tabular}

Fig. 9: An illustration, based on three collector rows, of the view factors used in the model. $\mathbf{R}_{\text {sun }}$ includes the effect of one row shadowing the next row.
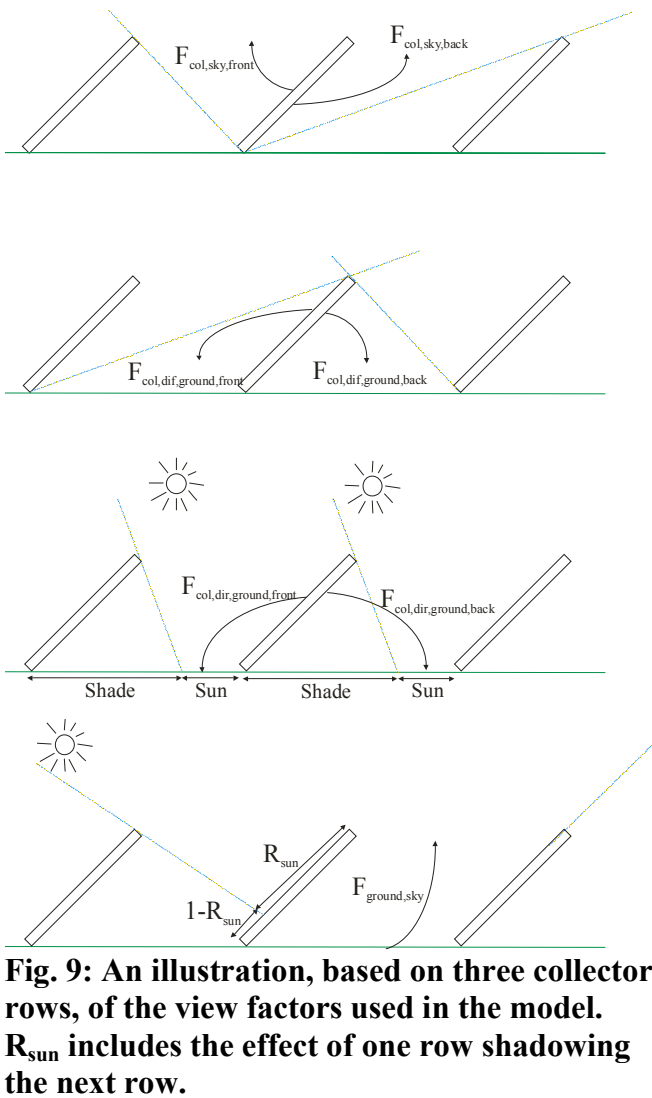


\section{View Factors}

To get an understanding of the geometry included in the models, illustrations of some of the view factors for different conditions is given below. The view factors are calculated for a collector tilt of $60^{\circ}$ and for infinite distance between the collector rows. For different tube centre distances Fig. 10 and Fig. 11 shows the view factor from one tube to the two neighbour tubes, $F_{\text {tube,tube, and the }}$ view factors to the sky and ground from the collec

For the collector front side, it can be seen that the flat fin collector has a larger view factor to the sky, a smaller view factor to the ground and a smaller view factor between the tubes compared to the curved fin collector. This is because parts of the curved fin - due to the curve - face the neighbour tubes and the ground more than the flat fin. Further, as expected, the view factors between the tubes decreases with increasing tube centre distances.

For the collector back side, it can be seen that there is almost no difference between the curved and the flat fin. Here the reason is that, when calculating the view factors, the back side of the curved fin can be treated as a flat fin placed in the opening of the curved fin.

Fig. 12 shows the yearly diffuse sky and ground reflected radiation absorbed by the fin per $\mathrm{m}^{2}$ front side absorber.

For the collector back side, it can be seen that, just as for the view factors, there is almost no differences between the curved and the flat fin. For the collector front side it is clear that the flat fin absorbs more diffuse radiation than the curved fin.

Finally, Fig. 13 shows the direct radiation absorbed by the front side of the fins. As expected, due to the view factors between fins and sky, the flat fin absorbs more direct radiation per $\mathrm{m}^{2}$ front side absorber on a yearly basis. As it looks like the flat fin collector is more efficient, it must be pointed out that the absorbed energy quantities are given per $\mathrm{m}^{2}$ absorber area and that the curved fin absorber area is $45 \%$ larger than the flat fin absorber area.

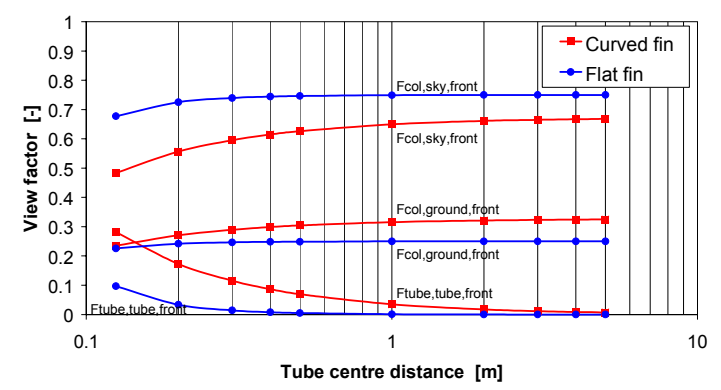

Fig. 10: View factors for the collector front side.

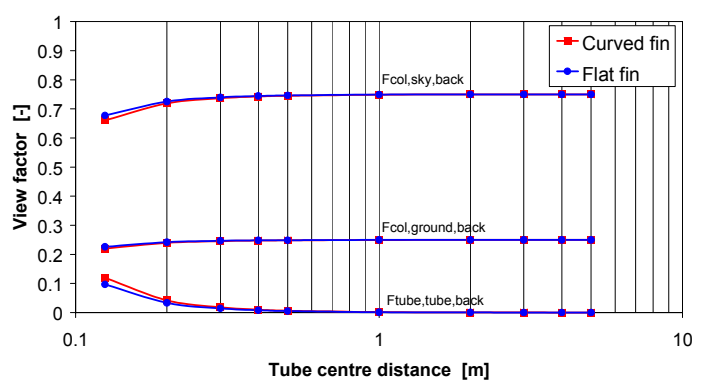

Fig. 11: View factors for the collector back side.

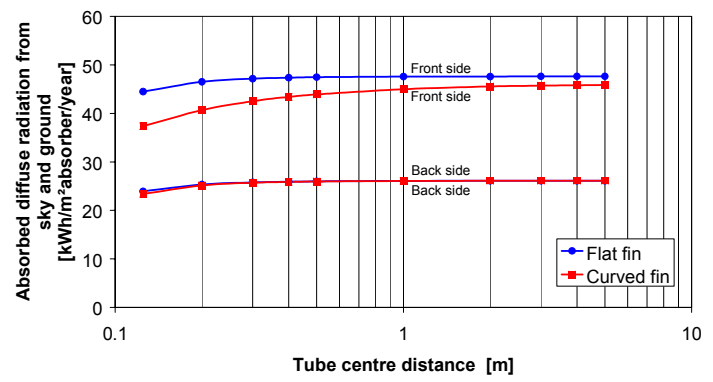

Fig. 12: Absorbed diffuse sky and ground reflected radiation.

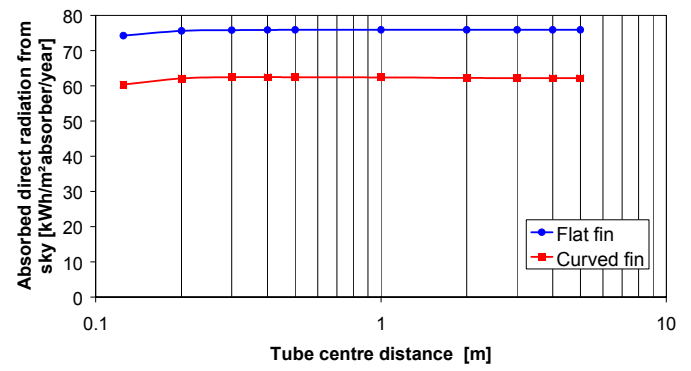

Fig. 13: Absorbed direct radiation. 


\section{Temperature profiles on the fin}

Before going into thermal performance analyses, some examples of the temperature distribution on the fins are given. For a summer day (31/7), Fig. 14 and Fig. 15 show the temperature profile at solar time $9 \mathrm{AM}$, 12 PM and 3 PM for the curved and the flat fin respectively. At these three times there are no shadows from the neighbour tubes. The temperature distribution on the curved fin is symmetrical around the heat pipe at 12 PM whereas the east side of the fin is warmer during the morning and the west side of the fin is warmer during the afternoon.

This clearly illustrates the influence of the distribution of the solar radiation on the fin and it explains why the traditional fin efficiency, F, cannot be applied when analysing this type of collector in detail. As expected for the flat fin, there is symmetry in the temperature distribution at all three times. The differences in the temperature level for the three times are due to the weather conditions.

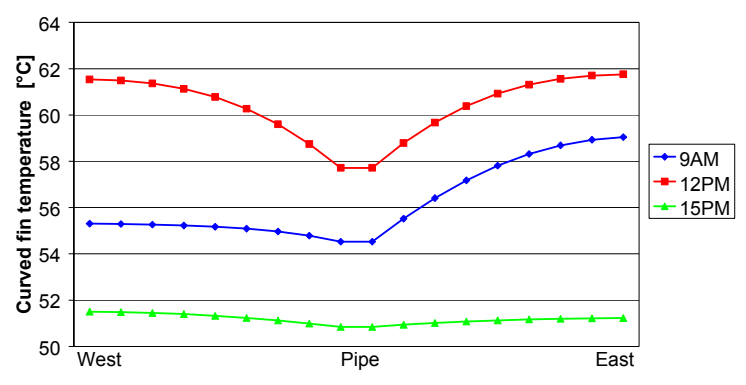

Fig. 14: The temperature distribution on the curved fin in the morning, at noon and in the afternoon of a summer day.

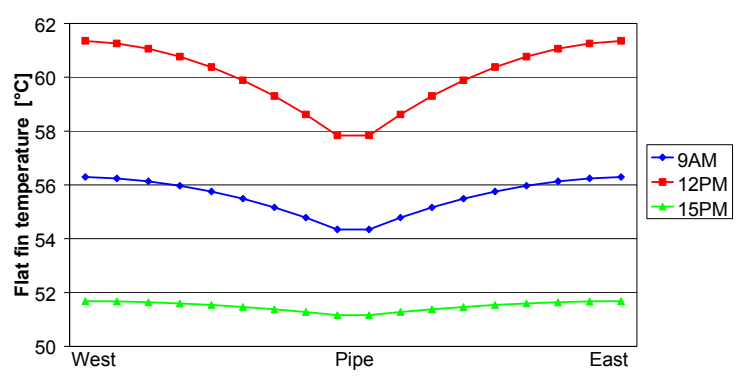

Fig. 15: The temperature distribution on the flat fin in the morning, at noon and in the afternoon of a summer day.

\section{Collector tilt}

Fig. 16 shows the thermal performance per tube as a function of the collector tilt. The figure shows that the optimum tilt is about $45^{\circ}$ for the flat fin collector and slightly higher for the curved fin collector. The reason is most likely related to the differences in the view factors for the two collectors. As the curved fin collector, due to the design, sees more of the ground compared to the flat fin collector, the curved fin collector can utilize the ground reflected

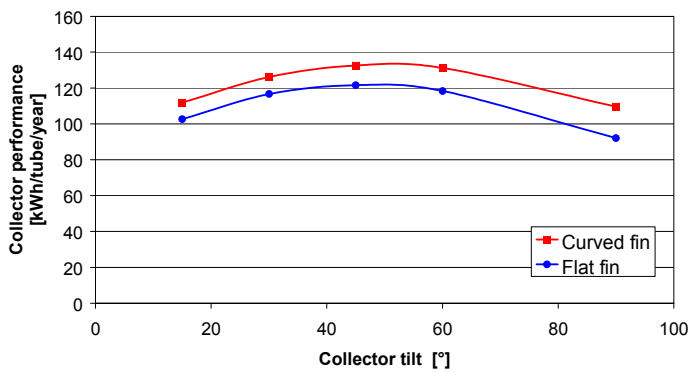

Fig. 16: The thermal performance per tube as a function of the collector tilt. radiation better than the flat fin collector and consequently the optimum tilt is larger for the curved fin collector than for the flat fin collector. The curved fin collector performs better than the flat fin collector as the curved fin absorber area is larger than the flat fin absorber area.

\section{Operating temperature}

Fig. 17 shows the thermal performance as a function of the operating temperature in the manifold tube. 
As expected the thermal performance decreases with increasing temperature level due to the increasing heat loss. Further, it can be seen that the curves are about to cross at a temperature of $90^{\circ} \mathrm{C}$. The reason is that the heat loss is larger for the curved fin collector compared to the flat fin collector as the heat loss coefficient (the same for the two collectors) is based on the absorber front side area and the curved absorber is larger than the flat fin absorber.

\section{Tube centre distances}

Fig. 18 shows the thermal performance per tube as a function of the tube centre distance. The thermal performance increases for increasing tube centre distances up to about $0.3 \mathrm{~m}$, due to reduced shaded areas, reduced view factors between the tubes and thus increased view factors to sky and ground. For even larger distances the utilized energy decreases again, due to the increasing heat loss from the manifold pipes.

\section{Collector rows distances}

Finally, Fig. 19 shows the thermal performance per tube as a function of the distance between the collector rows. It can be seen that thermal performance increases rapidly when the row distance increases from $1 \mathrm{~m}$ to $10 \mathrm{~m}$. Further increase in the row distance has less impact on the thermal performance. The reason for the increase in thermal performance is that with increasing distances the shadows from neighbour rows on the collector (see Fig. 9 bottom) decreases and the view factor from the collector to ground and sky increases. It must be noticed that the heat loss in the pipes connecting the collector rows is not included in this analysis.

\section{Summary}

Two designs of ground mounted heat pipe evacuated tubular collectors operating in a solar heating plant are investigated theoretically. The absorber fins inside the evacuated tubes are either flat or curved and the surfaces of the fins have selective coating on both sides. Two new TrnSys models for evacuated tubular collectors are developed. The models calculate in detail the heat transfer processes of the absorber fins.

It is illustrated how the model can be used for geometrical parameter studies. For example, it is investigated how fin geometry, collector tilt, operating temperature, tube distances and distances between collector rows influences the yearly thermal collector performance. 
RESEARCH EXAMPLE 2: ALL GLASS EVACUATED TUBULAR COLLECTORS

All-glass evacuated tubular collectors are based on double glass tubes where the outside of the inner glass wall is treated with an absorbing selective coating and the evacuated space is between the tubes as illustrated in Fig. 20.

A collector design based on horizontal tubes connected to a manifold pipe is especially popular due to its low cost. An illustration of the collector design is shown in Fig. 21.

The collector fluid enters the bottom of the square manifold channel and leaves at the top of the manifold channel. The intended flow inside the glass tubes is indicated with

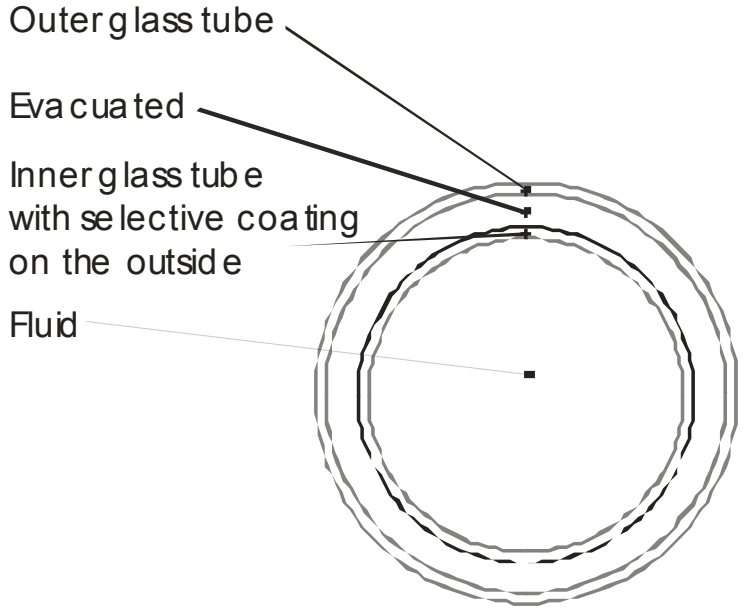

Fig. 20: Design of an All-glass evacuated tube. the arrows. The flow is primarily naturally driven, as the walls of the tubes are hot due to the solar radiation. However it is unclear, how the operating conditions and the collector geometry influence the flow structures in the tubes and thus the collector performance.

The objective of this work is to investigate the heat transfer and the flow structures inside the tubes for different flow rates and collector geometries by means of Computational Fluid Dynamics (CFD).

\section{Numerical investigations}

To solve the flow and energy equations in the glass tubes, a simulation model of the flow in the tubes is developed using the CFD code Fluent 6.1 [6]. As illustrated in Fig. 22, only one section of the collector with two horizontal tubes placed in a vertical plane is investigated.

Steady state numerical solutions are obtained for laminar flow with the Boussinesq approximation for buoyancy modelling. The velocity-pressure coupling is treated by using the SIMPLE algorithm and the First Order Upwind scheme is used for the momentum and energy terms.

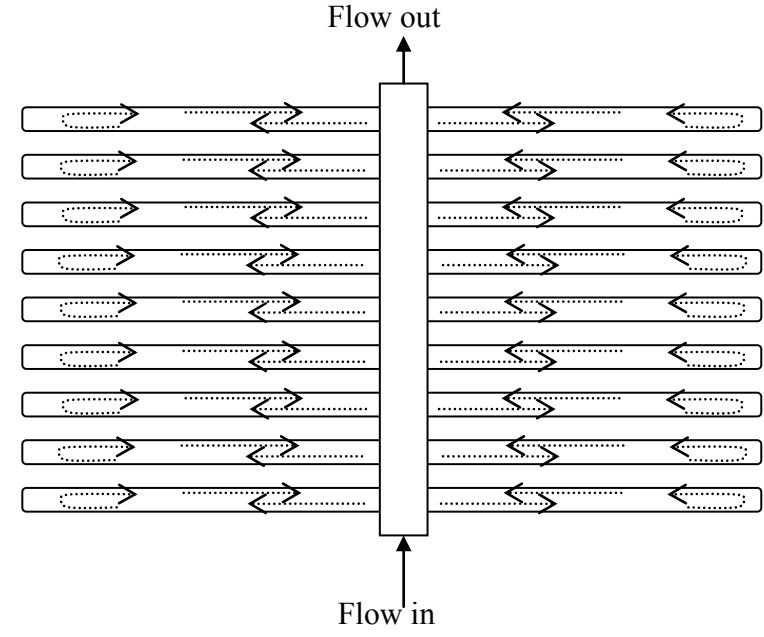

Fig. 21: Illustration of an All-glass evacuated tubular collector with horizontal tubes.

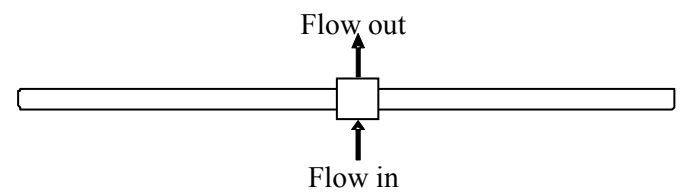

Fig. 22: One section of the collector with two horizontal tubes is investigated.

\section{Geometry}

The model consists of the inner boundaries of the geometry. The outer glass tube, the evacuated space between the two glass tubes and the wall thickness of the inner glass tube are not included in the model. Also the outer casing and the insulation material of the manifold channel are not included in the model. This means that no solids are simulated - only the fluid 
is included in the model. The conduction in the inner glass wall is however included in the model. The geometry is summarized in Table 3.

TABLE 3: GEOMETRY OF THE

The computational mesh is constructed in NUMERICAL MODELS.

the pre-processing program Gambit 2.0.4

[7]. The number of computational cells depends on the length of the tubes and is given in Table 3.

Fig. 23 shows a close up of the mesh near the manifold channel.

\section{Boundary conditions}

The solar irradiance is simulated as a distributed heat flux on the tube wall. The flux varies from $0 \mathrm{~W} / \mathrm{m}^{2}$ to $1150 \mathrm{~W} / \mathrm{m}^{2}$ as shown in Fig. 24. The average flux on the tube wall is $566 \mathrm{~W} / \mathrm{m}^{2}$.

The heat loss from the tubes is modelled with a heat loss coefficient of $0.85 \mathrm{~W} / \mathrm{m}^{2} \mathrm{~K}$ [8] and a constant ambient temperature of $293 \mathrm{~K}$. The heat loss coefficient is related to the absorber area. The manifold channel is assumed to have zero heat loss.

\begin{tabular}{|l|l|}
\hline $\begin{array}{l}\text { Side length of } \\
\text { manifold channel: }\end{array}$ & $0.06 \mathrm{~m}$ \\
\hline $\begin{array}{l}\text { Glass tube inner } \\
\text { diameter: }\end{array}$ & $0.037 \mathrm{~m}$ \\
\hline $\begin{array}{l}\text { Glass tube outer } \\
\text { diameter (used in } \\
\text { manifold channel): }\end{array}$ & $0.047 \mathrm{~m}$ \\
\hline $\begin{array}{l}\text { Length of glass tube } \\
\text { exposed to solar } \\
\text { radiation: }\end{array}$ & $0.59 \mathrm{~m}$ \\
\hline $\begin{array}{l}\text { Number of } \\
\text { computational cells: }\end{array}$ & $\begin{array}{l}1.17 \mathrm{~m} \\
1.47 \mathrm{~m}\end{array}$ \\
\hline $\begin{array}{l}\text { Illustration of } \\
\text { geometry: }\end{array}$ & 948682 \\
\hline
\end{tabular}

Five different inlet mass flow rates of respectively $0.05 \mathrm{~kg} / \mathrm{min}, 0.4 \mathrm{~kg} / \mathrm{min}, 1$ $\mathrm{kg} / \mathrm{min}, 3 \mathrm{~kg} / \mathrm{min}$ and $10 \mathrm{~kg} / \mathrm{min}$ have been computed.

The inlet velocity profile has been found by first making a computation with a uniform inlet velocity profile. The outlet velocity profile from this simulation has then been used as the inlet velocity profile for the final

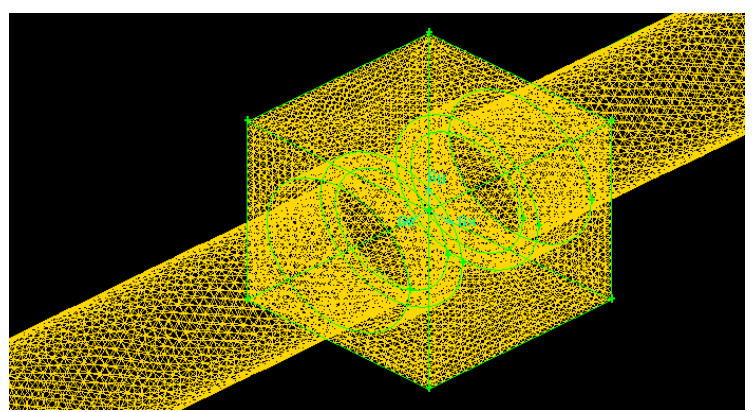

Fig. 23: The mesh near the square manifold channel. simulation.

The inlet temperature has been $333 \mathrm{~K}$ during all computations. A $40 \%$ propylene-glycol/water mixture has been used as working fluid.

\section{Results}

The presented results will include illustrations of flow patterns in the vertical centre plane of the model near the manifold channel and in the manifold outlet plane. Further, some overall analyses of the "collector" performance as a function of tube lengths and mass flow rates will be presented.

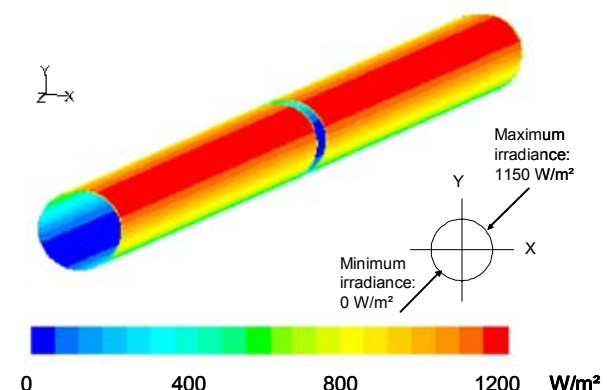

Fig. 24: Distribution of the heat flux on the inner glass tubes. 


\section{Flow distribution}

For a tube length of $1.17 \mathrm{~m}$, the left column in Fig. 25 shows velocity vectors in the vertical tube centre plane near the manifold channel for the five investigated inlet mass flow rates.

At the smallest mass flow rate (top-left picture) it can be seen how the fluid flows directly from the inlet in the manifold channel out in the two horizontal tubes. The fluid returns to the manifold channel along the top of the tubes. The two flows from the two tubes exits at the outlet with a profile, which is clearly formed by the flows in the tubes.

The flow patterns for the next two flow rates look similar to the flow pattern for the lowest flow rate; however, there is one significant difference. Due to the larger inlet velocities, the flow rises higher in the manifold channel before it, due to buoyancy forces, turns down to the tube bottom wall and flows out in the tubes. The differences in the forced- and buoyancy driven flows are evident just by seeing how far up in the manifold tube the flow rises.

For the two highest flow rates it is clear that some of the flow passes directly through the manifold channel without entering the tubes. Therefore, the outlet velocity profiles look different for the highest flow rates compared to the outlet velocity profiles for the lowest flow rates.

The right column in Fig. 25 shows the velocity contours in the outlet plane. It can be seen how the velocity pattern changes from being dominated by the two flows from the tubes for the lowest inlet flow rates to, for the highest flow rates, being dominated mainly by the inlet flow.

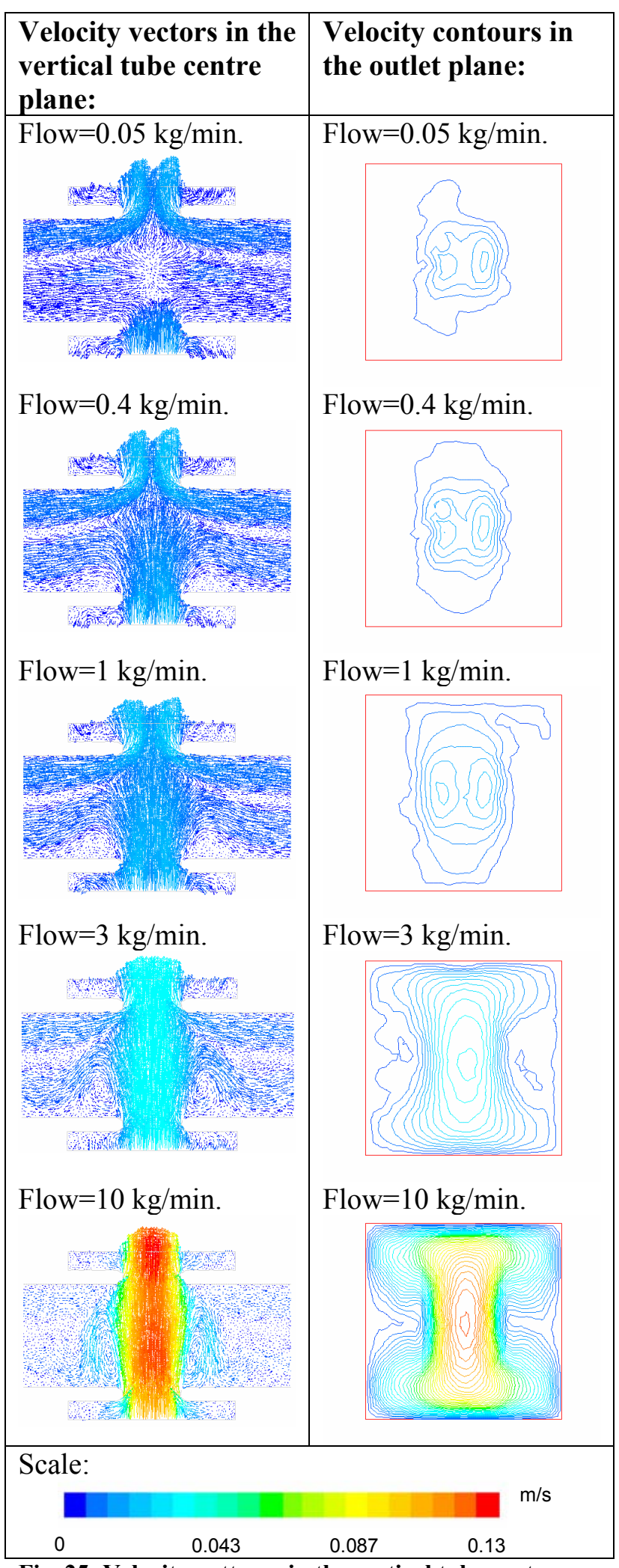

Fig. 25: Velocity patterns in the vertical tube centre plane (left column) and in the outlet plane (right column). Tube length: $\mathrm{L}=1.17 \mathrm{~m}$. 


\section{Thermal performance}

The thermal performance is investigated by calculating efficiencies for the different combinations of flow rates and tube lengths. The efficiency, $\eta$, is defined as the ratio between the power out of the collector, $\mathrm{P}_{\text {collector, }}$ and the distributed heat flux absorbed by the collector, $\mathrm{P}_{\text {solar: }}$ :

$\eta=\frac{P_{\text {collector }}}{P_{\text {solar }}}$

Notice that this efficiency cannot be compared with the traditional way of defining the collector efficiency as optical losses are not included in the efficiency used here.

Fig. 26 shows the efficiency as a function of the mass flow rate. The efficiency is highest for flow rates around $0.4 \mathrm{~kg} / \mathrm{min}-1 \mathrm{~kg} / \mathrm{min}$. The explanation for this result can be found in Fig. 27, which shows the mean temperature in the collector as a function of the mass flow rate. For the largest inlet flow rates $(3 \mathrm{~kg} / \mathrm{min}-10 \mathrm{~kg} / \mathrm{min})$ a large part of the fluid flows directly through the manifold channel leaving only a smaller part flowing out in the tubes. Therefore, the average temperature in the whole collector rises.

This leads to a higher heat loss and thus a lower efficiency. For the lowest flow rate $(0.05 \mathrm{~kg} / \mathrm{min})$ almost all the inlet flow goes out in the tubes, but now the flow is so small that this alone leads to an increased average temperature in the whole collector.

That the efficiency in fact decreases with increasing average temperatures in the whole collector is very clear in Fig. 28 Here each dot represents an efficiency found at a given inlet flow rate.

All the dots together form an almost straight line with a tilt that shows how the efficiency decreases with increasing heat loss caused by increasing average temperatures in the whole collector. The collector with the shortest tube has the highest efficiency and vice versa.

Finally, Fig. 29 shows the efficiency as a function of the average of the inlet- and outlet temperature. As in Fig. 26 and in Fig. 28 it can be seen that the highest efficiency is

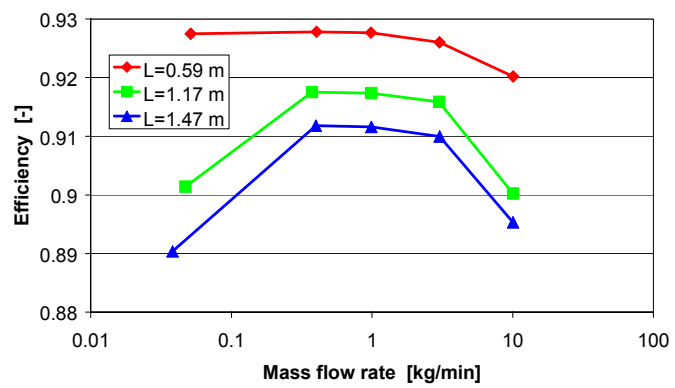

Fig. 26: The efficiency as a function of the mass flow rate.

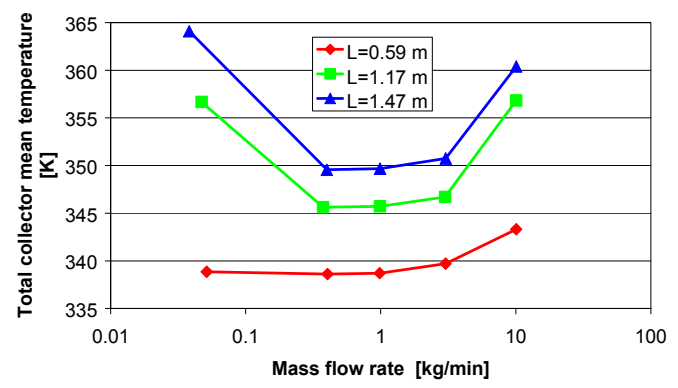

Fig. 27: The mean temperature in the total collector as a function of the mass flow rate.

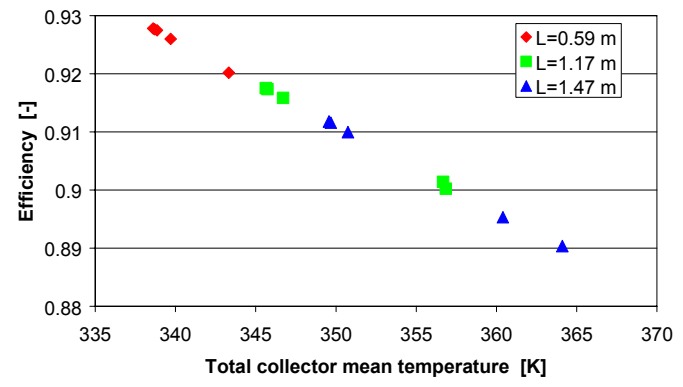

Fig. 28: The efficiency as a function of mean temperature in the whole collector. achieved for the shortest tube length.

The results further show that the inlet mass flow rate has a relatively small influence (1-2\%) on the resulting efficiencies. This might seem strange considering the large differences in the flow patterns near the manifold channel (Fig. 25). 
The main reason is that the flow in the tubes at a distance from the manifold channel is relatively unaffected by the inlet flow.

For a tube length of $\mathrm{L}=1.17 \mathrm{~m}$, Fig. 30 shows the maximum velocity magnitude as a function of the distance from the manifold centre. For the varying inlet flows, the figure shows that close to the manifold channel there are differences in the maximum velocity magnitude but further out in the tubes there are almost no differences in the max This explains why the absolute differences in the collector efficiencies are so small for the varying inlet flow conditions.

Fig. 30 also shows that the flows out in the tubes are:

- largest for an inlet flow of $0.4 \mathrm{~kg} / \mathrm{min}$

- $2^{\text {nd }}$ largest for an inlet flow of $1 \mathrm{~kg} / \mathrm{min}$

- $\quad 3^{\text {rd }}$ largest for an inlet flow of $3 \mathrm{~kg} / \mathrm{min}$

- $2^{\text {nd }}$ smallest for an inlet flow of 0.05 $\mathrm{kg} / \mathrm{min}$ and

- smallest for an inlet flow of $10 \mathrm{~kg} / \mathrm{min}$

This corresponds nicely with the results presented in Fig. 26 where the order of efficiencies is the same.

Finally, it should be mentioned that another reason for the small differences in the calculated efficiencies is that the heat loss coefficient for the tubes is very small. Due this low heat loss coefficient, the differences in the mean temperature in the whole collector have an only minor influence on the final efficiency.

\section{Summary}

Heat transfer and flow structures inside All-glass evacuated tubular collectors for different operating conditions are investigated by means of Computational Fluid Dynamics (CFD). The investigations are based on a collector design with horizontal tubes connected to a vertical manifold channel.

Three different tube lengths varying from $0.59 \mathrm{~m}$ to $1.47 \mathrm{~m}$ have been modelled with five different inlet mass flow rates varying from $0.05 \mathrm{~kg} / \mathrm{min}$ to $10 \mathrm{~kg} / \mathrm{min}$ with a constant inlet temperature of $333 \mathrm{~K}$. Under these operating conditions the results showed that:

- the collector with the shortest tube length achieved the highest efficiency

- the optimal inlet flow rate was around $0.4-1 \mathrm{~kg} / \mathrm{min}$

- the flow structures in the glass tubes were relatively uninfluenced by the inlet flow rate Generally, the results showed only small variations in the efficiencies. This indicates that the collector design is well working for most operating conditions.

\section{CONCLUSION AND OUTLOOK}

In this paper two research examples on evacuated tubular collectors are given. The first example concerns development of theoretical models for Heat pipe evacuated tubular collectors. In the second example heat transfer and flow structures inside All-glass evacuated 
tubular collectors for different operating conditions are investigated by means of Computational Fluid Dynamics (CFD).

For the heat pipe investigations, ground mounted Heat pipe evacuated tubular collectors operating in a solar heating plant are investigated theoretically. It is illustrated how the developed model can be used for geometrical parameter studies. For example, it is investigated how fin geometry, collector tilt, operating temperature, tube distances and distances between collector rows influences the yearly thermal collector performance.

The All-glass investigations were based on a collector design with horizontal tubes connected to a vertical manifold channel. With different glass tube lengths and for varying flow rates it was shown that the collector with the shortest tube length achieved the highest efficiency and the optimal inlet flow rate was around $0.4-1 \mathrm{~kg} / \mathrm{min}$. However, generally the All-glass results showed only small variations in the efficiencies. This indicates that the collector design is well working for most operating conditions.

Further work:

Parallel to the theoretical work, the investigated Heat pipe and All-glass evacuated tubular collectors will be tested side-by-side in an outdoor test facility. Among other things, the measured performances will be used to a final validation of the theoretical models and the thermal performance of differently designed evacuated tubular collectors will be compared. Based on the findings and on economy considerations, optimum designed evacuated tubular collectors for Arctic latitudes will be recommended.

\section{ACKNOWLEDGEMENTS}

This study is financed by the VILLUM KANN RASMUSSEN FOUNDATION.

\section{REFERENCES}

[1] Klein, S.A. et al., "TRNSYS 14.2", University of Wisconsin Solar Energy Laboratory, 1996.

[2] Shah, L.J., Furbo, S., "Modelling Shadows on Evacuated Tubular Collectors with Cylindrical Absorbers", Journal of Solar Energy Engineering, Transactions of the ASME, 2005 (In press).

[3] Gordon J. (ed.). Solar Energy. The State of the Art. ISES Position papers. James \& James, London. ISBN: 1-902916-23-9, (2001).

[4] Shah, L.J., Furbo, S., "Utilization of Solar Radiation at High Latitudes with Evacuated Tubular Collectors" NorthSun 2005, Proceedings, In press.

[5] Kragh J. et al. "Grønlandske vejrdata. Nuuk. Uummannaq" Department of Civil Engineering, Technical University of Denmark, Nov. 2002.

[6] Fluent 6.1 User's Guide (2003). Fluent Inc. Centerra Resource Park 10 Cavendish Court Lebanon, NH 03766

[7] Gambit 2 User's Guide (2001). Fluent Inc. Centerra Resource Park 10 Cavendish Court Lebanon, NH 03766

[8] Qin 1. and Furbo S. (1999) Vakuumrørsolfangere fra Kina. Report R-032. Department of Buildings and Energy, Technical University of Denmark. 


\section{NOMENCLATURE}

$\mathrm{C}$

$\mathrm{C}_{\text {collector }}$

$\mathrm{c}_{\mathrm{p}, \text { fin }}$

$\mathrm{c}_{\mathrm{p}, \text { fluid* }}$

$\mathrm{dQ}_{\text {manifold }}$

dt

$\mathrm{dx} \quad$ Width of discretization element, $\mathrm{m}$

$\mathrm{F}_{\text {col,dif,ground,back }} \mathrm{View}$ factor from the collector back

$\mathrm{F}_{\text {col,dif,ground,front }} \mathrm{View}$ factor from the collector

$\mathrm{F}_{\text {col,dir,ground,back }} \mathrm{View}$ factor from the collector back

$\mathrm{F}_{\text {col,dir,ground,front }} \mathrm{View}$ factor from the collector

$\mathrm{F}_{\text {col,sky,back }} \quad$ View factor from the collector back

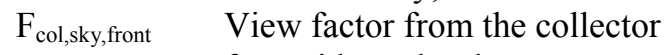

$\mathrm{F}_{\text {ground,sky }} \quad$ View factor the ground to the sky, -

$F_{\text {tube,tube }} \quad$ View factor from one tube to the

$\mathrm{G}_{\mathrm{b}}$

$\mathrm{G}_{\mathrm{d}}$

$\mathrm{G}_{\text {diffuse }}$

$\mathrm{G}_{\text {global }}$

$\mathrm{K}_{\theta}$

$\mathrm{K}_{\theta \text {,dif }}$

$\mathrm{K}_{\theta, \mathrm{gr}}$

L

$\mathrm{m}_{\text {fin }}$

m $_{\text {fluid* }}$

$\mathrm{P}_{\text {ETC }}$

$\mathrm{P}_{\text {loss }}$

$\mathrm{P}_{\underline{\mathrm{u}}}$

$\mathrm{P}_{\text {collector }}$

$\mathrm{P}_{\text {solar }}$

$\mathrm{R}_{\mathrm{b} \text {,back }}$ side to the part of the ground with diffuse solar radiation, front side to the part of the ground with diffuse solar radiation, side to the part of the ground with direct solar radiation,front side to the part of the ground with direct solar radiation,side to the sky, front side to the sky, neighbour tubes, -

Beam radiation on horizontal, $\mathrm{W} / \mathrm{m}^{2}$

Diffuse radiation on horizontal, $\mathrm{W} / \mathrm{m}^{2}$

Yearly diffuse radiation on horizontal, $\mathrm{kWh} / \mathrm{m}^{2}$

Yearly global radiation, $\mathrm{kWh} / \mathrm{m}^{2}$

Incident angle modifier for direct radiation, -

Incident angle modifier for diffuse radiation, -

Incident angle modifier for ground reflected radiation, -

Tube length, $\mathrm{m}$

Mass of discretized fin element, $\mathrm{kg}$

Average mass of fin material and

working fluid in heat pipe, $\mathrm{kg}$

Power from heat pipes, $\mathrm{W}$

Heat loss from manifold pipe, $\mathrm{W}$

Power from collector, $\mathrm{W}$

Power from collector, W

Solar radiation absorbed by

absorber, W

Geometric factor, -
$\mathrm{R}_{\mathrm{b} \text {,fron }}$

$r_{c}$

$r_{p}$

$\mathrm{R}_{\text {sun }}$

$\mathrm{S}_{\mathrm{i}}$

$\mathrm{S}_{\mathrm{i}, \mathrm{dif}, \text { sky,front }}$

$\mathrm{S}_{\mathrm{i}, \mathrm{dif}, \text { ground,back }}$

$\mathrm{S}_{\mathrm{i}, \text { dif, ground,front }}$

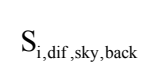

, sky, back

$\mathrm{S}_{\mathrm{i}, \mathrm{dir}, \text { back }}$

$\mathrm{S}_{\mathrm{i} \text {,dir,front }}$

$\mathrm{S}_{\mathrm{i}, \text { dir,ground,front }}$

Geometric factor, -

Glass tube radius, $\mathrm{m}$

Absorber radius for curved fin, $\mathrm{m}$

Part of tube irradiated by direct

radiation due to row shadows, -

Solar radiation absorbed on

element i, $\mathrm{W} / \mathrm{m}^{2}$

Diffuse sky radiation absorbed on

the absorber front side, $\mathrm{W} / \mathrm{m}^{2}$

Ground reflected diffuse radiation

absorbed on the absorber back side,

$\mathrm{W} / \mathrm{m}^{2}$

Ground reflected diffuse radiation

absorbed on the absorber front

side, $\mathrm{W} / \mathrm{m}^{2}$

Diffuse sky radiation absorbed on

the absorber back side, $\mathrm{W} / \mathrm{m}^{2}$

Direct radiation absorbed on the

absorber back side, $\mathrm{W} / \mathrm{m}^{2}$

Direct radiation absorbed on the

absorber front side, $\mathrm{W} / \mathrm{m}^{2}$

Ground reflected direct radiation

absorbed on the absorber front

side, $\mathrm{W} / \mathrm{m}^{2}$

$\mathrm{S}_{\mathrm{i}, \text { dir,ground,back }} \quad$ Ground reflected direct radiation

absorbed on the absorber front

side, $\mathrm{W} / \mathrm{m}^{2}$

$\mathrm{T}_{\mathrm{a} \text {,average } \quad \text { Yearly average ambient }}$

temperature, ${ }^{\circ} \mathrm{C}$

$\mathrm{T}_{\mathrm{amb}}$

$\mathrm{T}_{\mathrm{amb}}$

$\mathrm{T}_{\text {heatpipe }}$

$\mathrm{T}_{\mathrm{i}}$

$\mathrm{T}_{\mathrm{i}+1}$

$\mathrm{T}_{\mathrm{i}-1}$

$\mathrm{T}_{\mathrm{i}}^{\text {new }}$

$\mathrm{T}_{\mathrm{i}}^{\text {old }}$

$\mathrm{T}_{\text {manifold }}$

$\mathrm{T}_{\text {manifold,inlet }}$

$\mathrm{T}_{\text {manifold,outlet }}$

$\mathrm{UA}_{\text {manifold }}$

$\mathrm{U}_{\mathrm{L}}$

$\mathrm{U}_{\text {loss }}$

$\mathrm{W}_{\mathrm{c}}$

$\mathrm{W}_{\mathrm{f}}$

$\delta$

$\lambda$

$\rho$

$(\tau \alpha) \mathrm{e}$
Ambient temperature, ${ }^{\circ} \mathrm{C}$

Ambient temperature, ${ }^{\circ} \mathrm{C}$

Temperature of the heat pipe working fluid, ${ }^{\circ} \mathrm{C}$

Temperature of element $\mathrm{i},{ }^{\circ} \mathrm{C}$

Temperature of element $\mathrm{i}+1,{ }^{\circ} \mathrm{C}$

Temperature of element $\mathrm{i}-1,{ }^{\circ} \mathrm{C}$

New temperature of element $\mathrm{i},{ }^{\circ} \mathrm{C}$

Old temperature of element $\mathrm{i},{ }^{\circ} \mathrm{C}$

Mean temperature in manifold, ${ }^{\circ} \mathrm{C}$

Inlet temperature to manifold, ${ }^{\circ} \mathrm{C}$

Outlet temp. from manifold, ${ }^{\circ} \mathrm{C}$

Manifold heat exchange rate, $\mathrm{W} / \mathrm{K}$

Tube heat loss coefficient, $\mathrm{W} / \mathrm{m}^{2} \mathrm{~K}$

Manifold heat loss coef., $\mathrm{W} / \mathrm{K} / \mathrm{m}$

Fin width for curved fin, $m$

Fin width for flat fin, $m$

Fin thickness, $m$

Fin thermal conductivity, $\mathrm{W} / \mathrm{mK}$

Ground albedo, -

Transmittance absorbance prod., - 


\title{
Improved Windows for Cold Climates
}

Jacob Birck Laustsen, Ass. Research Professor, Department of Civil Engineering, Technical University of Denmark, jbl@byg.dtu.dk

Svend Svendsen, Professor, Department of Civil Engineering, Technical University of Denmark, ss@byg.dtu.dk

\begin{abstract}
A large part of the energy consumption in countries in Nordic and Arctic climates is used for space heating in buildings. In typical buildings the windows are responsible for a considerable part of the heat losses. Therefore there is a large potential for energy savings by developing and using windows with improved energy performance.

Traditionally evaluation of the energy performance of windows has focused on the thermal transmittance, but as windows differ from the rest of the building envelope by allowing solar energy to enter the building, the total solar energy transmittance is equally important. In the heating season in cold climates the solar gain through windows can be utilized for space heating which results in a corresponding reduction in the energy production that is often based on fossil fuels. A suitable quantity for evaluating the energy performance of windows in a simple and direct way is therefore the net energy gain, which is the solar gain minus the heat loss during the heating season. Especially in arctic climates where the heating season covers the whole year there is a large potential for exploiting the solar gain during the summer season. Furthermore the presence of snow increases the solar radiation because of the reflection.
\end{abstract}

In this paper the energy saving potentials for different window types have been examined by determining the net energy gains in Danish and Greenlandic climates. Furthermore the windows have been evaluated by performing building simulations of the heating demand in typical single-family houses in Denmark and Greenland. The examined windows are typical new windows from Nordic countries and new proposals of improved windows with low thermal transmittance and high total solar energy transmittance.

The results show that net energy gain can be increased considerably by reducing the frame width, which results in a larger transparent area causing a larger solar gain but still maintaining a low thermal transmittance. Using three layers of glass with large gaps, using very slim frame profiles, and omitting the edge constructions that normally causes thermal bridges achieve this. Applying shutters or low emissivity coated roller blinds incorporated in the glazing that are activated during night time can improve the energy performance of windows.

The results from this work show that it is possible to develop windows with a positive net energy in a fairly simple way, which means that it contributes to the space heating of the building.

\section{INTRODUCTION}

In this paper the possibilities of improving the energy performance of windows in cold climates are examined. The background for using windows with improved energy performance is the need to reduce the energy consumption in buildings. Since the heat loss through windows often represents half the total heat loss from houses, developing and using 
better windows with respect to energy performance can save much energy. The main purpose of having windows in houses is that they provide daylight and view, but windows also provide solar gain that can be utilized as a contribution to the space heating in the building. Therefore the windows also have a positive influence on the energy balance of buildings.

To evaluate the possibilities for developing better windows with respect to energy performance when used in Nordic and arctic climates, seven different window types have been examined in terms of the net energy gain and simulations of the energy consumption in buildings with focus on domestic houses.

\section{THE NET ENERGY GAIN}

In order to evaluate the energy performance of windows both the $U$ value and g-value must be taken into account. The energy balance of windows over the heating season can be described by the net energy gain, which is the solar heat gain transmitted in through the window, minus the heat loss out through the window during the heating season. Thus, the net energy gain expresses the heat balance in one single number and is therefore a good measure to evaluate and compare the energy performance of windows in a simple and direct way.

The net energy gain, $E,\left[\mathrm{kWh} / \mathrm{m}^{2}\right]$ is given by the expression below (Nielsen, T. R. et al, 2000)

$$
E=I \cdot g-U \cdot G
$$

Where

I is the solar radiation during the heating season corrected for the g-value's

$G \quad$ is the degree hour during the heating season $[\mathrm{kKh}]$

$I$ and $G$ are dependent on the climate and $I$ is also dependent on the orientation of the window. A negative net energy gain indicates that the heat loss is larger than the solar gain.

\section{Danish climate}

The expression of the net energy gain for the Danish climate is based on the period from 24/9 to $13 / 5$ (heating season) and the following distribution of the windows:

$\begin{array}{llll}\text { - } & \text { South: } & 41 \% & \\ \text { - } & \text { North: } & 26 \% & \\ \text { - } & \text { East/West: } & & 33 \%\end{array}$

A shadow factor of 0.7 is used for the corrections for the effects of shadows. The net energy gain for Danish conditions is then given as (Nielsen, T. R. et al, 2000)
$E_{D k}=196.4 \cdot g-90.36 \cdot U$
$\left[\mathrm{kWh} / \mathrm{m}^{2}\right]$

\section{Greenlandic climate}

In order to evaluate the energy performance of the windows in arctic climates, an expression of the net energy gain, $\mathrm{E}_{\mathrm{Gl}}$, for Greenland were developed. $\mathrm{E}_{\mathrm{Gl}}$ is based on a reference house (typical in Greenland) with the same distribution of the windows as used for Denmark. 
As the climate in Greenland varies from north to south the country is divided into to two zones (Kragh, J. (2005)). The two zones cover Greenland north and south of the Arctic Circle respectively as shown in Figure 1.

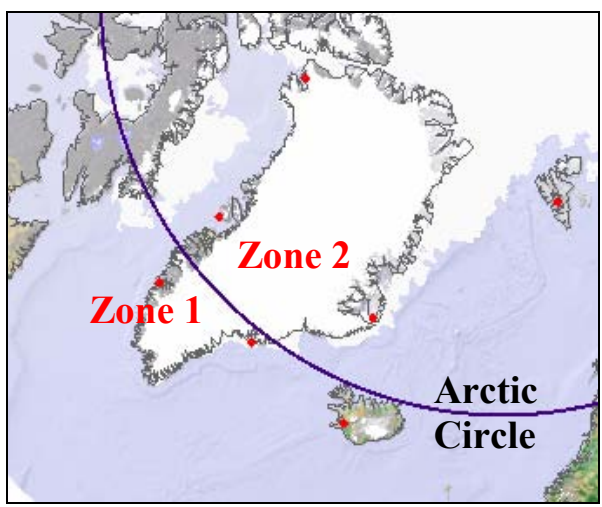

Figure 1: Climate zones in Greenland. Zone 1 south of the Arctic Circle and zone 2 north of the Arctic Circle (Kragh, J. (2005))

Based on the reference years for the two zones developed by (Kragh, J. (2005)) the following two expressions of the net energy gain were determined assuming that the heating season is a whole year.

$\begin{array}{lll}E_{G l_{-}=490 \cdot g-186 \cdot U}= & \text { Zone 1 } & {\left[\mathrm{kWh} / \mathrm{m}^{2}\right]} \\ E_{G l_{-2}}=532 \cdot g-223 \cdot U & \text { Zone 2 } & {\left[\mathrm{kWh} / \mathrm{m}^{2}\right]}\end{array}$

$E_{G l 2}=532$

A shadow factor of 0.7 is used for the corrections for the effects of shadows.

\section{DESCRIPTION OF THE REFERENCE HOUSES}

Two single-family houses were used for the calculations. The first one (A) is a typical house from Greenland that meets the Danish building code BR95, and the second house (B) is a typical Danish house that meets the coming Danish building code BR2005.
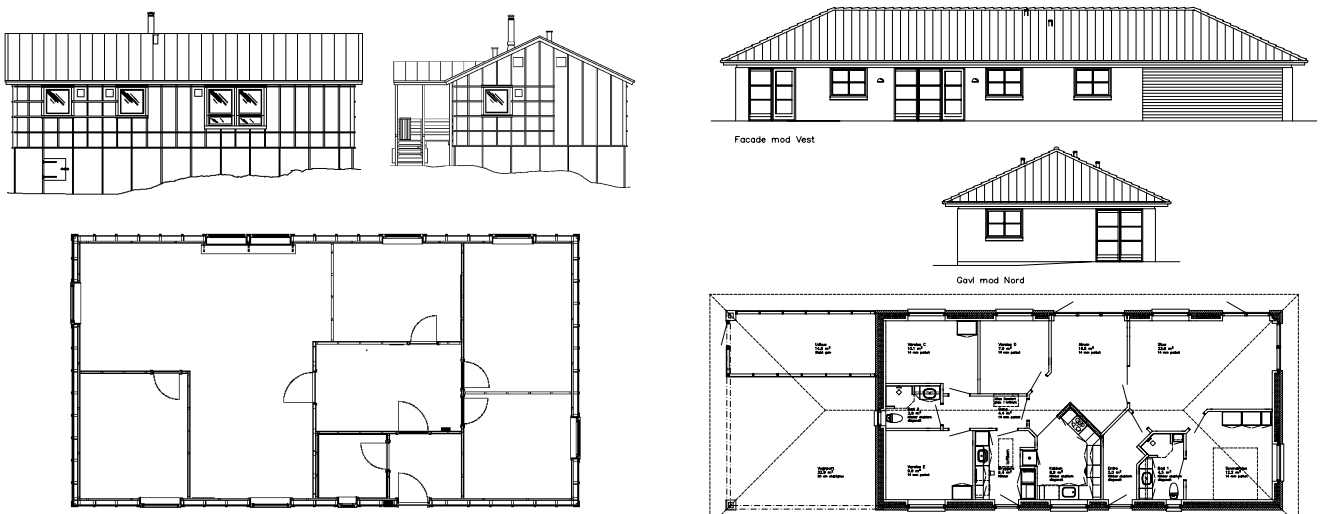

House A: (Arctic climate, Greenland)

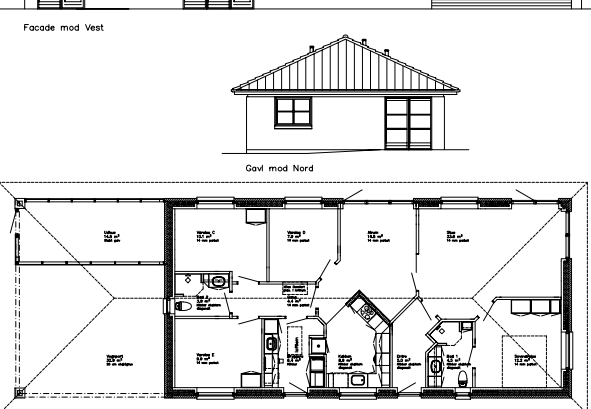

House B: (Danish climate)

Figure 2: The two houses used in the simulations in Bsim2002.

Data for the two houses used in the simulations are shown in Table 1

Table 1 Data for the two houses used in the calculations

\begin{tabular}{lll}
\hline & Area & Window area \\
\hline $\begin{array}{l}\text { House A, Arctic climate, } \\
\text { Greenland }\end{array}$ & $101.2 \mathrm{~m}^{2}$ & $12.3 \mathrm{~m}^{2}$ \\
\hline House B, Danish climate & $134.5 \mathrm{~m}^{2}$ & $30.1 \mathrm{~m}^{2}$ \\
\hline
\end{tabular}




\section{DESCRIPTION OF THE EXAMINED WINDOWS}

The energy performance was examined for seven different window types that will be described in the following.

\section{Type 1}

The standard window that is used in house A. The window is made of wood and has a double glazing unit with argon and low emissivity in position 3.

\section{Type 2}

The standard window that is used in house B. The window is made of wood and has a double glazing unit with argon and low emissivity in position 3 .

\section{Type 3}

The third window shown in Figure 3 is developed at Technical University of Denmark. The frame profiles are made of wood covered with aluminium. The used glazing is a double layer low energy glazing 4-15-4 mm with 90/10\% argon filling in the gap and a low-emittance coating on the inner pane on the surface facing the gap. To get a high g-value the outer pane is made of float glass with low iron content.

The used edge construction is a "warm edge". The spacer is made of plastic with a very thin stainless steel film, which ensures that the edge construction is tight and the argon gas stays inside the glazing. The low thermal conductivity of the plastic material ensures that the equivalent thermal conductivity is several times lower than for traditional edge constructions of steel or aluminium.

Moving the sash out in front of the outer frame reduces its width to approximately $5 \mathrm{~cm}$. Hereby the glazing area is increased by $15 \%$ (for the standard window dimensions: $1.48 \mathrm{x}$ $1.23 \mathrm{~m}$ ) compared to a corresponding window of wood with a frame width of $10 \mathrm{~cm}$. In the bottom between the aluminium and the wood a weather strip of flexible elastomeric foam is mounted to prevent ventilation of the cavity between the aluminium and the wood. This reduces the U-value. (Laustsen, J. B et al (2003)).

To reduce the edge loss between window and wall the frame is made very deep $(226 \mathrm{~mm})$ to make it possible to cover a wide layer of insulation in the wall. Mounting a $3 \mathrm{~mm}$ PVC plate in the bottom of the frame facilitates this.

\section{Type 4}

Window type 4 shown in Figure 4 is a proposal for a frame construction of fibre glass reinforced polyester, which is both very slim and deep. There is room for 3 panes of glass with an unusually large gap, which has the effect that the depth of the frame is as much as 150 $\mathrm{mm}$. The frame can be made even deeper, however, and thus cover large insulation thicknesses in the wall. The window is called the combination window, as it combines glazing and sash into a more total construction.

As the total area of the window is $1.23 \mathrm{~m} \cdot 1.48 \mathrm{~m}$ and the frame width is $25 \mathrm{~mm}$, the glass percentage is $93 \%$. The centre U-value of the glazing is $0.93 \mathrm{~W} / \mathrm{m}^{2} \mathrm{~K}$ and the g-value is 0.58 . The glazing consists of three layers of glass: $4 \mathrm{~mm}$ float glass with hard low-e coating, 100 $\mathrm{mm}$ air, $4 \mathrm{~mm}$ float glass, $25 \mathrm{~mm}$ air and $4 \mathrm{~mm}$ float glass with hard low-e coating.

\section{Type 5}

This window is identical with type 4, but insulating shutters are mounted on the outside of the window. When the shutters are closed the U-value is reduced considerably. Closing the shutter when it is dark outside and there is no need for view out will therefore result in a reduced heat loss from the windows. The thermal resistance of the shutters is set to 1 $\mathrm{m}^{2} \mathrm{~K} / \mathrm{Wm}$, which corresponds to a thickness of $40 \mathrm{~mm}$ and a thermal conductivity of 0.039 $\mathrm{W} / \mathrm{mK}$. The thermal resistance of the extra cavity between the glazing and the shutter is neglected. 


\section{Type 6}

Typical Finnish window with a so-called " $1+2$ " glazing. Frame and sash are made of wood and aluminium. The glazing consists of one $4 \mathrm{~mm}$ layer float glass outermost, a large cavity of air and an insulating double glazing unit to the inside. The DGU has argon in the cavity and low emissivity coating in position 5. Window type 6 is shown in Figure 5.

\section{Type 7}

This is a German window that fulfils the requirements for the Passivhaus standard system. The frame profile is made from PVC insulated with PU-foam in the internal cavities, which results in a very low U-value. The glazing is a three layer low energy glazing (4/16/4/16/4) with argon in the cavities and two low emittance coatings. Window type 7 is shown in Figure 6

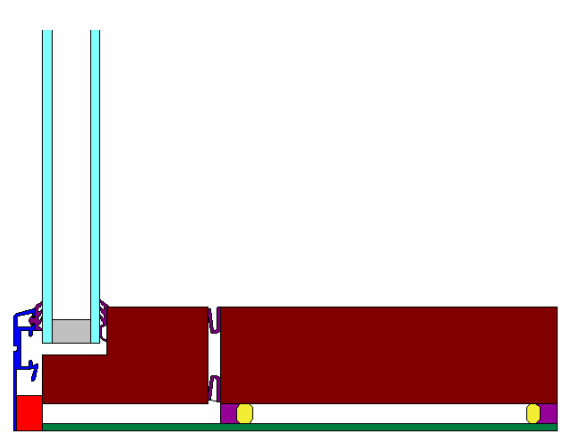

Figure 3. Type 3. Slim frame profile (5 $\mathrm{cm}$ ) made from wood covered with aluminium.

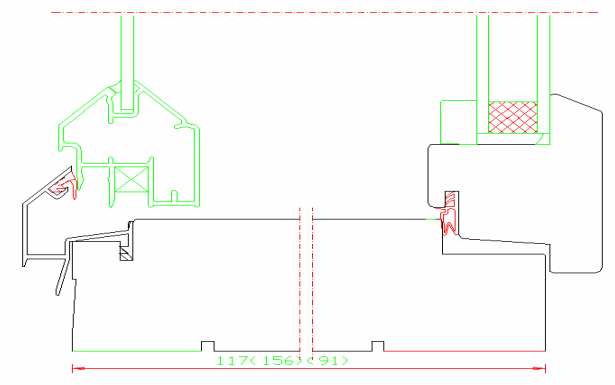

Figure 5. Type 6. Finnish window, 1+2 glazing. Frame made from wood and aluminium

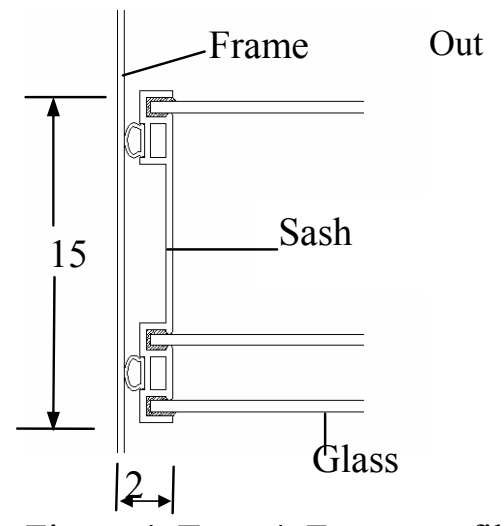

Figure 4. Type 4. Frame profile made from fibre glass reinforced polyester with three layers of glass.

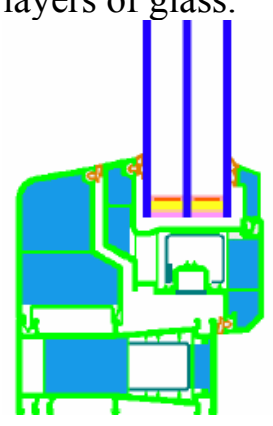

Figure 6. Type 7. PVC frame profile with PU foam in the cavities. Triple glazing unit. (Passivhaus.de.)

\section{Type 8}

In window type 8 a vacuum glazing was inserted in the standard frame profile made of wood used in window type 1 . The glazing has three layers of glass and it is a hybrid solution of a traditional low energy glazing with krypton in the gap and a glazing with a very small gap with vacuum. The glazing is further described on:

http://www.nsg-spacia.co.jp/spacia21/index.html 


\section{Type 9}

" $2+1$ " window. Frame and sash are made of wood, aluminium and PVC. The glazing consists from the outside of an insulating double glazing unit with argon and low emissivity coating, a large air gap of $110 \mathrm{~mm}$ and a single $4 \mathrm{~mm}$ pane with hard low emissivity coating inside.

\section{Data for the windows}

For each of the windows the thermal and optical properties were determined. The thermal transmittance, $U$, the linear thermal transmittance, $\Psi$, and the total solar energy transmittance, g, were determined in accordance with the standards EN ISO 10077-1 and 2 (CEN, 2003). Detailed calculations of $U$ and $\Psi$ were performed in the program Therm (LBNL (2003)). The net energy gain was determined for Danish climate and Greenlandic climate for zone and zone 2. In order to give a quick comparison of energy performance of the windows the net energy gain was determined for a standard size window. In Table 2 data and results for the examined windows are shown.

Table 2. Data for the examined windows. All windows measure the standard dimensions 1.23 $m \times 1.48 \mathrm{~m}$.

\begin{tabular}{|c|c|c|c|c|c|c|c|c|c|c|c|c|}
\hline & \multicolumn{4}{|c|}{ Glazing } & \multicolumn{3}{|c|}{ Frame } & \multicolumn{2}{|c|}{$\begin{array}{c}\text { Window } \\
1.48 \times 1.23 \mathrm{~m}\end{array}$} & \multicolumn{3}{|c|}{ Net energy gain } \\
\hline & Glazing & $\mathrm{U}_{\mathrm{g}}$ & $\mathrm{g}$ & $\tau$ & Width & $\mathrm{U}_{\mathrm{f}}$ & $\Psi$ & $\mathrm{U}_{\mathrm{tot}}$ & $\mathrm{g}_{\text {tot }}$ & $\mathrm{E}_{\text {ref }} \mathrm{Dk}$ & $\mathrm{E}_{\text {ref }}$ Zone 1 & $\mathrm{E}_{\text {ref }}$ Zone 2 \\
\hline Type & & $\mathrm{W} / \mathrm{m}^{2} \mathrm{~K}$ & & & $\mathrm{M}$ & $\mathrm{W} / \mathrm{m}^{2} \mathrm{~K}$ & W/Mk & $\mathrm{W} / \mathrm{m}^{2} \mathrm{~K}$ & & $\mathrm{kWh} / \mathrm{m}^{2}$ & $\mathrm{kWh} / \mathrm{m}^{2}$ & $\mathrm{kWh} / \mathrm{m}^{2}$ \\
\hline 1 & 2 layers & 1.28 & 0.63 & 0.66 & 0.10 & 1.30 & 0.128 & 1.61 & 0.46 & -56 & -76 & -116 \\
\hline 2 & 2 layers & 1.17 & 0.63 & 0.79 & 0.10 & 1.37 & 0.047 & 1.34 & 0.46 & -32 & -26 & -57 \\
\hline 3 & 2 layers & 1.15 & 0.67 & 0.80 & 0.054 & 1.33 & 0.034 & 1.27 & 0.58 & -2 & 41 & 18 \\
\hline 4 & 3 layers & 0.93 & 0.58 & 0.65 & 0.025 & $1.49 *)$ & - & 0.97 & 0.54 & 18 & 83 & 70 \\
\hline 5 & 3 layers & 0.93 & 0.58 & 0.65 & 0.025 & $1.49 *)$ & - & $\begin{array}{c}0.97 \\
\left.0.49^{* *}\right)\end{array}$ & $\begin{array}{c}0.54 \\
\left.0.0^{* *}\right)\end{array}$ & 45 & & \\
\hline 6 & $1+2$ & 1.01 & 0.60 & 0.71 & 0.11 & 1.32 & 0.040 & 1.20 & 0.43 & -23 & -10 & -36 \\
\hline 7 & 3 layers & 0.70 & 0.52 & 0.70 & 0.13 & 0.75 & 0.030 & 0.79 & 0.33 & -6 & 16 & 0 \\
\hline 8 & $2+$ vacuum & 0.70 & 0.43 & 0.64 & 0.10 & 1.30 & $0.05 * * *)$ & 0.99 & 0.31 & -39 & -33 & -57 \\
\hline 9 & $2+1$ & 0.72 & 0.51 & 0.67 & 0.055 & 2.71 & - & 1.03 & 0.43 & -9 & 18 & -2 \\
\hline
\end{tabular}

*) Calculations of the thermal properties of glazings/windows with large cavities do not include a linear thermal transmittance, $\Psi$, because of the special method used (Jensen, C. (2001)). Any extra two dimensional heat losses due to the interaction between frame and glazing is included in the thermal transmittance, $U$, for the frame.

**) With shutters. Shutters are closed when it is dark. In Danish climate 63\% of the degree hours in the heating season occur when it is dark. (Madsen. T.T. (2004))

***) Assumed

The calculations of the net energy gains show that the goal of developing windows for Nordic and arctic climates with positive net energy gain can be obtained with the proposed new windows. The window type 3, 4(5) and 7 have the largest net energy gains. Although window 7 has the lowest U-value window 3 and 4 have higher net energy gains, which indicate that increasing the g-value by reducing the frames width has a positive impact on the net energy gain because more solar energy is transmitted. 


\section{SIMULATIONS OF ENERGY CONSUMPTION}

Simulations of the energy consumption were performed in the program Bsim2002 (By \& Byg (2002)) for the two houses with the different windows inserted. For house A calculations are carried out for Greenland (weather data zone 1 and zone 2) assuming heating season during the whole year. For house B calculations are carried out for Danish weather data (Copenhagen) assuming heating season from September $7^{\text {th }}$ to May $6^{\text {th }}$. Window 1 was not examined in house B. The results of the simulations are shown in Table 3 , Figure 8 and figure 9.

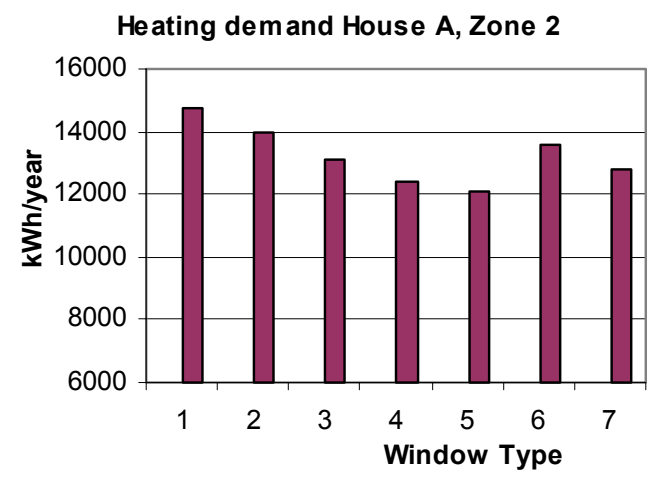

Figure 8 Heating demand for house A with different windows, Greenland, zone 2.

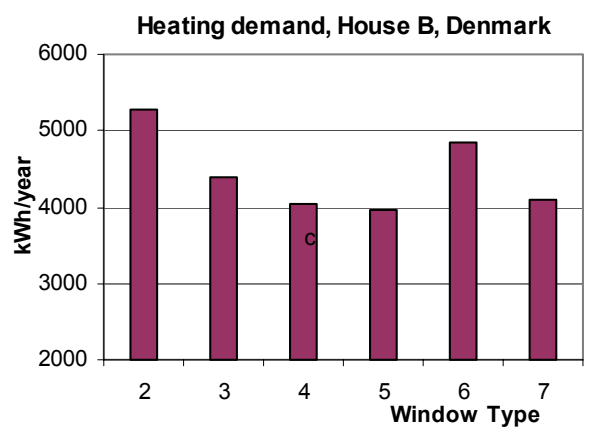

Figure 7. Heating demand for house B with different windows, Denmark

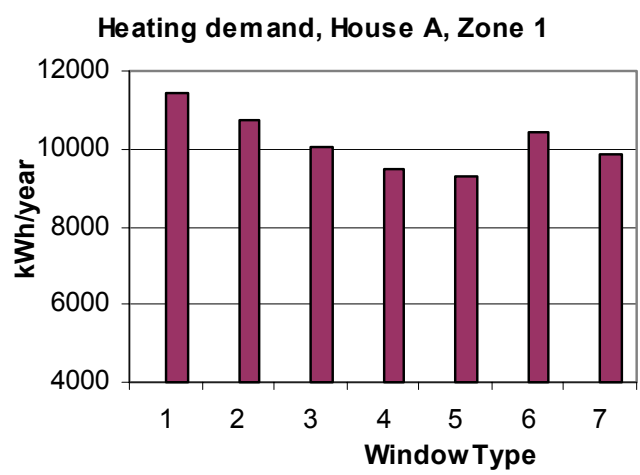

Figure 9. Heating demand for house A with different windows, Greenland, zone 1 .

Table 3: Energy consumption in house A, Greenland (Zones 1 and 2) with different windows.

\begin{tabular}{|c|c|c|c|c|c|c|c|c|}
\hline \multicolumn{3}{|c|}{ Window } & \multicolumn{3}{|c|}{ Zone 1} & \multicolumn{3}{|c|}{ Zone 2} \\
\hline Ty & $\begin{array}{l}\mathrm{J}_{\text {tot }} \\
\mathrm{V} / \mathrm{m}^{2} \mathrm{~K}\end{array}$ & $\mathrm{~g}_{\text {tot }}$ & $\begin{array}{l}\text { Heating } \\
\mathrm{kWh} / \text { year }\end{array}$ & $\begin{array}{l}\text { Solar gain } \\
\mathrm{kWh} \text { /year }\end{array}$ & $\begin{array}{l}\text { Venting } \\
\text { kWh/year }\end{array}$ & $\begin{array}{l}\text { Heating } \\
\mathrm{kWh} / \text { year }\end{array}$ & $\begin{array}{r}\text { Solar gain } \\
\mathrm{kWh} \text { /year }\end{array}$ & $\begin{array}{l}\text { Venting } \\
\text { kWh/year }\end{array}$ \\
\hline 1 & 1.61 & 0.46 & 11427 & 3016 & -247 & 14751 & 3324 & -200 \\
\hline 2 & 1.34 & 0.46 & 10744 & 3016 & -275 & 13930 & 3324 & -230 \\
\hline 3 & 1.23 & 0.58 & 10024 & 3830 & -558 & 13254 & 4107 & -460 \\
\hline 4 & 0.97 & 0.54 & 9488 & 3578 & -498 & 12434 & 3956 & -462 \\
\hline 5 & $\begin{array}{c}0.97- \\
0.49\end{array}$ & $\begin{array}{c}0.54 \\
0.0\end{array}$ & 9294 & 3536 & -498 & 12090 & 3896 & -459 \\
\hline 6 & 1.20 & 0.43 & 10455 & 2872 & -252 & 13580 & 3166 & -210 \\
\hline 7 & 0.79 & 0.33 & 9830 & 2204 & -136 & 12811 & 2426 & -113 \\
\hline
\end{tabular}

Heating: Energy consumption for space heating in the building.

Solar gain: Solar energy transmitted through the windows to the building, $\mathrm{kWh}$.

Venting: Heat loss due to ventilation by opening windows and doors, $\mathrm{kWh}$. 
Table 4. Energy consumption for house B(Denmark) with different windows.

\begin{tabular}{|c|c|c|c|c|c|}
\hline \multicolumn{2}{|c|}{$\mathrm{U}_{\text {tot }}$} & $g_{\text {tot }}$ & Heating & Solar gain & Venting \\
\hline Тур & $\mathrm{W} / \mathrm{m}^{2} \mathrm{~K}$ & & $\mathrm{kWh} /$ year & kWh/ year & $\mathrm{kWh} /$ year \\
\hline 2 & 1.34 & 0.46 & 5274 & 1891 & -136 \\
\hline 3 & 1.23 & 0.58 & 4401 & 2705 & -423 \\
\hline 4 & 0.97 & 0.54 & 4032 & 2373 & -344 \\
\hline 5 & $\begin{array}{c}0.97- \\
0.49\end{array}$ & $\begin{array}{c}0.54- \\
0.0\end{array}$ & 3949 & 2349 & -353 \\
\hline 6 & 1.20 & 0.43 & 4836 & 1901 & -162 \\
\hline 7 & 0.79 & 0.33 & 4093 & 1582 & -131 \\
\hline
\end{tabular}

It appears from the calculations that considerable energy savings can be achieved by improving the existing windows (types 1 and 2). Type 3, which is based on quite simple improvements (slim frame and the best DGU on the Danish market) saves between $12-17 \%$ of the energy consumption.

Type 4 reduces the energy consumption by $17-24 \%$. The advantage of this window is the large glazing area due to the extremely narrow frame profile in combination with the low Uværdi. Type 5 (= type $4+$ shutter) results in savings of $19-25 \%$ due to the further reduced Uvalue during night time when the shutters are closed. Type 6 only saves about $8 \%$ of the heating demand. However, it is expected that reducing the frame width and applying hard low-e coating on the outermost glass pane can improve the energy performance of this window type. Furthermore, a thermal break in the aluminium sash will reduce the U-value. Type 7 results in energy savings of $14-22 \%$ due to the very low U-value of both the frame profile and the glazing. However, the wide frame profile and the three layers of glass with two low-e coatings have the effect that the total solar energy transmittance is only 0.33 for which reason the window does not exploit the solar gain to optimum effect.

The results show that the largest energy savings are obtained using the window types 4,5 and 7. By developing hybrid solutions that combine type 7's very low U-values of both frame and glazing with the slim frame construction in type 4, which increases the g-value, it will be possible to obtain even higher net energy gain.

It appears that the windows type 3 and 4/5 that have high g-values due to large glazing areas provide a large solar gain, which is good for the energy balance, but this can also result in overheating problems in warm periods with sunny days. Therefore, the demand for venting is higher for these windows. Applying solar shading devices can solve most of these problems.

\section{CONCLUSION}

Based on the calculations of the net energy gain and the heating consumption of seven different windows it is concluded that there are good possibilities for developing windows with improved energy performance for cold and arctic climates. The windows type 3,4,5 and 7 results in the highest net energy gains and the lowest energy consumptions in the houses. For type 7 the good result is due to the very low thermal transmittance. An unfortunate effect of the combination of the wide frame profile and the three-layer glazing is that the total solar energy transmittance is quite low resulting in a low solar gain. 
The good results for window type 3,4 and 5 show that the g-value has a significant influence on the energy performance. A simple and efficient way to improve the g-value is by increasing the glazing area by reducing the frame width. In the new developed window type 4 this is implemented with a frame width of only $25 \mathrm{~mm}$ and still keeping a low U-value. The three layer glazing with large gaps, ensures that the use of edge constructions that normally results in a thermal bridge can be avoided.

Since the windows with low U-value and high g-value result in positive net energy gain they will contribute to the space heating of the houses. During periods with sunny days the high solar gain can cause overheating problems. Therefore there is a need for developing windows with integrated solar shading devices.

\section{ACKNOWLEDGEMENT}

The Villum Kann Rasmussen Foundation financed the work presented in this paper.

\section{REFERENCES}

By \& Byg (2002). Bsim 2002 - Building simulation program, Dansih Building and Urban Research, Hørsholm, Denmark.

CEN (2000). EN ISO 10077-1. 2000. European Standard. Thermal performance of windows, doors and shutters - calculation of thermal transmittance - Part 1: Simplified method.

CEN (2003). EN ISO 10077-2. 2003. European Standard. Thermal performance of windows, doors and shutters - calculation of thermal transmittance - Part 2: Numerical method for frames.

Jensen, C. F. 2001 Beregningsprocedure for de energimæssige forhold for forsatsvinduer. Department of Civil Engineering, Technical University of Denmark.

Kragh, J. (2005). Weather Test Reference Years of Greenland. Department of Civil Engineering, Technical University of Denmark.

Laustsen, J. B. Svendsen, S. (2003). Windows with improved energy performances. ISES Solar World Congress, Göteborg, Sweden, 2003.

LBNL (2003). Therm ver. 5.2, Finite element simulator, (2003), Lawrence Berkley National Laboratory, USA.

Madsen, T. T. (2004). Vinduer med bedre energimoessige egenskaber. Department of Civil Engineering, Technical University of Denmark.

Nielsen, T. R., Duer, K., Svendsen, S (2000). Energy Performance of Glazings and Windows. Solar Energy Vol. 69(Suppl.), Nos. 1-6, pp. 137-143, 2000.

TNO. (2004). Advanced Window Information System, WIS -window simulation program, TNO Building and Construction Research, Delft (NL). 2004 


\title{
Mechanical ventilation systems with heat recovery in arctic climate
}

Jesper Kragh, Assistant Professor, Department of Civil Engineering, Technical University of Denmark, jek@byg.dtu.dk

Svend Svendsen, Professor, Department of Civil Engineering, Technical University of Denmark, ss@byg.dtu.dk

\begin{abstract}
Mechanical ventilations systems with highly effective heat recovery units in arctic climate have problems with condensing water from the extracted humid indoor air. If the condensing water freezes to ice in the heat recovery unit, the airflow rate will quickly diminish due to the increasing pressure drop.

Preheating the inlet air (outdoor air) to a temperature just above $0^{\circ} \mathrm{C}$ is typically used to solve the problem. To minimize the energy cost, a more efficient solution to the problem is therefore desirable. In this project a new design of a heat recovery unit has been developed to the low-energy house in Sisimiut, which is capable of continuously defrosting itself. The disadvantage of the unit is that it is quite big compared with other units. In this paper the new heat recovery unit is described and laboratory measurements are presented showing that the unit is capable of continuously defrosting itself. Nevertheless, extra heating is still necessary in very cold periods to avoid draft for occupants.
\end{abstract}

\section{INTRODUCTION}

Appropriate ventilation of houses in cold climates is of great importance. The low outside temperature and poor insulated building constructions increases the risks of condensation (on cold surfaces) of the humid room air. This can lead to rot and fungus damages and result in an unhealthy indoor climate.

Traditionally mechanical ventilation system with heat recovery consists of two fans, a heat exchanger, filters, ducts, inlet and outlet diffusers and a controlling system. Using a heat exchanger with high efficiency will typically reduce the ventilation heat loss by $80-90 \%$ and the total heat loss by $30-60 \%$, depending on the insulation level of the house etc. The inlet diffusers are placed in rooms where the people are present over longer periods of time, i.e. the living room and bedrooms while outlets are normally placed in the rooms where moisture, odour and other pollutants of the indoor environment are produced, i.e. the kitchen, bathrooms and scullery. In this way the moisture and odour from cooking and bathing etc. are removed effectively without polluting the surrounding rooms, while fresh air is blown into the building, providing a good indoor climate.

The disadvantages of using mechanical ventilation systems are higher installation costs, necessary space for the components and ducts and very importantly, the electricity consumption of the fans. In the design phase of a ventilation system, the attention must always be on minimizing the pressure losses in the system, as the electricity used by the fans this is directly proportional to the total pressure drop in the system.

Mechanical ventilation with heat recovery in cold climates can present problems with ice formation in the heat exchanger. That is, when the warm humid room air is brought in contact with the cold surfaces of the exchanger (cooled by the outside air), the moisture in the exhaust air condensates in the heat exchanger. If the outside air temperature is below zero, the water vapour will freeze resulting in a larger air flow resistance on the exhaust side of the heat 
exchanger, which in turn decreases the air flow. The decrease in the amount of warm air through the exchanger will result in the exchanger being cooled further, and the system will eventually stop.

\section{LABORATORY TEST OF A STANDARD HEAT RECOVERY UNIT}

At the Technical University of Denmark a laboratory test has been performed on a typical heat recovery unit in order to investigate how the airflow is influenced by the condensation and ice formation in the heat exchanger. The unit consists of two ventilators and a counter flow heat exchanger made of plastic with an expected temperature efficiency of $90 \%$. The built-in feature to avoid ice in the system was deactivated during the test. The test was performed using cold inlet air at $-5^{\circ} \mathrm{C}$ and warm exhaust room air at $21^{\circ} \mathrm{C}$ (relative humidity of air: 42\%). As shown in Figure 1 the exhausted airflow after only 2 hours starts to fall due to the ice formation inside the exchanger. This means that in cold climates the built-in feature to avoid ice in the heat exchanger would be initiated continuously influencing the airflow rates significantly and thereby the recovered heat. For Nuuk the heat exchanger would use the built-in feature to avoid ice $30 \%$ of the year.

(16 hours)

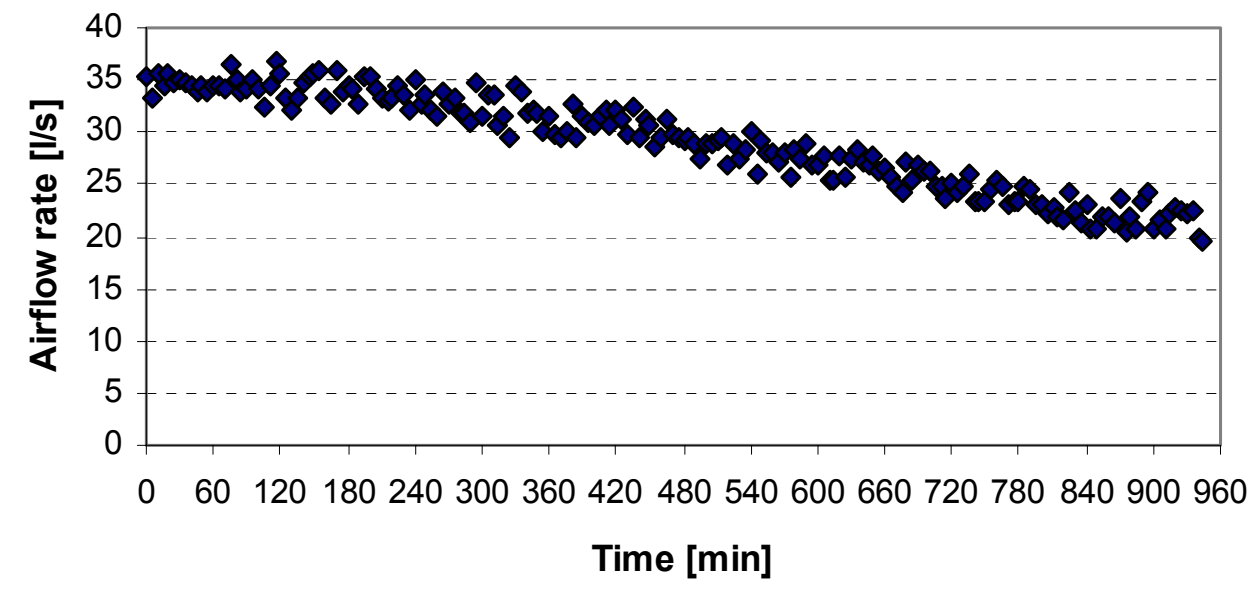

Figure 1 Measurements of the exhaust air flow rate through a standard heat recovery unit at low outside temperature $\left(-5^{\circ} \mathrm{C}\right)$.

\section{PREHEATING THE VENTILATION AIR}

Preheating the cold inlet air before reaching the exchanger is often used to solve the problem. In Figure 2 an example of the energy used for preheating the outside air is shown for the climate in Sisimiut. The calculation assumed a reference house of $100 \mathrm{~m}^{2}$ with a room height of $2.5 \mathrm{~m}$ and an air change rate of $0.5 \mathrm{~h}^{-1}$ according to the building code. 


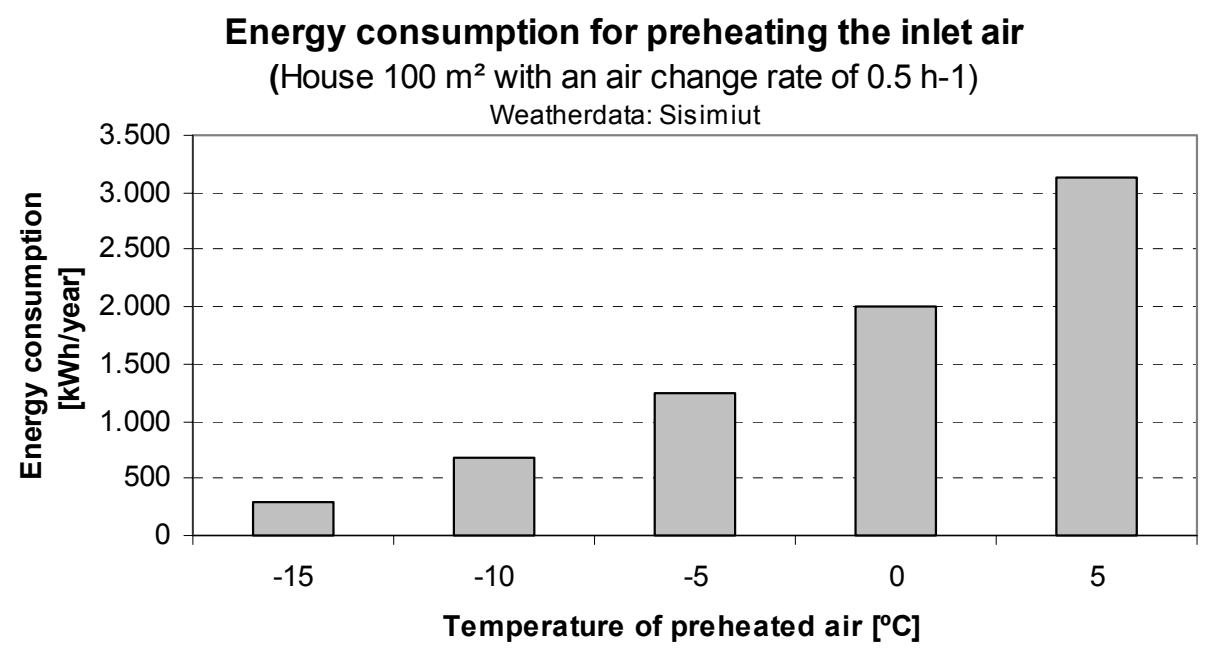

Figure 2 Energy consumption for preheating the ventilation air in a $100 \mathrm{~m}^{2}$ house at an air change rate of $0.5^{-1}$ according to the building code and a room height of 2.5 $\mathrm{m}$.

As the preheating system requires extra energy and higher installation costs it is not the optimum solution.

\section{THE VENTILATION HEAT LOSS}

The ventilation heat loss in a typical $100 \mathrm{~m}^{2}$ Greenlandic house located in Sisimiut is approximately $9.000 \mathrm{kWh} /$ year (at an air change rate of $0.5 \mathrm{~h}^{-1}$ ). In Table 1 the energy consumption for the ventilation system is compared for: ventilation system with no heat recovery, ventilation with heat recovery and preheating system and the future ventilation system with only heat recovery.

Table 1 The ventilation heat loss for a $100 \mathrm{~m}^{2}$ house in Sisimiut.

\begin{tabular}{lcccc}
\hline & $\begin{array}{c}\text { Ventilation } \\
\text { heat loss } \\
\mathrm{kWh}\end{array}$ & $\mathrm{kWh}$ & $\mathrm{kWh}$ & $\mathrm{kWh}$ \\
\hline $\begin{array}{l}\text { Ventilation with no } \\
\text { heat recovery }\end{array}$ & 9.000 & 0 & 0 & 0 \\
\hline $\begin{array}{l}\text { Standard system } \\
\text { with preheating }\end{array}$ & 700 & 2000 & 600 & 5.700 \\
\hline $\begin{array}{l}\text { Future system with } \\
\text { no preheating }\end{array}$ & 900 & 0 & 600 & 7.500 \\
\hline
\end{tabular}

\section{NEW DEVELOPED HEAT RECOVERY UNIT WITH FROST PROTECTION}

A new design of a heat recovery unit was developed for the low energy house in Sisimiut in corporation between EXHAUSTO A/S and the Technical University of Denmark. The dimension of the unit is: Length $1.760 \mathrm{~mm}$, width $930 \mathrm{~mm}$ and height $660 \mathrm{~mm}$. The unit consists of two highly efficient aluminium counter flow heat exchangers coupled in a serial connection. One valve is able to switch the air flow direction through the units. When ice formation starts to reduce the airflow in the coldest exchanger the air flow direction is switched. The exchangers, valve and filters are mounted in a cabinet with $50 \mathrm{~mm}$ insulation, even though the unit is recommend to be placed in a heated place to minimize risks of frost damages from the condensing water. A diagram of the system is shown in Figure 3. 


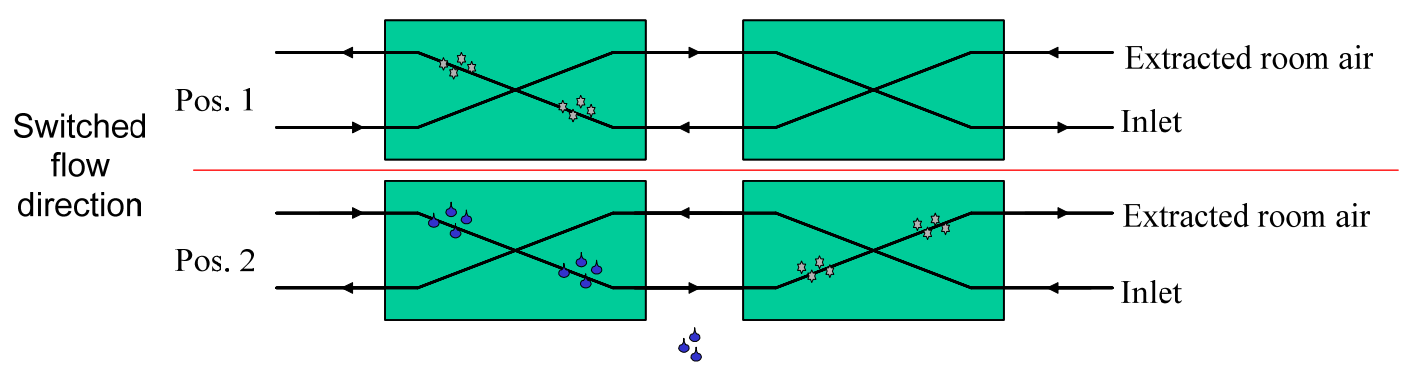

Figure 3 Diagram of the heat recovery unit with two heat exchangers. One valve and a timer switch the flow direction when ice formation reduces the air flow.

Two pictures of the heat recovery unit are shown in Figure 4. One valve and a timer switch the air flow direction, when ice formation reduces the flow. The condensing water is lead out through the bottom of the unit.
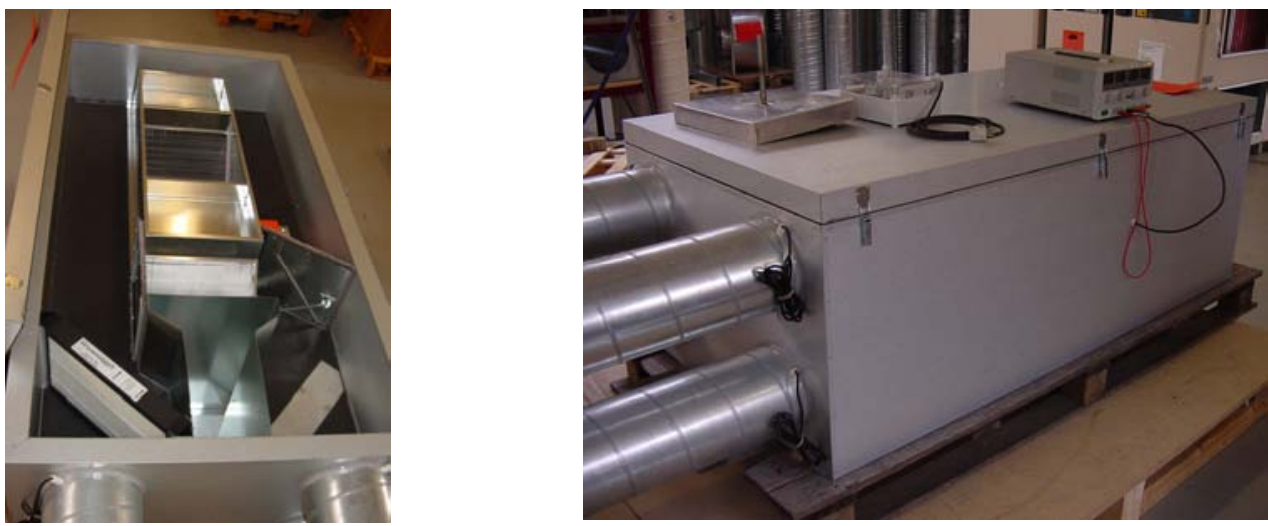

Figure $4 \quad$ Pictures of the heat recovery unit.

\section{LABORATORY TESTS}

The heat recovery unit designed for the low energy house in Sisimiut was tested in laboratory facilities at the Technical University of Denmark. The test was carried out using an outside temperature of approximately $-8^{\circ} \mathrm{C}$ and an inlet airflow rate of approximately $260 \mathrm{~m}^{3} / \mathrm{h}$. The tests showed that the defrosting system functioned as intended. In very cold periods, however, the system still needs extra heating of the inlet air to avoid draft caused by too low inlet temperature. The measurements are shown in Figure 5. 


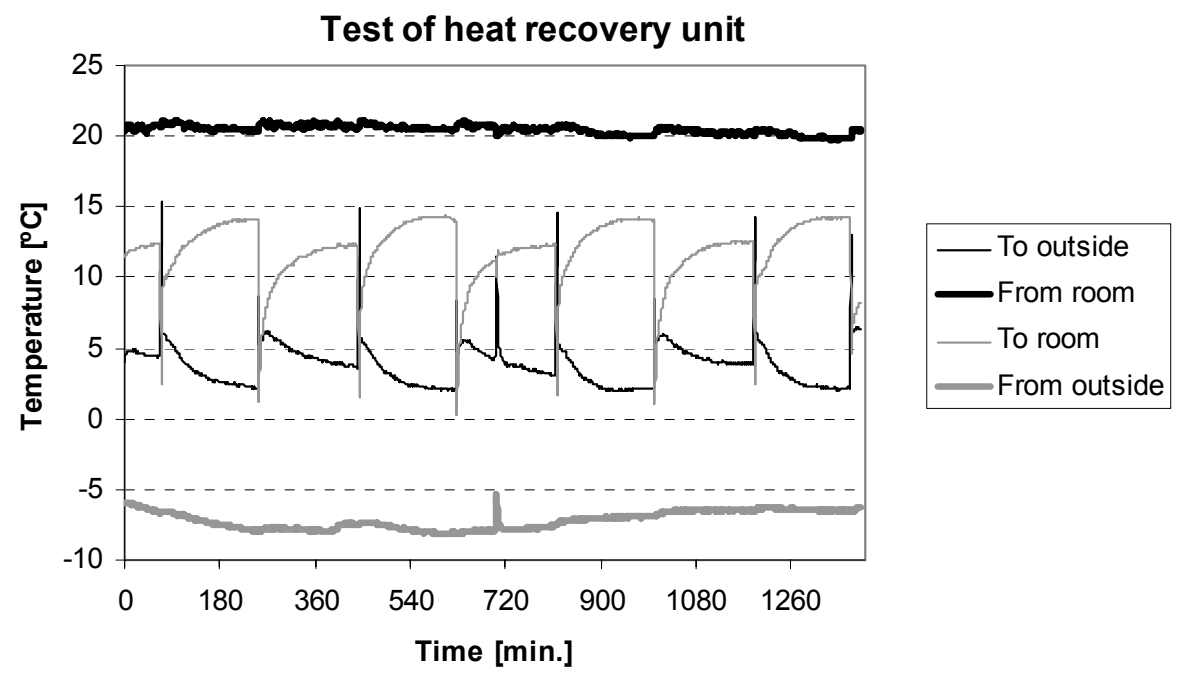

Figure 5 Laboratory measurement of the heat recovery unit.

As it can be seen from Figure 5 it is only necessary to heat the inlet temperature a few degrees before the inlet to the room.

\section{CONCLUSION}

In cold climates the potential of reducing the ventilation heat loss is huge. A standard heat recovery unit is not suitable for the cold arctic climate where the low outside temperature easily causes ice formation in the heat exchanger. Therefore a new heat recovery unit was designed and developed for the low-energy house in Sisimiut in corporation between EXHAUSTO A/S and the Technical University of Denmark. The developed heat recovery unit is capable of continuously defrosting it self. The defrosting system was tested under laboratory facilities showing that the system worked as intended but still there was a need for extra heating minimizing the risk of draft for the occupants.

\section{ACKNOWLEDGEMENT}

The Villum Kann Rasmussen Foundation financed the work presented in this paper. 


\title{
Solar Energy for Domestic Hot Water: Case Studies in Sisimiut
}

Gregers Reimann, Ph.D. student, Department of Civil Engineering, Technical University of Denmark,gr@byg.dtu.dk

\begin{abstract}
Two pioneer solar domestic hot water systems were installed at Bygge- og Anlægsskolen in Sisimiut in 1999 and 2000. Detailed measurements of energy flows and solar radiation incl. snow reflectance has been undertaken for both plants. Since August 2004 datalogging of the measurements was made available online on the website www.arcticsolar.com. Measurements show that solar plant 1 and 2 cover $22 \%$ and $23 \%$, respectively, of the energy spent for domestic hotwater heating. This paper summarises the findings from the past 5 years.
\end{abstract}

\section{SOLAR DOMESTIC HOT WATER PLANTS IN SISIMIUT}

The geographical location of both solar plants just north of the Arctic Circle, namely:

- Latitude: $66.93^{\circ} \mathrm{N}$

- Longitude: $53.68^{\circ} \mathrm{W}$

\section{PLANT 1:}

Size: $12 \mathrm{~m}^{2}$ (hot water)

Orientation: South-East

Tilt: $15^{\circ}$ from horizontal

Type: Batec BA30

Tank: Danlager 2000 (Nilan)

Location: 12 person dormitory

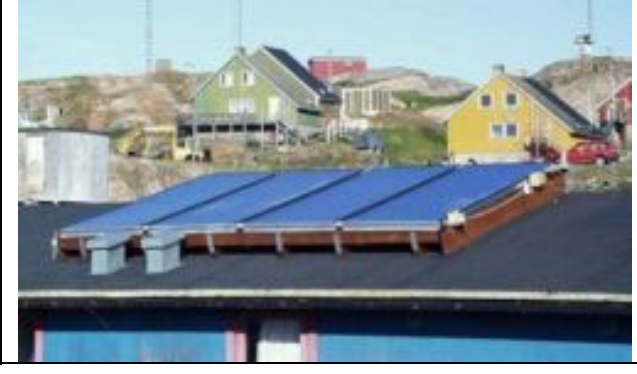

\section{PLANT 2:}

Size: $22 \mathrm{~m}^{2}$ (hot water)

Orientation: South-East

Tilt: $70^{\circ}$ from horizontal

Type: Batec BA22

Tank: Mantle 1000 liter

Location: Canteen building with washing mashines in basement

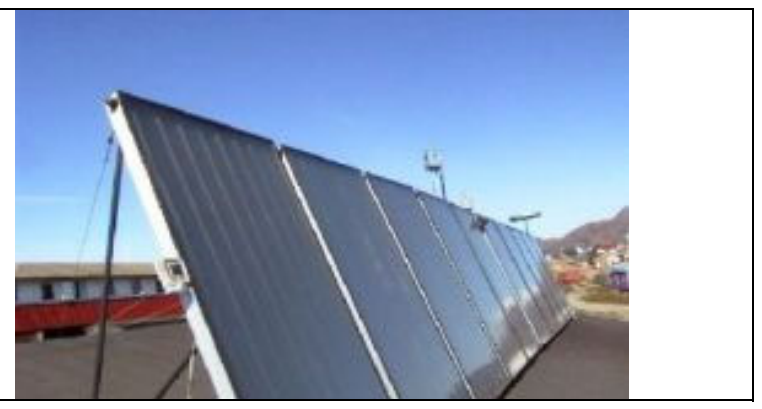




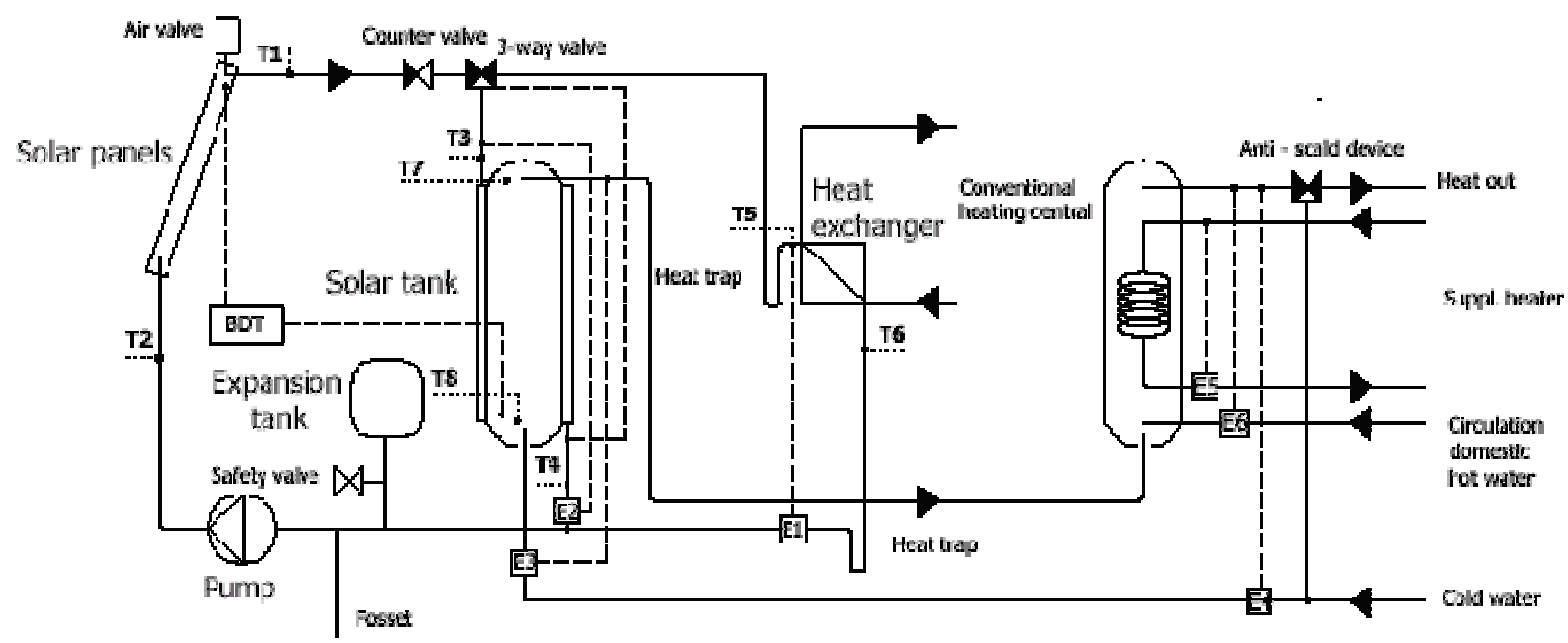

Figure 1: $\quad$ System diagram for plant 1 and 2. The energy meters labelled E1 - E6 are all data logged.

\section{PERFORMANCE DATA OF PLANT 1 AND 2}

Due to problems with irregular data collection and/or irregular solar plant operation from time to time it is difficult to perform a thorough analysis of the performance of the two plants. Since the online data logging was established in August 2004 is has been possible to undertake long distance monitoring of the solar systems, which has helped in diagnosing plant operation irregularities at an early stage, hence resulting in a more continuous operation of the solar plants.

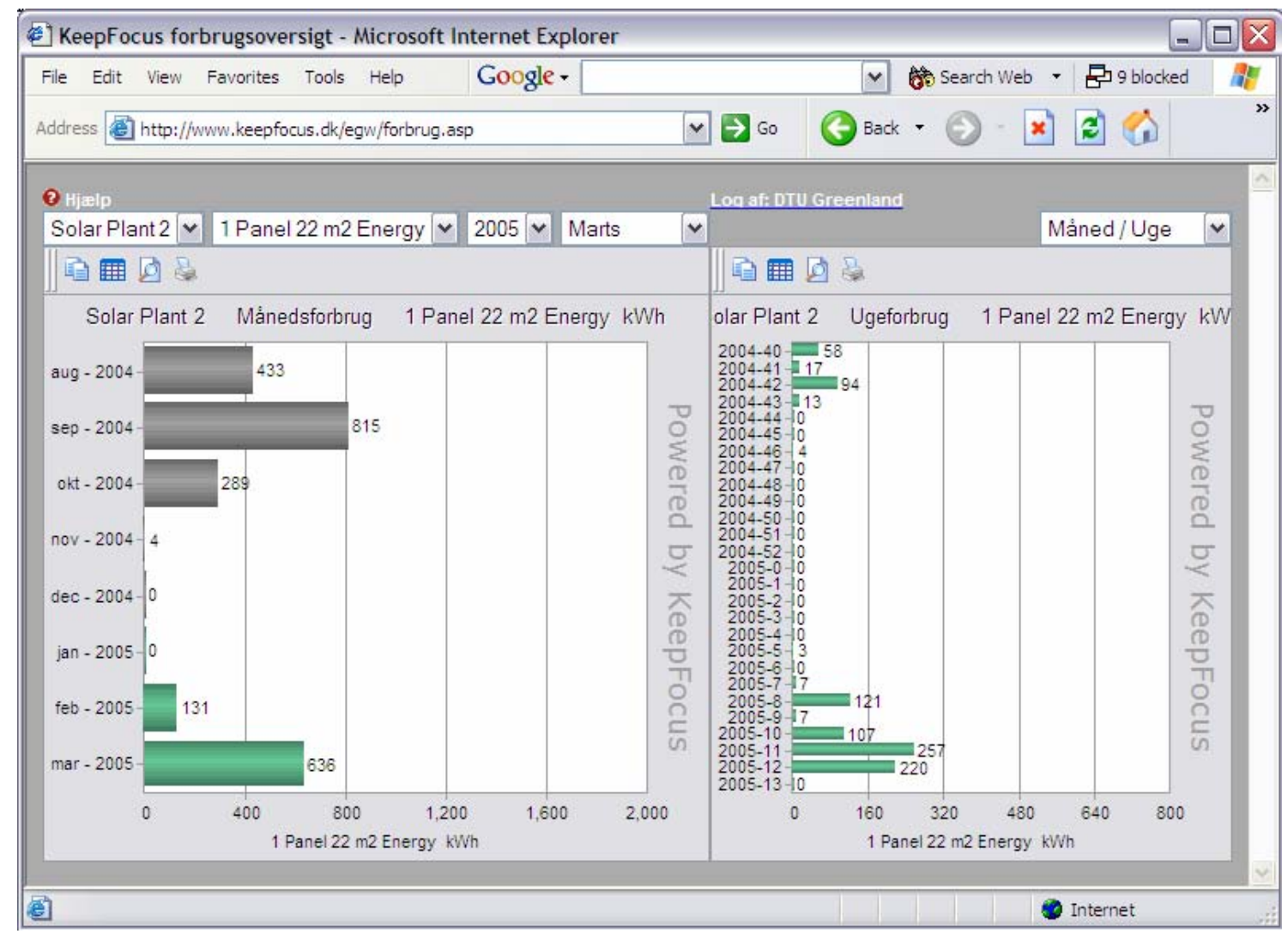


Figure 2: $\quad$ Screendump of the online data accessible for plant 1 and 2 on www.arcticsolar.com

\section{Solar Plant 1}

A full year of measured data was collected by manual readings in the period $13^{\text {th }}$ Oct. 1999 to $12^{\text {th }}$ Oct. 2000. The readings were done on more or less on a monthly basis. The data from energy meters 5 and 6 was not analysed, as the energy meters did not work properly.

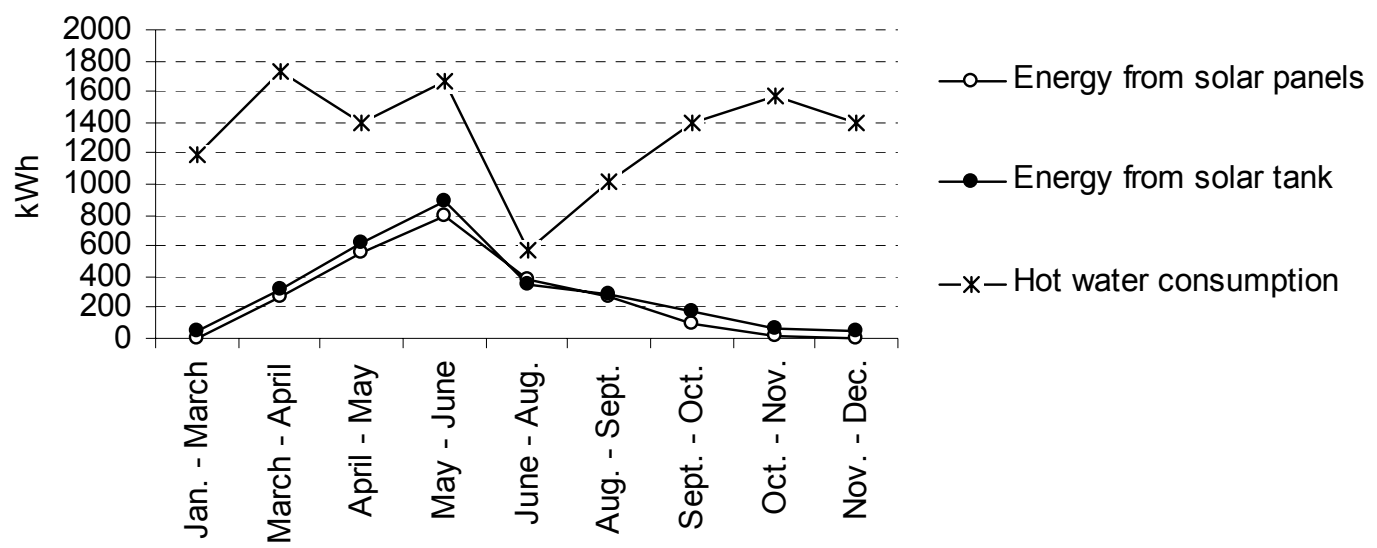

Figure 3: $\quad$ Measured data from plan 1 in the period $13^{\text {th }}$ Oct. 1999 to $12^{\text {th }}$ Oct. 2000

The small discrepancy between energy tapped from the solar panels and the energy tapped from the solar tank is caused by energy flows through the solar tank, namely into the tank in the winter and out of the tank in the summer. The solar tank is placed at room temperature inside the kitchen of the building.

The figure also shows that the hot water consumption is lowest during the summer when the solar radiation is the highest. From a solar utilisation point of view this is not optimal, as the available solar energy in the summer is not used to its fullest.

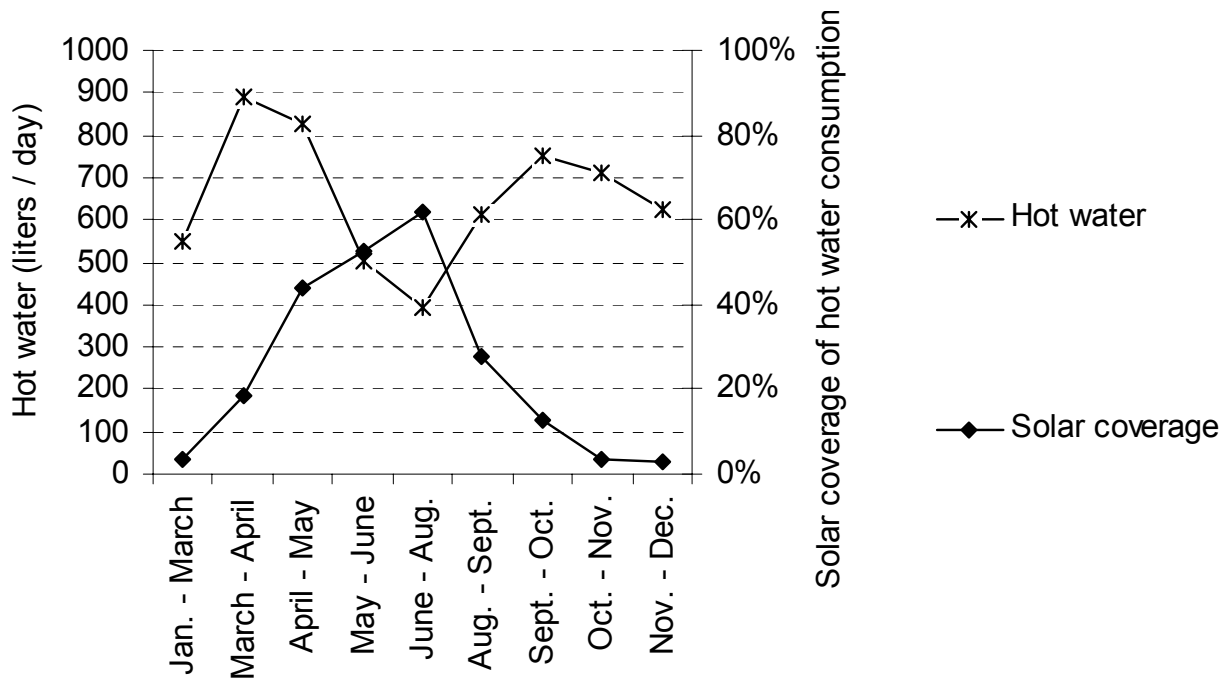

Figure 4: $\quad$ Plant 1 measurements of hot water consumption and solar coverage 
The figure shows that the solar system covers up to $60 \%$ of the energy spent for hot water consumption. On an annual basis the solar coverage of the hot water consumption was measured to $22 \%$, which correspond to a yield of $3217 \mathrm{kWh} /$ year or $268 \mathrm{kWh} / \mathrm{m} 2$ solar panel/year.

\section{Solar Plant 2}

A full year of measured month-by-month data for plant 2 does not exist. However, two manual measurements performed in July 2003 and again in July 2004 yielded the following annual energy break-up of the plant.

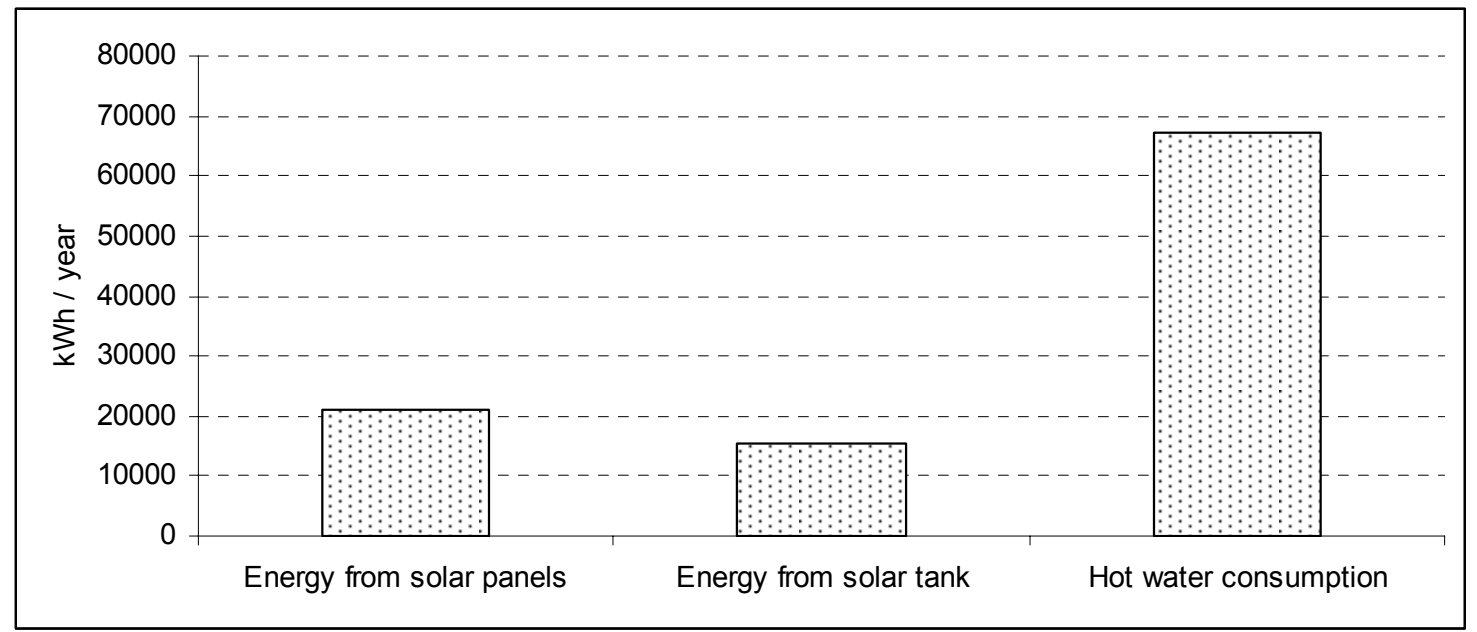

Figure 5: $\quad$ Plant 2 measurements for the period July 2003 to July 2004

Similarly to plant 1 there is a discrepancy between the energy delivered by the solar tank and the energy drawn from the solar tank due to energy flows through the solar tank.

On an annual basis the solar coverage of the hot water consumption was measured to $23 \%$.

The measured hot water consumption in the period Sept. 2004 - Feb. 2005 is 1260 liter / day. With this consumption the simulated yield for the solar plant should be around 375 $\mathrm{kWh} / \mathrm{m} 2 /$ year. 


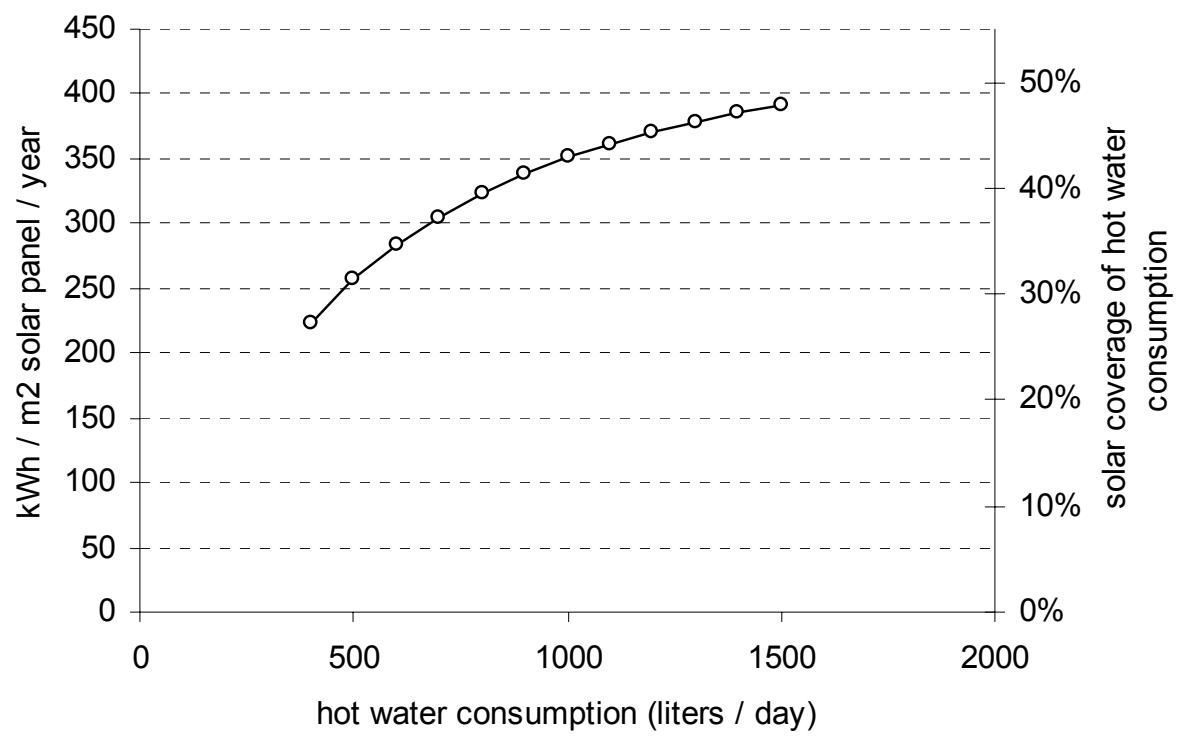

Figure 6: $\quad$ Simulation yield curve for plant 2

\section{SOLAR RADIATION}

The solar radiation and the radiation reflected by the ground is measured vertically East, West, North and South. The global radiation is also measured.

Sisimiut is covered by snow much of the year, so measuring the ground / snow reflectance is of interest, because the reflected radiation can contribute significantly solar collectors with a high inclination from horizontal. 

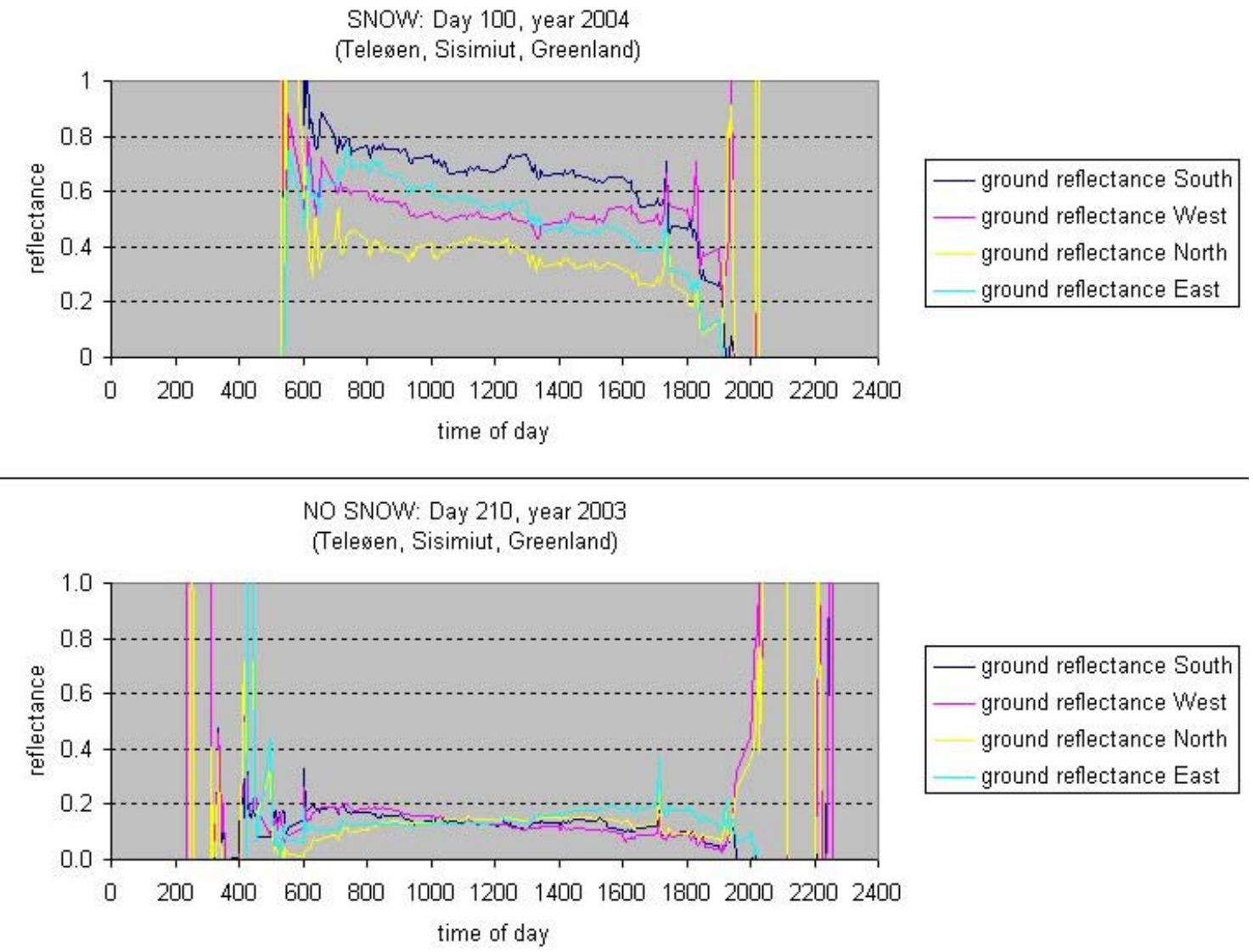

Figure 7: Ground reflectance measured in the winter (top) and in the summer (bottom)

\section{REFERENCES}

All material originates from the websites:

www.arcticsolar.com

http://www.byg.dtu.dk/subwebs/greenland/engelsk/index_eng.htm 


\title{
Description of wind resource measurements at Sarfannguaq and general reflections concerning use of wind energy in Greenland
}

\author{
Martin O.L.Hansen, Assoc. Professor, Department of Mechanical Engineering, Technical \\ University of Denmark, molh@mek.dtu.dk \\ Kurt S.Hansen, Assoc. Professor, Department of Mechanical Engineering, Technical \\ University of Denmark, ksh@mek.dtu.dk
}

\begin{abstract}
Wind resource measurements for a one year period in terms of wind speed, wind direction and temperatures at Sarfannguaq are presented. Furthermore, some reflections are made regarding a future implementation of wind energy in Greenland.
\end{abstract}

\section{INTRODUCTION}

It is often stated that wind energy is not suited for Greenland because there is not any significant wind resource, and if there is wind, then it is so high that the wind turbines has to be stopped for storm protection. In a student project from 2003 [1] the wind resources in Greenland, especially near Sisimiut, was investigated. According to [1] ASIAQ wind measurements from 1994 at 7 airports including Sisimiut, indicates that the wind resources in Greenland are limited. The mean wind speed at Sisimiut airport is $3.4 \mathrm{~m} / \mathrm{s}$, which is very low for wind energy purposes. However, the locations of the airports might have been chosen at low wind sites. In the mid $90^{\text {th }}$ it was, according to [1], suggested to measure the wind resources at Sarfannguaq, a small society of 116 people further inland in the fiords at Sisimiut. Unfortunately this was never done until the student project in 2003 [1], which showed that wind resources in Greenland might not be as low as often claimed. The location of the meteorological mast is shown in Figure 1, indicated as "Målemast". This meteorological mast has now been moved to, "Dumpen", Sisimiut where locals claim it is often windy.

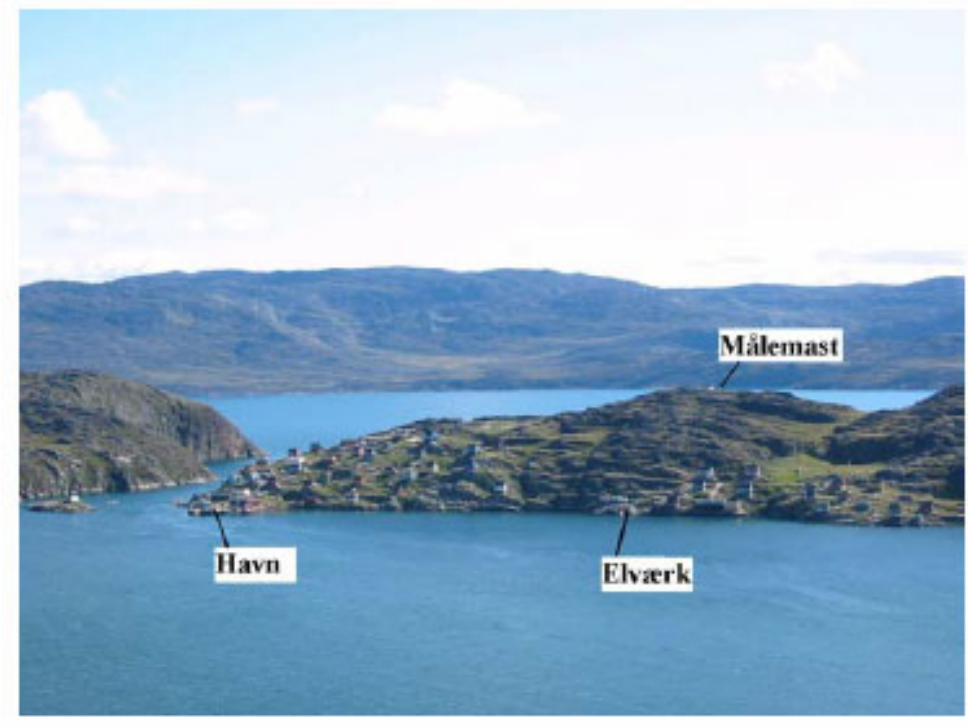

Figure 1 Photograph of Sarfannguaq also showing the position of the meteorological mast indicated as "Målemast" Photo: Jacob \& Henrik [1]. 


\section{MEASURED WIND IN SARFANNGUAQ}

A 10-meter high meteorological mast was installed in July 2003 at Sarfannguaq [1]. Measurements of the wind speed, wind direction and temperature were continuously made during the period July 2003 to August 2004 and the data are hosted on our wind database server (www.winddata.com), which contains measured wind data from many sites throughout the world. The meteorological mast was a commercially available mast from NRG-systems, including a cup anemometer, wind fane, thermometer located 10 meter above ground and datalogger. A memory plug was replaced 4 times by a local inhabitant of Sarfannguaq and send to DTU for postprocessing. The average wind speed measured at 10 meters height during this year was $6.25 \mathrm{~m} / \mathrm{s}$. It should, however, be noted that the height of the site of the metmast is $100 \mathrm{~m}$ above sea level. To have an idea of these numbers a resource map of Denmark is shown in Figure 2, referring to 45 meters above ground level.

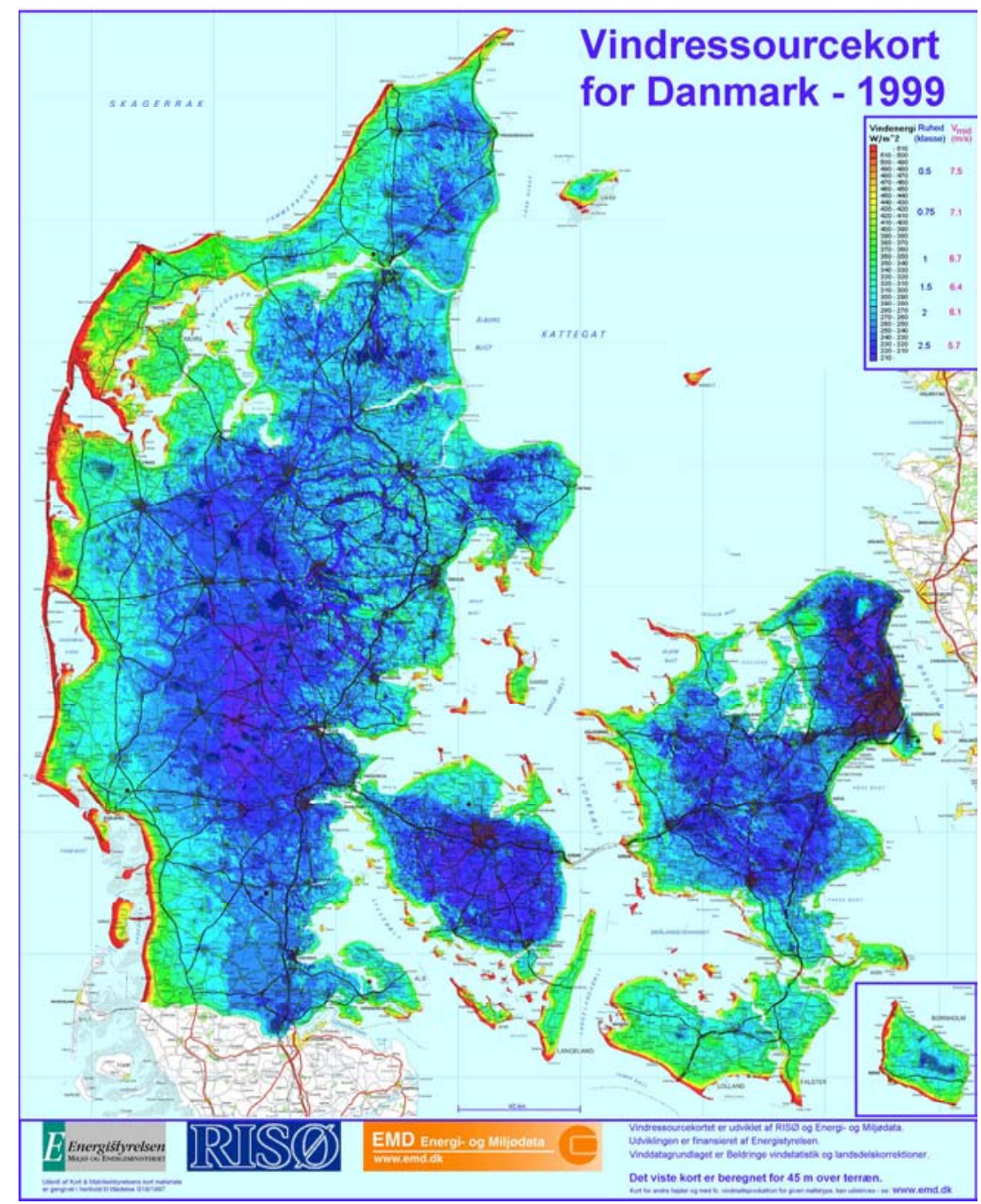

Figure 2 Wind resource map of Denmark from www.emd.dk.

A mean wind speed of $6.25 \mathrm{~m} / \mathrm{s}$ at 10 meters above ground level corresponds to a reasonable Danish site, see Figure 2. The comparison is, however, not straightforward since the terrain and roughness at the Sarfannguaq site is different from a Danish site, but should only be taken as rough guideline. 
More detailed statistics from www.winddata.com are shown in Figures 3-7.

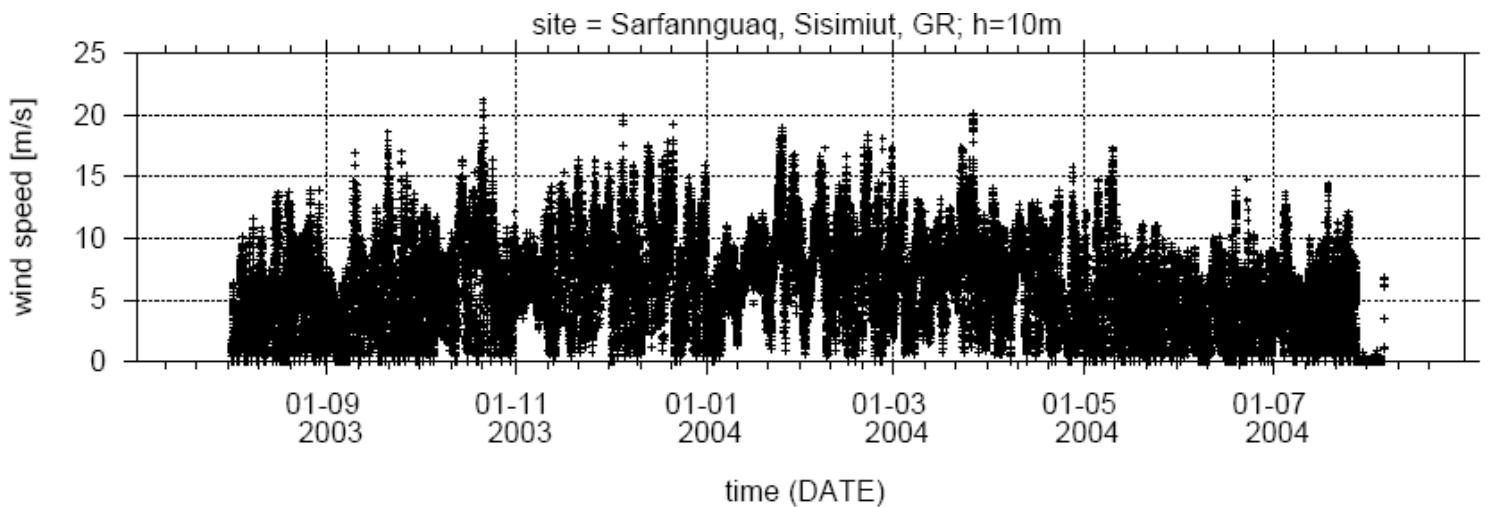

Figure 3 Time history of measured wind speed. Each dot represents the average over 10 minutes.

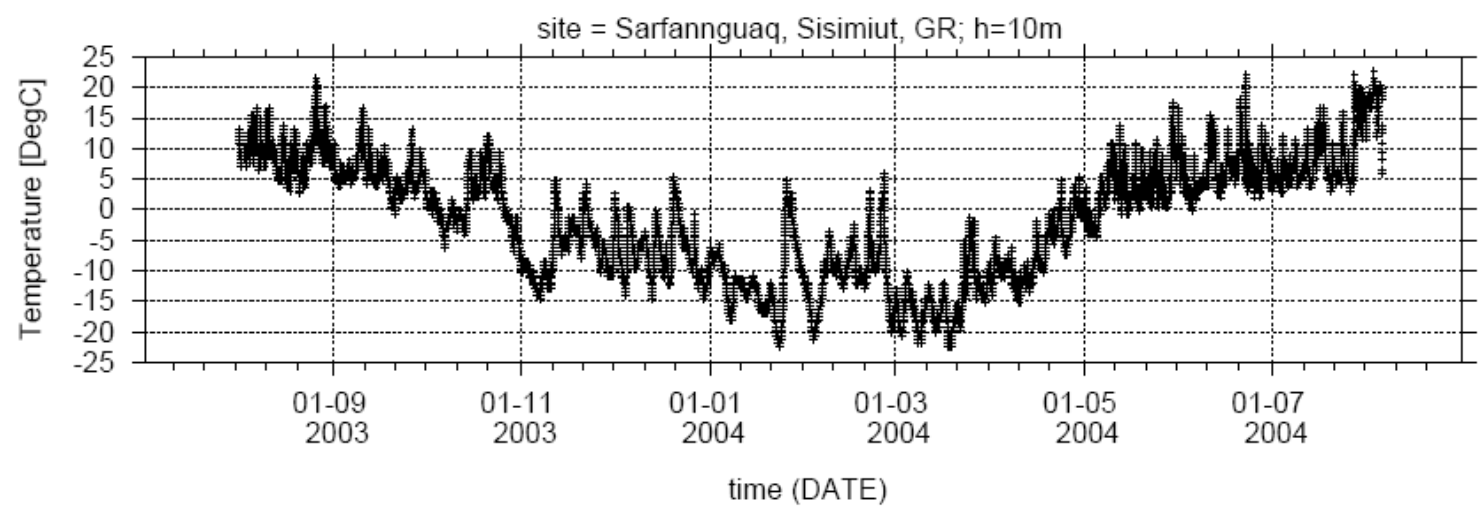

Figure 4 Time history of measured temperature.

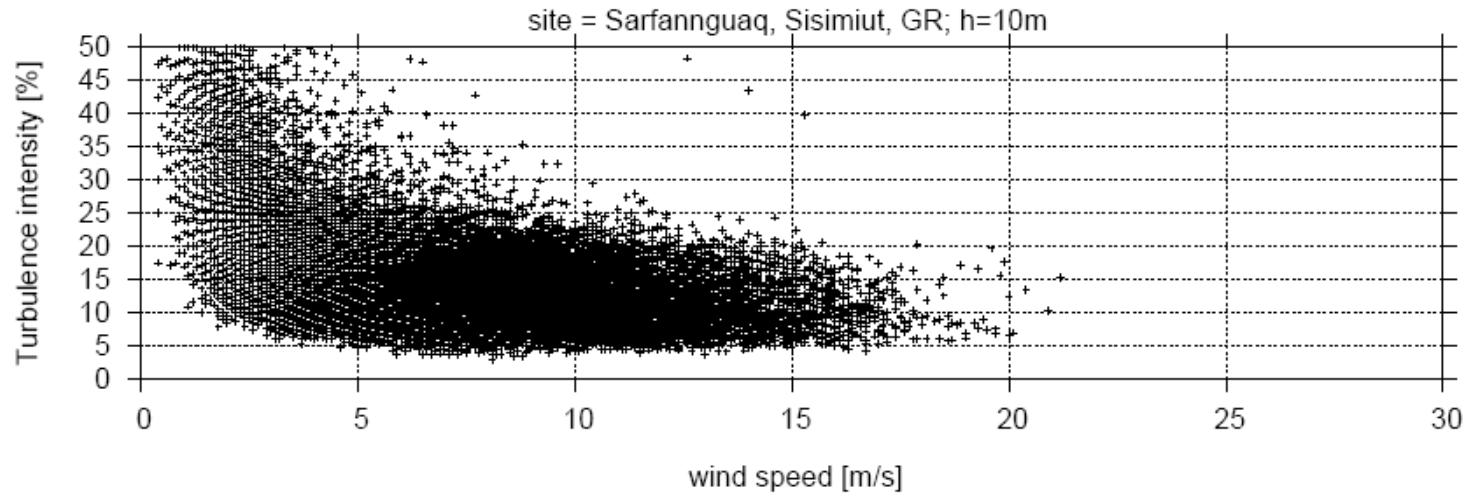

Figure 5 The turbulence intensity as a function of wind speed. 


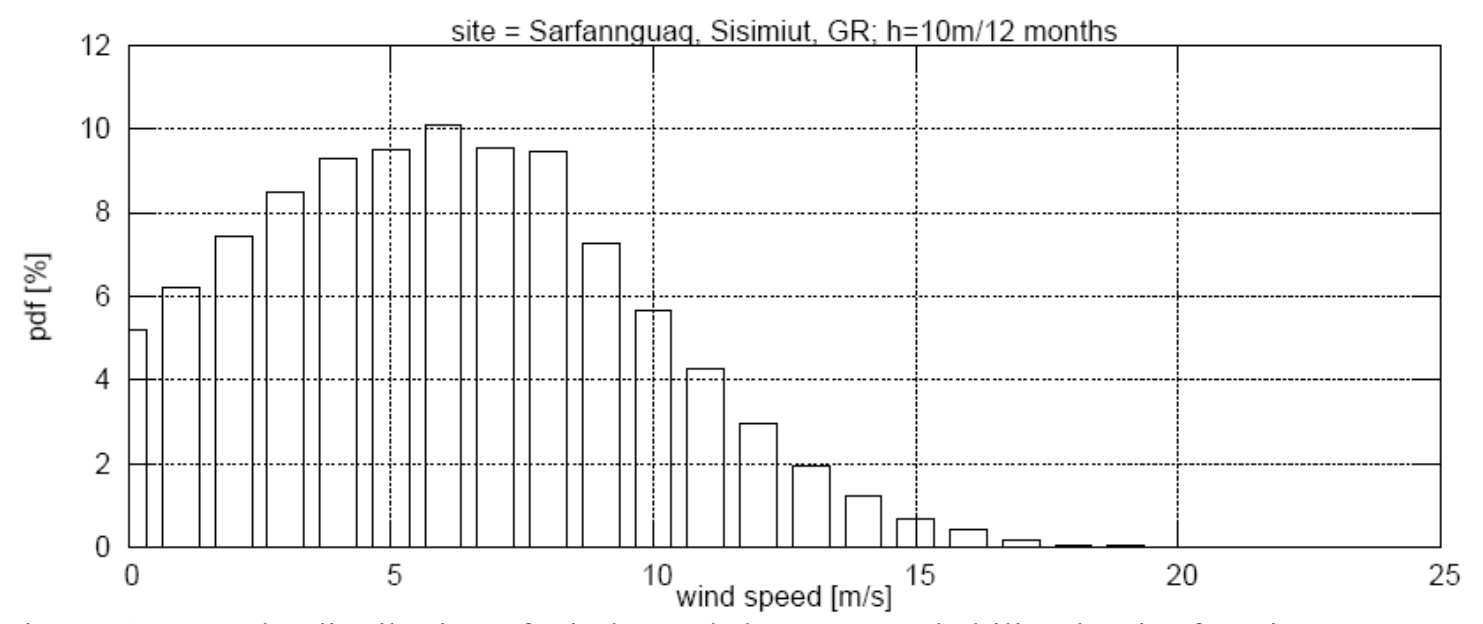

Figure 6 The distribution of wind speed shown as probability density function.

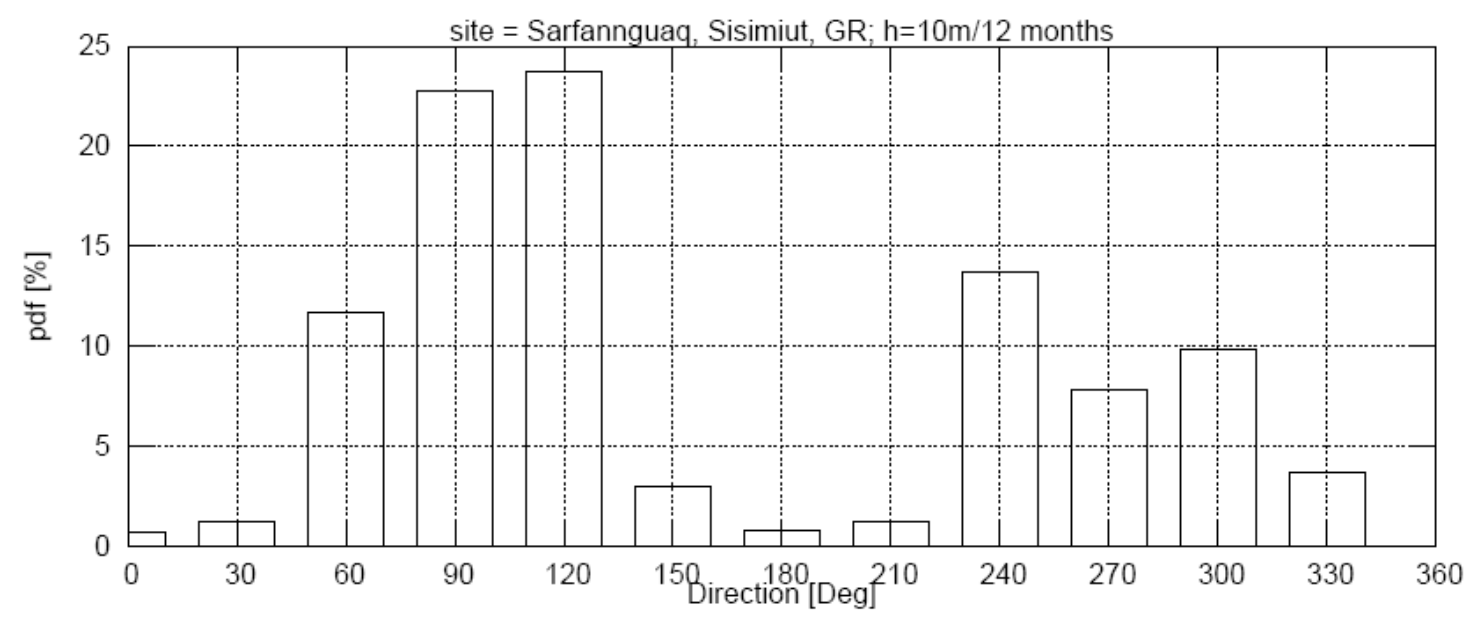

Figure 7 The distribution of wind direction shown as probability density function.

Figure 3 shows the measured time history of the wind speed, while Figure 6 shows the probability density function of the wind speed. It is noted that no wind speed above $25 \mathrm{~m} / \mathrm{s}$ was recorded in the period, indicating that a wind turbine located at near Sarfannguaq would not have been shut down for storm protection in this year. Figure 7 clearly shows that the dominant wind direction is either east (90 deg.) or west (270 deg.). This is probably because the wind is channelled by the hills/mountains along the fiord. Figure 5 indicates that the turbulence intensity is not very high compared to Danish sites, even though the terrain is quite rough as seen in Figure 1. This can be explained by the fact that the wind from the predominant directions comes from areas covered by water. The wind measurements near Sarfannguaq indicate some potential, although the size of a wind turbine must be chosen to match the consumption, which in Sarfannguaq is low due to the low number of inhabitants.

\section{REFLECTIONS REGARDING WIND ENERGY IN GREENLAND}

In Greenland there is no big electrical grid connecting the different societies, and therefore electricity is produced locally often using diesel generators. An advantage of supplementing with wind is to reduce the fuel consumption, which will make the villages less dependent on imported fuel. Further savings of fossil fuel also means less pollution, which might be an 
issue in ecological sensitive areas such as national parks. The problem with wind power is that it is intermittent, and the diesel motor has to be regulated to match the production from the wind turbine(s). Diesel motors for electricity production is optimised for one operational point and the efficiency when leaving this point is often poor. It would be better if the energy from the wind turbine(s) could be stored and used when e.g. the diesel motor is stopped. Batteries are still too expensive, but in the future the power could be used to produce hydrogen for fuel cells, which then could produce heat and electricity. In the latter case the diesel motor can be used for backup only. Using the wind turbine power to pump water to a high reservoir that can later be used to produce hydro electric power is another possible construction, but this system is probably still too expensive at the current price of diesel. Two more options exist that may presently be more economical attractive. The first option is to use wind turbines to produce drinking water from a desalination process, which requires much energy since water has to be pumped through membranes with a very high pressure drop. In this way drinking water is produced when there is wind and accumulated for later use. Presently drinking water is produced using desalination process at e.g. Itteleq, but not using wind power. The second option is to use wind turbines to supply the cold-storage plants used in the fishing industry, since the time constants to warm up these are quite large due to the insulation. That the wind turbine is stopped for some time because of low is therefore not critical. However, such an arrangement would still require a power backup system.

\section{CONCLUSION}

One year of wind measurements from Sarfannguaq indicates that there is sufficient wind resources available for erecting a wind turbine. However, the size of the wind turbine should be fitted with the local consumption of approximately 120 people and the turbine should be integrated with the diesel system currently used. Almost any modern commercial wind turbine is too big for this low consumption and the integration with a diesel system is not trivial. With today's relative low cost of diesel it may not be economical interesting to erect a wind turbine at Sarfannguaq. However, the measurements indicate that the wind resources in Greenland might not be as bad as sometimes postulated. The meteorological mast has been moved to a site in Sisimiut, where locals claim it is often windy. Measurements have been made here since August 2004, but has not yet been analysed. In the future where fuel cells become cheaper and more reliable it would be very natural to locally produce hydrogen using wind power and use this to produce heat and electricity instead of the traditional diesel plants. Presently it is suggested to use wind turbines to produce drinking water in connection with existing desalination plants and to drive the refrigeration systems on cold-storage plants for the fishing industry.

\section{REFERENCES}

[1] Henrik S.Iversen and Jakob S.Kristensen, "Vindresourcer i Grønland", student report of 11422 Arktisk teknologi, DTU, 2003. 


\title{
Individual heat metering attitudes to consumption of resources
}

\author{
Heinrich Nykjær Nielsen, Brunata a/s, E-mail: hnn@brunata.dk
}

\begin{abstract}
Individual heat metering has become a significant element in the increased efforts on achieving resource savings. In Denmark, individual heat metering at all consumers with common heat production has been obligatory since 1999. In Greenland, however, individual heat metering is not obligatory. Thus, together with the housing association INI in Sisimiut, in 2002 Brunata a/s initiated a test project on individual heat metering. The test project included two (almost identical) residential buildings. In building A, 33 flats were equipped with energy meters as well as hot water and cold water meters. Building B also consisted of 33 flats, but here no metering devises were installed in the flats. Subsequently, the consumption of the two buildings was monitored closely and the conclusion is clear. Making people aware of their own influence on their consumption is indeed an important element when wanting to achieve resource savings.
\end{abstract}

\section{THE INFLUENCE OF OBLIGATORY METERING ON HEAT CONSUMPTION}

A primary precondition for reducing the consumption of resources used for heating is of course the physical construction/insulation of the building as well as technical installations.

In buildings with multiple residents (for instance apartment houses) and common heat production in which consumption is allocated collectively on the basis of size (i.e. $\mathrm{m}^{2}$ ) individual consumers are not familiar with their own personal consumption and thus they have not incentive to reduce their consumption of heat. No matter what other energy saving measures have been implemented this will invariably lead to over-consumption - and as with heating this is also the case for the consumption of hot and cold utility water, electricity etc.

By introducing individual consumption metering and cost allocation the individual consumers are able to "monitor" their own consumption and this has a positive effect on both attitude and (bad) consumption habits. Put simply, paying only for ones personal consumption is an incentive to cut down on the consumption of heat, water etc.

An example (individual heat metering not implemented):

If you live in a residential building with 50 flats of $80 \mathrm{~m}^{2}$ each and you reduce your consumption by $20 \%$, you personally obtain only a reduction of $0.4 \%$.

As it will appear from this paper introducing individual heat metering leads to reductions in the total heat consumption of $15-35 \%$; and the very same tendency holds for individual recording and allocation of utility water and electricity consumption.

The below diagram clearly illustrates the connection between individual heat metering and reductions in the consumption of heat (not corrected for degree days).

During 11 years Brunata a/s followed the development in the buildings "Terrassehaven" in the Danish city of Næstved. Terrassehaven consists of 6 buildings with a total of 324 flats. 


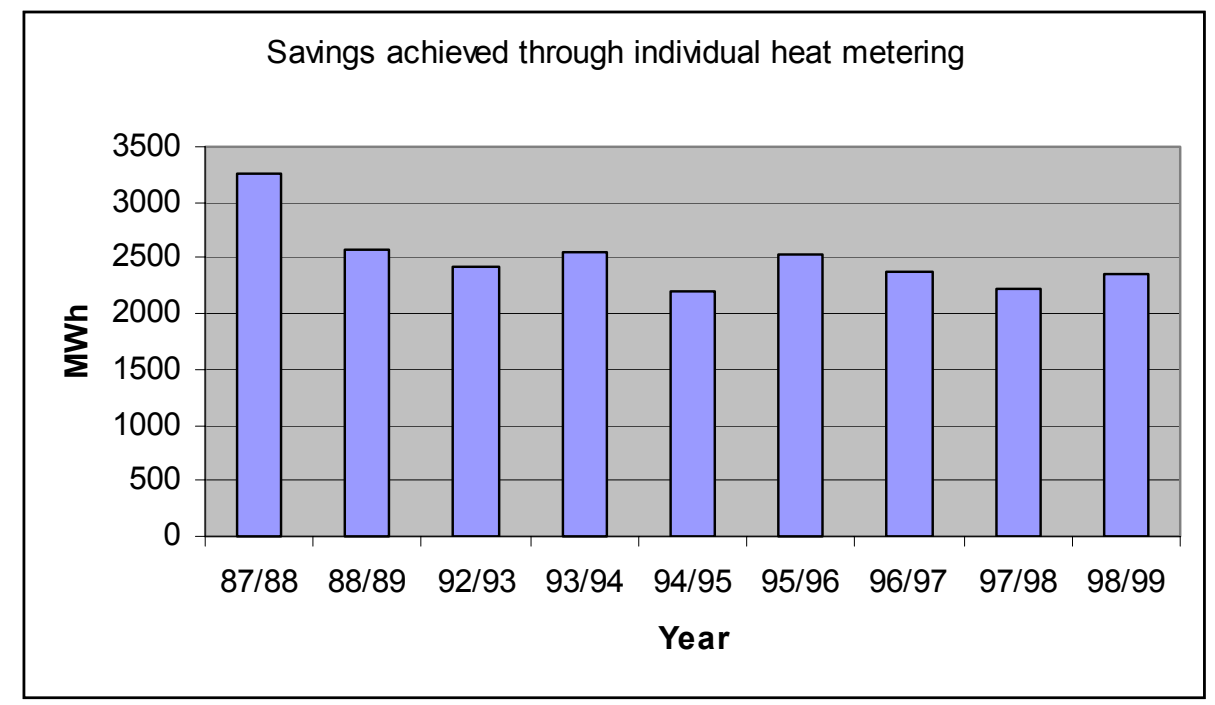

Figure 1 Savings achieved through individual heat metering during a period of 11 years.

As can be seen from the above, the saving is maintained during 11 years. The saving in $1998 / 99$ in proportion to $1987 / 88$ equals $28 \%$.

\section{THE TEST PROJECT IN SISIMIUT}

By an unanimous passing in the Danish Folketing in 1995, the Danish Act on individual heat metering at all consumers with common heat production was introduced - this goes for both residential and non-residential buildings. Before the passing of the Act on individual heat metering, $40 \%$ of the buildings affected had introduced individual heat metering voluntarily and the Danish authorities realised that if installed in the remaining $60 \%$ the consumption of heat could be reduced further. In Greenland, individual heat metering is not obligatory. Thus, in January 2002 Brunata initiated a cooperation with the Greenland housing association INI in Sisimiut. INI had been granted funds for the establishment of a test project involving individual heat metering in a residential building.

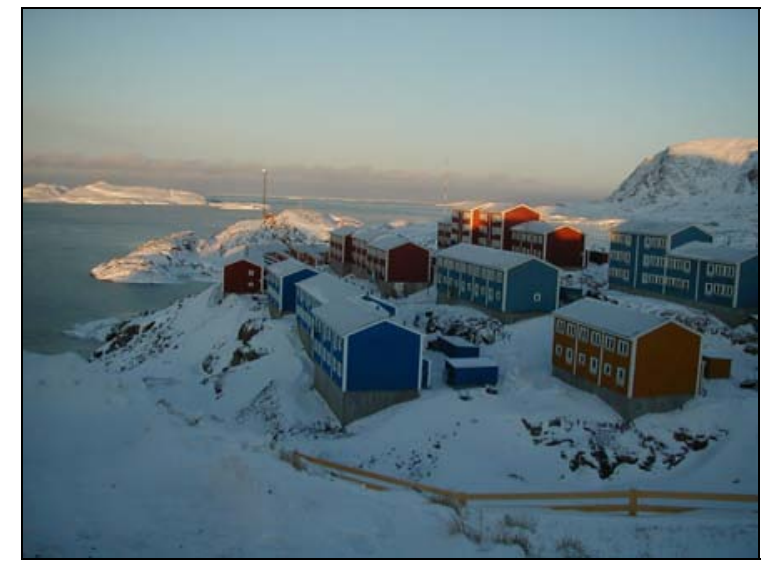

Figure 2 Division 265, the housing association INI, including the apartment houses used for the test project 
For this purpose two (almost identical) adjoining buildings were selected:

Building A: Individual metering

33 flats, each equipped with an energy meter for central recording of heat consumption as well as meters for hot and cold utility water. Furthermore, the main meters for district heating (separate energy meter on both heat and hot water production) as well as the main meter for cold utility water and a submeter on the cold water inlet for the hot-water tank were installed/replaced.

Building B: Reference building

No meters were installed inside the flats, but main meters similar to the ones of building A were installed/replaced.

\section{Metering equipment included in the test project:}

\section{3 flats (Building A)}

Heat: Brunata HGQ1-R0-180, electronic energy meter with Mbus interface

Hot water: ETX-K10-V, mechanical single-jet meter with pulse generator, Qn $1.5 \mathrm{~m}^{3} / \mathrm{h}$

Cold water: ETX-K10-K, mechanical single-jet meter with pulse generator, Qn $1.5 \mathrm{~m}^{3} / \mathrm{h}$

Building A

\& B: $\quad$ District heating, heat - HGS9-R4-184, electronic energy meter with Mbus interface

District heating, hot water - HGQ3-R4-184, electronic energy meter with Mbus interface

Cold water - MNR-K10-K, mechanical multi-jet meter with pulse generator Qn $10.0 \mathrm{~m}^{3} / \mathrm{h}$

Hot water production - MNR-K10-K, mechanical multi-jet meter with pulse generator $6.0 \mathrm{~m}^{3} / \mathrm{h}$.
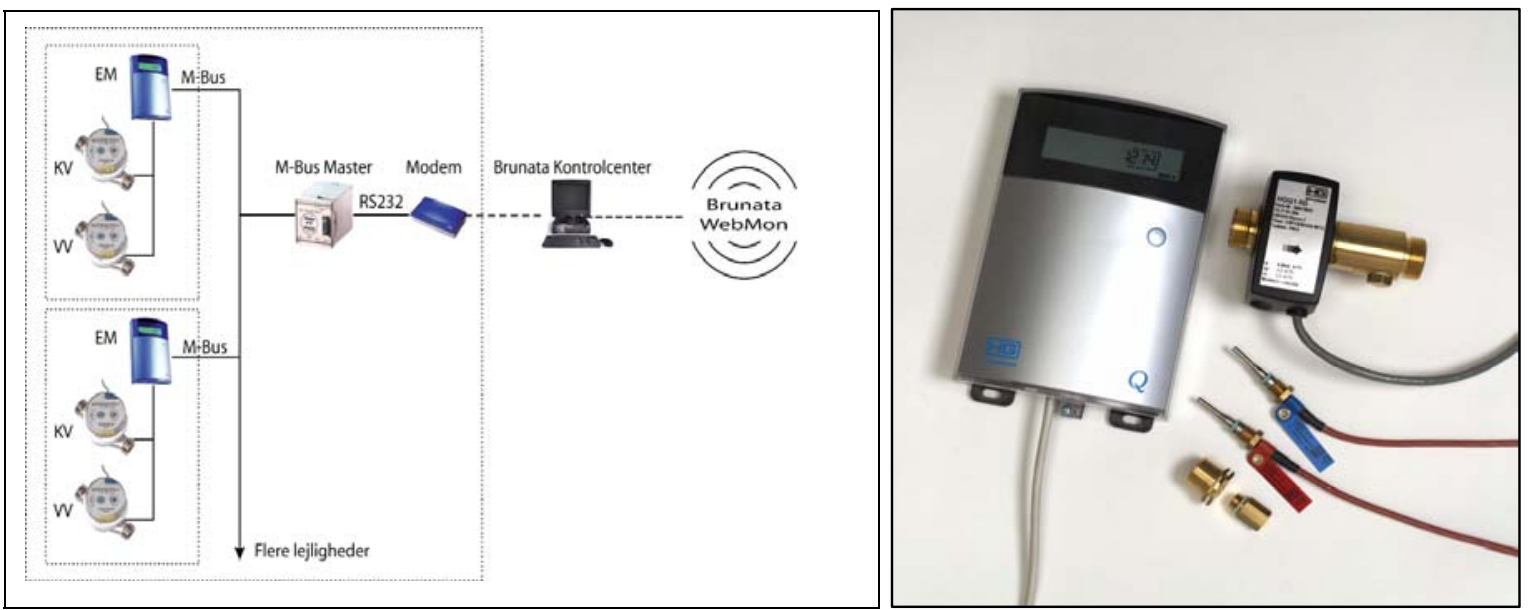

Figure 3 Flow chart (left hand side), HGQ display in flat (right hand side)

Energy meters, also functioning as pulse counters and display for the mechanical water meters, were connected to a 2-thread MBus Master in each building. Metering data were transferred by remote reading to Brunata's headquarters in Copenhagen. 
The system was put into operation on 1 August 2003 and was read every month using remote reading. During some periods the system was read every 24 hours.

The below table (Table 1) contains the reading results of the consumption of the buildings A and $\mathrm{B}$; as it can be seen consumption in building A (individual heat metering) is somewhat lower than in building B.

Table $1 \quad$ Total consumption and reductions 2004

\begin{tabular}{llrrr}
\hline & \multicolumn{2}{c}{ Heat/hot water } & Hot water & Cold water \\
{$[\mathrm{MWh}]$} & & $\begin{array}{c}\left.\mathrm{m}^{3}\right] \\
{\left[\mathrm{m}^{3}\right]}\end{array}$ \\
\hline Building A: & Heat & 396.136 & $1,244.64$ & $1,777.00$ \\
& Hot water & 106.261 & & $2,519.39$ \\
\hline Building B: & Heat & 489.170 & $1,910.65$ & \\
(reference) & Hot water & 136.232 & & \\
\hline Reduction in units & Heat & 93.034 & & \\
& Hot water & 29.971 & & \\
\hline & Total & 123.005 & & \\
\hline Reduction in \% & Heat & $19.02 \%$ & & $29.47 \%$ \\
\hline & Hot water & $22.00 \%$ & $34.86 \%$ & \\
\hline
\end{tabular}

Before initialising the project individual consumption metering was not possible according to the rules existing in Greenland. Thus, the objective of the test project was to document to the Greenland Home Rule Authority the positive effects of implementing individual metering.

The fact that consumers were not invoiced on the basis of the individual readings made the test project slightly difficult. However, at the beginning of the project the residents were informed of the purpose (and importance) of the project. Subsequently, this rule has in fact been modified by the Greenland Home Rule Authority and now the residents in building A are invoiced on the basis of individual readings. The first invoices are not yet available, but consumption is expected to be reduced even further once the residents receive their bills.

\section{Differences in consumption}

The reduction in consumption is let alone based on the fact that all unnecessary consumption is eliminated. The comfort is the same, but as illustrated in table 2 below there are large differences in the individual residents' need for heat and water. 
Table 2 Differences in consumption per $\mathrm{m}^{2} /$ per year

\begin{tabular}{lccrrrr}
\hline & $\begin{array}{c}\text { Heat } \\
{\left[\mathrm{kWh} / \mathrm{m}^{2}\right]}\end{array}$ & $\begin{array}{c}-/+ \\
\%\end{array}$ & $\begin{array}{c}\text { Hot water } \\
{\left[1 / \mathrm{m}^{2}\right]}\end{array}$ & $\begin{array}{c}-/+ \\
\%\end{array}$ & $\begin{array}{c}\text { Cold water } \\
{\left[1 / \mathrm{m}^{2}\right]}\end{array}$ & $\begin{array}{c}-/+ \\
\%\end{array}$ \\
\hline Lowest & 41.619 & 26 & 48.52 & 8 & 90.53 & 10 \\
\hline $\begin{array}{l}\text { Second } \\
\text { lowest }\end{array}$ & 66.530 & 42 & 130.96 & 22 & 233.76 & 27 \\
\hline $\begin{array}{l}\text { Third } \\
\text { Lowest }\end{array}$ & 71.805 & 45 & 161.00 & 27 & 280.56 & 32 \\
\hline Average & 159.606 & 100 & 581.02 & 100 & 856.50 & 100 \\
\hline $\begin{array}{l}\text { Third } \\
\text { highest }\end{array}$ & 304.929 & 191 & $1,154.80$ & 198 & $1,611.03$ & 188 \\
\hline $\begin{array}{l}\text { Second } \\
\text { highest }\end{array}$ & 325.188 & 203 & $1,247.46$ & 214 & $1,722.89$ & 201 \\
\hline Highest & 325.996 & 204 & $1,573.08$ & 270 & $1,816.06$ & 212 \\
\hline
\end{tabular}

\section{CONCLUSION}

Introducing individual metering requires some initial investments. The price differs depending on the type of building, the technical installations, the number of meters needed as well as requirements to for instance remote reading facilities. Typically, the price for heat metering lies between DKK 1,500-3,500 (EUR 200-466) per flat. The annual costs for reading and accounting amount to approx. DKK 150-250 (EUR 20-33) per flat. Naturally, installing a system based on remote reading requires further investments. However, the annual reading costs (operation) are then reduced by $30-40 \%$.

At a reduction in the total consumption of $20 \%$ corresponding to approx. DKK 2,000 (EUR 266) per flat, the investment is profitable already after 1-2 years. Thus, introducing individual heat metering unquestionably pays off - both economically and environmentally.

About Brunata a/s

For more than 85 years Brunata a/s has produced and sold metering solutions for individual billing of costs for heating, utility water, electricity etc. In Denmark, Brunata has 260 employees. On an annual basis we read and service 2.5-3 million meters and prepare allocation accounts for approx. 400.000 units (i.e. flats). Today, Brunata is represented in dozens of countries around the world either through business representatives or through our own subsidiaries which are found in countries such as Bulgaria, China, Croatia, Norway, Poland, Slovenia and Sweden. 


\section{Water, Heat and Power Supply of Houses in Greenland - the Next 25 Years}

Svend Ove Nielsen, Manager for Energy, Nukissiorfiit

The future developments of the expected consumptions of power and water will be discussed together with an evaluation of the possible options for combining the energy supply for dwellings. Furthermore there will be spoken of renewable energy - such as hydropower, hydrogen, solar, wind etc. 


\title{
How shall we Build and Live in the Arctic in the Future
}

\author{
Erik Grundtvig, Architect.
}

\section{AN ARCTIC TECHNOLOGI IS DEVELOPED}

'In the 1950'ies GTO was almost the only one to cover the needs for the technical development. In the beginning there was a little knowledge about which technical solutions there should be applied under arctic conditions. There were not many experiences to get from other countries and cold regions.

Engineers and architects have in the arctic areas - independent of each others - developed a special technology and they have applied and adapted technology which has been developed under warmer climate. One has paid the same amount of money. One has had the same typical damages and the solution one has reached is surprisingly alike.

In all the countries on the Northern Cap we have amongst others got to demolish new buildings, where the cracking because of subsidence were too fierce, because we did not yet master the perm-frost-technique.

The establishment of hole-year water-supply, frost-securing of water and drain pipes, and the equipment of fire service which is workable under severe frost, also demands a very advanced technology.

Harbour-constructions and bitts have to resist the ice pressure.

In all details - in roofs, walls, windows, outer-doors etc. - the building constructions have to not only resist the frost, but also storms, snow and heavy rain.'

By Gunnar P Rosendahl, Grønland

In my studies I saw a project by Ralph Erskine on building in Arctic.

The houses turned the back towards north, the cold wind, and made a shield as a ring of chariots, this was one of the first projects I saw, that had a vision.

Some places in Arctic there are made a building envelope above a building, so you do not have to go out to visit the neighbour or the shop. This is also a vision for how to build and live in Arctic, here you do not have to go out in the extreme weather it sometimes is.

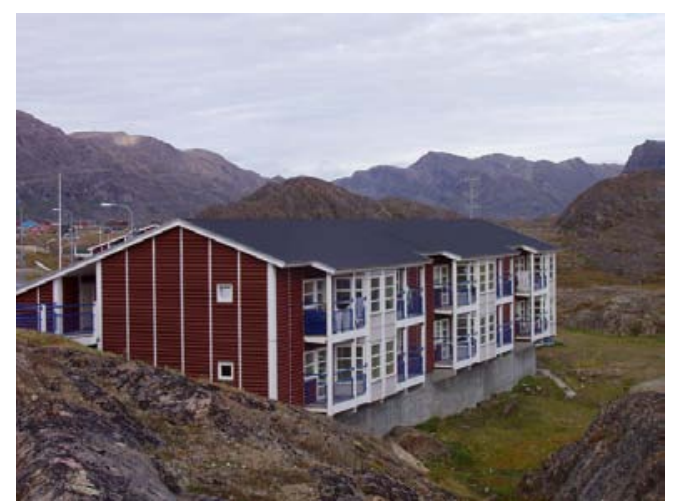

Residence for elderly people in Sisimiut

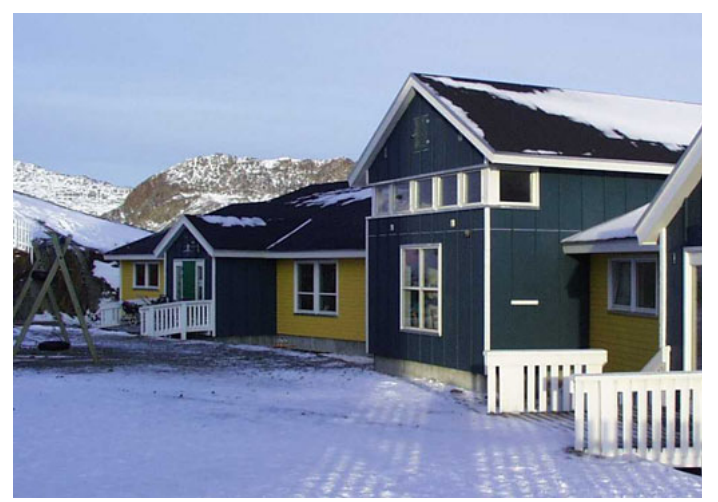

Kindergarten in Sisimiut 
In Greenland there is no tradition for collecting the buildings under one roof. The nature means a lot for the inhabitants and the weather does not seem so discouraging. It is therefore common that you are outside.

Do you ask yourself how we shall build and live in the future then we have to ask the infrastructure.

National planning, municipal planning, the size of the towns and settlements.

For a town like Sisimiut it is therefore very important to have clarified the relations to the Kangerlussuaq airport and the road that has to run between Sisimiut and Kangerlussuaq.

These relations will have a huge impact on how we will settle in the area. There will now be a huge free area between Kangerslussuaq and Sisimiut, also will a settlement like Sarfanquaq have a future, because it is placed in the middle of the distance.

An important factor for the whole structure in Greenland is how many centres there are going to be on the western coast, and how the relation to the eastern coast will be in the future.

Would it be possible to place a big Atlantic-airport in Kangerslussuaq which would service the whole Greenland and a smaller one in Nuuk, or do all the centres need to be moved to Nuuk - and how will the structure be then?

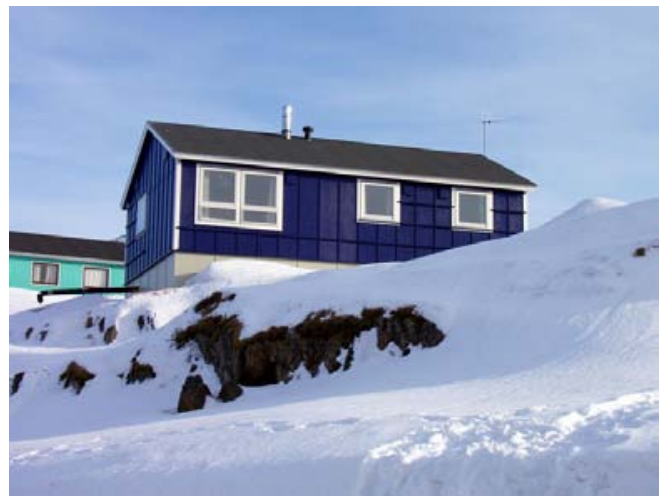

Illorput 2000

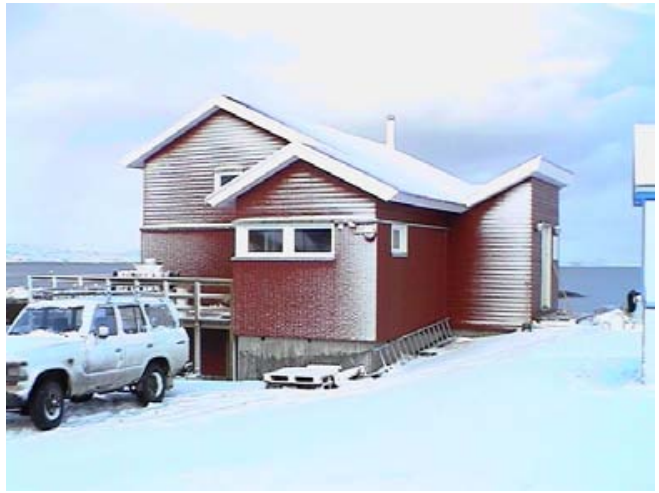

One-Family House

My starting point will be the Illorput, the house built with own hands. The house has existed for many years on Greenland and it is currently developed with new types, which have the aim to make it easier for the dweller to build the house.

Today we are working on a new construction, which gives a highly insulated house in a Kerto-frame-construction with minimal thermal bridge and $300 \mathrm{~mm}$ insulation in walls and roofs, and $250 \mathrm{~mm}$ in floor.

In small-house-buildings 'close low etc' can one use something like Kerto-frameconstructions or slitted light-weight-profiles, which we consider as having many advantages. It gives a huge freedom with regards to arrangement, because with a frame-construction one does not need to have stabilised internal walls. There are also energy-advantages by minimizing the use of materials: Saw-cut wood in Greenland decreases a lot in the dry air and this has often given problems with draught in the centre-points. 


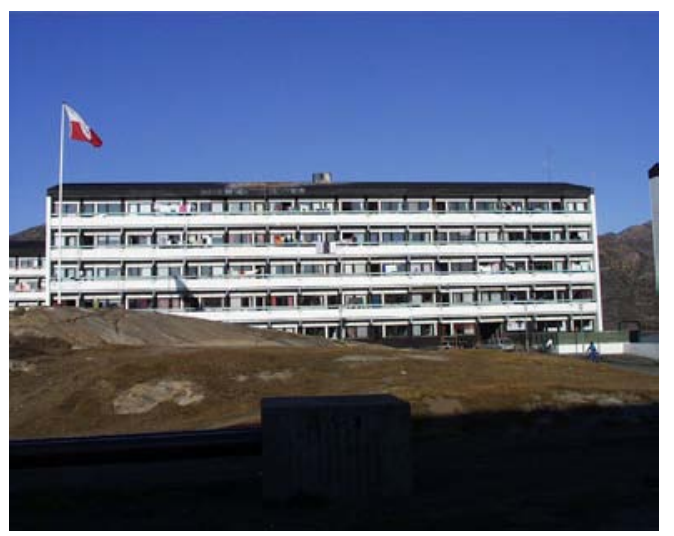

Block in Sisimiut

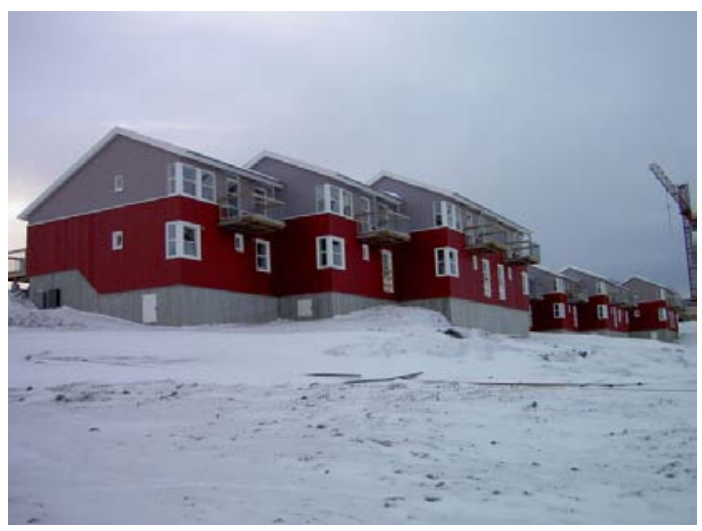

Terraced houses in Sisimiut

Additional insulation of the houses should also be done, and this will also be relevant once the new building regulation is made.

Because a product as Kerto is form-stable it will not dry-in and thereby give draught between the building components, which is a very important factor for the heat loss. Draught also gives a bad indoor climate.

In larger buildings there are advantages by using concrete. The material is strong. Stone, gravel and water are up here and the product is fire-safe.

Steel is another possibility for the future buildings. With advantage we can learn from America where they have many years of experience with this material.

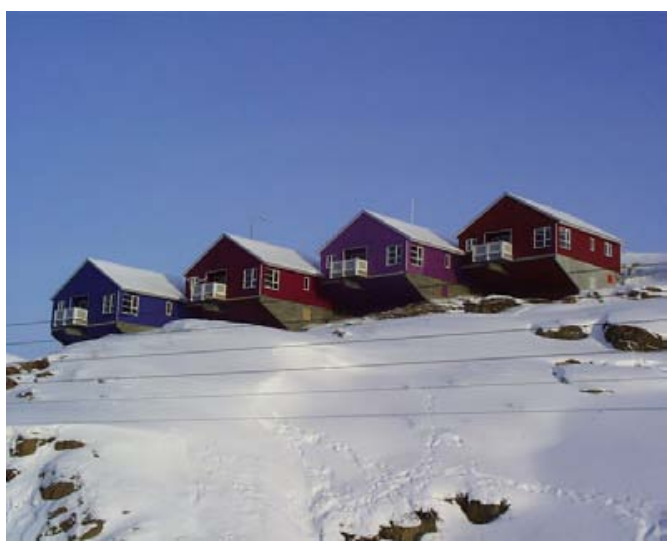

Share-departments in Sisimiut

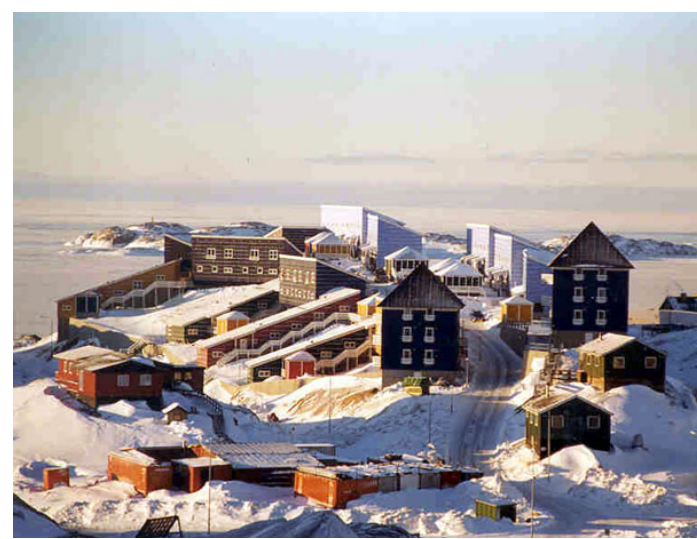

Dwelling-area in Sisimiut

The first apartment houses were built with load bearing apartment boundaries and floors in concrete.

The construction is good enough were the concrete is covered, but it has to be shielded by a building envelope. We see this at the balcony-aisles and at the cantilevers which gets moisture and frost-damages.

A renovation of those old apartment houses can be done by changing the light façade with new modern ones, as well as adjust the arrangements where there are light walls. Moreover there has to be done something about the balcony-aisles.

There is also one question concerning Greenland's Building Regulation. The regulation is soon 25 years old and it can be a problem to get new modern buildings because the building owner wants to save money. 
The residence itself has not changed a lot for the last 30 years. The apartments have become larger, but else like the arrangements are the same.

A relatively new issue in Greenland is the share-department where there is a possibility to collect a number of houses in enclaves. Experiences have in the meantime shown that dwellers rather will have their own detached house and will only have the relation to others because of the economy.

The prosperity is a must when we talk about the dwelling in the future.

Prosperity in the dwelling concerns the arrangement, the view, being together with the neighbour, a good indoor climate and the areas between the houses.

Moreover there preferably has to be something exciting visually to look at and be in.

An essential factor to prosperity is flexibility according to the arrangement of the dwelling. The dwellers must have the possibility to be more concurrent in the way they want to live.

- The future dwelling has a small energy-consumption, '0-energy-house'.

- The future dwelling could be an enclave of 'close low'-buildings, where there were possibilities for different arrangements, without planning different houses.

- The future dwelling could also be apartments in a tower block with possibilities for different arrangements by the first tenant and the following tenants. In a tower block you have to be aware of the outdoor rooms which are not there, and to get the common areas inside the house.

- The future dwelling can be placed in extreme places, where wind- and snowinfluences makes it necessary to verify the shapes of the building so there is as little wind-resistance and snow-accumulation as possible.

- The future dwelling will outside the towns, where there is no real energy-source, be heated and get electricity from the sun, wind and water, this could for example be a good idea in the settlements and outside the towns.

- In the towns it will be energy by water-power that will be the bearing part.

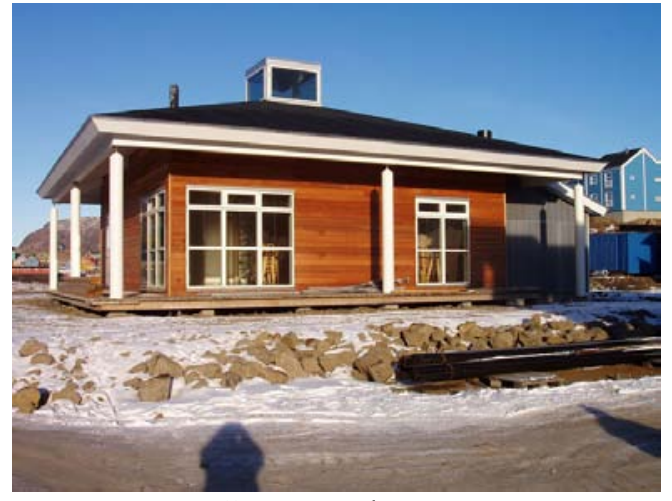

Common house

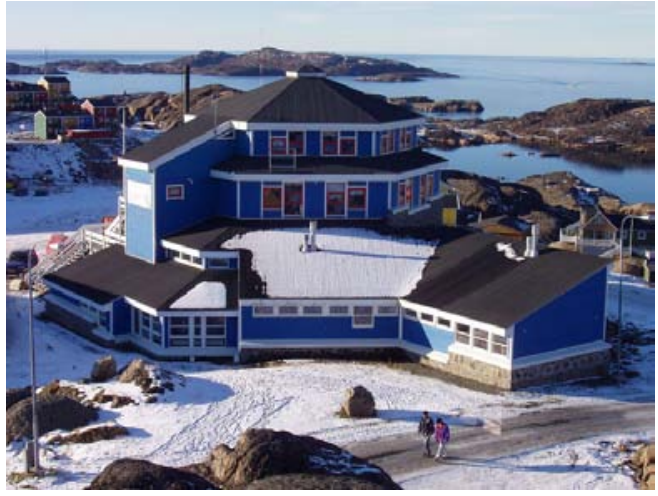

Language school 


\section{centertor}

\section{ARKTISK TEKNOLOGI}

www.arktiskcenter.gl

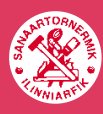

Sanaartornermik llinniarfik Box 1001, 3911 Sisimiut

Greenland

Tel: $\quad(+299) 864488$

Fax: (+299) 864528

E-mail:artek@sanilin.gl

\section{$\stackrel{010}{\Xi}$}

Danmarks Tekniske Universitet / Technical University of Denmark Kemitorvet, Building 204, DK-2800 Kgs. Lyngby

Denmark

Tel: $(+45) 45252163$ / 45252165

Fax: $(+45) 45885935$

E-mail: artek@byg.dtu.dk 